\title{
STREAMFLOW CHARACTERISTICS AT HYDROLOGIC BENCH-MARK STATIONS
}

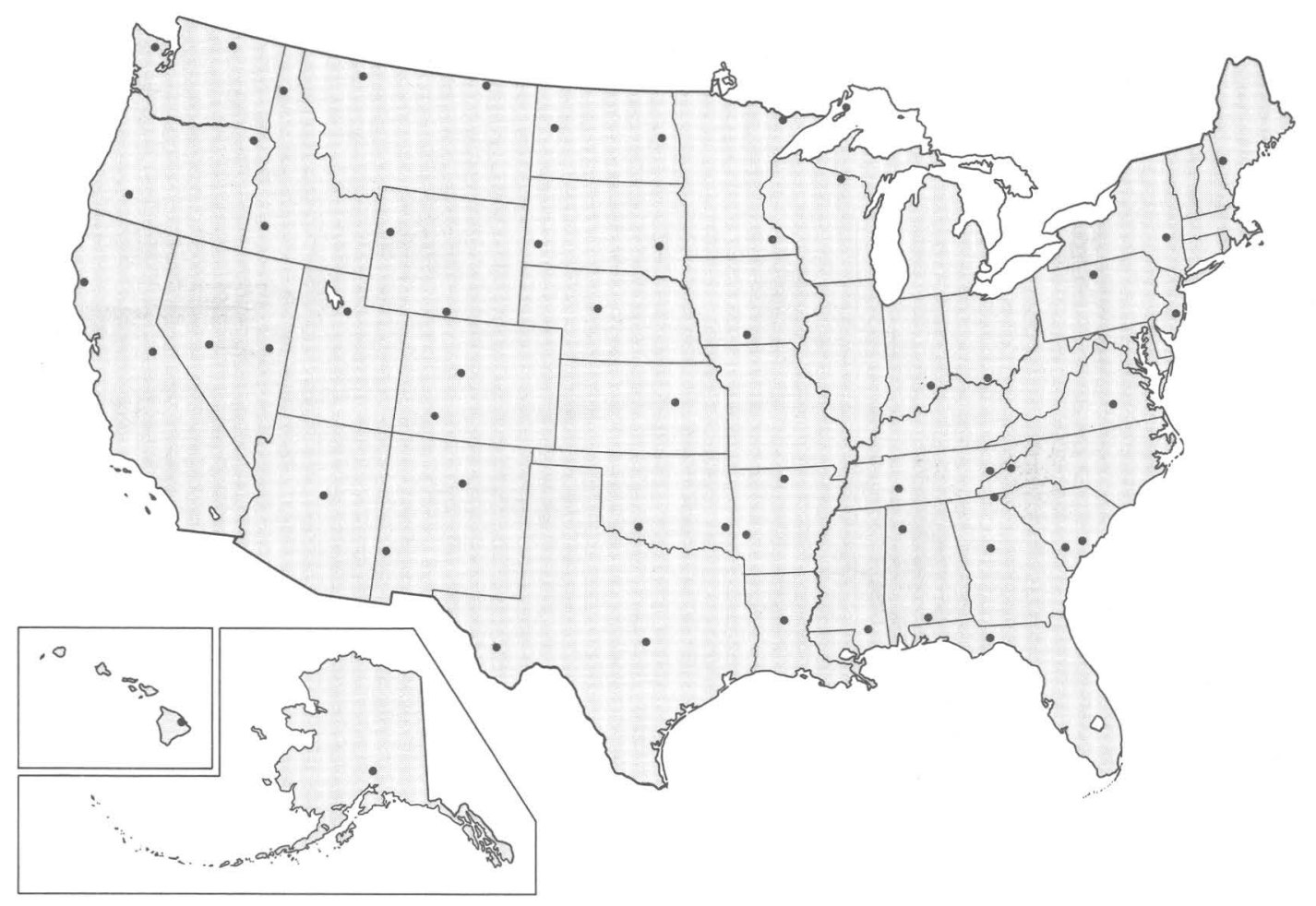





\title{
STREAMFLOW GHARACTERISTICS AT HYDROLOGIC BENCH-MARK STATIONS
}

\author{
By C. L. Lawrence
}

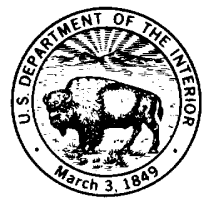

U.S. Geological Survey Circular 941 


\section{DEPARTMENT OF THE INTERIOR DONALD PAUL HODEL, Secretary \\ U.S. GEOLOGICAL SURVEY \\ Dallas L. Peck, Director}

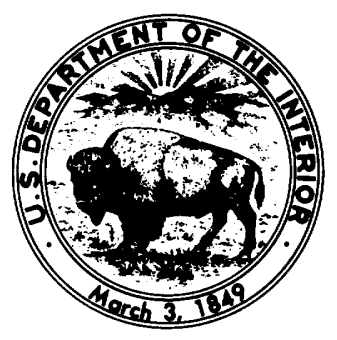

Free on application to the Books and Open-File Reports Section, U.S. Geological Survey, Federal Center, Box 25425, Denver, CO 80225 


\section{CONTENTS}

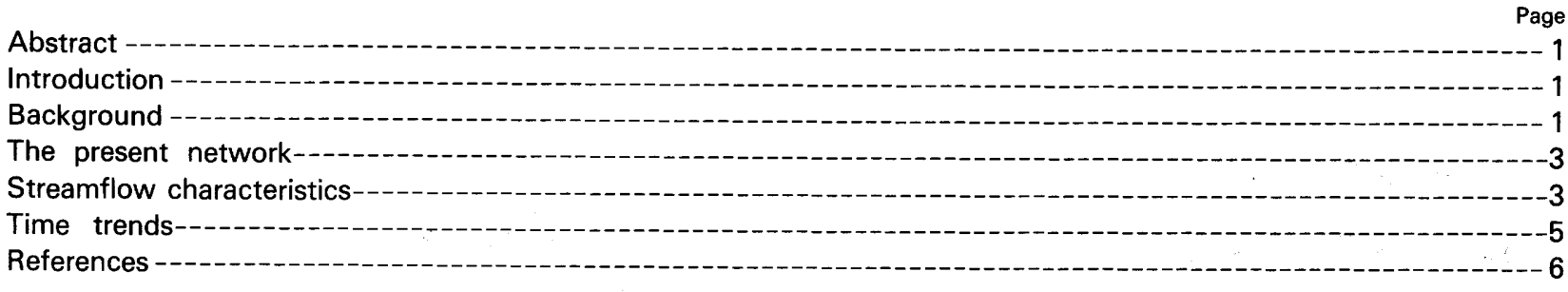

\section{ILLUSTRATION}

Figure 1. Map showing location of hydrologic bench-mark stations-

Stations 1-58. Streamflow characteristics for:

\section{STATIONS}

1. Blackwater River near Bradley, AL-_-

2. Sipsey Fork near Grayson, AL-_

3. Talkeetna River near Talkeetna, AK-

4. Wet Bottom Creek near Childs, AZ-_-

5. Cossatot River near Vandervoort, AR-16

6. North Sylamore Creek near Fifty Six, AR-

7. Elder Creek near Branscomb, CA-_.

8. Merced River at Happy Isles Bridge near Yosemite, CA-_-_-

9. Halfmoon Creek near Malta, CO-_.

10. Vallecito Creek near Bayfield, $\mathrm{CO}$

11. Sopchoppy River near Sopchoppy, FL-

12. Falling Creek near Juliette, GA-

13. Tallulah River near Clayton, GA--

14. Honolii Stream near Papaikou, HI-_-

15. Big Jacks Creek near Bruneau, ID-_-

16. Hayden Creek below North Fork near Hayden Lake, ID-_-_.

17. South Hogan Creek near Dillsboro, IN-

18. Elk Creek near Decatur City, IA-_-

19. Kings Creek near Manhattan, KS-_-

20. Big Creek at Pollock, LA--

21. Wild River at Gilead, ME-_-

22. Washington Creek at Windigo, Isle Royale, MI-

23. Kawishiwi River near Ely, MN-_-

24. North Fork Whitewater River near Elba, MN-_-

25. Cypress Creek near Janice, MS-_-

26. Rock Creek below Horse Creek near International Boundary, MT-_-

27. Swift Current Creek at Many Glacier, MT-

28. Dismal River near Thedford, NE--

29. South Twin River near Round Mountain, NV-_-

30. Steptoe Creek near Ely, NV-_-

31. McDonalds Branch in Lebanon State Forest, $\mathrm{NJ}$

32. Mogollon Creek near Cliff, NM--

33. Rio Mora near Tererro, NM-_-

34. Esopus Creek at Shandaken, NY-_-

35. Cataloochee Creek near Cataloochee, NC-1

36. Bear Den Creek near Mandaree, ND-_-

37. Beaver Creek near Finley, ND-_-

38. Upper Twin Creek at McGaw, OH-_-

39. Blue Beaver Creek near Cache, OK- 


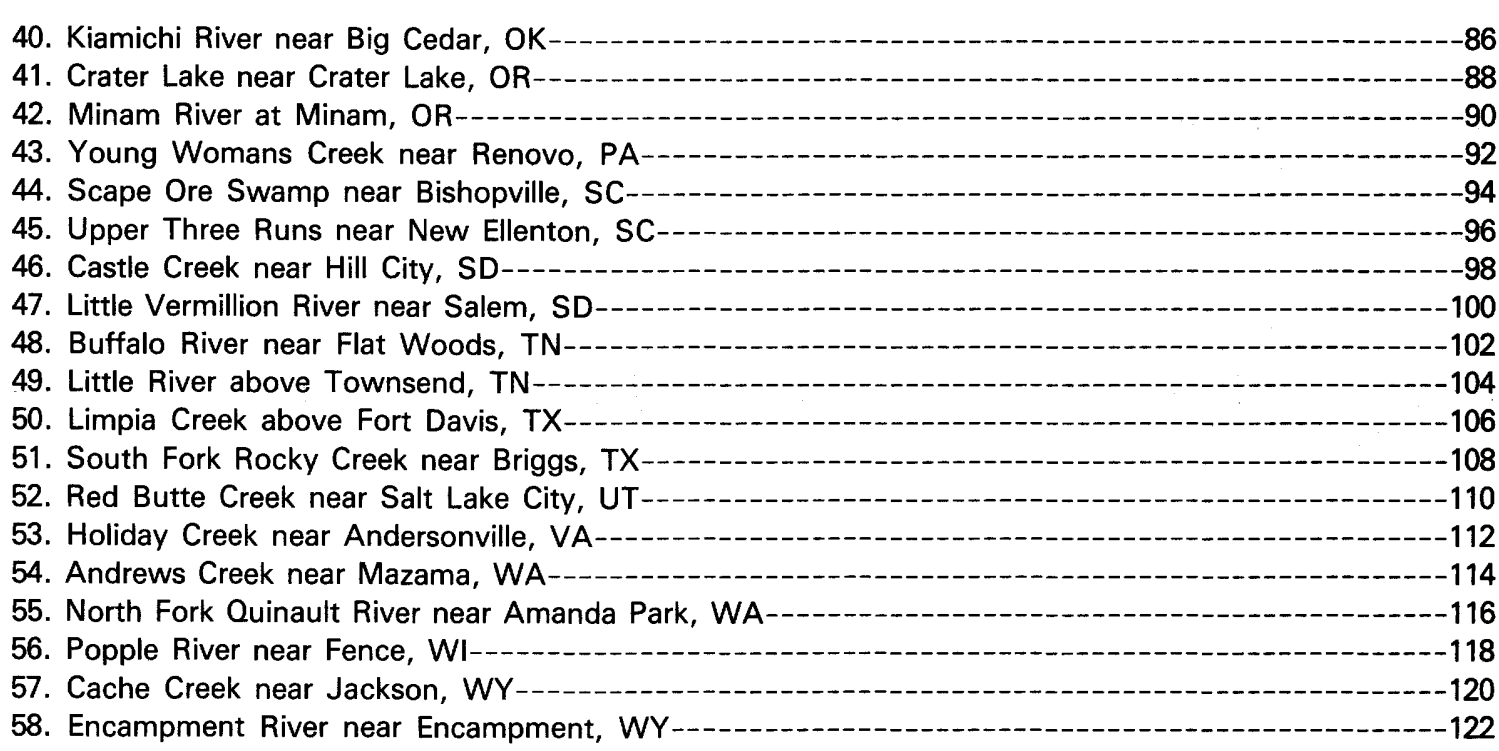




\section{CONVERSION TABLE}

For readers who prefer to use the International System of Units (SI) rather than inch-pound units, conversion factors for terms used in this report are listed below.
Multiply
By
To obtain
foot (ft)
0.3048
1.609
mile (mi)
0.02832
cubic foot per second $\left(\mathrm{ft}^{3} / \mathrm{s}\right)$
2.589
foot per mile ( $\mathrm{ft} / \mathrm{mi}$ )
0.1894
meter $(\mathrm{m})$
kilometer $(\mathrm{km})$
cubic meter per second $\left(\mathrm{cm}^{3} / \mathrm{s}\right)$
square kilometer $\left(\mathrm{km}^{2}\right)$
meter per kilometer $(\mathrm{m} / \mathrm{km})$





\section{STREAMFLOW CHARACTERISTICS AT HYDROLOGIC BENCH-MARK STATIONS}

By C. L. Lawrence

\section{ABSTRACT}

The Hydrologic Bench-Mark Network was established in the 1960's. Its objectives were to document the hydrologic characteristics of representative undeveloped watersheds nationwide and to provide a comparative base for studying the effects of man on the hydrologic environment. The network, which consists of 57 streamflow gaging stations and one lakestage station in 39 States, is planned for permanent operation.

This interim report describes streamflow characteristics at each bench-mark site and identifies time trends in annual streamflow that have occurred during the data-collection period.

The streamflow characteristics presented for each streamflow station are (1) flood and low-flow frequencies, (2) flow duration, (3) annual mean flow, and (4) the serial correlation coefficient for annual mean discharge. In addition, Kendall's tau is computed as an indicator of time trend in annual discharges. The period of record for most stations was 13 to 17 years, although several stations had longer periods of record. The longest period was 65 years for Merced River near Yosemite, Calif.

Records of flow at 6 of 57 streamflow sites in the network showed a statistically significant change in annual mean discharge over the period of record, based on computations of Kendall's tau. The values of Kendall's tau ranged from -0.533 to 0.648 . An examination of climatological records showed that changes in precipitation were most likely the cause for the change in annual mean discharge.

\section{INTRODUCTION}

Population and industrial growth have altered the Nation's environment. The effects of man's alteration of the environment are of particular concern with regard to the Nation's water resources, the efficient use of which is dependent on an understanding of the flow and quality of streams in the United States and their alteration by man's activities.

The purpose of this report is to present flow characteristics derived from streamflow records that were collected from a network of 57 streamflow gaging stations established on essentially unregulated streams across the Nation. These streams, which were selected because no changes from activities of man within their basins were foreseen, provide a base of surface-water data with which records from developing watersheds can be compared. In addition to developing a stable base of flow characteristics for use in comparisons, the base of characteristics itself was analyzed to identify trends in the flow that might exist and, if any were found, to determine their probable cause. This report also presents data collected at the single lake-stage station in the network.

\section{BACKGROUND}

The U.S. Geological Survey collects hydrologic data on about 7,000 streams throughout the United States. These data are collected, in part, for current use in many planning and management functions and for use in documenting natural changes in hydrologic characteristics over time. The data are collected on large and small streams and at sites where the flow is natural or controlled. Over a period of time, man's influences, especially those 


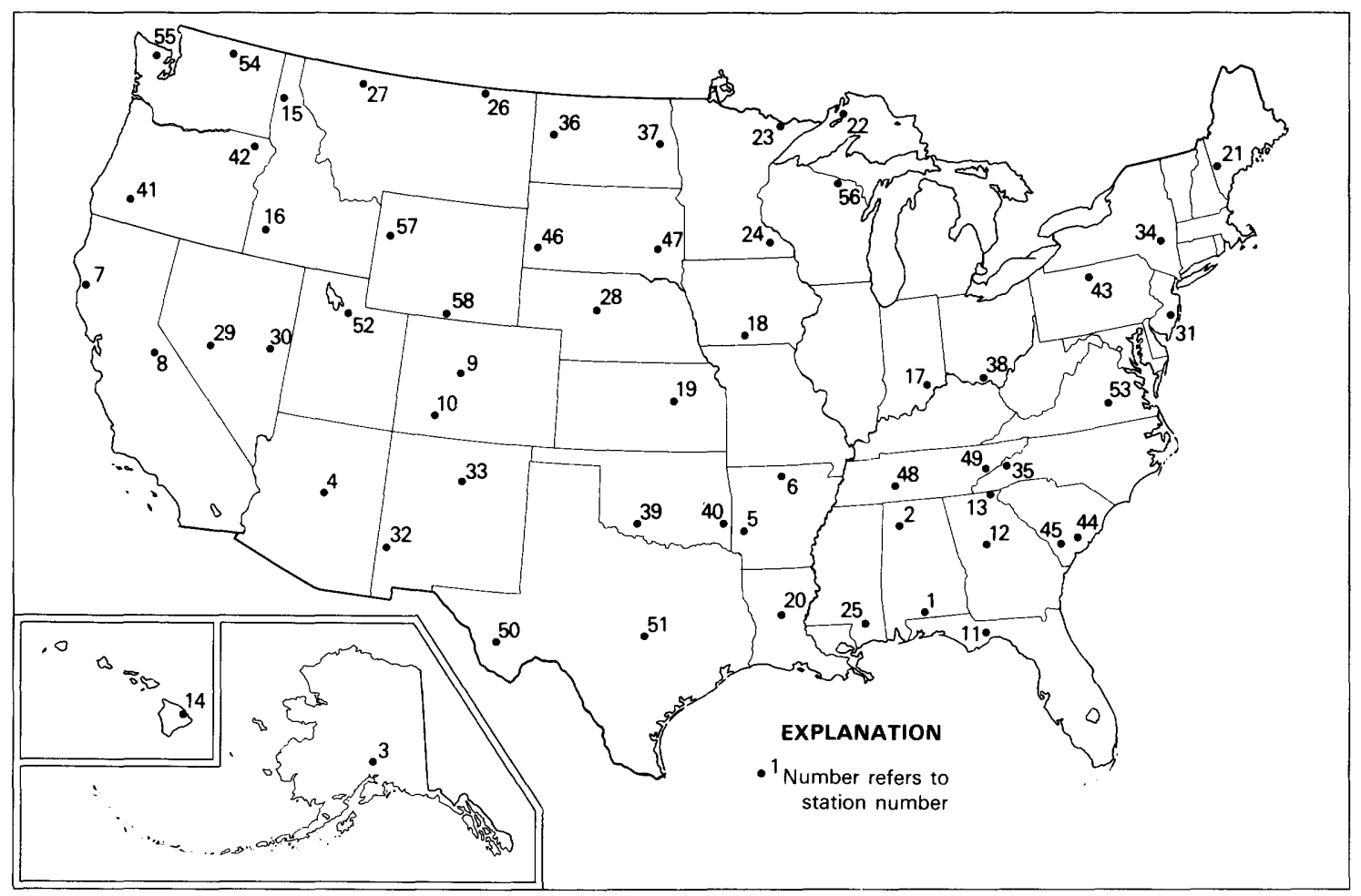

Figure 1.-Location of hydrologic bench-mark stations.

related to changes in land use, cause changes in flow characteristics. A need was recognized for a bench-marking program that would provide a stable base of records of flow collected from unchanging watersheds.

The bench-mark program was proposed in 1958 as a special-purpose monitoring network of undisturbed, undeveloped basins. Langbein and Hoyt (1959, p. 18) and Leopold (1962) suggested that the network consist of about 100 basins. The gaging stations on these basins would provide records suitable to define natural streamflow characteristics throughout the country, and would be operated permanently to document changes with time. However, because of financial considerations and because of the limited number of basins that met the stated purposes and criteria, the ultimate network will probably reach a maximum of about 60 basins. Most of the 58 streamflow and lake-level stations now in the program (fig. 1) were established in the 1960's.

The bench-mark stations were established to serve the following purposes:

1. To provide information for analyses of the hydrologic structure of natural catchments. This information can be used to study cause and effect relationships between various physiographic, meteorologic, and hydrologic variables that are free from man's influence. For example, long, continuous records of precipitation and of streamflow from relatively undisturbed basins are of great value in establishing and in evaluating the applicability of rainfall-runoff models.

2. To provide data for the development of hydrologic time series. Data collected in benchmark basins over long periods of time can be used to detect and record changes of hydrologic characteristics and to relate them to other natural factors. Temperature trends, for example, could affect streamflow by changing evapotranspiration rates.

3. To provide data as a reference or comparative base for evaluating changes in the regime of streams whose catchments or flows are later modified by man.

4. To compare information on both streamflow and water quality from the bench-mark basins with concurrent data from basins that have been modified by man. This comparison should then provide a measure of the effect of the modification on the hydrology of a basin.

In order to fulfill these purposes, the following criteria were considered in the selection of benchmark basins. 
1. No manmade storage, regulation, or diversion existed in the basin or was likely to exist for many years.

2. Ground water in the basin was not to be affected by pumping from wells.

3. Conditions were favorable for accurate measurements of streamflow, of chemical and physical quality of water, of ground-water conditions, and of the various characteristics of weather, principally precipitation.

4. There was only small probability of special natural changes due to such things as major beaver activity, overgrazing or overbrowsing by animals, or extensive fire.

Basin size was also a criterion for inclusion in the network. Large drainage basins are often partly affected by man. Very small basins respond to extremely localized climatic variations. Basins in an intermediate size range were therefore sought for inclusion in the bench-mark network.

Many of the hydrologic bench-mark stations selected in the 1960's were located in national parks, wilderness areas, state parks, national forests, or in areas reserved for scientific study. These areas were chosen because they are relatively free of man's influence. Completely natural basins of suitable size, however, no longer exist in some parts of the United States. Therefore, to obtain an adequate geographical distribution of bench marks, it was necessary to modify the proposed criterion that the selected basin be completely unaffected by man's activities. This modification resulted in the choice, for example, of Sipsey Fork basin (sta. 2) in the Bankhead National Forest of Alabama, one of several basins where selective logging is practiced. The Elk Creek basin (sta. 18) in southern Iowa, in which nearly all the land is farmed but in which little change in agricultural practices is expected, was also included in the bench-mark network. Neither the selective logging nor the agricultural use should invalidate the streamflow record as a bench-mark basin as long as the present uses are continued at the same level.

\section{THE PRESENT NETWORK}

The present (1983) bench-mark network consists of 57 streamflow stations and one lake-stage station (on Crater Lake in Oregon) in 39 States. Most of the sites were established in the 1960's and had 13 to 17 years of record through the 1980 water year. The latest additions to the network are Rock
Creek below Horse Creek near International Boundary, Mont. (sta. 26),established in October 1978; and Kings Creek near Manhattan, Kans. (sta. 19), established in April 1979. The 57 streams and 1 lake that now are included in the network are expected to remain in their present or natural condition.

One bench-mark site, Beauvais Creek near St. Xavier, MT, was removed from the bench-mark program in 1978 because channel changes isolated the gage and a suitable nearby site for gage relocation was not available.

The basins in the network encompass various natural environments. These include high mountain areas, the humid Northwest, the arid and semiarid Southwest, the Midwestern plains, the warm humid Southeast, the temperate Northeast, tropical Hawaii, and mountainous Alaska. Elevations in basins within the network range from near sea level to more than $14,000 \mathrm{ft}$ above sea level. Vegetational cover ranges from none on bare soil or rock, to lichens, to sparse desert growth, to dense growths of coniferous forests.Some basins include cropland, which is generally in small acreages.

The areas of the drainage basins range from 2.31 to $960 \mathrm{mi}^{2}$, not including the Talkeetna River basin in Alaska (sta. 3) which covers slightly more than $2,000 \mathrm{mi}^{2}$. The median basin area is $55 \mathrm{mi}^{2}$. Half of the basins drain areas of 25 to $91 \mathrm{mi}^{2}$. Streamflow data are collected continuously, and water-quality data are obtained at monthly, quarterly, or annual intervals, depending upon the particular constituent.

The network as of 1970 was described by Cobb and Biesecker (1971). Their report includes a detailed description of the natural and physical characteristics of the streams and their drainage basins and information on the types and frequency of water-quality data being collected.

Biesecker and Leifeste (1975) summarized water-quality aspects of the network through about 1972. Other scheduled reports will update the report of Biesecker and Leifeste and will include trend analysis. Detailed data, including daily discharges and quality of water information, have been published for each site in the annual waterresources data reports for the State in which the site is located.

\section{STREAMFLOW CHARACTERISTICS}

Streamflow characteristics were determined for 57 streams. A hydrograph of annual maximum and minimum stages at Crater Lake (sta. 41) is also 
included. Each site is identified by name and by the downstream order identification number as given to all stream and lake-gaging stations operated by the U.S. Geological Survey. The site location, drainage area, basin topography, rock type, vegetation, and manmade influences are included.

Other basin or streamflow characteristics needing explanation are discussed in following paragraphs.

Stations 1-58 are listed alphabetically by State, then alphabetically by station name within the State. The respective station number is the same as the index number used in figure 1 to identify the site.

Streamflow at each station in the bench-mark network is described by the application of statistical analyses to the flow data. These analyses include: Frequency and flow-duration analyses; computations of mean flow; Kendall's tau; and the serial correlation coefficient for annual mean discharge.

Period of record: The period, through the 1980 water year, for which streamflow records are available. A water year is the period from October 1 to September 30.

Average discharge: The average of annual mean flows for full water years of record through 1980.

Extremes: Maximum and minimum discharges and gage heights for the period of record.

Serial correlation coefficient: A measure of the strength of the linear relationship between annual mean discharges for consecutive years. Positive values indicate dependence between the years, such that if one year was high (or low), the next year would also tend to be high (or low). Negative values indicate an alternation of high and low years. A value of 0.0 indicates no serial correlation between years. The correlation coefficient will always fall in the range -1.0 to 1.0 .

Kendall's tau correlation coefficient: A measure of the trend of annual mean discharges over time. Values approaching 1.0 or -1.0 indicate the degree to which there is a consistent increase or decrease during the period. Kendall's tau is discussed in more detail in the section "Time Trends."

Flood frequency: The maximum annual discharges for various recurrence intervals were computed from the records of annual flood peaks by use of the log-Pearson Type III distribution (U.S. Water Resources Council, 1981). Discharges having a recurrence interval of $2,5,10$, or 25 years are shown for all streams. The discharge for a 50-year recurrence interval is shown for streams where there are more than 20 years of record and the 100-year discharge is shown for six streams where there are more than 30 years of record.

Judgment and understanding of the input data should be exercised in using flood discharge values computed from short data bases. An example is Wet Bottom Creek near Childs, AZ (sta. 4). At this station, six annual peak discharges are concentrated in a narrow range of 5,220 to $6,830 \mathrm{ft}^{3} / \mathrm{s}$. The frequency analysis based on this unusual distribution indicates that 5-year recurrence interval floods occurred in 3 out of 13 years of record but no 10-year frequency flood occurred. This distribution may indicate an unusually wet period of record, not representative of long-term streamflow conditions.

Standard deviation: The standard deviation shown is a measure of the dispersion of individual values of annual flood peaks within the sample used to compute flood-frequency distribution. Logarithmic values are used. The following examples of high and low values indicate the relative degree of variability in annual peak flows between two hydrologically dissimilar streams.

\begin{tabular}{ccc} 
Station & $\begin{array}{c}\text { Standard } \\
\text { deviation }\end{array}$ & $\begin{array}{c}\text { Ratio of 2-year flood } \\
\text { to 25-year flood }\end{array}$ \\
\hline $\begin{array}{c}\text { Little Vermillion River near, } \\
\text { Salem, SD (sta. 47)-_tord, }\end{array}$ & 1.092 & 0.025 \\
$\begin{array}{c}\text { Dismal River near Thedford } \\
\text { NE (sta. 28)- }\end{array}$ & 0.040 & 0.848 \\
\hline
\end{tabular}

Skewness coefficient: The skewness coefficient of the logarithms is a measure of the shape of the flood-frequency distribution. A positive skew indicates that the median of the array of annual flood peaks is greater than their mean, and if negative, that the median is less than their mean. The greater the absolute value of the coefficient, the greater the difference between the median and the mean. The skew is based on a weighting procedure (U.S. Water Resources Council, 1981) that uses station data and an average of values for other gaging stations in the area.

Low-flow frequency: The low-flow frequency characteristics were determined from daily discharge records for various recurrence intervals using a log-Pearson Type III distribution. For example, the annual minimum discharge for 7 consecutive days that will occur on the average of once in 10 years at Blackwater River near Bradley, $\mathrm{AL}$, (sta. 1) is $24 \mathrm{ft}^{3} / \mathrm{s}$. This is termed the "7-day 10-year" low flow. The recurrence intervals for which low flows were computed depended on the length of record at the site as in the computation of the flood frequencies. Analyses were based on 
climatic years (April 1 to March 31) of record, except for the Talkeetna River near Talkeetna, AK (sta. 3), which was based on water years because low flows there can occur near the end of March. Flow duration: The flow-duration analysis provides the percentage of time that specified mean daily discharges were exceeded. The analysis is presented as a curve.

Flow characteristics by month: The median, maximum, and minimum daily discharges for each month, and the $2,25,75$, and 99 percentile discharges from a duration analysis by months for each station are presented on graphs.

\section{FLOW CHARACTERISTICS EXPLANATION EXAMPLE \\ Percentile - Percentage of daily discharges equal to or greater than indicated value

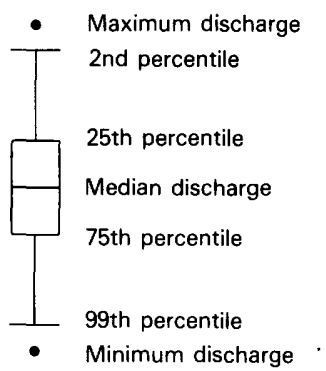

For example, at Blackwater River near Bradley, $\mathrm{AL}$, (sta. 1), daily discharge was at most $40 \mathrm{ft}^{3} / \mathrm{s}$ on 25 percent of all October days. The maximum and minimum daily discharges that occurred in October are 1,230 and $20 \mathrm{ft}^{3} / \mathrm{s}$, respectively.

Daily discharges less than $0.1 \mathrm{ft}^{3} / \mathrm{s}$ are not presented on the graphs. Discharges between 0.06 and $0.09 \mathrm{ft}^{3} / \mathrm{s}$, were rounded to $0.1 \mathrm{ft}^{3} / \mathrm{s}$; those 0.05 $\mathrm{ft}^{3} / \mathrm{s}$ and below were considered to be zero flow.

Annual mean discharge: The mean discharge for each year of record is presented on a bar graph. For six sites that had Kendall's tau correlation coefficients significant at the 5-percent level, 3 year moving averages for annual discharge and precipitation have been added. The six sites are discussed in more detail in the section titled "Time Trends."

Streamflow characteristics for Kings Creek near Manhattan, KS, (sta. 19) and Rock Creek below Horse Creek near International Boundary, MT, (sta. 26) are not included because their length of record is too short to justify this analysis.

\section{TIME TRENDS}

Possible time trends of flows at the hydrologic bench-mark stations were investigated by com- puting the statistical parameter, or correlation coefficient, Kendall's tau (Conover, 1971). Kendall's tau is a measure of the trend of the annual mean discharges over time. Values can range from -1 to +1 . A value of -1 results when each succeeding value is less than the one previous; a value of +1 results when each value is greater than the one previous. The expected value of the tau for records with no trend is zero.

A random distribution of values (here, annual alignment mean discharges) can result in an observable trend, but the chance of this occurring can be evaluated statistically. In general, the more Kendall's tau deviates from zero, the more likely it is that a trend exists. Also, the larger the sample, the less chance of a definite trend occurring by chance alone. For example, the values of tau are identical at two sites, Wild River at Gilead, ME, (sta. 21) and Castle Creek near Hill City, SD, (sta. 46). Because Castle Creek has twice the length of record of Wild River, however its tau value of 0.282 has only a 2-percent chance of occurring randomly compared to a 12-percent chance for Wild River.

There are six sites where Kendall's tau computed for annual mean discharges has a value with a less-than-5-percent chance of occurrence. Another way of stating this is that six sites have Kendall's tau values that are significant at the 5 -percent level. The stated significance level of 5-percent is based on an assumption of serial independence of the annual discharges. That is, if flows are trend free but serially dependent, the chance of attaining a "significant" value of tau will be greater than 5-percent. The six stations are:

\begin{tabular}{|c|c|}
\hline $\begin{array}{l}\text { Period of } \\
\text { record }\end{array}$ & $\begin{array}{c}\text { Kendall's } \\
\text { tau }\end{array}$ \\
\hline $\begin{array}{l}\text { Hayden Creek below North } \\
\text { Fork near Hayden Lake, } \\
\text { ID (sta. 16)- } 1949-53,1959 \text {, } \\
1966-80\end{array}$ & -0.343 \\
\hline $\begin{array}{l}\text { Washington Creek at } \\
\text { Windigo, Isle Royale, MI } \\
\text { (sta. 22) }\end{array}$ & -0.533 \\
\hline $\begin{array}{l}\text { Cypress Creek near Janice, } \\
\text { MS (sta.25) }\end{array}$ & 0.648 \\
\hline $\begin{array}{l}\text { Esopus Creek at Shandaken, } \\
\text { NY (sta. 34) }\end{array}$ & 0.559 \\
\hline $\begin{array}{l}\text { Young Womans Creek near } \\
\text { Renovo, PA } \\
\text { (sta. 43)--1966-80 }\end{array}$ & 0.486 \\
\hline $\begin{array}{l}\text { Castle Creek near Hill City, } \\
\text { SD (sta. 46) }\end{array}$ & 0.282 \\
\hline
\end{tabular}

Flows at two of the six stations show a decreasing trend of annual mean discharges, and 
four show an increasing trend. To determine if this trend was the result of a trend in precipitation, the annual mean discharge for each station was compared to annual precipitation recorded at a nearby weather station.

Plots of the 3-year moving averages of precipitation and annual mean discharge were made to smooth out the variability of individual years. These plots are shown in the streamflowdata section of this report for these six stations.

All six plots showed a strong relationship between change in discharge and change in precipitation. One pronounced exception occurred for the period 1969-71 at Washington Creek at Windigo, Isle Royale, MI, (sta. 22), where a period of high precipitation did not show a corresponding period of high discharge. The nearest long-term precipitation station however is $60 \mathrm{mi}$ from this isolated basin on an island in Lake Superior, and is across part of the lake. Therefore, the streamflow and precipitation stations may measure different climatic effects.

This brief analysis indicates that trends in stream runoff at six of the basins in the hydrologic bench-mark network are related to variations in precipitation. The influences of man's activities, if any, were not evaluated. The few (6 of 57) instances of identified trends indicates the general value of the hydrologic bench-mark network as a stable base of hydrologic information.

\section{REFERENCES}

Biesecker, J. E., and Leifeste, D. K., 1975, Water quality of hydrologic bench marks-an indicator of water quality in the natural environment: U.S. Geological Survey Circular 460-E, $21 \mathrm{p}$.

Cobb, E. D., and Biesecker, J. E., 1971, The national hydrologic bench-mark network: U.S. Geological Survey Circular 460-D, $38 \mathrm{p}$.

Conover, W. J., 1971, Practical nonparametric statistics: New York, John Wiley \& Sons, Inc., 462 p.

Langbein, W. B., and Hoyt, W. G., 1959, Water facts for the nation's future: New York, Ronald Press Co., 288 p.

Leopold, L. B., 1962, A national network of hydrologic bench marks: U.S. Geological Survey Circular 460-B, 4 p.

U.S. Water Resources Council, 1981, Guidelines for determining flood flow frequency: Water Resources Council Bulletin No. $17 \mathrm{~B}, 183 \mathrm{p}$. 


\section{FIFTY-EIGHT HYDROLOGIC BENCH-MARK STATIONS}


Station 1. - Blackwater River near Bradley, AL (02369800)

Location: Lat $31^{\circ} 01^{\prime} 39^{\prime \prime}$, long $86^{\circ} 42^{\prime} 36^{\prime \prime}$, Escambia County, 1.0 mi east of Bradley.

Drainage area: $86.8 \mathrm{mi}^{2}$.

Topography: The uplands are gently rolling ridges which are somewhat broken in the central part of the basin. A few sinks and depressions are scattered in the eastern basin area. Elevations range from the 125 to $300 \mathrm{ft}$.

Rock type: Clay, sandy clay, sand, gravel, and sandstone.

Vegetation: About 90 percent of the basin is covered by pine and hardwood forest. The remainder is in pasture and row crops. The upland forest is predominantly longleaf pine and there is a dense wiregrass ground cover. The lowland forest is about 90 percent pine and 10 percent bay hardwood; the undergrowth is dense.

Manmade influences: About 60 percent of the basin is publicly owned. Sections of this land are periodically logged. Extensive erosion control is practiced. Of the privately owned land about 70 percent is forested and 30 percent is pasture or is cultivated. Not more than 10 percent of the privately owned forest is normally cut in any one year. The land in row crops may produce disproportionately high sediment yields. Three small communities are within the basin.

Period of record: December 1967 to September 1980.

Average discharge: $159 \mathrm{ft}^{3} / \mathrm{s}$.

Extremes: Maximum discharge, not determined, occurred June 4, 1970, gage height, $24.20 \mathrm{ft}$; maximum daily, 11,100 $\mathrm{ft}^{3} / \mathrm{s}$, June 4, 1970; minimum, $18 \mathrm{ft}^{3} / \mathrm{s}$, September 15, 16, 1968.

Serial correlation coefficient for annual mean discharges: -0.009 .

Kendall's tau correlation coefficient for annual mean discharges: 0.359 .

\section{FLOW DURATION}

\begin{tabular}{|c|rrrr|}
\hline \multicolumn{5}{|c|}{ FLOOD FREQUENCY } \\
\hline \multicolumn{4}{|c|}{$\begin{array}{l}\text { Peak discharge, in cubic feet per second, for } \\
\text { indicated recurrence interval, in years }\end{array}$} \\
\hline $\begin{array}{c}\text { R. I. } \\
\text { Discharge }\end{array}$ & 2 & 5 & 10 & 25 \\
\hline
\end{tabular}

Standard Deviation (logs): 0.453

Skewness Coefficient (logs): 0.202

\begin{tabular}{|c|cccc|}
\hline \multicolumn{4}{|c|}{ LOW-FLOW FREQUENCY } \\
\hline $\begin{array}{l}\text { Consecutive } \\
\text { day period }\end{array}$ & \multicolumn{3}{|c|}{$\begin{array}{l}\text { Discharge, in cubic feet per second for } \\
\text { indicated recurrence interval, in years }\end{array}$} \\
\hline & 2 & 5 & 10 & 20 \\
\cline { 2 - 5 } 7 & 39 & 28 & 24 & 21 \\
14 & 41 & 29 & 25 & 22 \\
30 & 44 & 32 & 27 & 24 \\
60 & 51 & 36 & 31 & 28 \\
90 & 60 & 43 & 37 & 33 \\
\hline
\end{tabular}

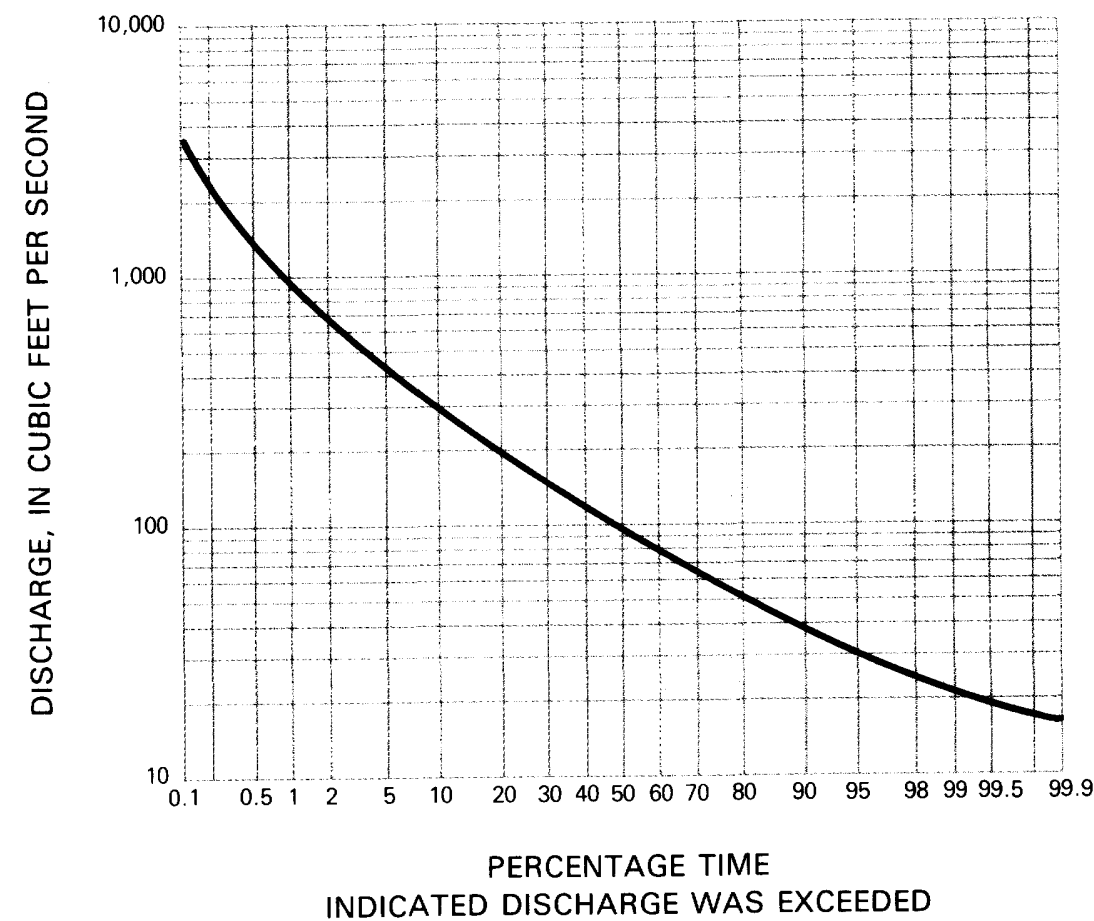



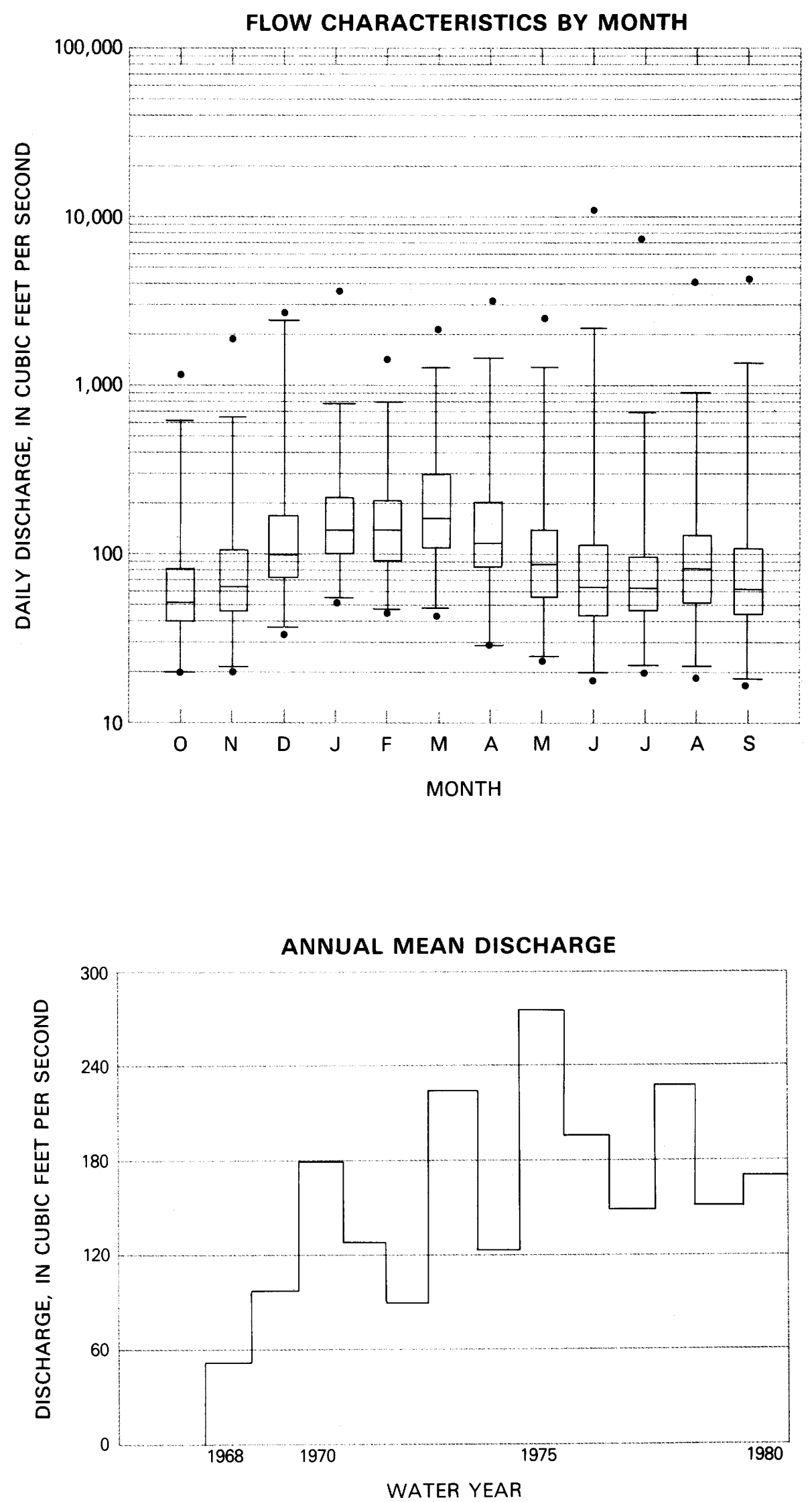
Station 2.-Sipsey Fork near Grayson, AL (02450250)

Location: Lat $34^{\circ} 17^{\prime} 07^{\prime \prime}$, long $87^{\circ} 23^{\prime} 56^{\prime \prime}$, Winston County, 4.5 mi west of Grayson.

Drainage area: $90.1 \mathrm{mi}^{2}$.

Topography: Gently rolling plateaus having deeply entrenched valleys. Elevations range from 550 to 1,050 ft. The slope of the main stream is $11 \mathrm{ft} / \mathrm{mi}$.

Rock type: Sandstone, shale, limestone, and chert.

Vegetation: About 98 percent of the basin is covered with mixed pine and hardwood forest. A few ridgetops and upper slopes have been converted to all pine forest as a result of timbering practices.

Manmade influences: Several domestic wells pump water along the northern drainage divide. The basin is in the Bankhead National Forest and logging is practiced in such a way that no more than 10 percent of the basin will be logged in any one year. Logging is performed only on the upper parts of the basin and erosion control is practiced. The logged areas are replanted and logging trails are seeded with grass. Several roads traverse the basin.

Period of record: October 1966 to September 1980.

Average discharge: $176 \mathrm{ft}^{3} / \mathrm{s}$.

Extremes: Maximum discharge, 20,300 ft $3 / \mathrm{s}$, March 16, 1973, gage height, $44.27 \mathrm{ft}$; minimum, $1.8 \mathrm{ft} / 3$, August 19-21, 1972.

Serial correlation coefficient for annual mean discharges: 0.027 .

Kendall's tau correlation coefficient for annual mean discharges: 0.253.

FLOW DURATION

\begin{tabular}{|c|rrrr|}
\hline \multicolumn{5}{|c|}{ FLOOD FREQUENCY } \\
\hline \multicolumn{4}{|c|}{ Peak discharge, in cubic feet per second, for } \\
indicated recurrence interval, in years \\
\hline $\begin{array}{c}\text { R. I. } \\
\text { Discharge }\end{array}$ & 2 & 5 & 10 & 25 \\
\hline
\end{tabular}

Standard Deviation (logs): 0.229

Skewness Coefficient (logs): -0.140

\begin{tabular}{|c|cccc|}
\hline \multicolumn{4}{|c|}{ LOW-FLOW FREQUENCY } \\
\hline $\begin{array}{c}\text { Consecutive } \\
\text { day period }\end{array}$ & \multicolumn{4}{|c|}{$\begin{array}{c}\text { Discharge, in cubic feet per second for } \\
\text { indicated recurrence interval, in years }\end{array}$} \\
\hline & 2 & 5 & 10 & 20 \\
\cline { 2 - 5 } 7 & 4.3 & 2.8 & 2.3 & 2.0 \\
14 & 4.9 & 3.1 & 2.6 & 2.2 \\
30 & 6.4 & 3.9 & 3.1 & 2.6 \\
60 & 9.1 & 5.0 & 3.9 & 3.2 \\
90 & 12.7 & 6.4 & 4.6 & 3.5 \\
\hline
\end{tabular}

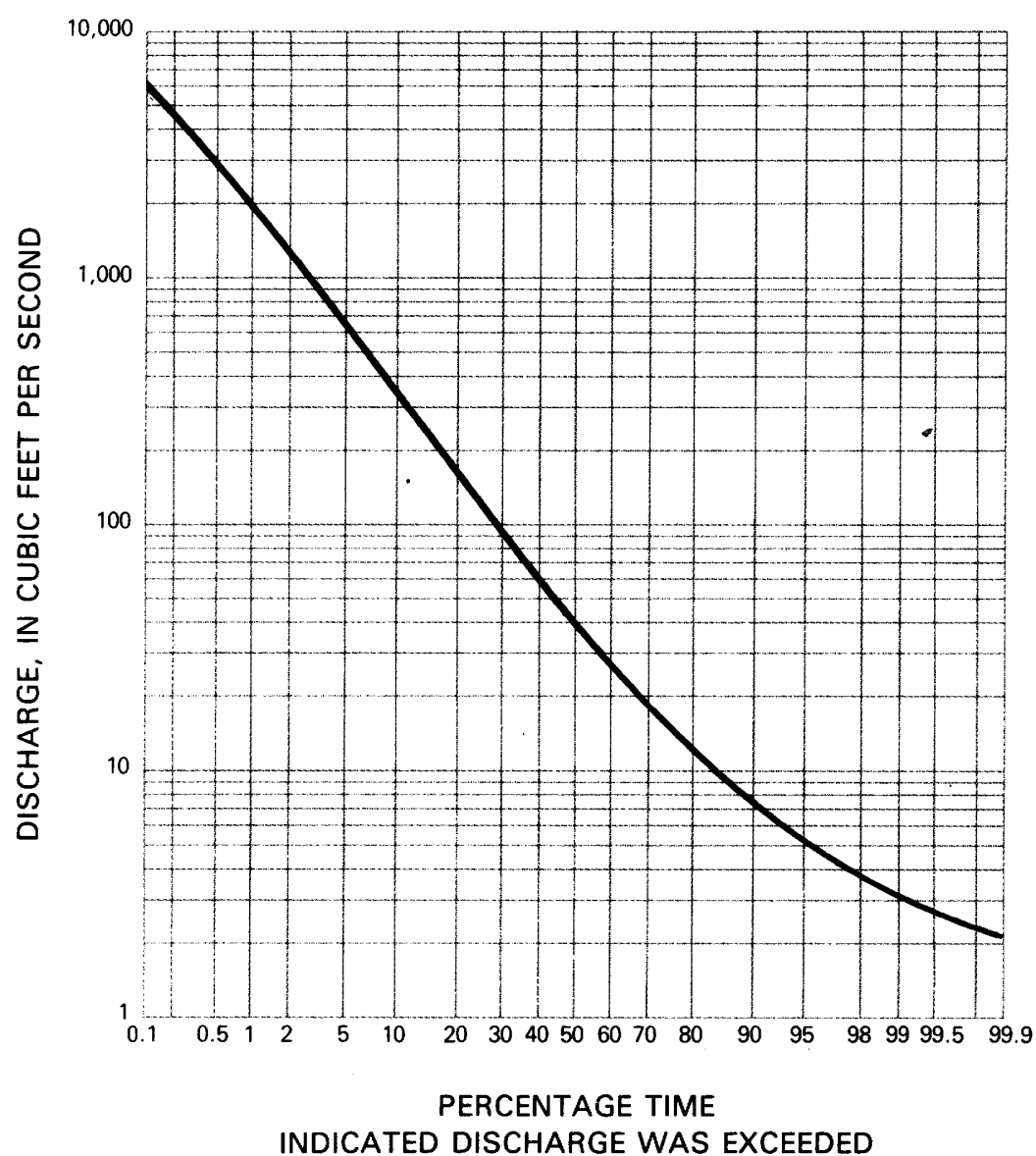



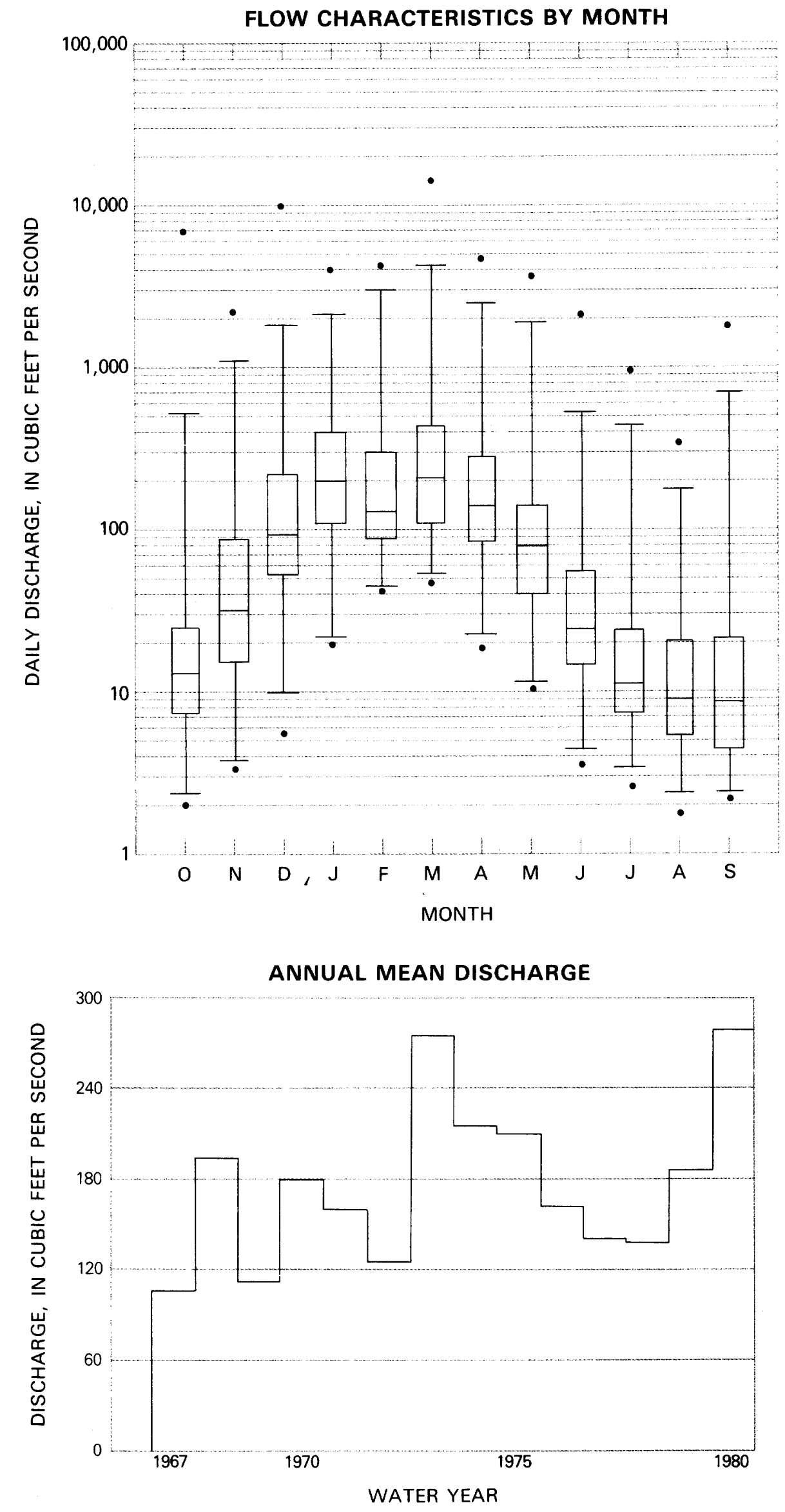
Station 3. - Talkeetna River near Talkeetna, AK (15292700)

Location: Lat $62^{\circ} 20^{\prime} 49^{\prime \prime}$, long $150^{\circ} 01^{\prime} 01^{\prime \prime}$, Matanuska-Susitna Borough, $3.5 \mathrm{mi}$ northeast of Talkeetna.

Drainage area: $2,006 \mathrm{mi}^{2}$.

Topography: Mountainous; maximum relief about $7,000 \mathrm{ft}$; mountains in the northwest part of the basin have been greatly rounded by large Pleistocene valley glaciers that covered the area to an altitude of more than $3,000 \mathrm{ft}$.

Rock type: Thin (less than $20 \mathrm{ft}$ thick) glacial drift and colluvium underlain primarily by intrusive and extrusive igneous rocks. Glacial outwash occurs as valley train deposits along the flood plain of the Talkeetna River.

Vegetation: About 25 percent of the basin is covered by a mixed conifer (spruce) and deciduous (birch, poplar, alder) forest. At higher altitudes, the forest becomes mixed shrubs, and then becomes tundra. About 7 percent of the area is glacier covered and some is bare rock.

Manmade influences: There are no towns in the basin and the only buildings are scattered cabins inhabited by recreational users, trappers, and miners. However, these inhabitations are increasing.

Period of record: June 1964 to September 1980.

Average discharge: $4,050 \mathrm{ft}^{3} / \mathrm{s}$.

Extremes: Maximum discharge, $67,400 \mathrm{ft}^{3} / \mathrm{s}$, August 10, 1971, gage height, $16.35 \mathrm{ft}$; minimum daily, about $380 \mathrm{ft}^{3} / \mathrm{s}$, February 21 to April 10, 1969.

Serial correlation coefficient for annual mean discharges: -0.062 .

Kendall's tau correlation coefficient for annual mean discharges: -0.167 .

\begin{tabular}{|c|rrrr|}
\hline \multicolumn{5}{|c|}{ FLOOD FREQUENCY } \\
\hline \multicolumn{4}{|c|}{$\begin{array}{l}\text { Peak discharge, in cubic feet per second, for } \\
\text { indicated recurrence interval, in years }\end{array}$} \\
\hline $\begin{array}{c}\text { R. I. } \\
\text { Discharge }\end{array}$ & 2 & 5 & 10 & 25 \\
\hline
\end{tabular}

Standard Deviation (logs): 0.161 Skewness Coefficient (logs): 0.778

\begin{tabular}{|c|cccc|}
\hline \multicolumn{4}{|c|}{ LOW-FLOW FREQUENCY } \\
\hline $\begin{array}{l}\text { Consecutive } \\
\text { day period }\end{array}$ & \multicolumn{3}{|c|}{$\begin{array}{l}\text { Discharge, in cubic feet per second for } \\
\text { indicated recurrence interval, in years }\end{array}$} \\
\hline & 2 & 5 & 10 & 20 \\
\cline { 2 - 5 } 7 & 464 & 407 & 387 & 374 \\
14 & 466 & 409 & 389 & 375 \\
30 & 472 & 414 & 393 & 379 \\
60 & 494 & 431 & 407 & 390 \\
90 & 523 & 457 & 431 & 412 \\
\hline
\end{tabular}

\section{FLOW DURATION}

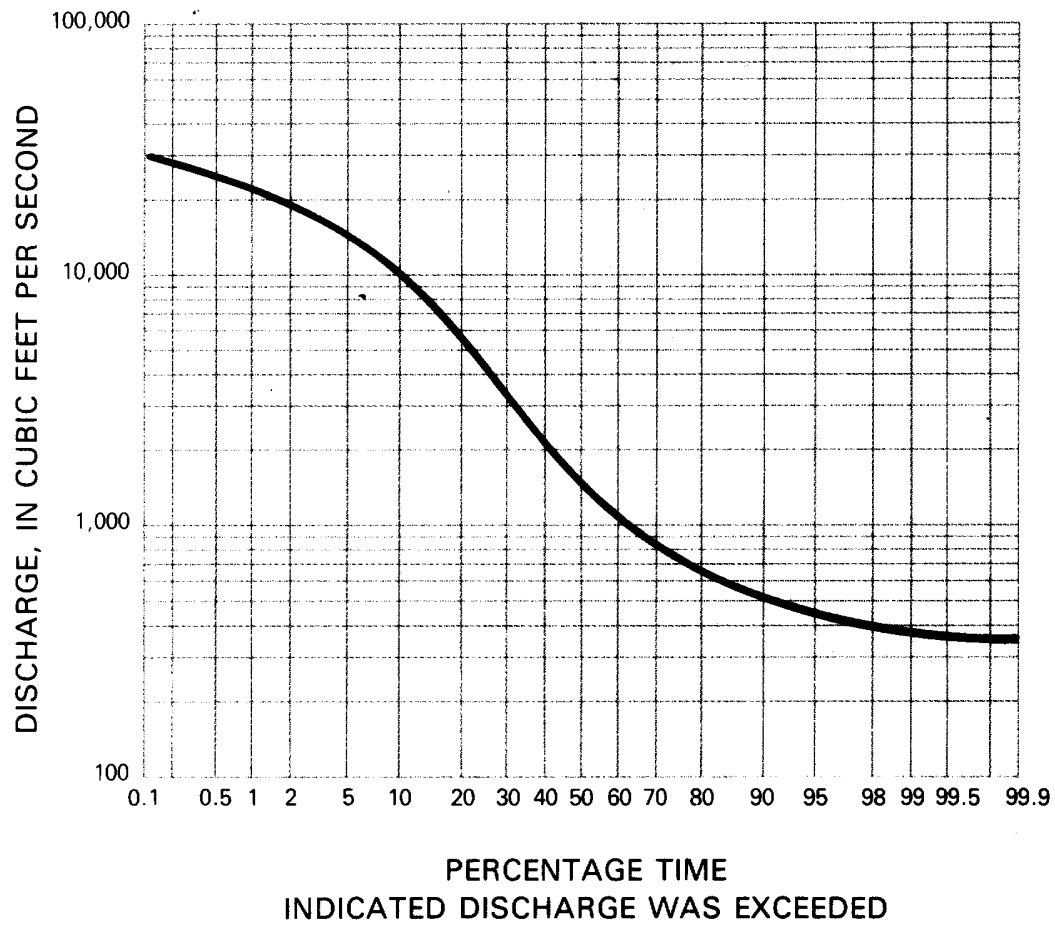



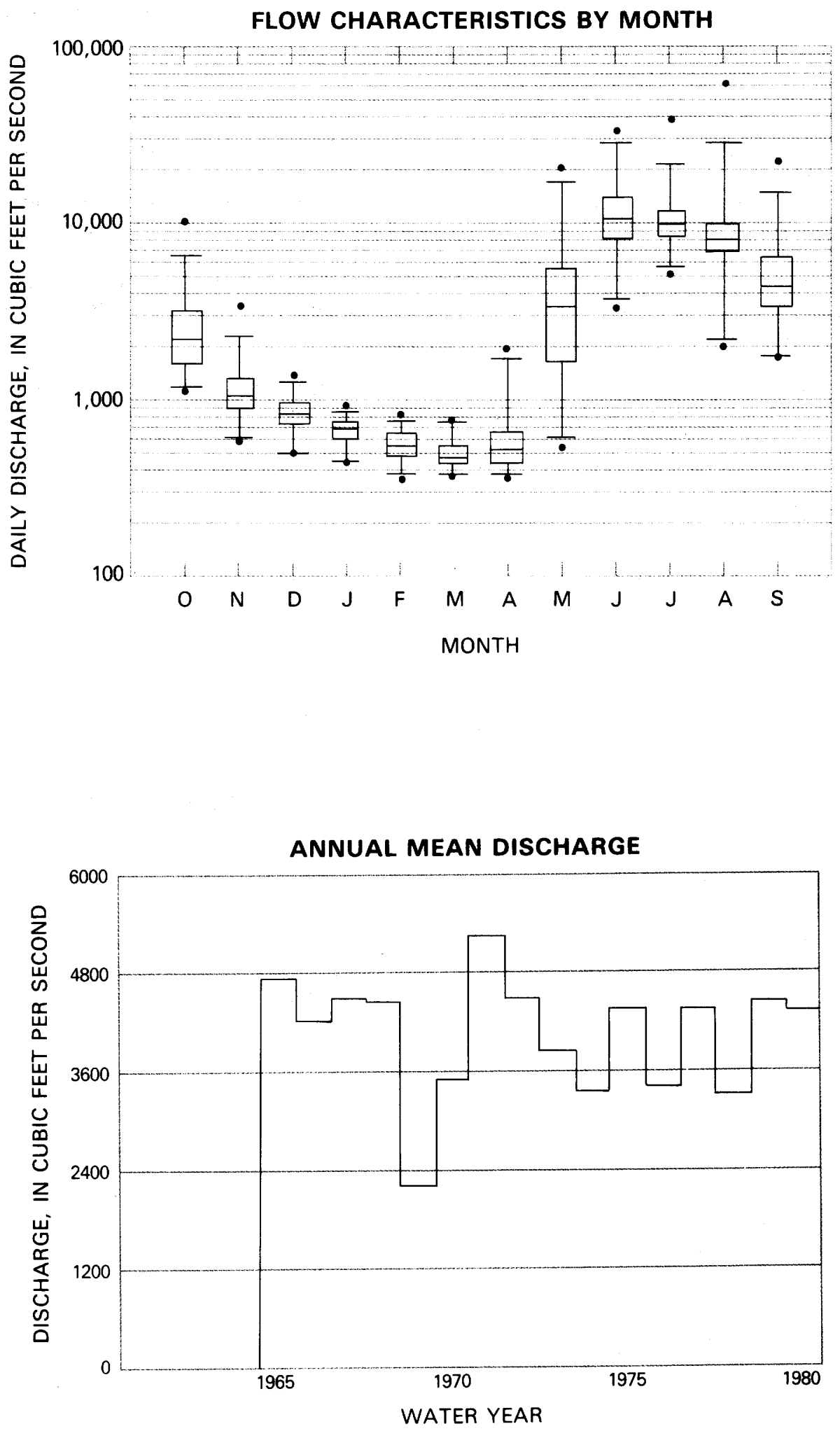
Station 4.-Wet Bottom Creek near Childs, AZ (09508300)

Location: Lat $34^{\circ} 09^{\prime} 39^{\prime \prime}$, long $111^{\circ} 41^{\prime} 32^{\prime \prime}$, Gila County, 13 mi south of Childs.

Drainage area: $36.4 \mathrm{mi}^{2}$.

Topography: Rugged with many mesas and ridges separated by steep canyons. Elevations range from 2,200 to 7,450

$\mathrm{ft}$. The slope of the main stream is about $200 \mathrm{ft} / \mathrm{mi}$.

Rock type: Mostly granite with large outcrops of basaltic andesite.

Vegetation: Chaparral except for pinon-juniper and pine at high elevations.

Manmade influences: Most of the basin is in the Mazatzal Wilderness Area and is completely within the Tonto National Forest. The basin is protected from manmade changes except for the minor effects of livestock grazing.

Period of record: June 1967 to September 1980.

Average discharge: $15.8 \mathrm{ft}^{3} / \mathrm{s}$.

Extremes: Maximum discharge, 6,830 ft $3 / \mathrm{s}$, February 19, 1980, gage height, $16.0 \mathrm{ft}$, in gage well, from rating curve extended above $3,000 \mathrm{ft}^{3} / \mathrm{s}$ on basis of slope-area measurements at gage heights $9.77,14.18$, and $15.66 \mathrm{ft}$; no flow at times.

Serial correlation coefficient for annual mean discharges: 0.187 .

Kendall's tau correlation coefficient for annual mean discharges: 0.333 .

\begin{tabular}{|c|rrrr|}
\hline \multicolumn{5}{|c|}{ FLOOD FREQUENCY } \\
\hline \multicolumn{4}{|c|}{$\begin{array}{c}\text { Peak discharge, in cubic feet per second, for } \\
\text { indicated recurrence interval, in years }\end{array}$} \\
\hline R. I. & 2 & 5 & 10 & 25 \\
Discharge & 1,480 & 6,190 & 12,300 & 24,600 \\
\hline
\end{tabular}

Standard Deviation (logs): 0.784

Skewness Coefficient (logs): -0.366

\begin{tabular}{|c|cc|}
\hline \multicolumn{2}{|c|}{ LOW-FLOW FREQUENCY } \\
\hline $\begin{array}{c}\text { Consecutive } \\
\text { day period }\end{array}$ & $\begin{array}{c}\text { Discharge, in cubic feet per second for } \\
\text { indicated recurrence interval, in years }\end{array}$ \\
\hline & 2 & 5 \\
\cline { 2 - 3 } 7 & 50 \\
14 & Long periods of no \\
30 & flow most years. \\
90 & \\
\hline
\end{tabular}

FLOW DURATION

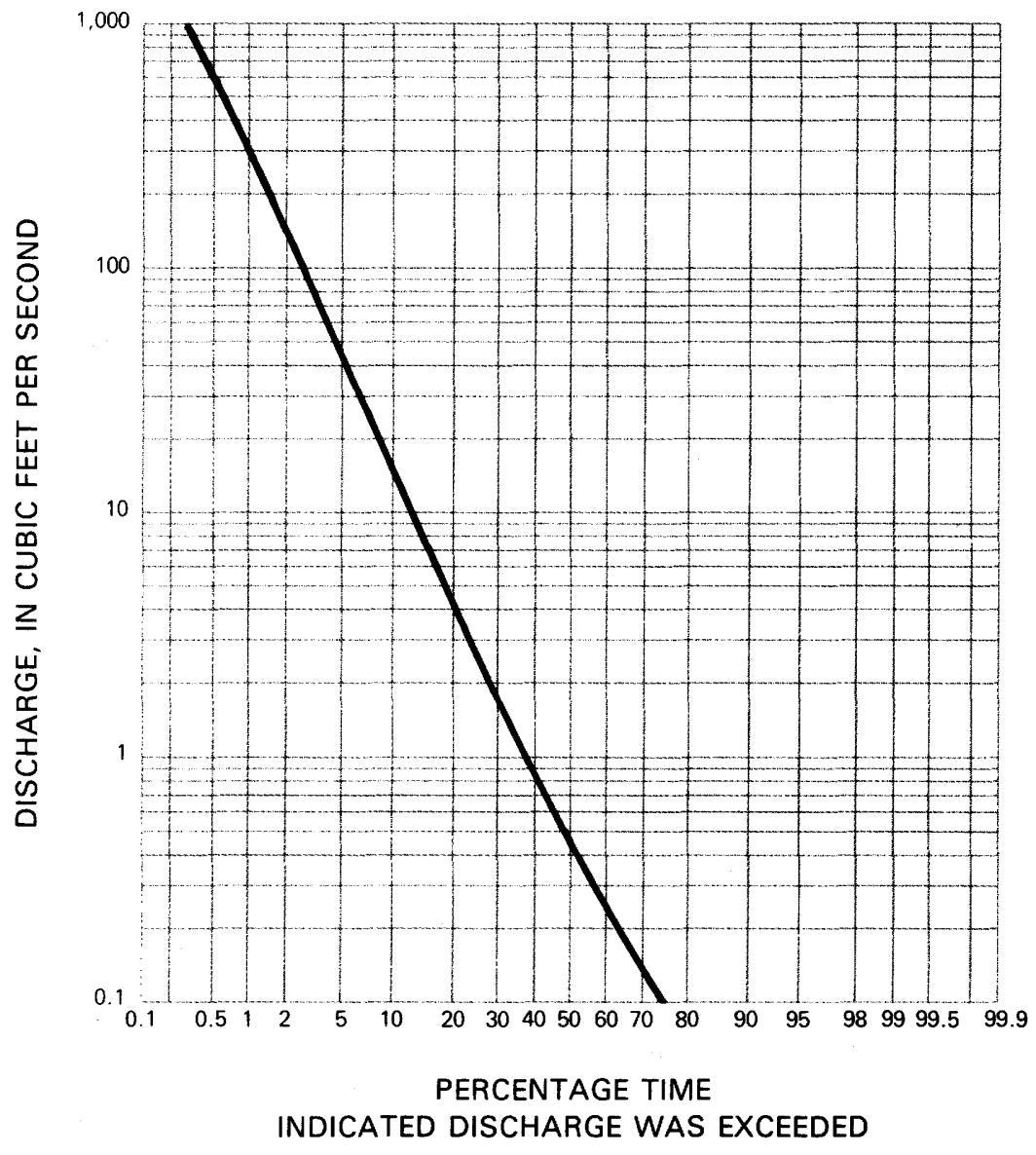



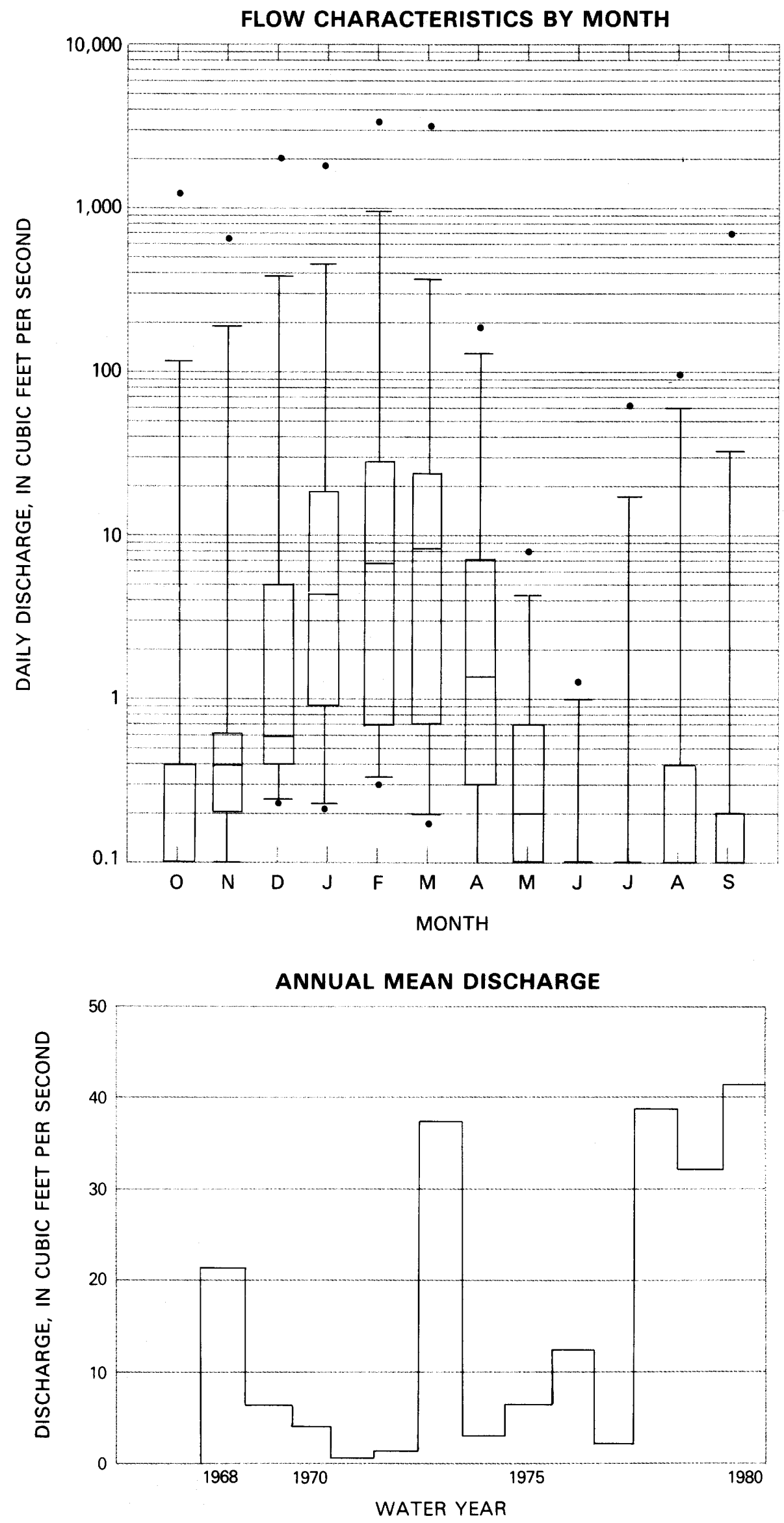
Station 5. - Cossatot River near Vandervoort, AR (07340300)

Location: Lat $34^{\circ} 22^{\prime} 46^{\prime \prime}$, long $94^{\circ} 14^{\prime} 08^{\prime \prime}$, Polk County, 7.5 mi east of Vandervoort.

Drainage area: $89.6 \mathrm{mi}^{2}$.

Topography: Hilly and having narrow valleys in the lower basin and east-west trending ridges in the upper basin. Elevations range from 780 to $2,240 \mathrm{ft}$. The slope of the main stream is about $22 \mathrm{ft} / \mathrm{mi}$.

Rock type: Shale and highly compacted sandstone in the lower basin and novaculite and slate ridges in the upper basin.

Vegetation: Mixed coniferous and deciduous forest. Moderately thick undergrowth.

Manmade influences: About 95 percent of the basin is in the Ouachita National Forest. Selective timber harvesting is controlled by the U.S. Forest Service. A few small recreational areas have been developed in the basin.

Period of record: June 1967 to September 1980.

Average discharge: $197 \mathrm{ft}^{3} / \mathrm{s}$.

Extremes: Maximum discharge, 31,500 ft $3 / \mathrm{s}$, December 9, 1971, gage height, $19.35 \mathrm{ft}$ from rating curve extended above $11,000 \mathrm{ft}^{3} / \mathrm{s}$ on the basis of step-backwater computations; minimum, $7.2 \mathrm{ft}^{3} / \mathrm{s}$, August 28, 29, 30, 31, 1972; gage height, $1.67 \mathrm{ft}$.

Serial correlation coefficient for annual mean discharges: 0.064 .

Kendall's tau correlation coefficient for annual mean discharges: -0.308 .

\begin{tabular}{|c|rrrr|}
\hline \multicolumn{4}{|c|}{ FLOOD FREQUENCY } \\
\hline \multicolumn{4}{|c|}{$\begin{array}{l}\text { Peak discharge, in cubic feet per second, for } \\
\text { indicated recurrence interval, in years }\end{array}$} \\
\hline $\begin{array}{c}\text { R. I. } \\
\text { Discharge }\end{array}$ & 2 & 5 & 10 & 25 \\
\hline
\end{tabular}

Standard Deviation (logs): 0.343

Skewness Coefficient (logs): -0.616

\begin{tabular}{|c|cccc|}
\hline \multicolumn{4}{|c|}{ LOW-FLOW FREQUENCY } \\
\hline $\begin{array}{c}\text { Consecutive } \\
\text { day period }\end{array}$ & \multicolumn{3}{|c|}{$\begin{array}{l}\text { Discharge, in cubic feet per second for } \\
\text { indicated recurrence interval, in years }\end{array}$} \\
\hline & 2 & 5 & 10 & 20 \\
\cline { 2 - 5 } & 11.9 & 9.6 & 8.4 & 7.6 \\
14 & 12.9 & 10.4 & 9.2 & 8.3 \\
30 & 14.5 & 11.3 & 10.1 & 9.2 \\
60 & 18.6 & 13.5 & 11.6 & 10 \\
90 & 23.6 & 15.1 & 12.5 & 11 \\
\hline
\end{tabular}

\section{FLOW DURATION}

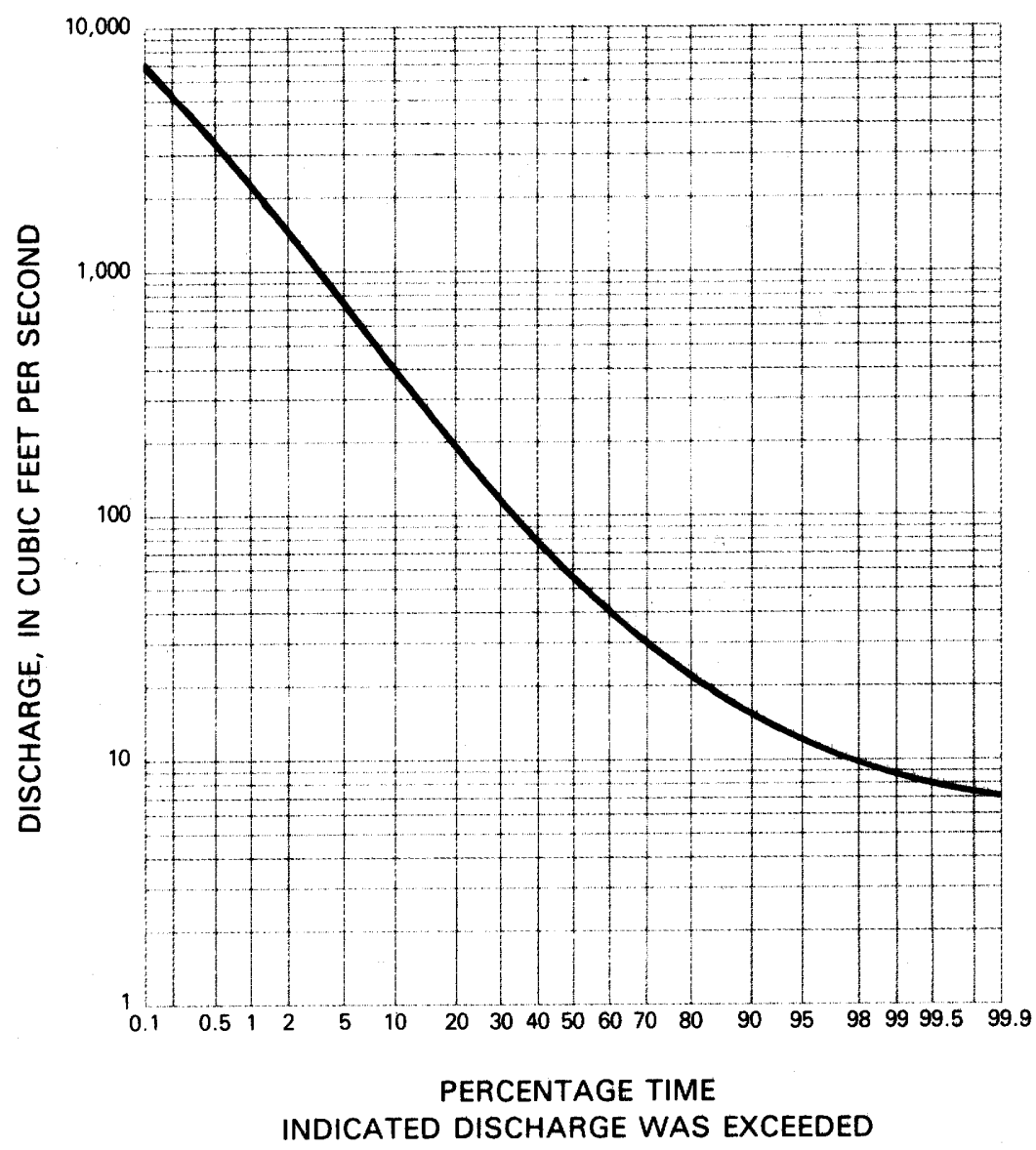



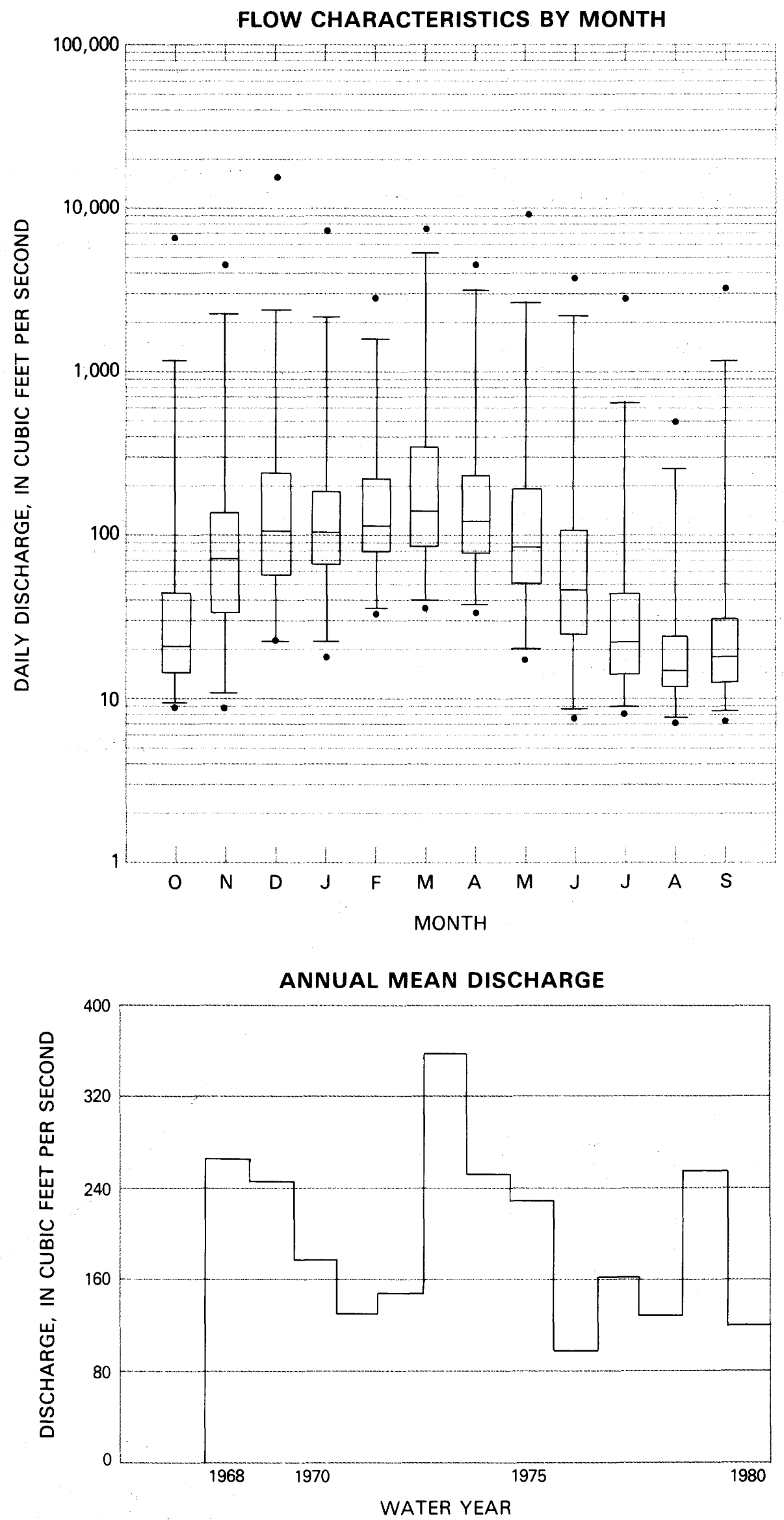
Station 6. - North Sylamore Creek near Fifty Six, AR (07060710)

Location: Lat: $35^{\circ} 59^{\prime} 30^{\prime \prime}$, long $92^{\circ} 12^{\prime} 50^{\prime \prime}$, Stone County, 2.7 mi north of Fifty Six.

Drainage area: $58.1 \mathrm{mi}^{2}$.

Topography: Rugged rolling hills. Basin elevations range from 450 to 1,400 ft; a mean basin divide elevation is about $1,200 \mathrm{ft}$. The main stream slope is about $35 \mathrm{ft} / \mathrm{mi}$.

Rock type: Mostly limestone and some sandstone.

Vegetation: Mixed coniferous and deciduous forest. Moderately thick undergrowth.

Manmade influences: Most of the basin is in the Ozark National Forest. Selective timber harvesting is controlled by the U.S. Forest Service. Some small recreational areas have been developed in the basin.

Period of record: December 1965 to September 1980.

Average discharge: $49.3 \mathrm{ft}^{3} / \mathrm{s}$.

Extremes: Maximum discharge, 17,800 ft $3 / \mathrm{s}$, April 22, 1973, gage height, $17.61 \mathrm{ft}$, from floodmarks, from rating curve extended above $3,700 \mathrm{ft}^{3} / \mathrm{s}$ on basis of step-backwater computations; minimum, $1.6 \mathrm{ft}^{3} / \mathrm{s}$, November 22, 1978.

Serial correlation coefficient for annual mean discharges: 0.077 .

Kendall's tau correlation coefficient for annual mean discharges: -0.077 .

\begin{tabular}{|c|rrrr|}
\hline \multicolumn{5}{|c|}{ FLOOD FREQUENCY } \\
\hline \multicolumn{4}{|c|}{$\begin{array}{c}\text { Peak discharge, in cubic feet per second, for } \\
\text { indicated recurrence interval, in years }\end{array}$} \\
\hline $\begin{array}{c}\text { R. I. } \\
\text { Discharge }\end{array}$ & 2 & 5 & 10 & 25 \\
\hline
\end{tabular}

Standard Deviation (logs): 0.488

Skewness Coefficient (logs): -0.543

\begin{tabular}{|c|cccc|}
\hline \multicolumn{5}{|c|}{ LOW-FLOW FREQUENCY } \\
\hline $\begin{array}{c}\text { Consecutive } \\
\text { day period }\end{array}$ & \multicolumn{3}{|c|}{$\begin{array}{l}\text { Discharge, in cubic feet per second for } \\
\text { indicated recurrence interval, in years }\end{array}$} \\
\hline & 2 & 5 & 10 & 20 \\
\cline { 2 - 5 } 7 & 3.3 & 2.6 & 2.3 & 2.1 \\
14 & 3.5 & 2.9 & 2.6 & 2.3 \\
30 & 4.2 & 3.2 & 2.8 & 2.6 \\
60 & 5.1 & 4.0 & 3.5 & 3.1 \\
90 & 5.7 & 4.4 & 4.0 & 3.8 \\
\hline
\end{tabular}

\section{FLOW DURATION}

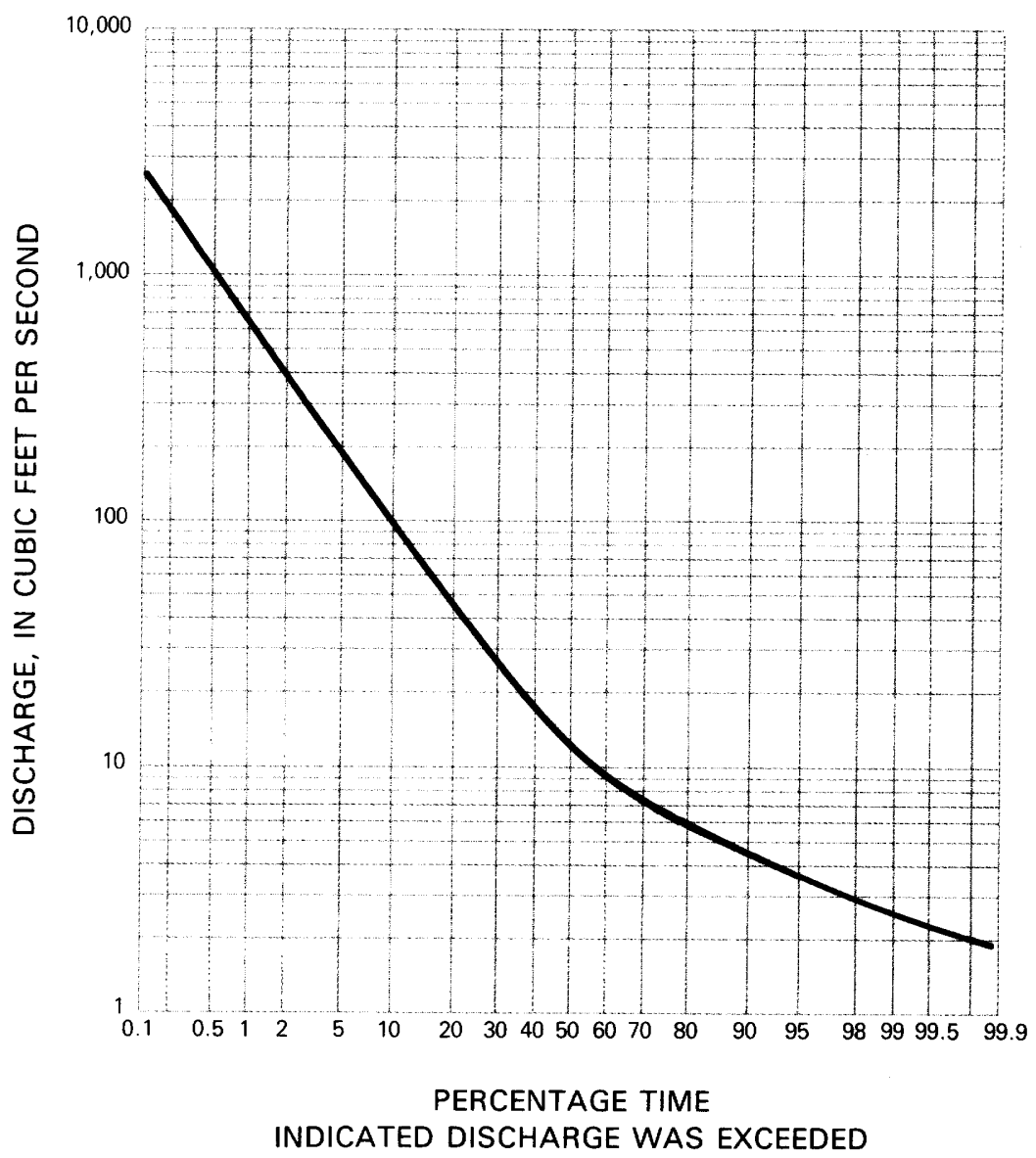



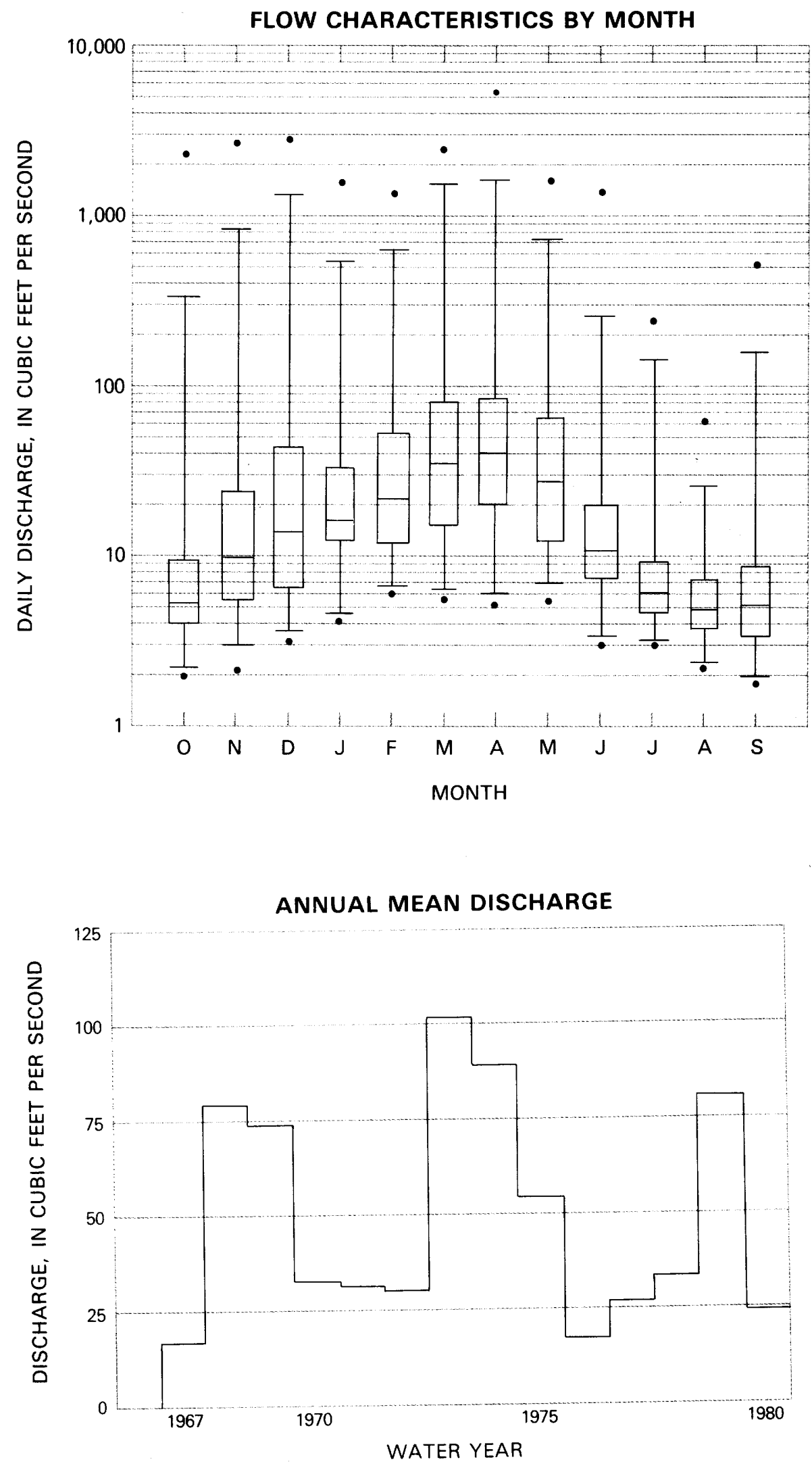
Station 7.-Elder Creek near Branscomb, CA (11475560)

Location: Lat $39^{\circ} 43^{\prime} 47^{\prime \prime}$, long $123^{\circ} 38^{\prime} 34^{\prime \prime}$, Mendocino County, 5.3 mi north of Branscomb.

Drainage area: $6.5 \mathrm{mi}^{2}$.

Topography: Narrow valleys and steep land slopes. Basin elevations range from 1,450 to 4,200 ft.

Rock type: The underlying rocks are of sedimentary marine origin. Valleys contain thin layers of alluvium of Holocene age.

Vegetation: The basin is covered with a virgin forest mostly of Douglas fir but with some pines. The cover is dense.

Manmade influences: The basin is under the control of Nature Conservancy and is protected from unnatural influences. Two radio facilities and a lookout tower atop peaks on the basin perimeter are not significant.

Period of record: October 1967 to September 1980.

Average discharge: $26.6 \mathrm{ft}^{3} / \mathrm{s}$.

Extremes: Maximum discharge, 2,280 ft $3 / \mathrm{s}$, March 29,1974, gage height, $9.77 \mathrm{ft}$, from rating curve extended above $660 \mathrm{ft}^{3} / \mathrm{s}$ on basis of slope-area measurements at gage heights $9.40 \mathrm{ft}$ and $11.41 \mathrm{ft}$; minimum daily, $0.39 \mathrm{ft}^{3} / \mathrm{s}$, August 13-23, September 7-15, 1977.

Serial correlation coefficient for annual mean discharges: 0.034 .

Kendall's tau correlation coefficient for annual mean discharges: -0.205 .

\begin{tabular}{|c|rrrr|}
\hline \multicolumn{5}{|c|}{ FLOOD FREQUENCY } \\
\hline \multicolumn{4}{|c|}{ Peak discharge, in cubic feet per second, for } \\
indicated recurrence interval, in years \\
\hline R. I. & 2 & 5 & 10 & 25 \\
Discharge & 644 & 1,130 & 1,520 & 2,060 \\
\hline
\end{tabular}

Standard Deviation (logs): 0.296

Skewness Coefficient (logs): -0.089

\begin{tabular}{|c|cccc|}
\hline \multicolumn{5}{|c|}{ LOW-FLOW FREQUENCY } \\
\hline $\begin{array}{c}\text { Consecutive } \\
\text { day period }\end{array}$ & \multicolumn{3}{|c|}{$\begin{array}{l}\text { Discharge, in cubic feet per second for } \\
\text { indicated recurrence interval, in years }\end{array}$} \\
\hline & 2 & 5 & 10 & 20 \\
\cline { 2 - 5 } 7 & 0.8 & 0.6 & 0.5 & 0.4 \\
14 & 0.8 & 0.6 & 0.5 & 0.4 \\
30 & 0.9 & 0.7 & 0.6 & 0.5 \\
60 & 1.0 & 0.7 & 0.6 & 0.5 \\
90 & 1.2 & 0.9 & 0.8 & 0.7 \\
\hline
\end{tabular}

\section{FLOW DURATION}

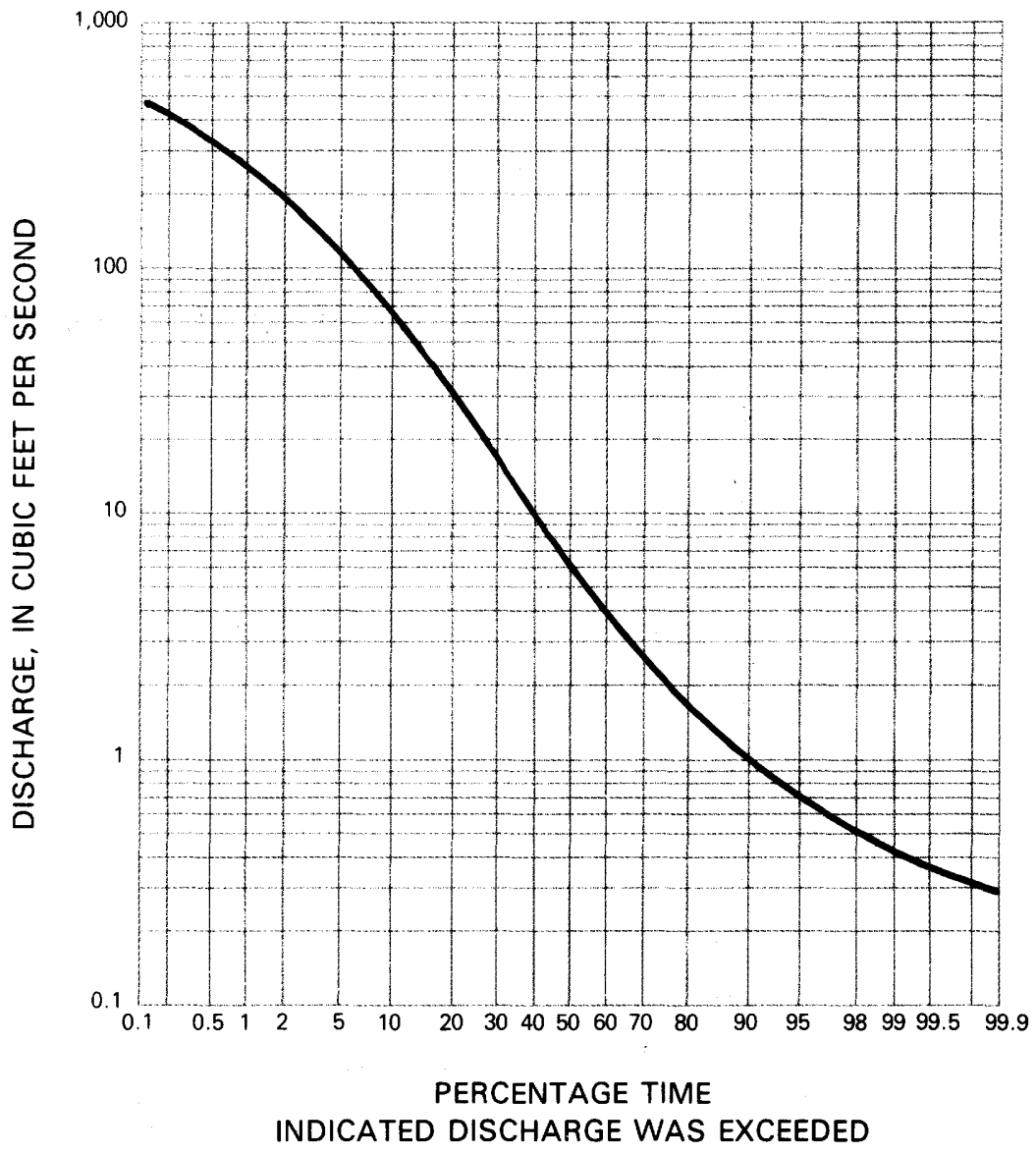



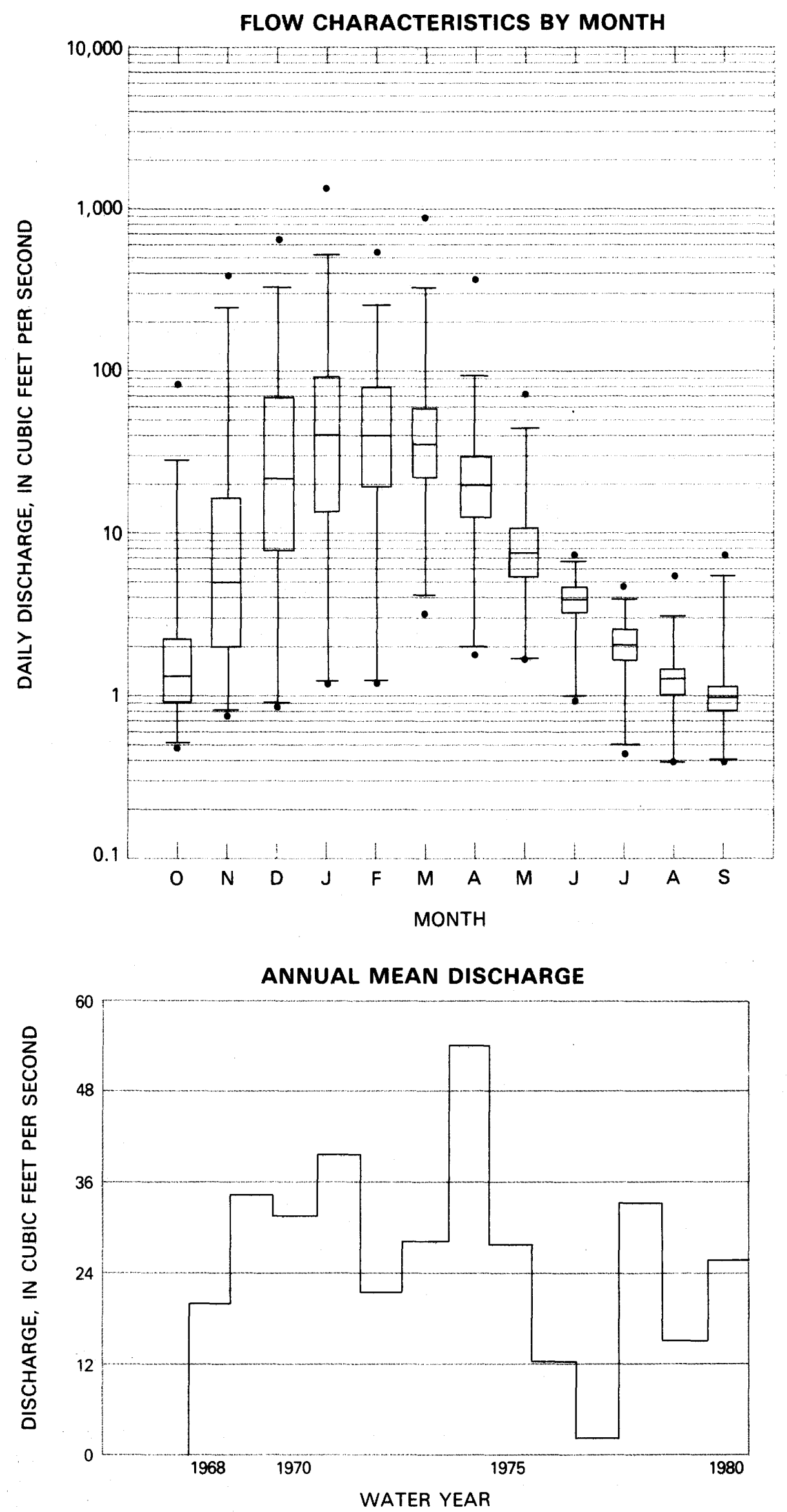
Station 8. - Merced River at Happy Isles Bridge near Yosemite, CA (11264500)

Location: Lat $37^{\circ} 43^{\prime} 54^{\prime \prime}$, long $119^{\circ} 33^{\prime} 28^{\prime \prime}$, Mariposa County, 2.0 mi southeast of Yosemite National Park headquarters.

Drainage area: $181 \mathrm{mi}^{2}$.

Topography: Alpine in character. The area has strongly glaciated valleys heading in eroded cirques. Much of the central basin has broad valleys and meadows separated by steep-sided ridges. Basin elevations range from about 4,000 to 13,090 $\mathrm{ft} ; 10-12 \mathrm{mi}$ of the eastern divide exceeds $11,000 \mathrm{ft}$. About 99 percent of the basin lies above $6,000 \mathrm{ft}$.

Rock type: Almost entirely granite with small areas of alluvium in valley bottoms.

Vegetation: About 45 percent of the basin is bush covered or forested with fir, pine, and some sequoias. Many peaks and ridges rise above timberline.

Manmade influences: The basin lies completely within Yosemite National Park. An annual average of approximately $1 \mathrm{ft}^{3} / \mathrm{s}$ is diverted above the gage for use in Yosemite Valley.

Period of record: August 1915 to September 1980.

Average discharge: $344 \mathrm{ft}^{3} / \mathrm{s}$.

Extremes: Maximum discharge, 9,860 ft $\mathrm{ft}^{3} / \mathrm{s}$, December 23, 1955, gage height, $12.73 \mathrm{ft}$, from rating curve extended above $4,000 \mathrm{ft}^{3} / \mathrm{s}$ on basis of contracted-opening measurements at gage heights $10.4 \mathrm{ft}$ and $11.55 \mathrm{ft}$; minimum, $1.5 \mathrm{ft}^{3} / \mathrm{s}$, September 30, 1926, September 26, 1977.

Serial correlation coefficient for annual mean discharges: -0.137 .

Kendall's tau correlation coefficient for annual mean discharges: 0.029 .

\begin{tabular}{|c|rrrrr|}
\hline \multicolumn{6}{|c|}{ FLOOD FREQUENCY } \\
\hline \multicolumn{4}{|c|}{$\begin{array}{c}\text { Peak discharge, in cubic feet per second, for } \\
\text { indicated recurrence interval, in years }\end{array}$} \\
\hline $\begin{array}{c}\text { R. I. } \\
\text { Discharge }\end{array}$ & 2 & 5 & 10 & 50 & 100 \\
\hline
\end{tabular}

Standard Deviation (logs): 0.209

Skewness Coefficient (logs): 0.392

\begin{tabular}{|r|rrrrr|}
\hline \multicolumn{5}{|c|}{ LOW-FLOW FREQUENCY } \\
\hline $\begin{array}{r}\text { Consecutive } \\
\text { day period }\end{array}$ & \multicolumn{4}{|c|}{$\begin{array}{l}\text { Discharge, in cubic feet per second for } \\
\text { indicated recurrence interval, in years }\end{array}$} \\
\hline & \multicolumn{1}{|c}{2} & 5 & 10 & 50 & 100 \\
\cline { 2 - 6 } 7 & 6.6 & 3.5 & 2.6 & 1.5 & 1.2 \\
14 & 7.2 & 3.8 & 2.8 & 1.6 & 1.3 \\
30 & 8.9 & 4.6 & 3.3 & 1.8 & 1.5 \\
60 & 12.7 & 6.5 & 4.5 & 2.4 & 2.0 \\
90 & 17.4 & 8.9 & 6.3 & 3.3 & 2.7 \\
\hline
\end{tabular}

\section{FLOW DURATION}

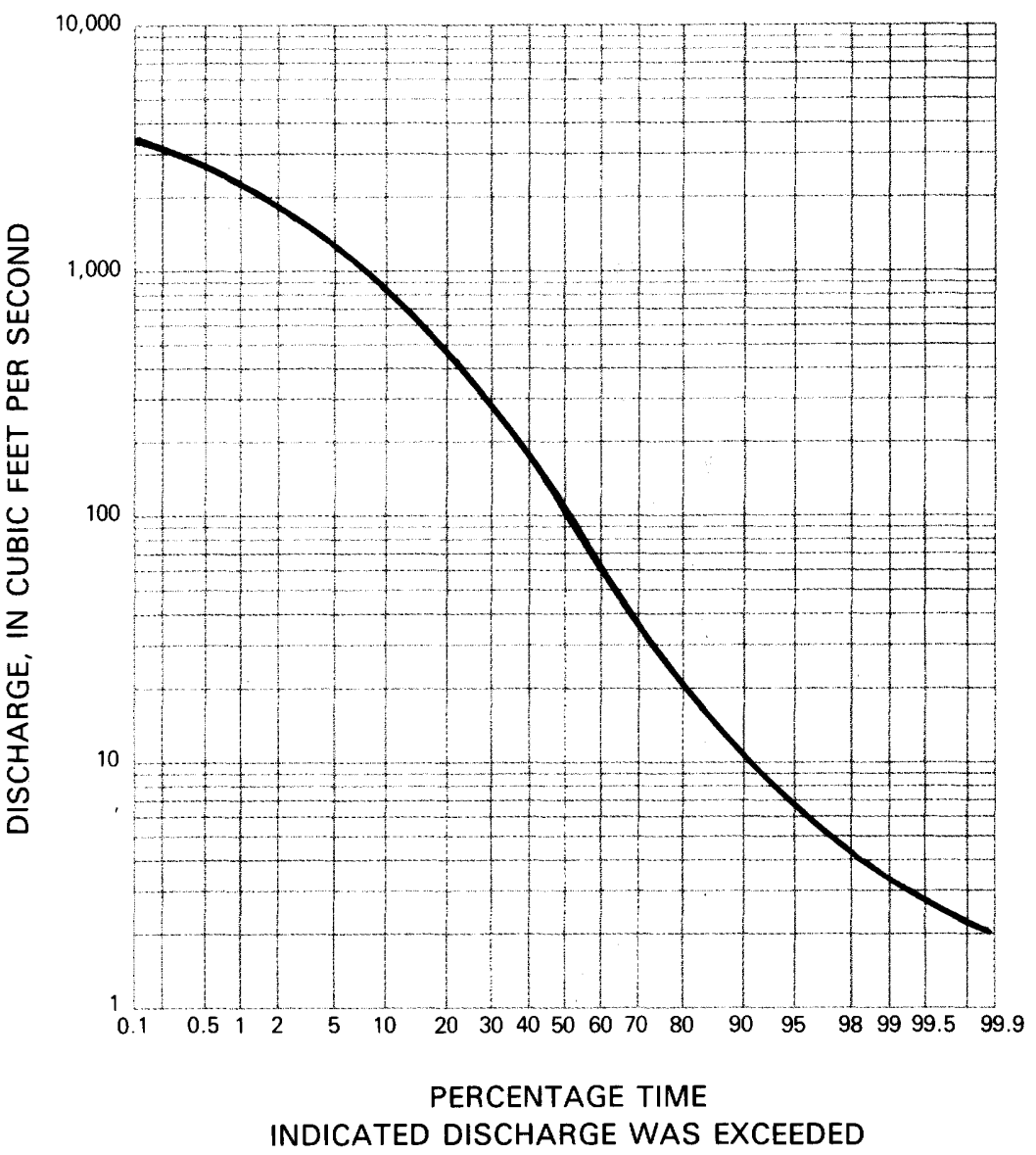



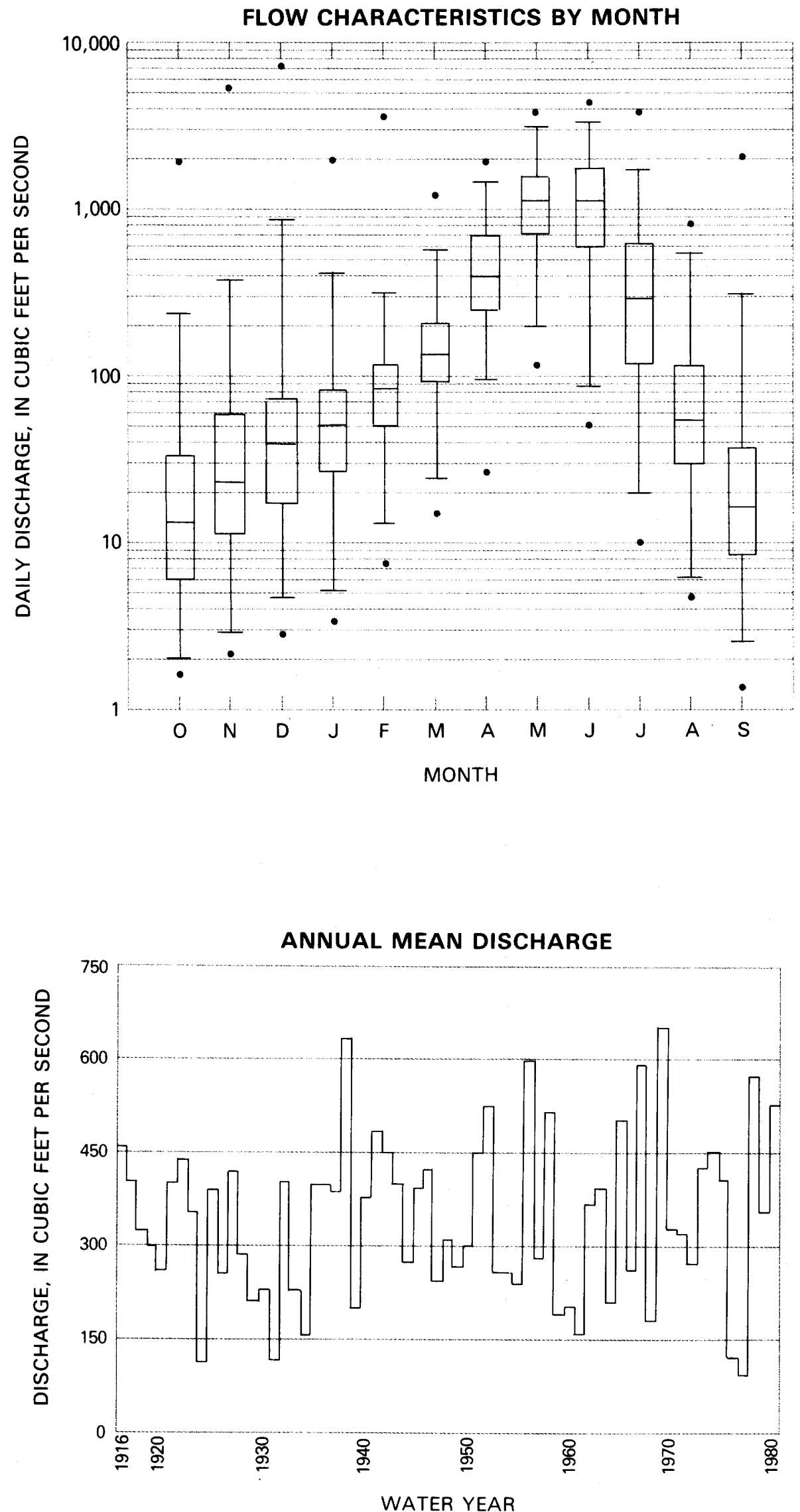
Station 9. - Halfmoon Creek near Malta, CO (07083000)

Location: Lat $39^{\circ} 10^{\prime} 20^{\prime \prime}$, long $106^{\circ} 23^{\prime} 19^{\prime \prime}$, Lake County, 4.3 mi southwest of Malta.

Drainage area: $23.6 \mathrm{mi}^{2}$.

Topography: Mountainous and having steep slopes. Basin elevations range from 9,740 to $14,430 \mathrm{ft}$. Stream slopes range from $2,000 \mathrm{ft} / \mathrm{mi}$ in the upper reaches to $100 \mathrm{ft} / \mathrm{mi}$ at the gage.

Rock type: The upper basin is underlain by schist and the lower basin is composed of morainal material.

Vegetation: The lower part of the basin is forested with lodgepole pine, Engelmann spruce, and fir. Much of the upper basin is above timberline.

Manmade influences: Parts of the basin have been burned over. Heavy use during the summer months by hikers and campers is not hydrologically significant. There are a few residents in the basin, which is entirely within the San Isabel National Forest.

Period of record: July 1946 to September 1980.

Average discharge: $28.4 \mathrm{ft}^{3} / \mathrm{s}$.

Extremes: Maximum discharge, $450 \mathrm{ft}^{3} / \mathrm{s}$, June 30,1957 , gage height, $3.48 \mathrm{ft}$, site and datum then in use; minimum not determined.

Serial correlation coefficient for annual mean discharges: -0.021 .

Kendall's tau correlation coefficient for annual mean discharges: -0.041 .

\section{FLOW DURATION}

\begin{tabular}{|c|rrrrr|}
\hline \multicolumn{6}{|c|}{ FLOOD FREQUENCY } \\
\hline \multicolumn{5}{|c|}{$\begin{array}{l}\text { Peak discharge, in cubic feet per second, for } \\
\text { indicated recurrence interval, in years }\end{array}$} \\
\hline $\begin{array}{c}\text { R. I. } \\
\text { Discharge }\end{array}$ & 26 & 5 & 10 & 50 & 100 \\
\hline
\end{tabular}

Standard Deviation (logs): 0.151

Skewness Coefficient (logs): -0.522

\begin{tabular}{|c|ccccc|}
\hline \multicolumn{5}{|c|}{ LOW-FLOW FREQUENCY } \\
\hline $\begin{array}{c}\text { Consecutive } \\
\text { day period }\end{array}$ & \multicolumn{4}{|c|}{$\begin{array}{l}\text { Discharge, in cubic feet per second for } \\
\text { indicated recurrence interval, in years }\end{array}$} \\
\hline & 2 & 5 & 10 & 50 & 100 \\
\cline { 2 - 6 } 7 & 2.5 & 1.9 & 1.6 & 1.1 & 1.0 \\
14 & 2.7 & 2.0 & 1.6 & 1.2 & 1.0 \\
30 & 3.0 & 2.1 & 1.7 & 1.2 & 1.1 \\
60 & 3.2 & 2.4 & 2.0 & 1.5 & 1.3 \\
90 & 3.5 & 2.6 & 2.2 & 1.7 & 1.5 \\
\hline
\end{tabular}

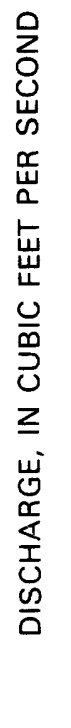

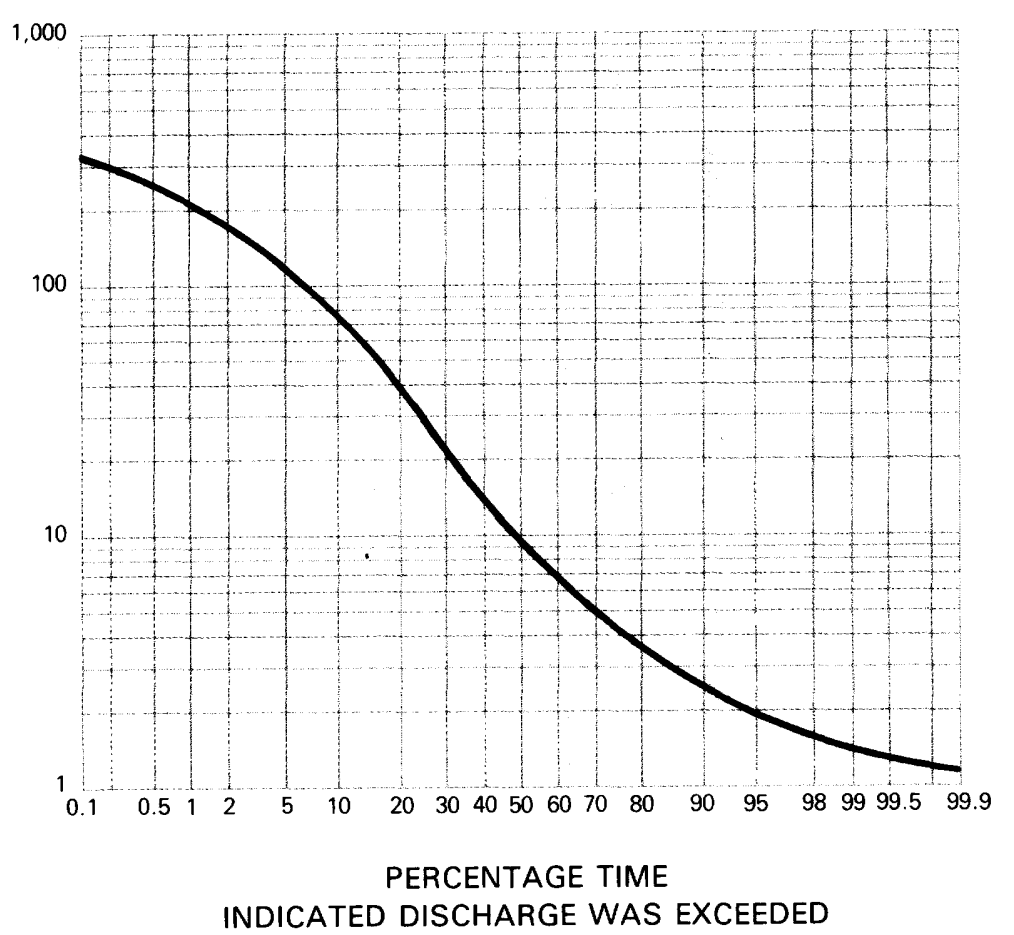



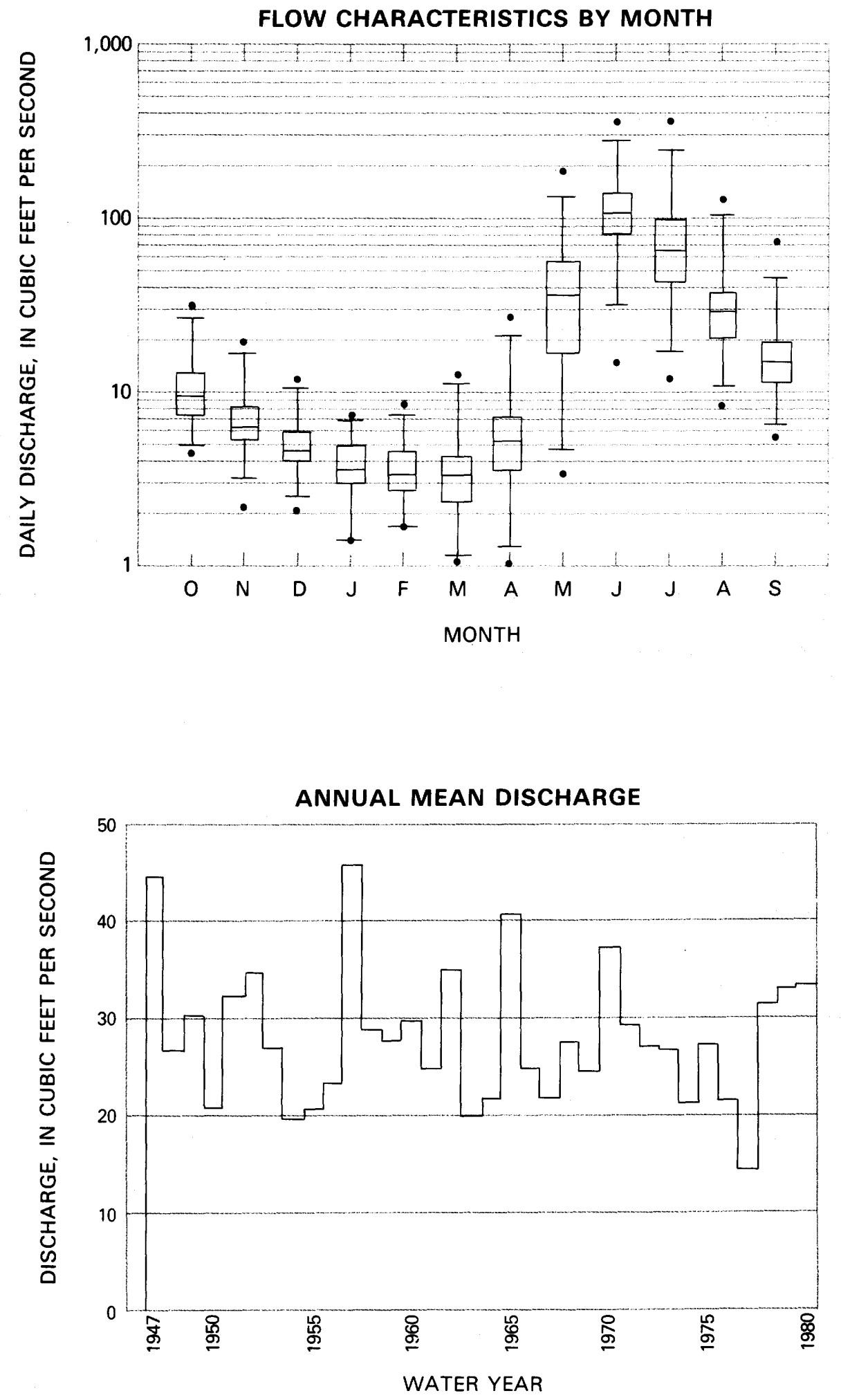
Station 10. - Vallecito Creek near Bayfield, CO (09352900)

Location: Lat $37^{\circ} 28^{\prime} 39^{\prime \prime}$, long $107^{\circ} 32^{\prime} 35^{\prime \prime}$, La Plata County, 18 mi north of Bayfield.

Drainage area: $72.1 \mathrm{mi}^{2}$.

Topography: Very mountainous and having steep slopes. Basin elevations range from 7,900 to $14,084 \mathrm{ft}$. The slope of the main stream is about $175 \mathrm{ft} / \mathrm{mi}$.

Rock type: The basin is underlain by metamorphic rocks.

Vegetation: The basin is predominantly forested with Engelmann spruce and also contains scattered aspen groves. Parts of the basin are above the timberline.

Manmade influences: The basin lies entirely within a wilderness area and continues being preserved in its natural state. Cloud-seeding has occurred over the basin.

Period of record: October 1962 to September 1980.

Average discharge: $141 \mathrm{ft}^{3} / \mathrm{s}$.

Extremes: Maximum discharge, 7,050 ft $3 / \mathrm{s}$, September 6, 1970, gage height, $5.51 \mathrm{ft}$ from water-stage recorder, 6.76 $\mathrm{ft}$ from floodmarks, from rating curve extended above $1,400 \mathrm{ft}^{3} / \mathrm{s}$ on basis of slope-area measurement of peak flow; minimum daily, $6.7 \mathrm{ft}^{3} / \mathrm{s}$, December 28,1976 .

Serial correlation coefficient for annual mean discharges: -0.210 .

Kendall's tau correlation coefficient for annual mean discharges: 0.150 .

\section{FLOW DURATION}

\begin{tabular}{|c|rrrr|}
\hline \multicolumn{4}{|c|}{ FLOOD FREQUENCY } \\
\hline \multicolumn{4}{|c|}{$\begin{array}{c}\text { Peak discharge, in cubic feet per second, for } \\
\text { indicated recurrence interval, in years }\end{array}$} \\
\hline R. I. & 2 & 5 & 10 & 25 \\
Discharge & 1,180 & 1,890 & 2,460 & 3,330 \\
\hline
\end{tabular}

Standard Deviation (logs): 0.228

Skewness Coefficient (logs): 0.438

\begin{tabular}{|c|cccc|}
\hline \multicolumn{4}{|c|}{ LOW-FLOW FREQUENCY } \\
\hline $\begin{array}{c}\text { Consecutive } \\
\text { day period }\end{array}$ & \multicolumn{3}{|c|}{$\begin{array}{l}\text { Discharge, in cubic feet per second for } \\
\text { indicated recurrence interval, in years }\end{array}$} \\
\hline & 2 & 5 & 10 & 20 \\
\cline { 2 - 5 } 7 & 14.1 & 11.1 & 9.7 & 8.6 \\
14 & 15.1 & 11.7 & 10.2 & 9.0 \\
30 & 15.9 & 12.5 & 10.9 & 9.7 \\
60 & 16.7 & 13.0 & 11.3 & 9.9 \\
90 & 18.1 & 13.8 & 11.8 & 10.3 \\
\hline
\end{tabular}

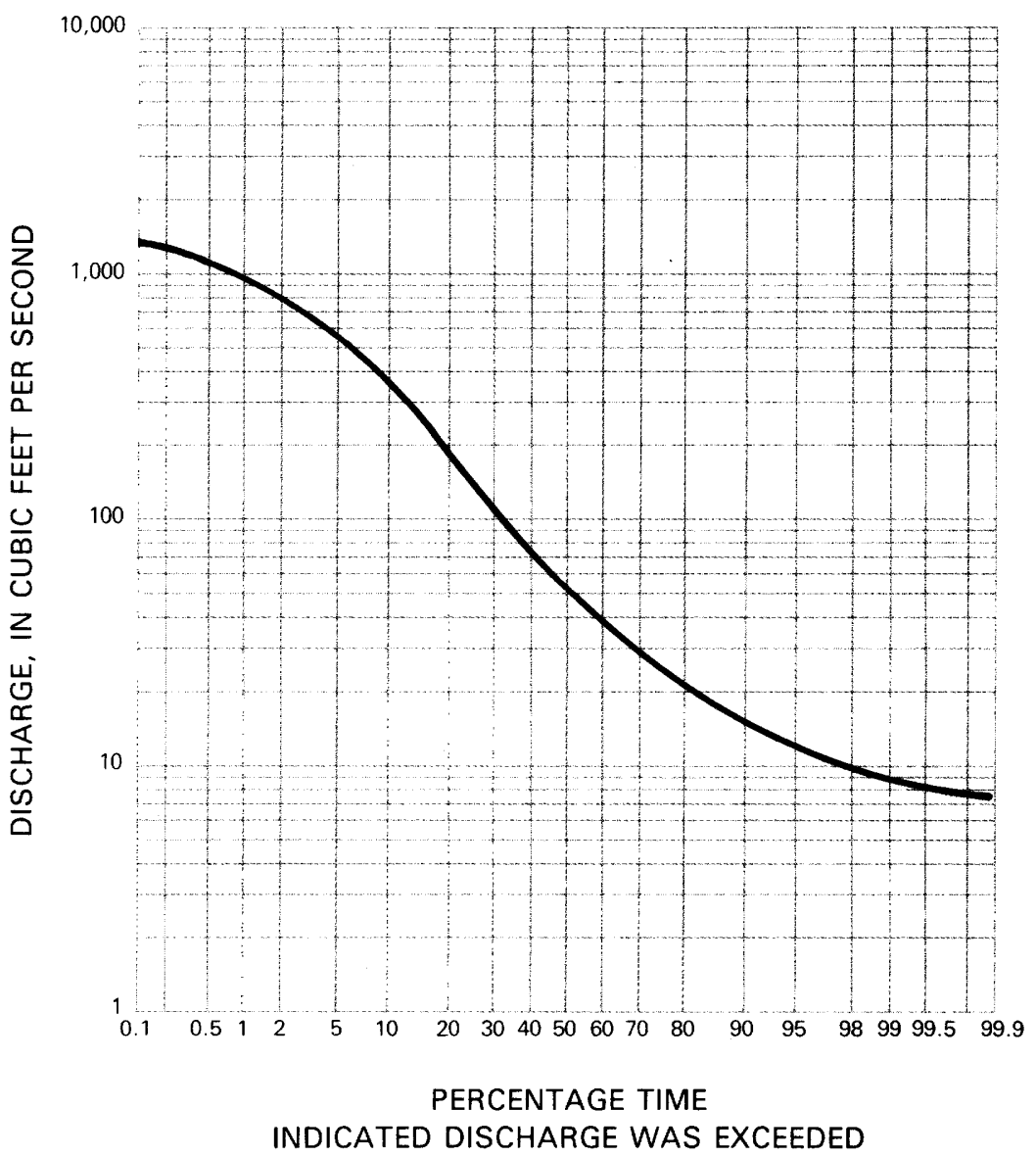



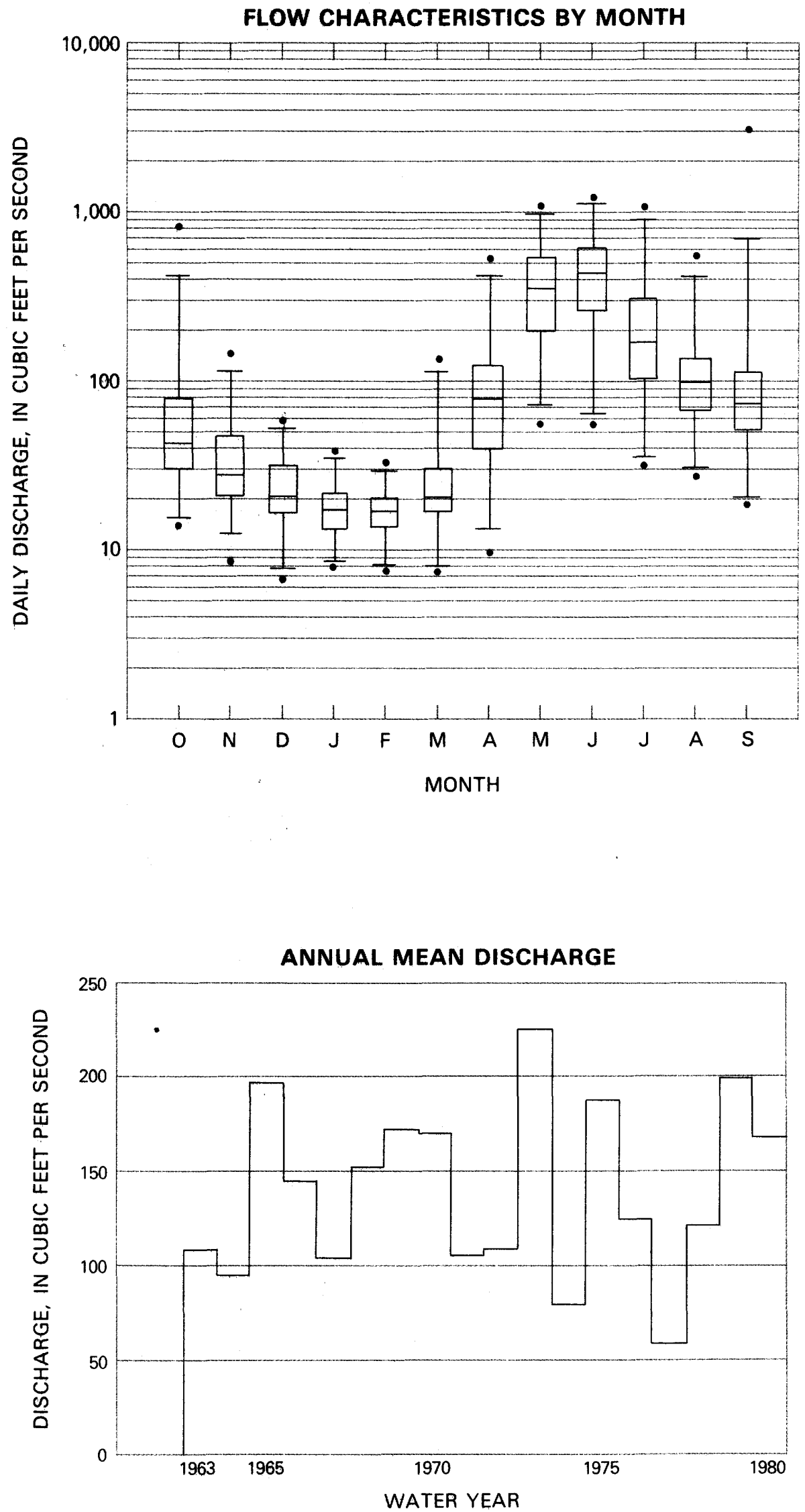
Station 11. - Sopchoppy River near Sopchoppy, FL (02327100)

Location: Lat $30^{\circ} 07^{\prime} 45^{\prime \prime}$, long $84^{\circ} 29^{\prime} 40^{\prime \prime}$, Wakulla County, 4.7 mi north of Sopchoppy.

Drainage area: $102 \mathrm{mi}^{2}$.

Topography: The basin contains numerous swamps, sloughs, and some small ponds. The drainage slopes rather uniformly downward from north to south. Basin elevations range from 50 to $110 \mathrm{ft}$.

Rock type: Sandy limestone.

Vegetation: Dense cypress swamps separated by sandy soil heavily covered by slash pines, scrub oaks, and undergrowth such as palmetto.

Manmade influences: The basin is located in the Apalachicola National Forest. Several service roads and fire breaks traverse the basin. Controlled cutting in small tracts of pine trees for pulp is practiced.

Period of record: June 1964 to September 1980.

Average discharge: $197 \mathrm{ft}^{3} / \mathrm{s}$.

Extremes: Maximum discharge, 5,260 ft $\mathrm{t}^{3} / \mathrm{s}$, July 31, 1975, gage height, $34.47 \mathrm{ft}$ from rating curve extended above 3,500 $\mathrm{ft}^{3} / \mathrm{s}$ by velocity-area study; minimum, $1.0 \mathrm{ft}^{3} / \mathrm{s}$, June 29 to July 3, 1968; minimum gage height, $7.94 \mathrm{ft}$, June 4, 5, 1965.

Serial correlation coefficient for annual mean discharges: -0.138 .

Kendall's tau correlation coefficient for annual mean discharges: 0.017 .

\section{FLOW DURATION}

\begin{tabular}{|c|rrrr|}
\hline \multicolumn{5}{|c|}{ FLOOD FREQUENCY } \\
\hline \multicolumn{4}{|c|}{ Peak discharge, in cubic feet per second, for } \\
indicated recurrence interval, in years \\
\hline R. I. & 2 & 5 & 10 & 25 \\
Discharge & 2,300 & 3,620 & 4,530 & 5,680 \\
\hline
\end{tabular}

Standard Deviation (logs): 0.244

Skewness Coefficient (logs): -0.273

\begin{tabular}{|c|rccc|}
\hline \multicolumn{5}{|c|}{ LOW-FLOW FREQUENCY } \\
\hline $\begin{array}{l}\text { Consecutive } \\
\text { day period }\end{array}$ & \multicolumn{3}{|c|}{$\begin{array}{l}\text { Discharge, in cubic feet per second for } \\
\text { indicated recurrence interval, in years }\end{array}$} \\
\hline & \multicolumn{1}{|c|}{2} & 5 & 10 & 20 \\
\cline { 2 - 5 } 7 & 2.4 & 1.6 & 1.4 & 1.2 \\
14 & 2.8 & 1.8 & 1.5 & 1.3 \\
30 & 3.4 & 2.2 & 1.8 & 1.6 \\
60 & 7.4 & 3.4 & 2.4 & 1.9 \\
90 & 21.0 & 7.7 & 4.6 & 3.0 \\
\hline
\end{tabular}

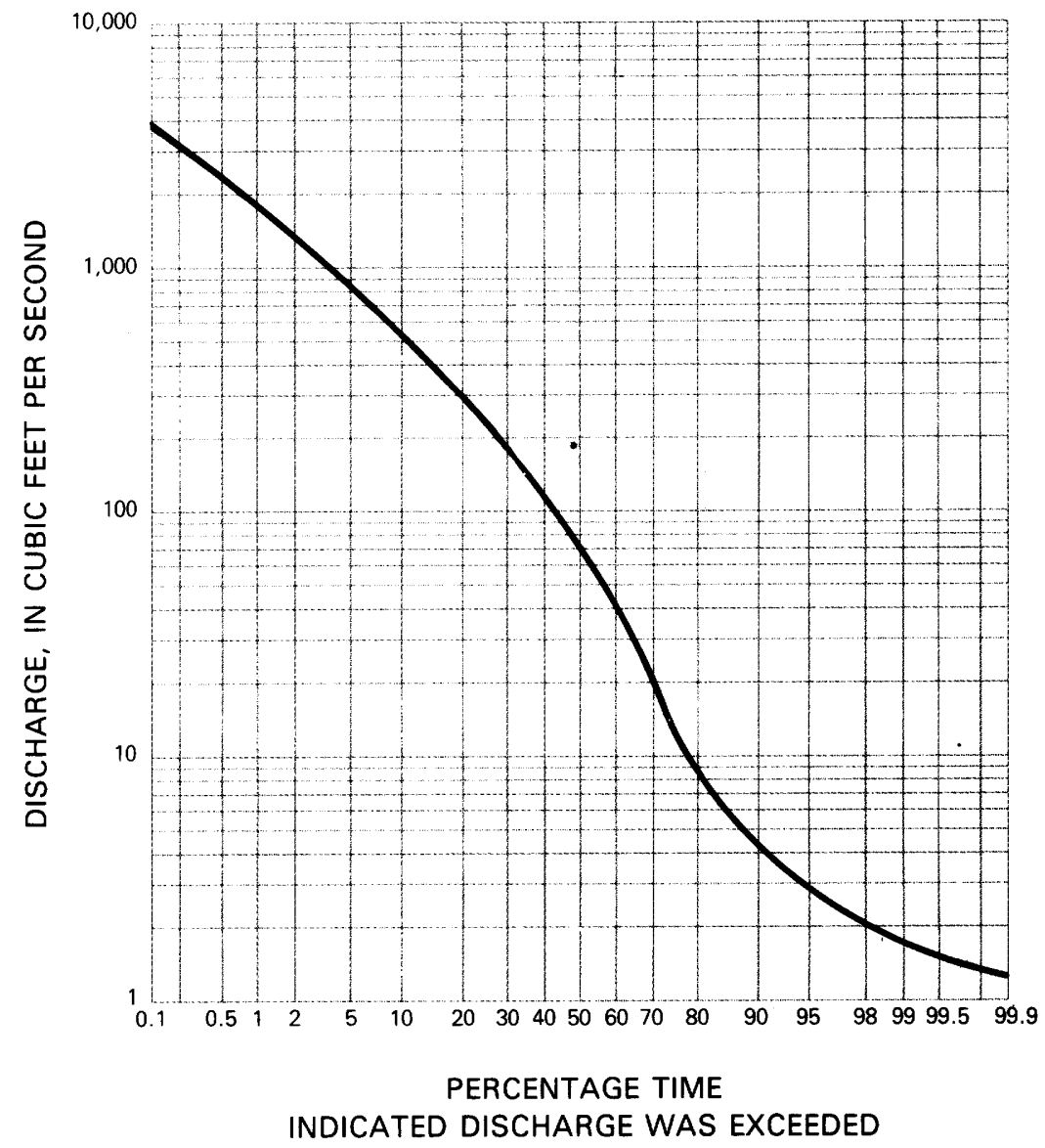



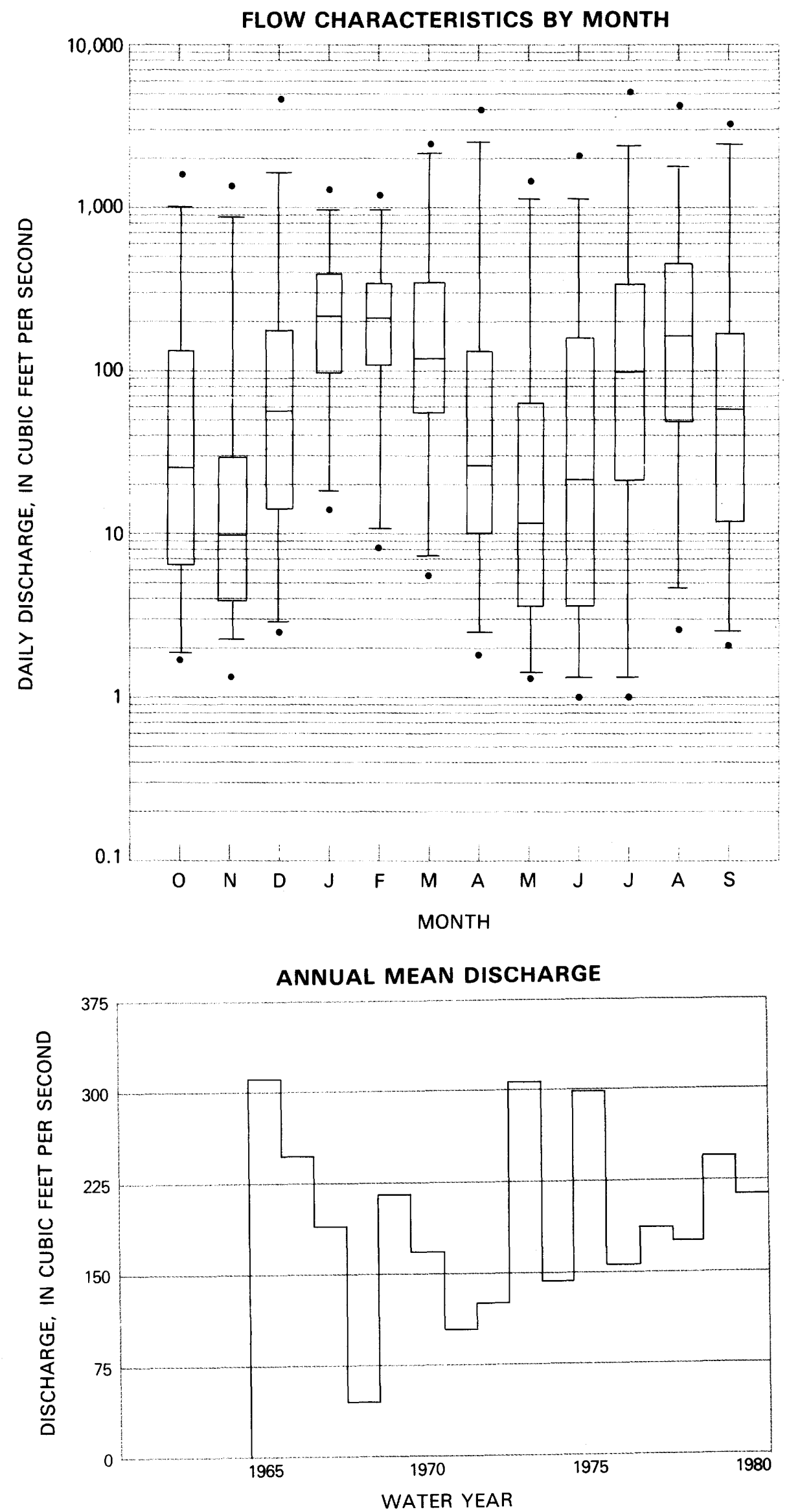
Station 12. - Falling Creek near Juliette, GA (02212600)

Location: Lat $33^{\circ} 05^{\prime} 59^{\prime \prime}$, long $83^{\circ} 43^{\prime} 25^{\prime \prime}$, Jones County, 5.1 mi east of Juliette.

Drainage area: $72.2 \mathrm{mi}^{2}$.

Topography: Rolling hills. The general elevation of the divide is about $630 \mathrm{ft}$. Basin elevations range from 370 to 700 $\mathrm{ft}$. The slope of the main stream is about $33 \mathrm{ft} / \mathrm{mi}$.

Rock type: Gneiss and schist.

Vegetation: The basin is covered with second-growth pine mixed with a few hardwoods except for a few small cleared areas in the vicinity of houses.

Manmade influences: A few secondary roads are in the basin. There are several ponds in the basin, but storage is not sufficient to significantly affect runoff. Also in the basin are a few quarries, a gravel pit, and a few houses, none of which should significantly affect streamflow. Most of the basin lies within the Oconee National Forest where controlled logging is practiced. The remainder of the basin lies within the Piedmont National Wildlife Refuge.

Period of record: July 1964 to September 1980.

Average discharge: $68.5 \mathrm{ft}^{3} / \mathrm{s}$.

Extremes: Maximum discharge, 7,700 ft $\mathrm{ft}^{3} / \mathrm{s}$, March 2, 1971, gage height, $23.0 \mathrm{ft}$, from floodmark; minimum, $0.14 \mathrm{ft}^{3} / \mathrm{s}$, September 29, 30, 1972.

Serial correlation coefficient for annual mean discharges: 0.347 .

Kendall's tau correlation coefficient for annual mean discharges: 0.067 .

\begin{tabular}{|c|rrrr|}
\hline \multicolumn{5}{|c|}{ FLOOD FREQUENCY } \\
\hline \multicolumn{4}{|c|}{$\begin{array}{l}\text { Peak discharge, in cubic feet per second, for } \\
\text { indicated recurrence interval, in years }\end{array}$} \\
\hline R. I. & 2 & 5 & 10 & 25 \\
Discharge & 3,200 & 5,120 & 6,480 & 8,270 \\
\hline
\end{tabular}

Standard Deviation (logs): 0.249

Skewness Coefficient (logs): -0.182

\begin{tabular}{|c|cccc|}
\hline \multicolumn{5}{|c|}{ LOW-FLOW FREQUENCY } \\
\hline $\begin{array}{c}\text { Consecutive } \\
\text { day period }\end{array}$ & \multicolumn{2}{|c|}{$\begin{array}{l}\text { Discharge, in cubic feet per second for } \\
\text { indicated recurrence interval, in years }\end{array}$} \\
\hline & 2 & 5 & 10 & 20 \\
\cline { 2 - 5 } 7 & 3.5 & 1.2 & 0.7 & 0.4 \\
14 & 3.9 & 1.5 & 0.9 & 0.5 \\
30 & 5.4 & 2.3 & 1.4 & 0.9 \\
60 & 7.8 & 3.4 & 2.1 & 1.4 \\
90 & 9.7 & 4.7 & 3.1 & 2.2 \\
\hline
\end{tabular}

FLOW DURATION

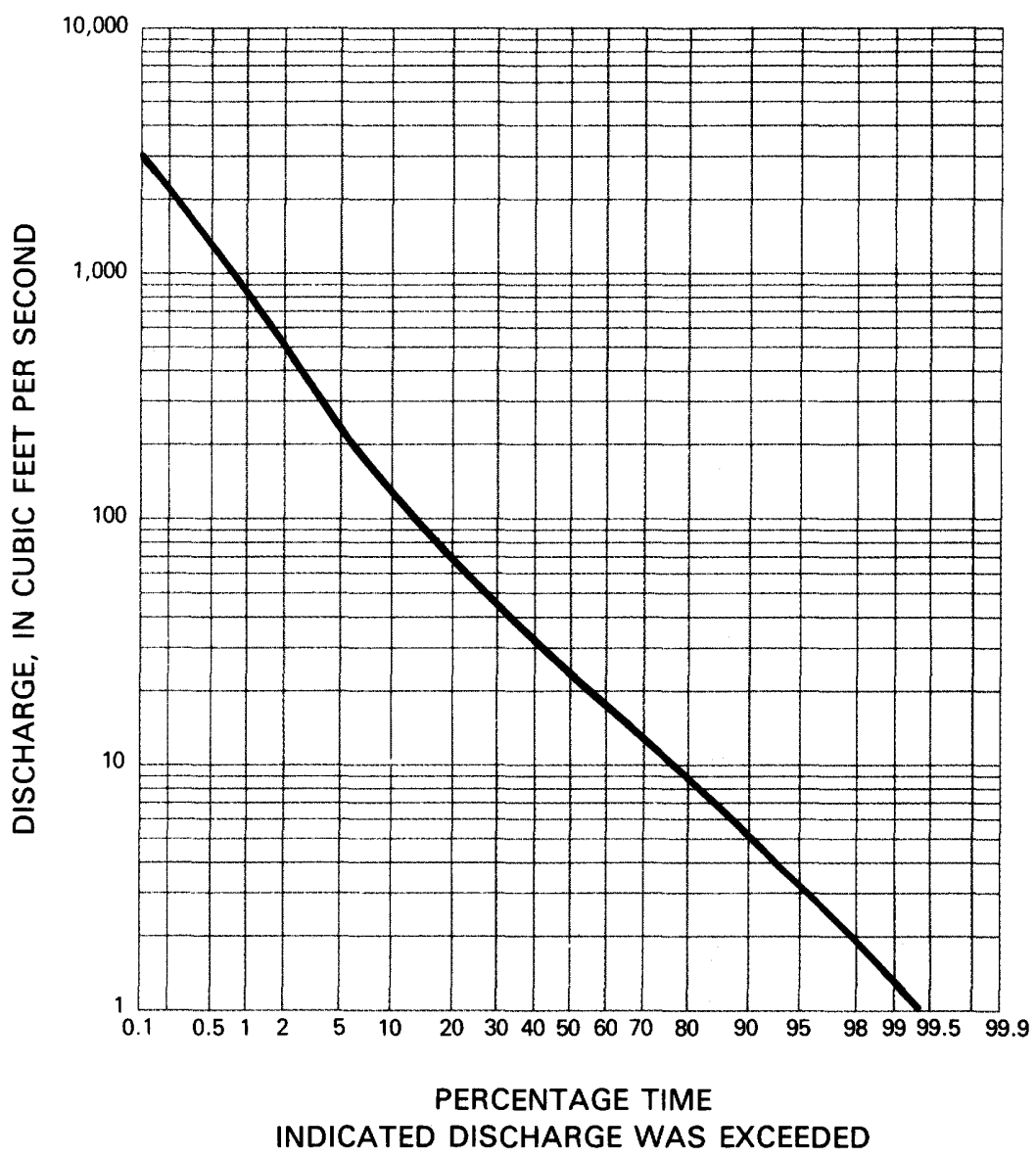



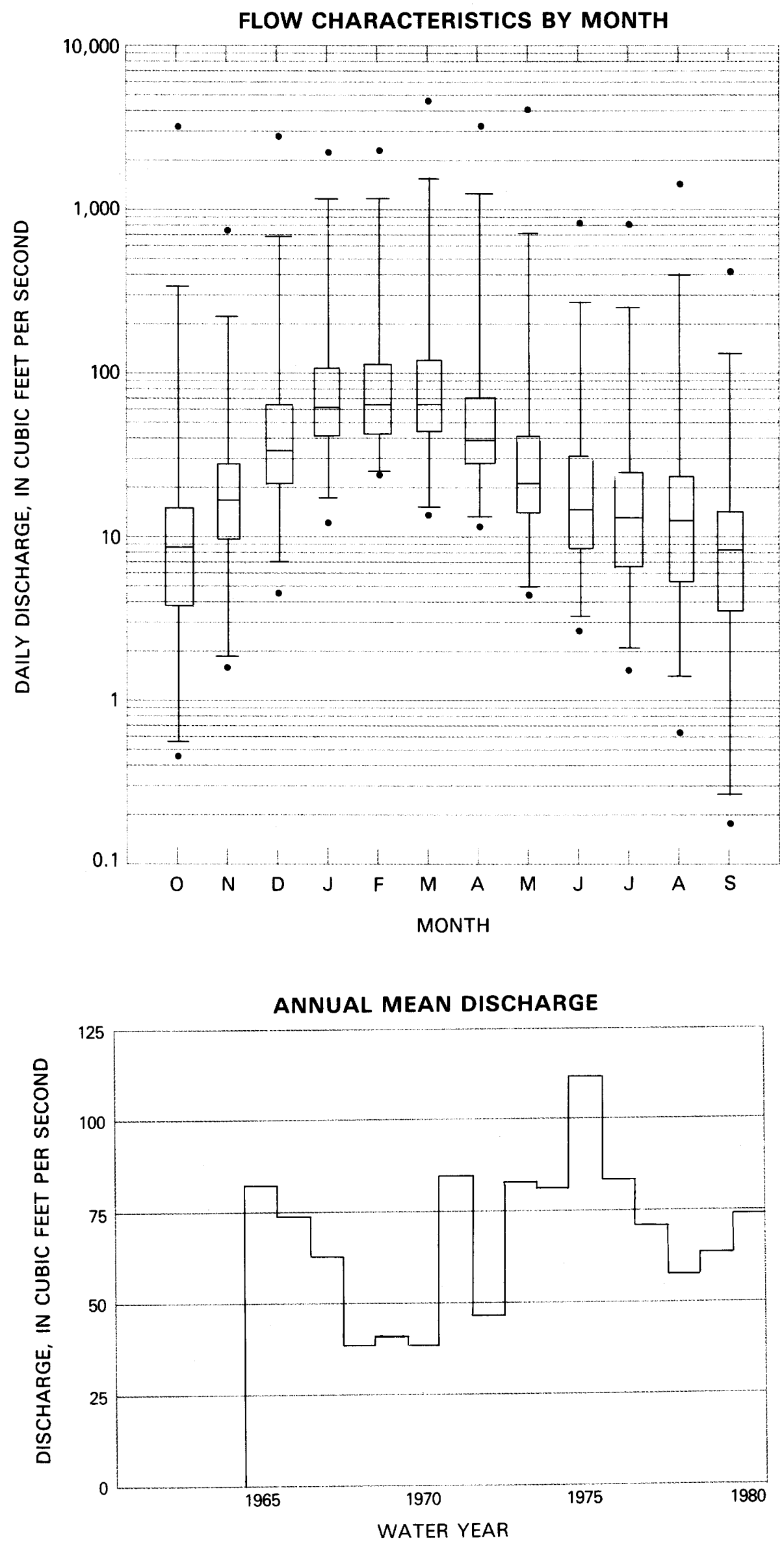
Station 13. - Tallulah River near Clayton, GA (02178400)

Location: Lat $34^{\circ} 53^{\prime} 25^{\prime \prime}$, long $83^{\circ} 31^{\prime} 50^{\prime \prime}$, Rabun County, 10.3 mi west of Clayton.

Drainage area: $56.5 \mathrm{mi}^{2}$.

Topography: Rugged terrain. The general elevation of the divide is about $3,500 \mathrm{ft}$. Basin elevations range from 1,880 to $5,500 \mathrm{ft}$. The slope of the main stream is about $375 \mathrm{ft} / \mathrm{mi}$.

Rock type: Gneiss and schist.

Vegetation: The basin is covered by a mixture of second growth white pine, hardwood, and laurel.

Manmade influences: The basin lies wholly within the Chattahoochee and Nantahala National Forests where special logging procedures are practiced. A few secondary roads traverse the basin.

Period of record: July 1964 to September 1980.

Average discharge: $208 \mathrm{ft}^{3} / \mathrm{s}$.

Extremes: Maximum discharge, $8,500 \mathrm{ft}^{3} / \mathrm{s}$, May 28, 1973, gage height, $12.00 \mathrm{ft}$; minimum discharge, $45 \mathrm{ft} 3 / \mathrm{s}$, September 25, 26, 1964.

Serial correlation coefficient for annual mean discharges: 0.311 .

Kendall's tau correlation coefficient for annual mean discharges: 0.283.

FLOW DURATION

\begin{tabular}{|c|rrrr|}
\hline \multicolumn{4}{|c|}{ FLOOD FREQUENCY } \\
\hline \multicolumn{4}{|c|}{$\begin{array}{c}\text { Peak discharge, in cubic feet per second, for } \\
\text { indicated recurrence interval, in years }\end{array}$} \\
\hline $\begin{array}{c}\text { R. I. } \\
\text { Discharge }\end{array}$ & 2 & 5 & 10 & 25 \\
\hline
\end{tabular}

Standard Deviation (logs): 0.234

Skewness Coefficient (logs): -0.249

\begin{tabular}{|c|cccc|}
\hline \multicolumn{4}{|c|}{ LOW-FLOW FREQUENCY } \\
\hline $\begin{array}{c}\text { Consecutive } \\
\text { day period }\end{array}$ & \multicolumn{3}{|c|}{$\begin{array}{l}\text { Discharge, in cubic feet per second for } \\
\text { indicated recurrence interval, in years }\end{array}$} \\
\hline & 2 & 5 & 10 & 20 \\
\cline { 2 - 5 } 7 & 64 & 56 & 53 & 51 \\
14 & 68 & 58 & 55 & 52 \\
30 & 76 & 63 & 58 & 55 \\
60 & 86 & 69 & 63 & 59 \\
90 & 95 & 78 & 70 & 65 \\
\hline
\end{tabular}

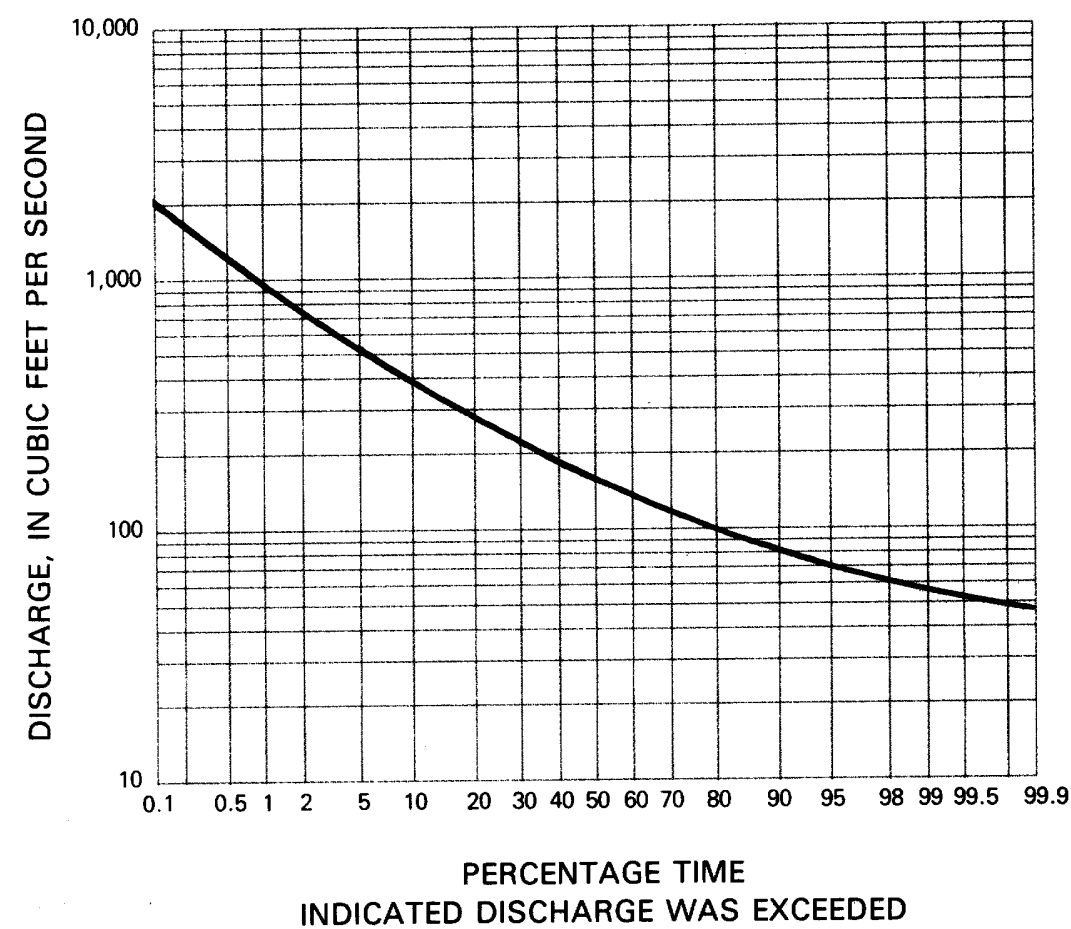



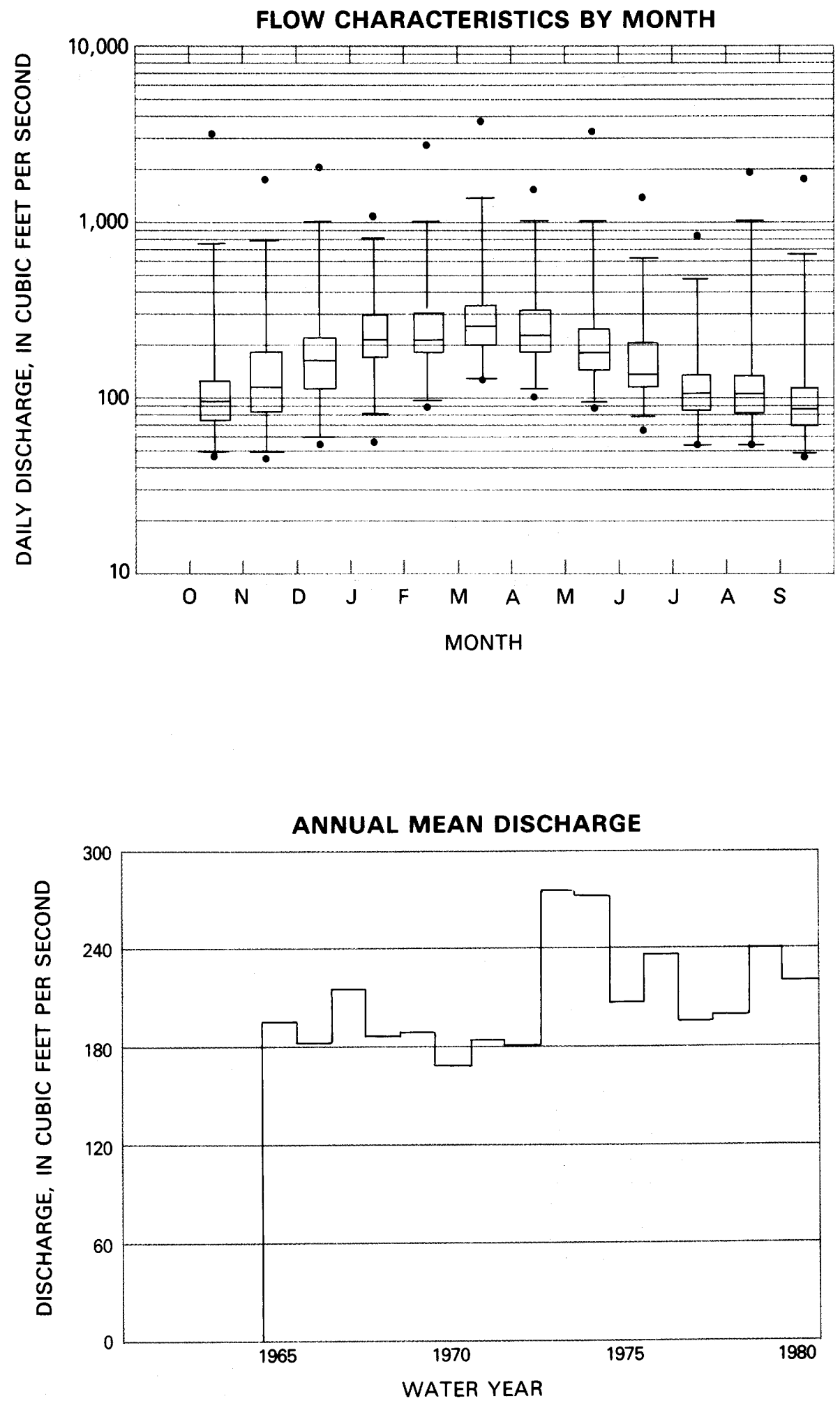
Station 14.-Honolii Stream near Papaikou, HI (16717000)

Location: Lat $19^{\circ} 46^{\prime} 00^{\prime \prime}$, long $155^{\circ} 09^{\prime} 16^{\prime \prime}$, Island of Hawaii, 4.1 mi west of Papaikou.

Drainage area: $11.6 \mathrm{mi}^{2}$.

Topography: The basin is composed of ridges and gulleys on the lower slope of Mauna Kea. Basin elevations range from 1,540 to $6,250 \mathrm{ft}$.

Rock type: Basalt.

Vegetation: Sparsely vegetated lava beds in the upper reaches and dense tropical vegetation in the lower reaches.

Manmade influences: No known significant influences to date. About 94 percent of the basin is in a State Forest Reserve.

Period of record: June 1911 to March 1913. February 1967 to September 1980.

Average discharge: $131 \mathrm{ft}^{3} / \mathrm{s}$.

Extremes: Maximum discharge, 22,600 ft $3 / \mathrm{s}$, May 23, 1978, gage height, $20.00 \mathrm{ft}$, from floodmarks and from rating curve extended above $4,610 \mathrm{ft}^{3} / \mathrm{s}$ on basis of slope-area measurement of gage height $20.00 \mathrm{ft}$; minimum, $0.8 \mathrm{ft}^{3} / \mathrm{s}$, January 31, 1912.

Serial correlation coefficient for annual mean discharges: -0.096 .

Kendall's tau correlation coefficient for annual mean discharges: 0.231 .

FLOW DURATION

\begin{tabular}{|c|rrrr|}
\hline \multicolumn{5}{|c|}{ FLOOD FREQUENCY } \\
\hline \multicolumn{4}{|c|}{ Peak discharge, in cubic feet per second, for } \\
indicated recurrence interval, in years \\
\hline R. I. & 2 & 5 & 10 & 25 \\
Discharge & 8,070 & 11,300 & 13,700 & 17,000 \\
\hline
\end{tabular}

Standard Deviation (logs): 0.165

Skewness Coefficient (logs): 0.421

\begin{tabular}{|r|rrrr|}
\hline \multicolumn{5}{|c|}{ LOW-FLOW FREQUENCY } \\
\hline $\begin{array}{l}\text { Consecutive } \\
\text { day period }\end{array}$ & \multicolumn{4}{|c|}{$\begin{array}{l}\text { Discharge, in cubic feet per second for } \\
\text { indicated recurrence interval, in years }\end{array}$} \\
\hline & 2 & 5 & 10 & 20 \\
\cline { 2 - 5 } 7 & 7.4 & 4.2 & 2.7 & 1.7 \\
14 & 9.6 & 5.7 & 3.8 & 2.4 \\
30 & 12.6 & 7.8 & 6.0 & 4.8 \\
60 & 19.6 & 11.6 & 8.9 & 7.1 \\
90 & 28.3 & 19.6 & 16.3 & 14.0 \\
\hline
\end{tabular}

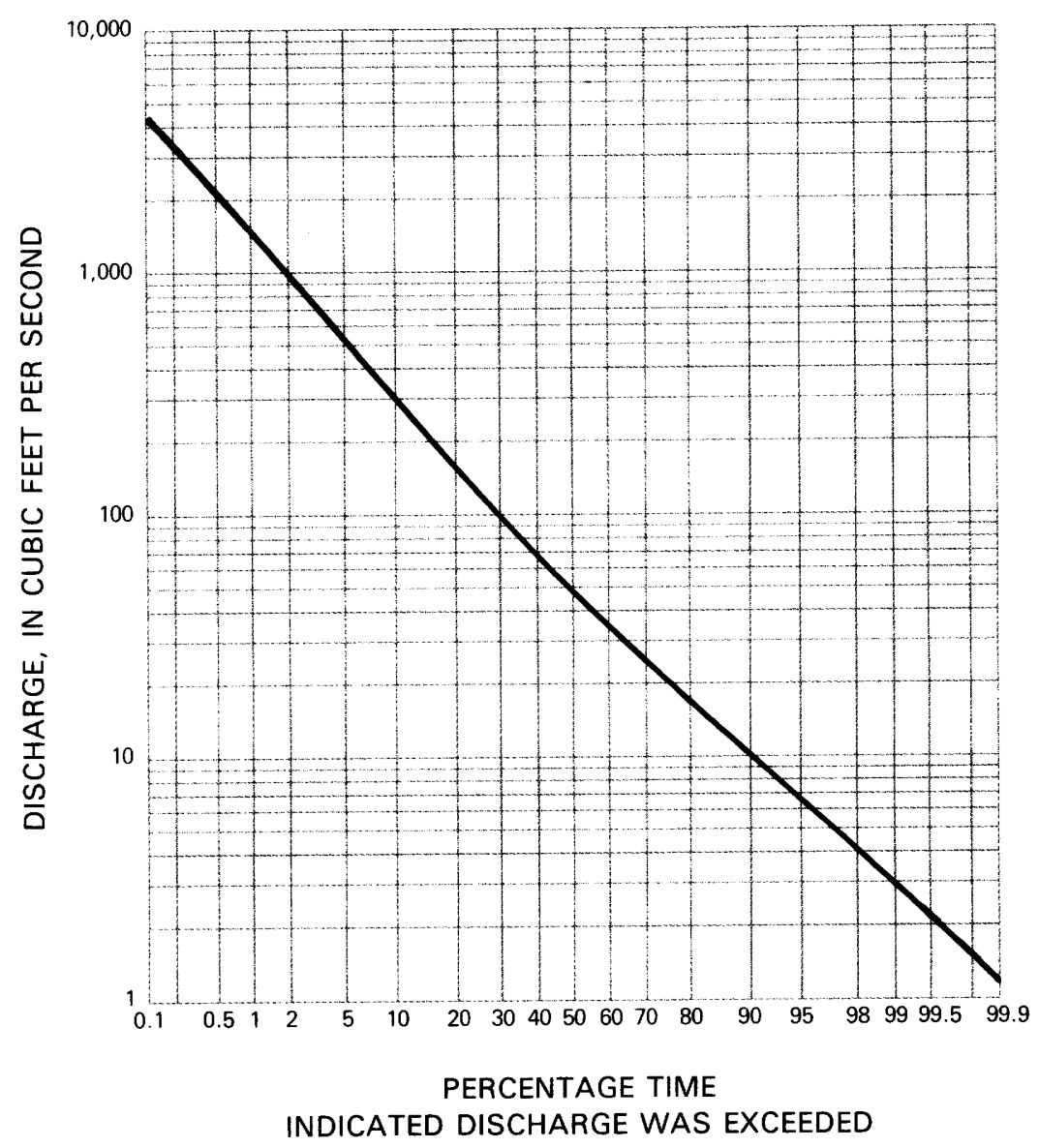



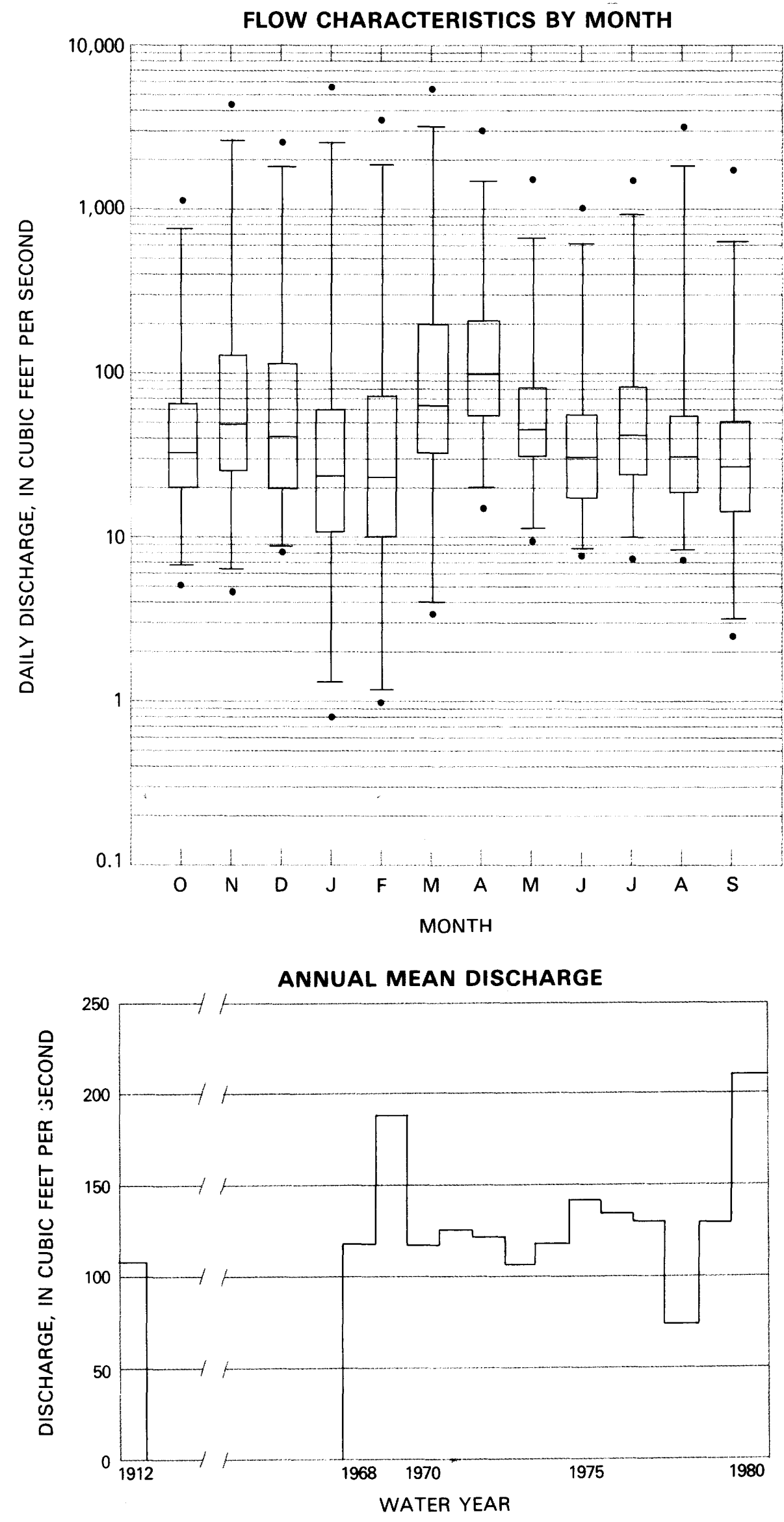
Station 15. - Big Jacks Creek near Bruneau, ID (13169500)

Location: Lat $42^{\circ} 47^{\prime} 06^{\prime \prime}$, long $115^{\circ} 59^{\prime} 00^{\prime \prime}$, Owyhee County, 11.5 mi southwest of Bruneau.

Drainage area: $253 \mathrm{mi}^{2}$.

Topography: Rolling hills. The general elevation of the divide is about $5,800 \mathrm{ft}$. Basin elevations range from 3,000 to $6,000 \mathrm{ft}$. The slope of the main stream is about $10 \mathrm{ft} / \mathrm{mi}$.

Rock type: The basin is underlain principally by silicic volcanic rocks consisting of rhyolite welded tuff. Basalt flows cap some of the higher tablelands. Stream channels contain a minor amount of alluvium.

Vegetation: The basin is covered by sagebrush and grass.

Manmade influences: The basin contains several stockponds. Undetermined acreages have been treated with herbicides, have had the brush removed, and the land seeded with crested wheatgrass. Periodic range fires, mostly small, have occurred. These factors are not significant to streamflow at the gage.

Period of record: December 1938 to October 1949, July 1965 to September 1980.

Average discharge: $4.0 \mathrm{ft}^{3} / \mathrm{s}$.

Extremes: Maximum discharge, 2,100 ft $3 \mathrm{f}^{3} \mathrm{~s}$, January 22, 1943, gage height, $12.4 \mathrm{ft}$, from high-water mark (site and datum then in use), on basis of slope-area measurement of peak flow; no flow for long periods each year.

Serial correlation coefficient for annual mean discharges: 0.198 .

Kendall's tau correlation coefficient for annual mean discharges: 0.193.

\begin{tabular}{|c|c|c|c|c|}
\hline \multicolumn{5}{|c|}{ LOW-FLOW FREQUENCY } \\
\hline $\begin{array}{l}\text { Consecutive } \\
\text { day period }\end{array}$ & \multicolumn{4}{|c|}{$\begin{array}{l}\text { Discharge, in cubic feet per second for } \\
\text { indicated recurrence interval, in years }\end{array}$} \\
\hline & 2 & 5 & 10 & 20 \\
\hline $\begin{array}{r}7 \\
14 \\
30 \\
60 \\
90\end{array}$ & & \multicolumn{3}{|c|}{$\begin{array}{l}\text { Long periods of no } \\
\text { flow for most years. }\end{array}$} \\
\hline
\end{tabular}

\begin{tabular}{|c|rrrr|}
\hline \multicolumn{5}{|c|}{ FLOOD FREQUENCY } \\
\hline \multicolumn{4}{|c|}{ Peak discharge, in cubic feet per second, for } \\
indicated recurrence interval, in years \\
\hline $\begin{array}{c}\text { R. I. } \\
\text { Discharge }\end{array}$ & 2 & 5 & 10 & 25 \\
\hline
\end{tabular}

Standard Deviation (logs): 0.610

Skewness Coefficient (logs): -0.550

\section{FLOW DURATION}

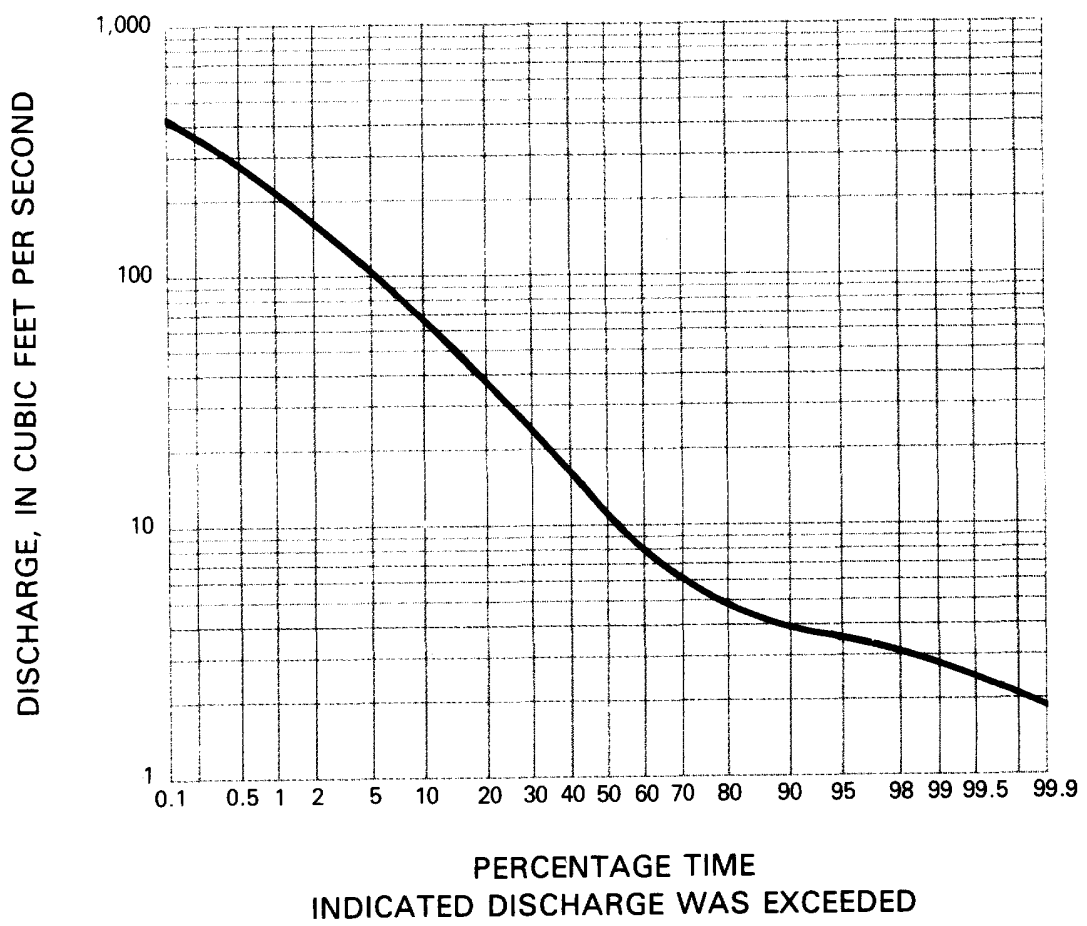



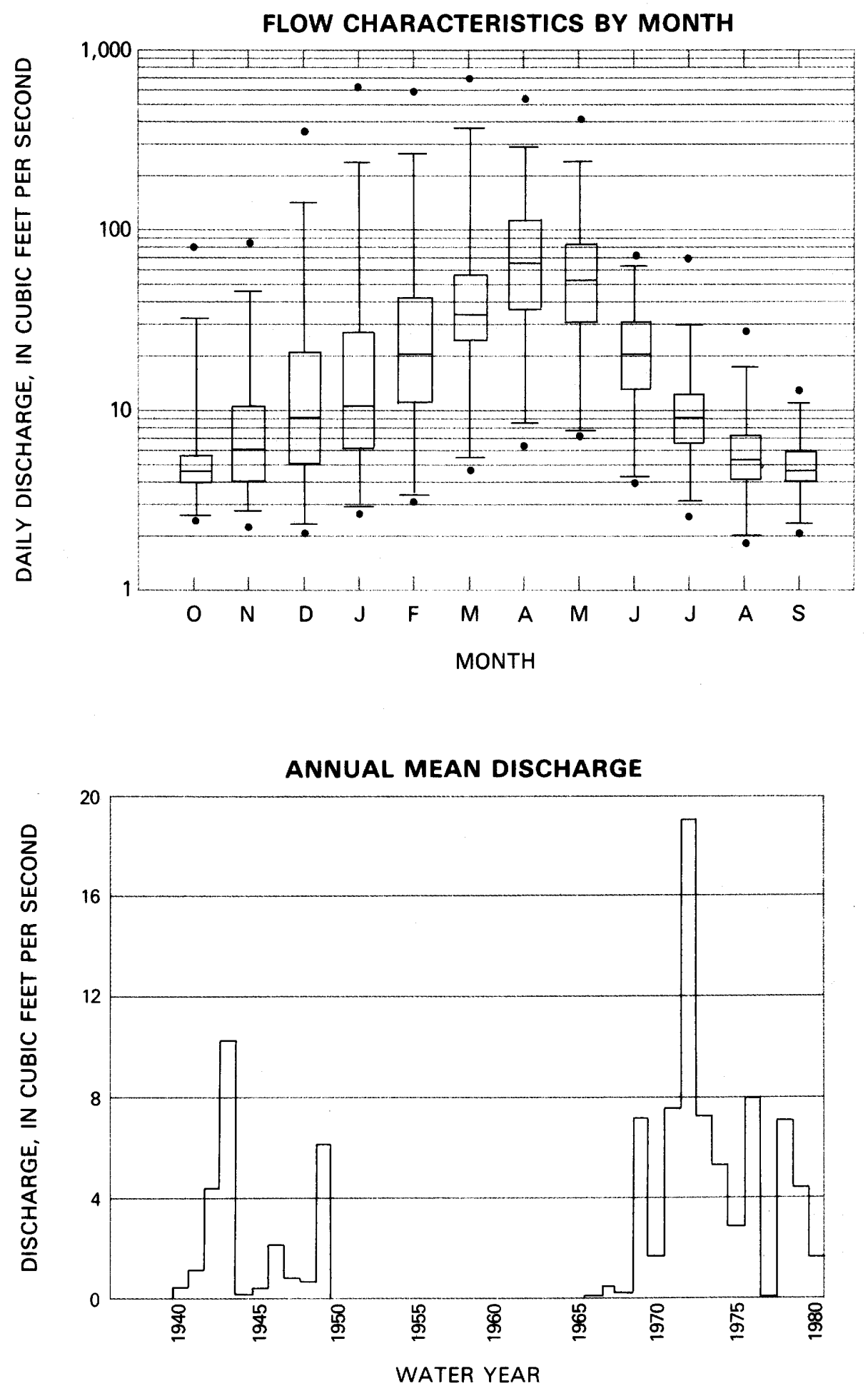
Station 16. - Hayden Creek below North Fork near Hayden Lake, ID (12416000)

Location: Lat $47^{\circ} 49^{\prime} 22^{\prime \prime}$, long $116^{\circ} 39^{\prime} 10^{\prime \prime}$, Kootenai County, 7.5 mi northeast of Hayden Lake Post Office.

Drainage area: $22.0 \mathrm{mi}^{2}$.

Topography: Steep hills. The general elevation of the divide is about $4,000 \mathrm{ft}$. Basin elevations range from 2,200 to about $5,600 \mathrm{ft}$. The slope of the main stream is about $17 \mathrm{ft} / \mathrm{mi}$.

Rock type: The basin is underlain principally by quartzite and argillite. There are thin alluvial deposits along stream channels. Colluvium covers most of the bedrock.

Vegetation: The basin is covered by second-growth pine and fir.

Manmade influences: Small acreages are logged from time to time. Most are accessed by new road development, with other roads being abandoned. Hydrologic effects are insignificant. Timber in the area has received some pesticide treatment.

Period of record: April 1948 to December 1953, October 1958 to September 1959, October 1965 to September 1980.

Average discharge: $28.3 \mathrm{ft}^{3} / \mathrm{s}$.

Extremes: Maximum discharge, $790 \mathrm{ft}^{3} / \mathrm{s}$, December 23, 1964, gage height, $4.56 \mathrm{ft}$, present site and datum, from rating curve extended above $270 \mathrm{ft}^{3} / \mathrm{s}$ on basis of slope-area measurements; maximum gage height, $4.93 \mathrm{ft}$, February 11, 1951, (ice jam) site and datum then in use; minimum discharge recorded, $1.7 \mathrm{ft}^{3} / \mathrm{s}$, August 19-20, 1977, gage height, $2.25 \mathrm{ft}$; minimum gage height, $2.19 \mathrm{ft}$, December 12, 1972.

Serial correlation coefficient for annual mean discharges: -0.189 .

Kendall's tau correlation coefficient for annual mean discharges: 0.343 .

\begin{tabular}{|c|rrrr|}
\hline \multicolumn{4}{|c|}{ FLOOD FREQUENCY } \\
\hline \multicolumn{4}{|c|}{ Peak discharge, in cubic feet per second, for } \\
indicated recurrence interval, in years \\
\hline $\begin{array}{c}\text { R. I. } \\
\text { Discharge }\end{array}$ & 2 & 5 & 10 & 50 \\
\hline
\end{tabular}

Standard Deviation (logs): 0.309

Skewness Coefficient (logs): -0.501

\begin{tabular}{|c|cccc|}
\hline \multicolumn{4}{|c|}{ LOW-FLOW FREQUENCY } \\
\hline $\begin{array}{c}\text { Consecutive } \\
\text { day period }\end{array}$ & \multicolumn{3}{|c|}{$\begin{array}{l}\text { Discharge, in cubic feet per second for } \\
\text { indicated recurrence interval, in years }\end{array}$} \\
\hline & 2 & 5 & 10 & 50 \\
\cline { 2 - 5 } 7 & 3.4 & 2.7 & 2.4 & 1.9 \\
14 & 3.6 & 2.9 & 2.6 & 2.0 \\
30 & 4.0 & 3.3 & 2.9 & 2.4 \\
60 & 4.3 & 3.5 & 3.2 & 2.6 \\
90 & 4.6 & 3.7 & 3.4 & 2.8 \\
\hline
\end{tabular}

FLOW DURATION

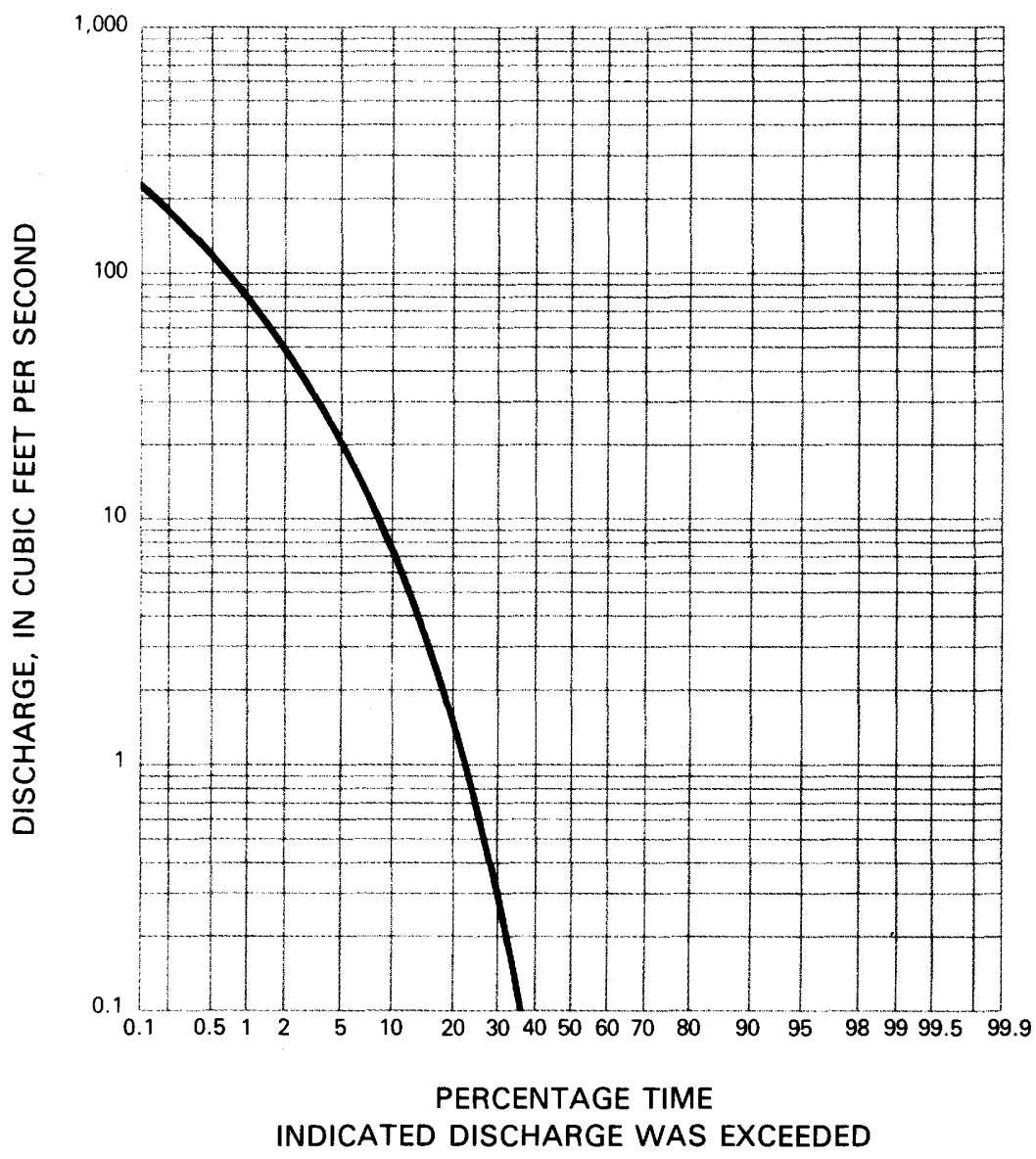



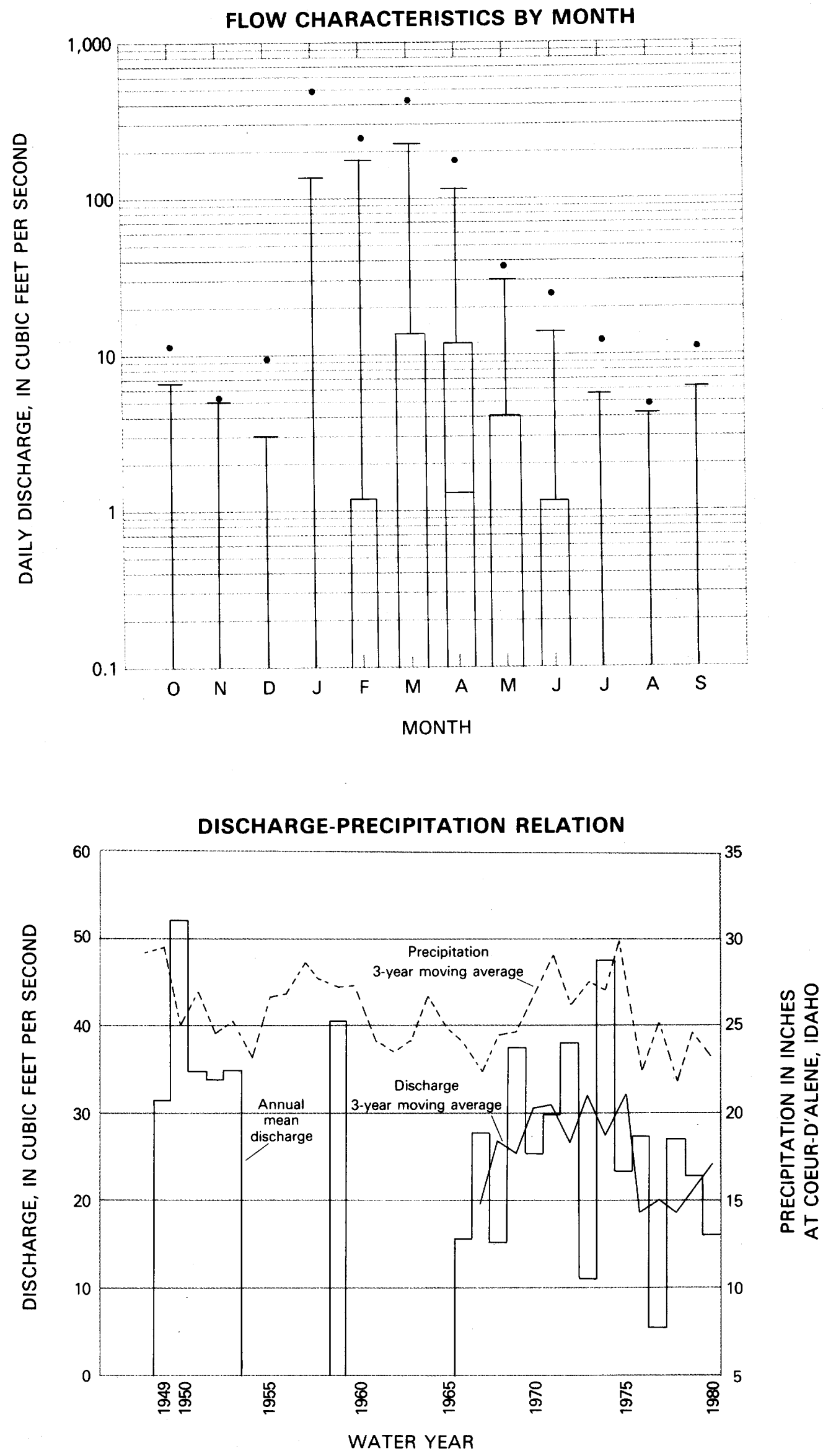
Station 17.-South Hogan Creek near Dillsboro, IN (03276700)

Location: Lat $39^{\circ} 01^{\prime} 47^{\prime \prime}$, long $85^{\circ} 02^{\prime} 17^{\prime \prime}$, Dearborn County, $1.2 \mathrm{mi}$ northeast of Dillsboro.

Drainage area: $38.1 \mathrm{mi}^{2}$.

Topography: Rolling hills having steep-sided valleys. The general elevation of the divide is about $950 \mathrm{ft}$. Basin elevations range from 580 to $995 \mathrm{ft}$. The main stream slope is about $23 \mathrm{ft} / \mathrm{mi}$.

Rock type: Thin till overlying limestone and shale.

Vegetation: Except for small areas of forests near the streams, most of the land is pasture.

Manmade influences: Three small communities having a combined population of about 2,000 (little change in 20 years) lie almost entirely within the basin. Significant housing development along roads has occurred. About 2.5 percent of the basin is in small ponds and lakes.

Period of record: July 1961 to September 1980.

Average discharge: $42.1 \mathrm{ft}^{3} / \mathrm{s}$.

Extremes: Maximum discharge, $13,000 \mathrm{ft}^{3} / \mathrm{s}$, April 29, 1970, gage height, $12.7 \mathrm{ft}$, from floodmarks; no flow at times most years.

Serial correlation coefficient for annual mean discharges: 0.250 .

Kendall's tau correlation coefficient for annual mean discharges: 0.310 .

\begin{tabular}{|c|rrrr|}
\hline \multicolumn{5}{|c|}{ FLOOD FREQUENCY } \\
\hline \multicolumn{4}{|c|}{ Peak discharge, in cubic feet per second, for } \\
indicated recurrence interval, in years \\
\hline $\begin{array}{c}\text { R. I. } \\
\text { Discharge }\end{array}$ & 4 & 5 & 10 & 25 \\
\hline
\end{tabular}

Standard Deviation (logs): 0.250

Skewness Coefficient (logs): 0.226

\begin{tabular}{|c|cccc|}
\hline \multicolumn{5}{|c|}{ LOW-FLOW FREQUENCY } \\
\hline $\begin{array}{c}\text { Consecutive } \\
\text { day period }\end{array}$ & \multicolumn{3}{|c|}{$\begin{array}{c}\text { Discharge, in cubic feet per second for } \\
\text { indicated recurrence interval, in years }\end{array}$} \\
\hline & 2 & 5 & 10 & 20 \\
\cline { 2 - 5 } 7 & 0 & 0 & 0 & 0 \\
14 & .1 & 0 & 0 & 0 \\
30 & .2 & 0 & 0 & 0 \\
60 & .9 & .1 & 0 & 0 \\
90 & 2.4 & .2 & 0 & 0 \\
\hline
\end{tabular}

\section{FLOW DURATION}

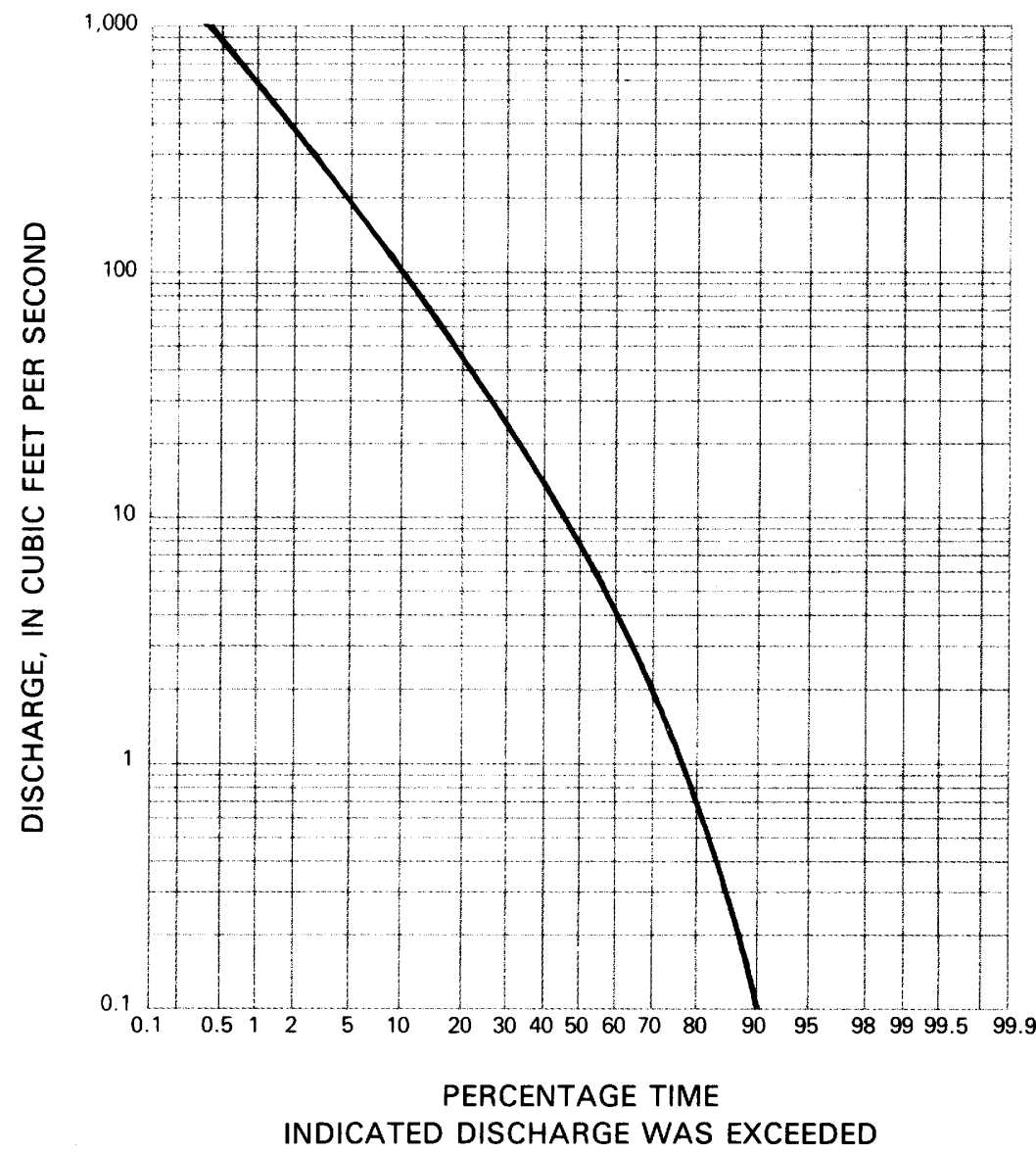



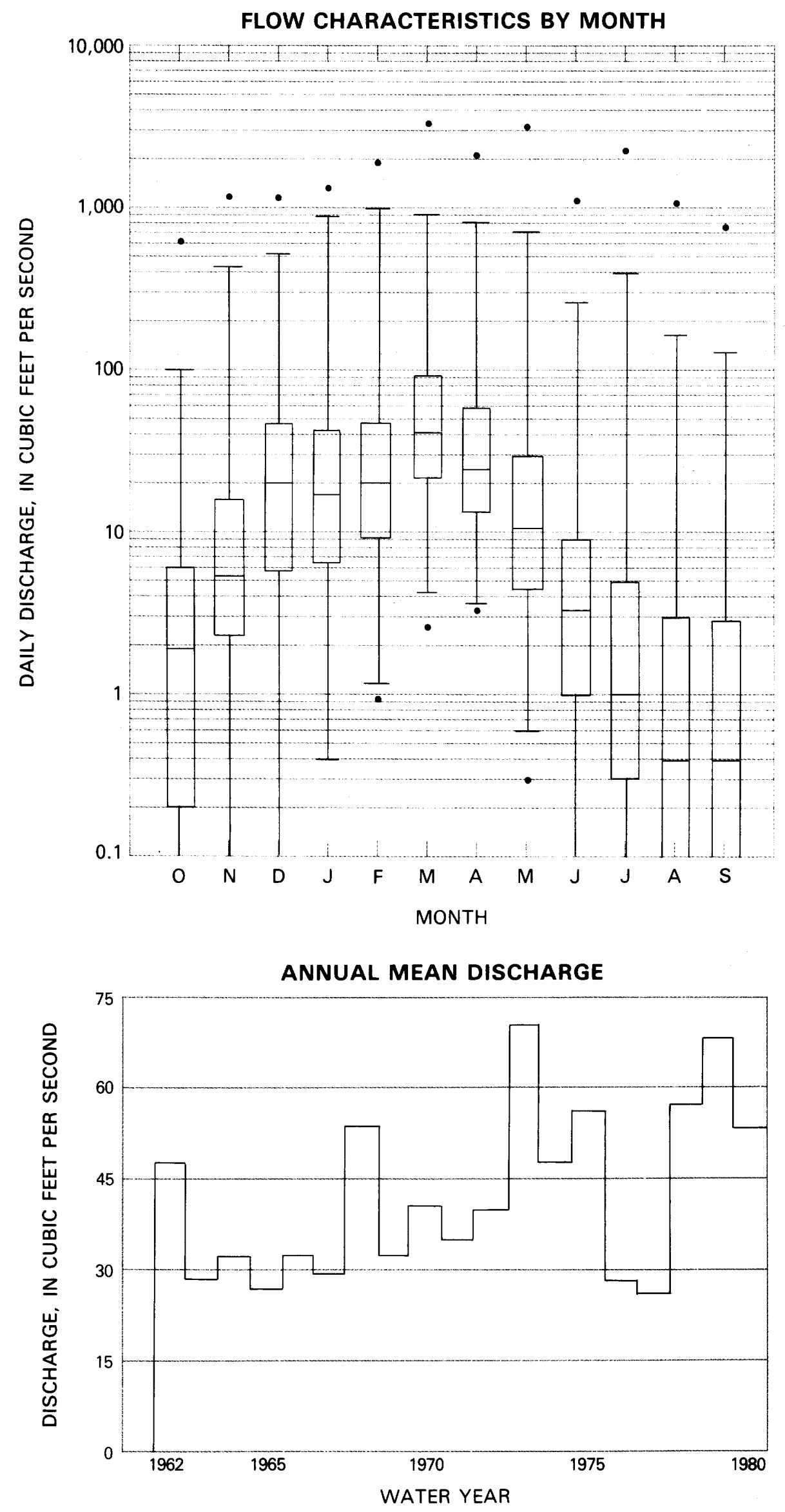
Station 18. -Elk Creek near Decatur City, IA (6897950)

Location: Lat $40^{\circ} 43^{\prime} 18^{\prime \prime}$, long $93^{\circ} 56^{\prime} 12^{\prime \prime}$, Decatur County, 5.7 mi southwest of Decatur City.

Drainage area: $52.5 \mathrm{mi}^{2}$.

Topography: Dissected drift plain. The land surface is fairly rugged and has moderate to steep slopes. Basin elevations range from 250 to $300 \mathrm{ft}$.

Rock type: The basin is underlain by loess-covered glacial drift. Bedrock is predominantly shale intercalated with thin limestone beds.

Vegetation: The upland flats and gentle slopes, which comprise about half the basin, are used for cultivated crops. The steeper areas near the streams are in pasture and timber.

Manmade influences: Two small communities (1980 population, 387) are in the basin. There are numerous stockponds and several roads cross the basin.

Period of record: October 1967 to September 1980.

Average discharge: $30.0 \mathrm{ft}^{3} / \mathrm{s}$.

Extremes: Maximum discharge, $16,400 \mathrm{ft}^{3} / \mathrm{s}$, June 2, 1980, gage height, $28.22 \mathrm{ft}$, from rating curve extended above $5,300 \mathrm{ft}^{3} / \mathrm{s}$ on basis of step-backwater computation; no flow at times most years.

Serial correlation coefficient for annual mean discharges: -0.104 .

Kendall's tau correlation coefficient for annual mean discharges: 0.077 .

\begin{tabular}{|c|rrrr|}
\hline \multicolumn{4}{|c|}{ FLOOD FREQUENCY } \\
\hline \multicolumn{4}{|c|}{$\begin{array}{l}\text { Peak discharge, in cubic feet per second, for } \\
\text { indicated recurrence interval, in years }\end{array}$} \\
\hline $\begin{array}{c}\text { R. I. } \\
\text { Discharge }\end{array}$ & 2 & 5 & 10 & 25 \\
\hline
\end{tabular}

Standard Deviation (logs): 0.511

Skewness Coefficient (logs): -0.624

\begin{tabular}{|c|c|c|c|c|}
\hline \multicolumn{5}{|c|}{ LOW-FLOW FREQUENCY } \\
\hline $\begin{array}{l}\text { Consecutive } \\
\text { day period }\end{array}$ & \multicolumn{4}{|c|}{$\begin{array}{l}\text { Discharge, in cubic feet per second for } \\
\text { indicated recurrence interval, in years }\end{array}$} \\
\hline & 2 & 5 & 10 & 20 \\
\hline $\begin{array}{r}7 \\
14 \\
30 \\
60 \\
90\end{array}$ & \multicolumn{4}{|c|}{$\begin{array}{l}\text { Long periods of no } \\
\text { flow for most years. }\end{array}$} \\
\hline
\end{tabular}

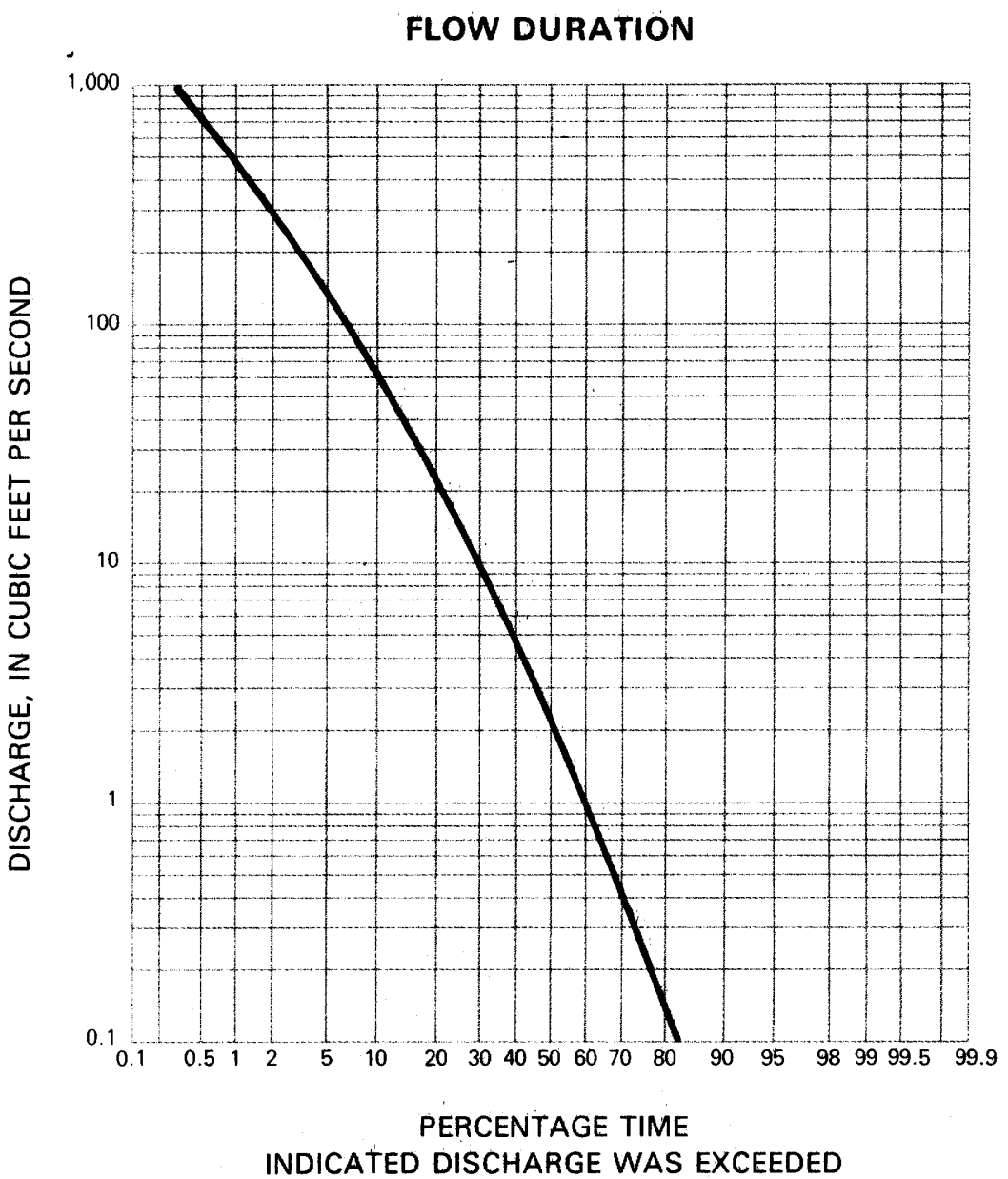



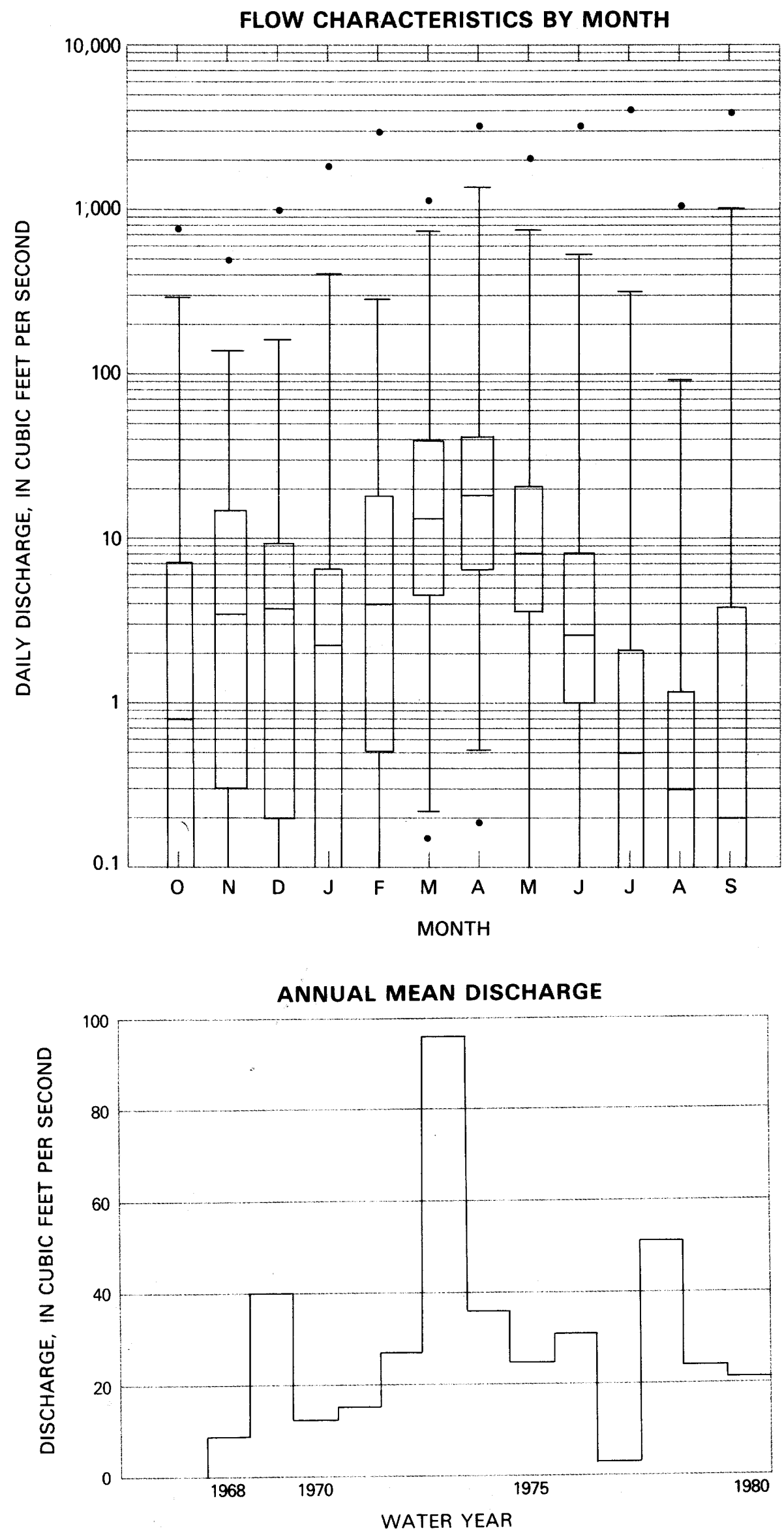

Station 19. - Kings Creek near Manhattan, KS (06879650)

Location: Lat $39^{\circ} 06^{\prime} 07^{\prime \prime}$, long $96^{\circ} 35^{\prime} 42^{\prime \prime}$, Riley County, 2.9 mi upstream from mouth, 6.0 mi south of Manhattan.

Drainage area: $4.09 \mathrm{mi}^{2}$.

Topography: Dissected upland, rolling to hilly. Narrow floodplain along main stream and two main tributaries. Basin elevations range from 1,110 to $1,450 \mathrm{ft}$. The slope of the main stream is about $90 \mathrm{ft} / \mathrm{mi}$.

Rock type: Rocks at and near the surface are predominantly cherty limestone and shale.

Vegetation: The basin has been in the process of reverting to native tallgrass (bluestem) prairie since 1978 when cattle grazing was stopped. In most of the basin, intrusion of brushwood is prevented by controlled burning. Some broadleaf trees, junipers, and brushwood are in the valleys.

Manmade influences: The basin is entirely within Kansas State University's ecological research area where manmade influences are minimal.

Period of record: April 1979 to September 1980.

Extremes: Maximum discharge, $242 \mathrm{ft} / 3 / \mathrm{s}$, March 29, 1980, gage height, $5.64 \mathrm{ft}$, from rating curve extended above 50 $\mathrm{ft}^{3} / \mathrm{s}$ on basis of step-backwater analysis; no flow for many days.

NOTE: The record is too short to present streamflow characteristics. 
Station 20. - Big Creek at Pollock, LA (07373000)

Location: Lat $31^{\circ} 32^{\prime} 10^{\prime \prime}$, long $92^{\circ} 24^{\prime} 30^{\prime \prime}$, Grant Parish, 0.8 mi north of Pollock.

Drainage area: $51 \mathrm{mi}^{2}$.

Topography: Rolling hills. Basin elevations range from 78 to $289 \mathrm{ft}$. The slope of the main stream is about $11 \mathrm{ft} / \mathrm{mi}$.

Rock type: Surficial deposits of unconsolidated sand and gravel 75 to $100 \mathrm{ft}$ thick overlay sand and clay.

Vegetation: Except for a few square miles of open land, the basin is covered with second-growth pine.

Manmade influences: The community of Dry Prong (1980 population, 430) is in the upper part of the basin. It has no public water system. A sewer system was installed in 1980. There are several roads traversing the basin and a few gravel pits and stockponds. Most of the basin is in the Kisatchie National Forest where controlled logging is practiced.

Period of record: January 1942 to September 1980.

Average discharge: $61.0 \mathrm{ft}^{3} / \mathrm{s}$.

Extremes: Maximum discharge, 23,500 ft $3 / \mathrm{s}$, April 29, 1953, gage height, $18.03 \mathrm{ft}$ ( $16.90 \mathrm{ft}$ at site then in use); minimum, $3.7 \mathrm{ft}^{3} / \mathrm{s}$, September 29, 1956; gage height, $1.08 \mathrm{ft}$.

Serial correlation coefficient for annual mean discharges: 0.150 .

Kendall's tau correlation coefficient for annual mean discharges: 0.021 .

\section{FLOW DURATION}

\begin{tabular}{|c|rrrrr|}
\hline \multicolumn{7}{|c|}{ FLOOD FREQUENCY } \\
\hline \multicolumn{5}{|c|}{$\begin{array}{c}\text { Peak discharge, in cubic feet per second, for } \\
\text { indicated recurrence interval, in years }\end{array}$} \\
\hline $\begin{array}{c}\text { R. I. } \\
\text { Discharge }\end{array}$ & 2 & 5 & 10 & 50 & 100 \\
\hline
\end{tabular}

Standard Deviation (logs): 0.500

Skewness Coefficient (logs): 0.035

\begin{tabular}{|c|rrrrr|}
\hline \multicolumn{5}{|c|}{ LOW-FLOW FREQUENCY } \\
\hline $\begin{array}{r}\text { Consecutive } \\
\text { day period }\end{array}$ & \multicolumn{4}{|c|}{$\begin{array}{l}\text { Discharge, in cubic feet per second for } \\
\text { indicated recurrence interval, in years }\end{array}$} \\
\hline & \multicolumn{1}{|c}{2} & 5 & 10 & 50 & 100 \\
\cline { 2 - 6 } 7 & 12.7 & 9.0 & 7.4 & 5.0 & 4.3 \\
14 & 13.4 & 9.5 & 7.9 & 5.5 & 4.8 \\
30 & 14.8 & 10.7 & 8.9 & 6.5 & 5.8 \\
60 & 16.6 & 12.0 & 10.1 & 7.4 & 6.7 \\
90 & 18.0 & 12.7 & 10.7 & 8.0 & 7.3 \\
\hline
\end{tabular}

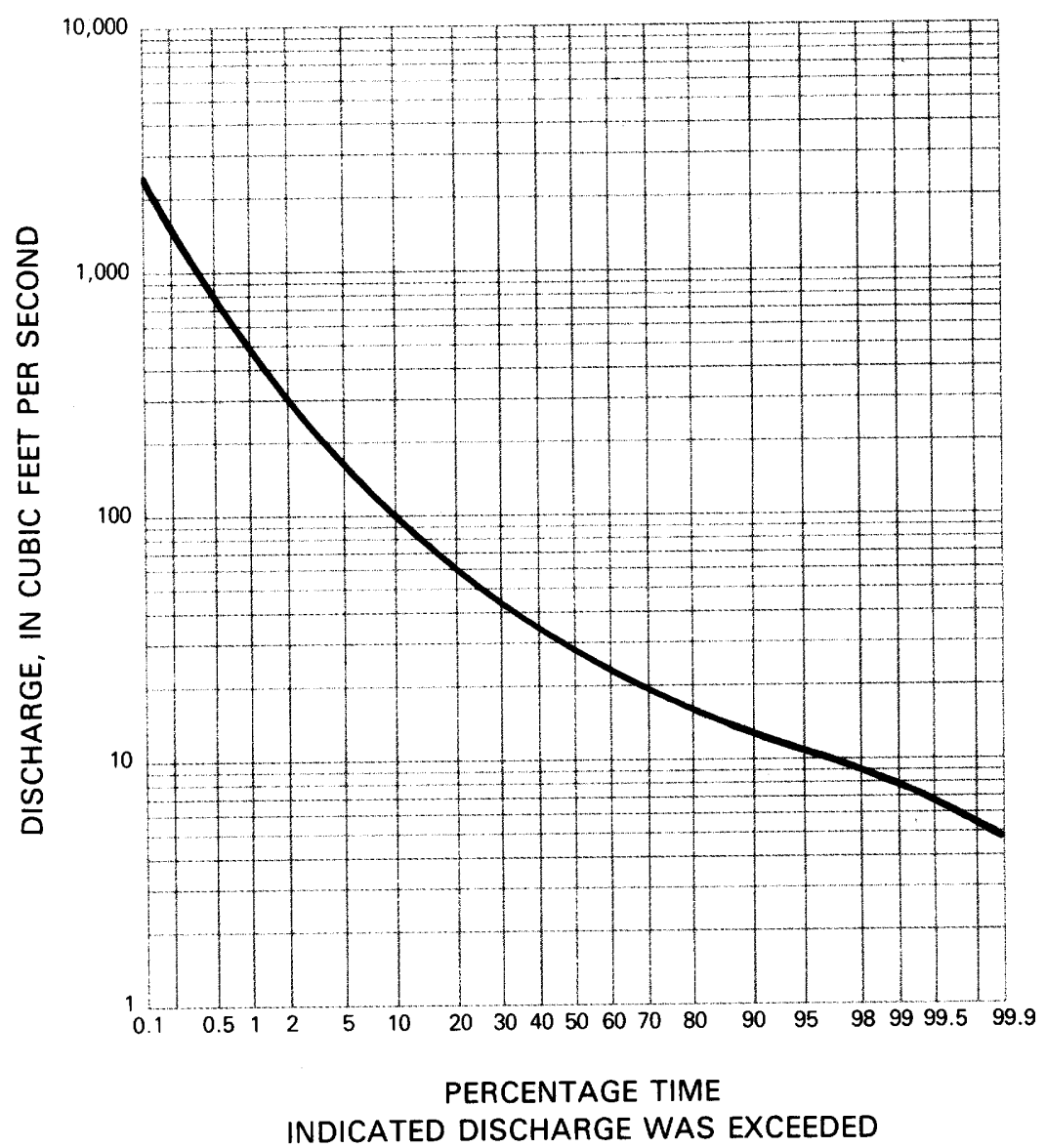



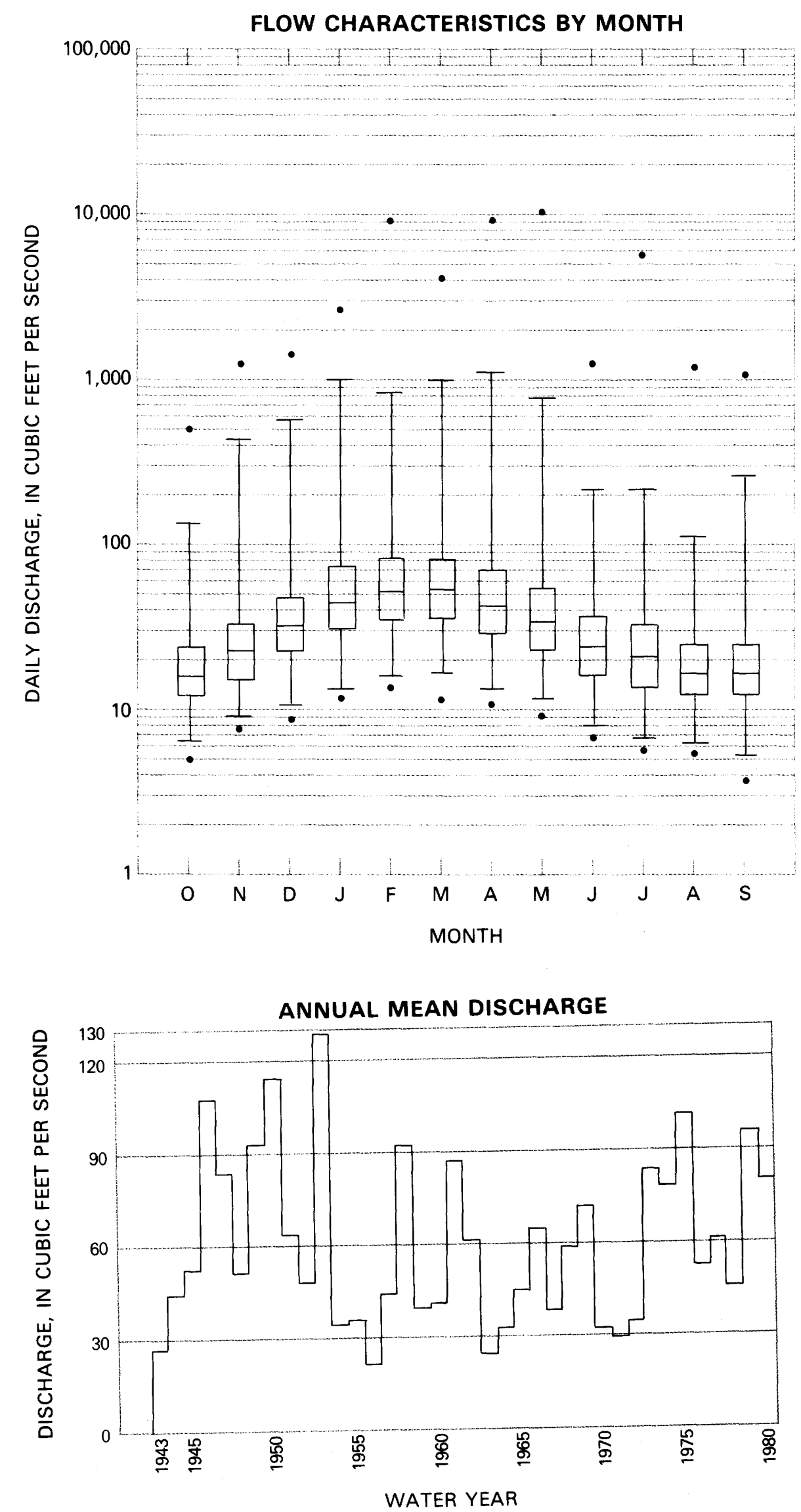
Station 21. - Wild River at Gilead, ME (01054200)

Location: Lat $44^{\circ} 23^{\prime} 26^{\prime \prime}$, long $70^{\circ} 58^{\prime} 46^{\prime \prime}$, Oxford County, 0.4 mi west of Gilead.

Drainage area: $69.5 \mathrm{mi}^{2}$.

Topography: The basin is deeply dissected. Landslopes are steep. Basin elevations range from 700 to $4,800 \mathrm{ft}$.

Rock type: The basin is underlain by gneiss and schist. Glacial till occurs on slopes and at higher elevations.

Vegetation: Hardwood forests cover the basin except for some small groves of coniferous trees.

Manmade influences: About 98 percent of the basin is in the White Mountain National Forest. Logging activity takes place on relatively small acreages most years.

Period of record: July 1964 to September 1980.

Average discharge: $179 \mathrm{ft}^{3} / \mathrm{s}$.

Extremes: Maximum discharge, $12,500 \mathrm{ft}^{3} / \mathrm{s}$, November 3, 1966, gage height, $12.49 \mathrm{ft}$; minimum, $7.6 \mathrm{ft}^{3} / \mathrm{s}$, July 16 , 1971; gage height, $1.89 \mathrm{ft}$.

Serial correlation coefficient for annual mean discharges: 0.360 .

Kendall's tau correlation coefficient for annual mean discharges: 0.283.

\begin{tabular}{|c|rrrr|}
\hline \multicolumn{5}{|c|}{ FLOOD FREQUENCY } \\
\hline \multicolumn{4}{|c|}{$\begin{array}{l}\text { Peak discharge, in cubic feet per second, for } \\
\text { indicated recurrence interval, in years }\end{array}$} \\
\hline $\begin{array}{c}\text { R. I. } \\
\text { Discharge }\end{array}$ & 2 & 5 & 10 & 25 \\
\hline
\end{tabular}

Standard Deviation (logs): 0.276

Skewness Coefficient (logs): -0.218

\begin{tabular}{|c|cccc|}
\hline \multicolumn{5}{|c|}{ LOW-FLOW FREQUENCY } \\
\hline $\begin{array}{c}\text { Consecutive } \\
\text { day period }\end{array}$ & \multicolumn{3}{|c|}{$\begin{array}{l}\text { Discharge, in cubic feet per second for } \\
\text { indicated recurrence interval, in years }\end{array}$} \\
\hline & 2 & 5 & 10 & 20 \\
\cline { 2 - 5 } 7 & 14.2 & 10.7 & 9.4 & 8.5 \\
14 & 16.0 & 11.8 & 10.2 & 9.2 \\
30 & 21.3 & 16.0 & 13.8 & 12 \\
60 & 27.7 & 20.7 & 17.6 & 15 \\
90 & 36.8 & 26.7 & 22.3 & 19 \\
\hline
\end{tabular}

\section{FLOW DURATION}

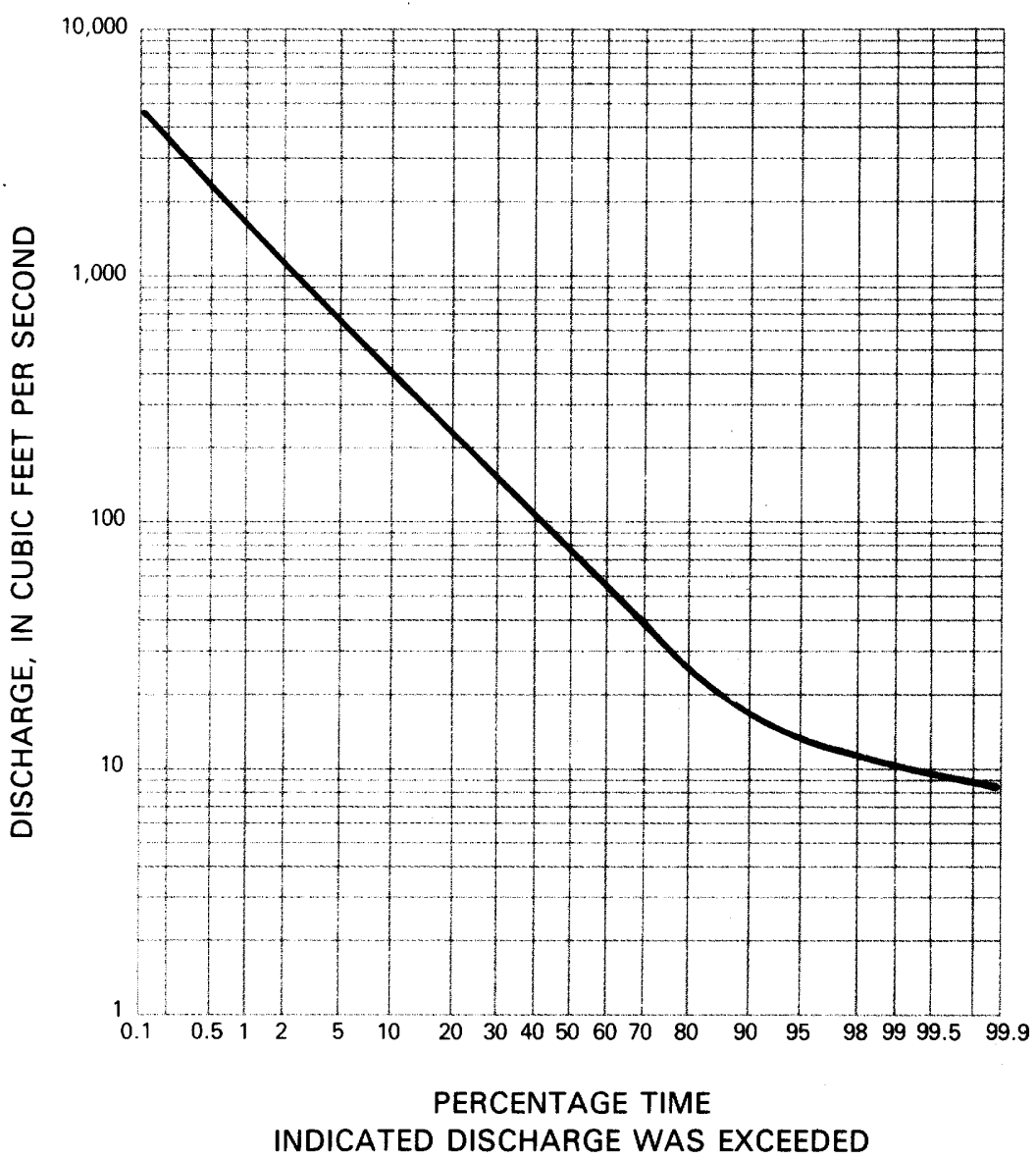



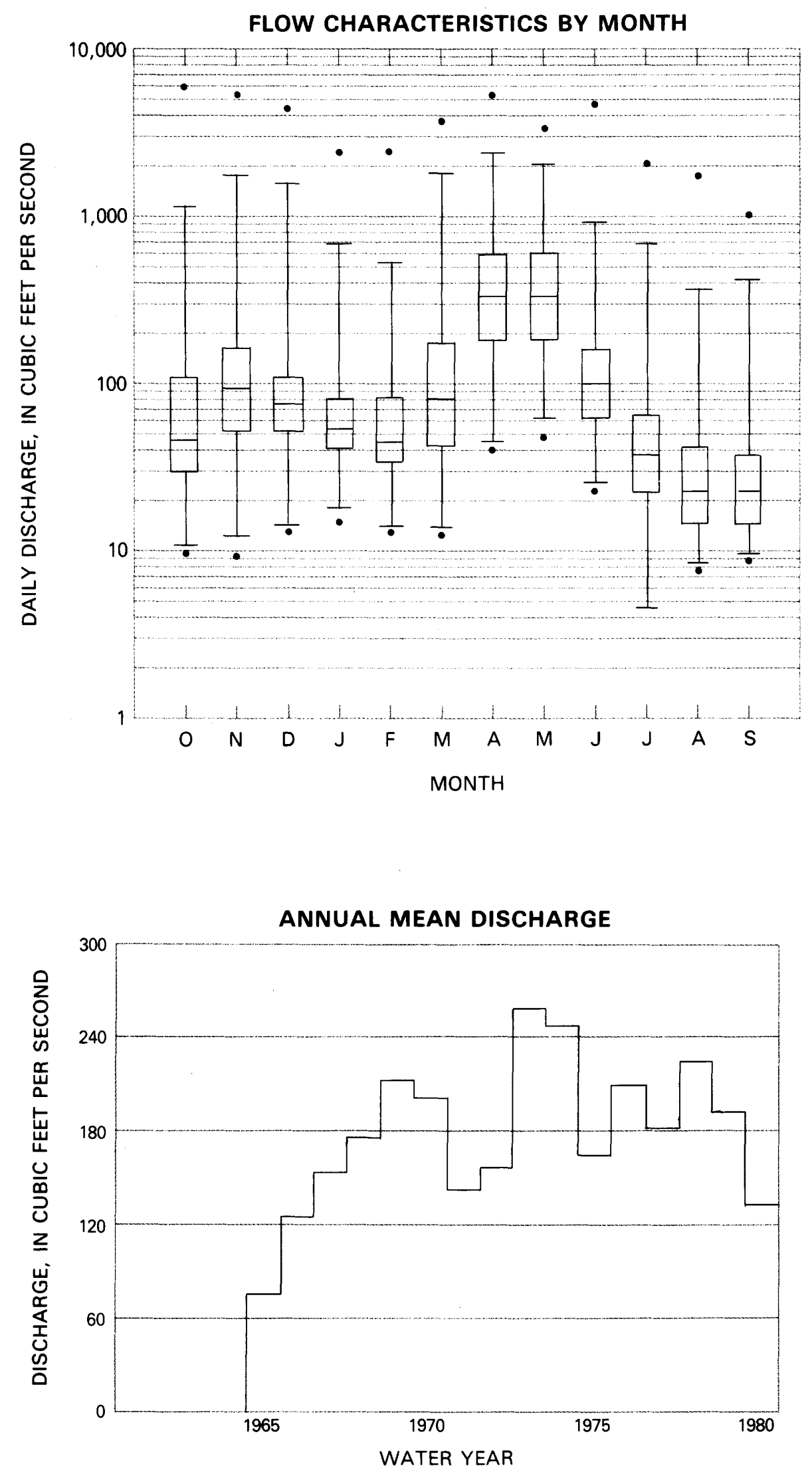
Location: Lat $47^{\circ} 55^{\prime} 23^{\prime \prime}$, long $89^{\circ} 08^{\prime} 42^{\prime \prime}$, Keweenaw County, 0.8 mi northeast of Windigo, Isle Royal National Park.

Drainage area: $13.2 \mathrm{mi}^{2}$.

Topography: Pronounced northeast-southwest trending valleys and ridges. The highlands are rugged and the lowland areas are swampy. Basin elevations range from 600 to $1,394 \mathrm{ft}$. The slope of the main stream is about $43 \mathrm{ft} / \mathrm{mi}$.

Rock type: Old lava flows with thin interbedded river-deposited sandstone and conglomerate layers underlie the basin. Stream valleys have some glacial deposits with a maximum known thickness of $60 \mathrm{ft}$.

Vegetation: The interior upland part of the basin is forested primarily with sugar maple and yellow birch. The lowland areas are forested primarily with white spruce and balsam fir. Small natural clearings exist on the basaltic outcrops on the ridges.

Manmade influences: The basin is entirely within and at the western end of Isle Royale National Park. Some copper mining took place on the island before 1900. Forest fires have swept parts of the island during the first half of this century.

Period of record: October 1964 to September 1980.

Average discharge: $17.7 \mathrm{ft}^{3} / \mathrm{s}$.

Extremes: Maximum discharge, $480 \mathrm{ft}^{3} / \mathrm{s}$, May 1, 1972, gage height, $6.82 \mathrm{ft}$, from rating curve extended above 160 $\mathrm{ft}^{3} / \mathrm{s}$ based on runoff characteristics of nearby stations, maximum gage height, $6.88 \mathrm{ft}$, January 13, 1975, backwater from ice; minimum daily discharge, $0.44 \mathrm{ft}^{3} / \mathrm{s}$, August 25, 1977, minimum gage height, $2.55 \mathrm{ft}$, August 29, 30, 31, September $2,3,7,9,10,11,12,1976$.

Serial correlation coefficient for annual mean discharges: 0.274 .

Kendall's tau correlation coefficient for annual mean discharges: -0.533 .

\begin{tabular}{|c|rrrr|}
\hline \multicolumn{5}{|c|}{ FLOOD FREQUENCY } \\
\hline \multicolumn{4}{|c|}{ Peak discharge, in cubic feet per second, for } \\
indicated recurrence interval, in years \\
\hline $\begin{array}{c}\text { R. I. } \\
\text { Discharge }\end{array}$ & 2 & 5 & 10 & 25 \\
\hline
\end{tabular}

Standard Deviation (logs): 0.188

Skewness Coefficient (logs): -0.470

\begin{tabular}{|c|cccc|}
\hline \multicolumn{5}{|c|}{ LOW-FLOW FREQUENCY } \\
\hline $\begin{array}{l}\text { Consecutive } \\
\text { day period }\end{array}$ & \multicolumn{3}{|c|}{$\begin{array}{l}\text { Discharge, in cubic feet per second for } \\
\text { indicated recurrence interval, in years }\end{array}$} \\
\hline & 2 & 5 & 10 & 20 \\
\hline 7 & 1.2 & 0.7 & 0.6 & 0.5 \\
14 & 1.3 & 0.8 & 0.6 & 0.6 \\
30 & 1.5 & 0.9 & 0.8 & 0.7 \\
60 & 2.0 & 1.2 & 0.9 & 0.8 \\
90 & 2.7 & 1.5 & 1.1 & 0.8 \\
\hline
\end{tabular}

\section{FLOW DURATION}

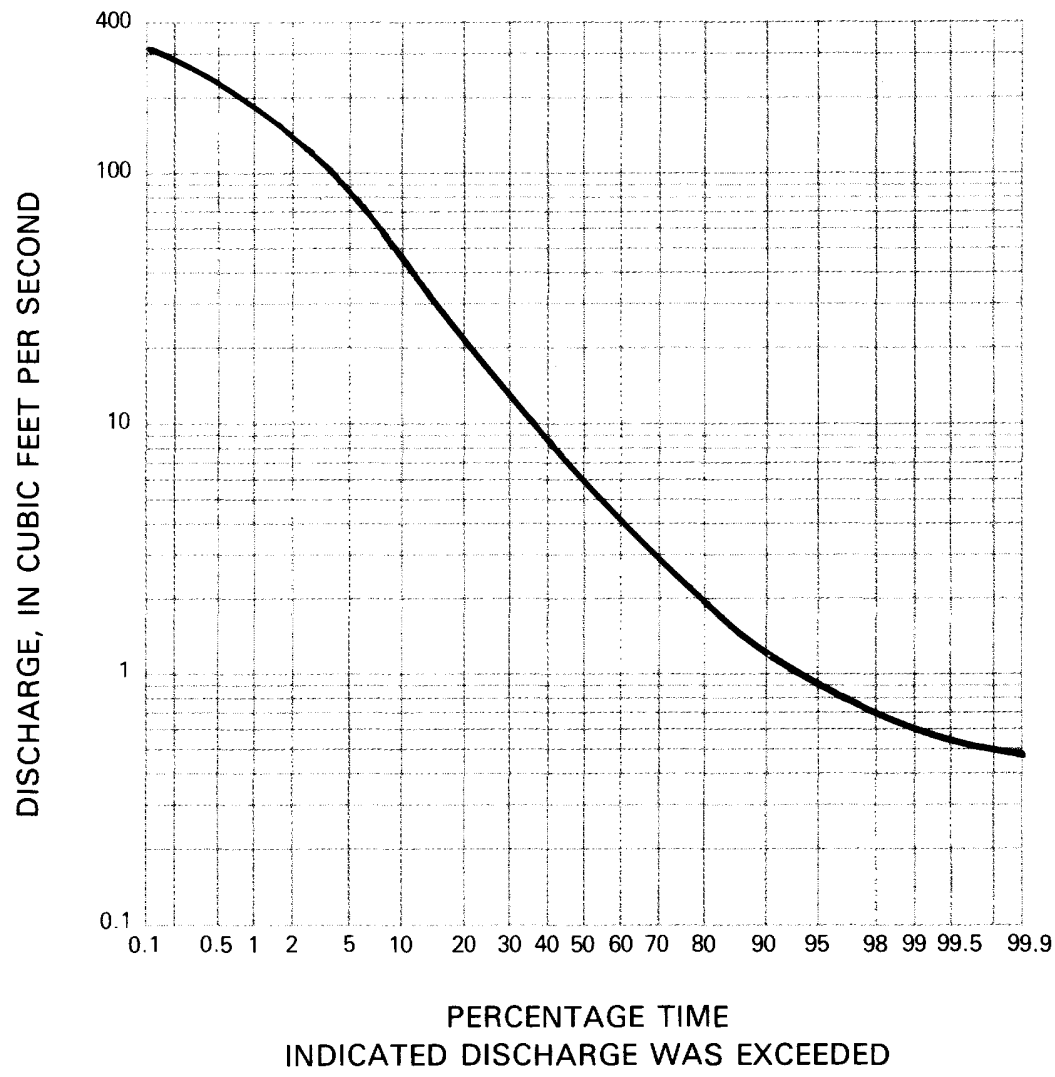



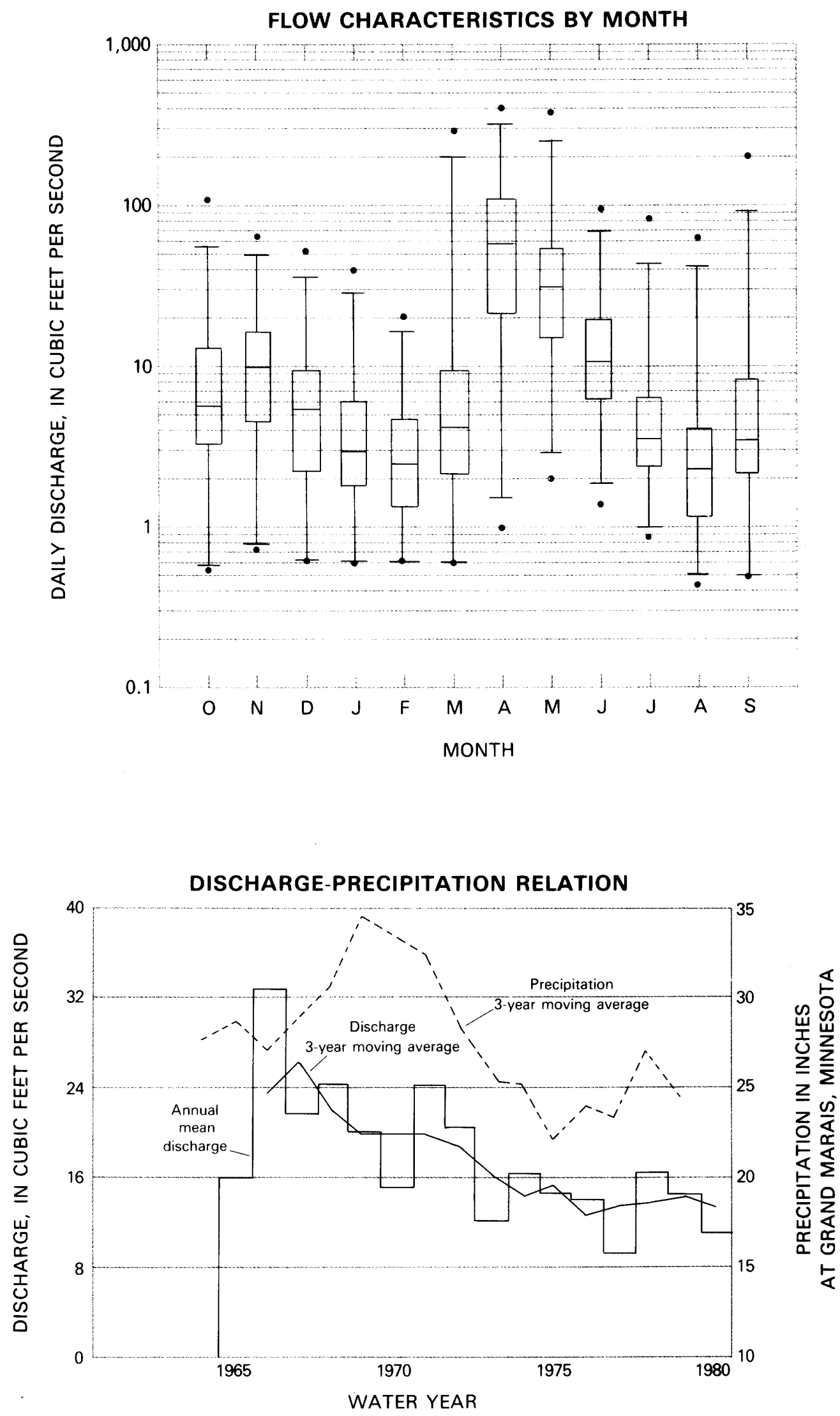
Station 23. - Kawishiwi River near Ely, MN (05124480)

Location: Lat $47^{\circ} 55^{\prime} 22^{\prime \prime}$, long $91^{\circ} 32^{\prime} 06^{\prime \prime}$, Lake County, 14 mi east of Ely.

Drainage area: $253 \mathrm{mi}^{2}$.

Topography: The general surface of the land is rolling. The Kawishiwi River passes through many lakes and swamps. The average divide elevation is about $1,800 \mathrm{ft}$. Basin elevations range from 1,450 to $2,110 \mathrm{ft}$. The main stream drops from an elevation of 1,640 to $1,450 \mathrm{ft}$ in a distance of about $40 \mathrm{mi}$.

Rock type: The basin is part of the Canadian Shield. The rocks are crystalline and consist mostly of gabbro, granite, and greenstone.

Vegetation: The basin is covered by Great Lakes pine forest.

Manmade influences: The basin is almost entirely in the Boundary Waters Canoe Area of the Superior National Forest. There are few roads in the basin. Camping, fishing, and boating are man's primary influence on the area, which has been logged in past years near the edge of the basin; however, present logging operations consist of selective cutting of mature trees only.

Period of record: June 1966 to September 1980.

Average discharge: $217 \mathrm{ft}^{3} / \mathrm{s}$.

Extremes: Maximum discharge, 1,720 ft ${ }^{3} / \mathrm{s}$, April 24, 1976, gage height, $5.92 \mathrm{ft}$; minimum, $4.5 \mathrm{ft}^{3} / \mathrm{s}$, January 30 to February 2, 1977, gage height, $2.14 \mathrm{ft}$.

Serial correlation coefficient for annual mean discharges: 0.168 .

Kendall's tau correlation coefficient for annual mean discharges: -0.275 .

\section{FLOW DURATION}

\begin{tabular}{|r|rrrr|}
\hline \multicolumn{5}{|c|}{ FLOOD FREQUENCY } \\
\hline \multicolumn{4}{|c|}{$\begin{array}{c}\text { Peak discharge, in cubic feet per second, for } \\
\text { indicated recurrence interval, in years }\end{array}$} \\
\hline R. I. & 2 & 5 & 10 & 25 \\
Discharge & 1,150 & 1,450 & 1,630 & 1,840 \\
\hline
\end{tabular}

Standard Deviation (logs): 0.124

Skewness Coefficient (logs): -0.182

\begin{tabular}{|c|cccc|}
\hline \multicolumn{5}{|c|}{ LOW-FLOW FREQUENCY } \\
\hline $\begin{array}{c}\text { Consecutive } \\
\text { day period }\end{array}$ & \multicolumn{3}{|c|}{$\begin{array}{c}\text { Discharge, in cubic feet per second for } \\
\text { indicated recurrence interval, in years }\end{array}$} \\
\hline & 2 & 5 & 10 & 20 \\
\cline { 2 - 5 } 7 & 38 & 18 & 11 & 6.3 \\
14 & 39 & 18 & 11 & 6.4 \\
30 & 42 & 20 & 11 & 6.8 \\
60 & 47 & 21 & 13 & 7.5 \\
90 & 62 & 30 & 17 & 10 \\
\hline
\end{tabular}

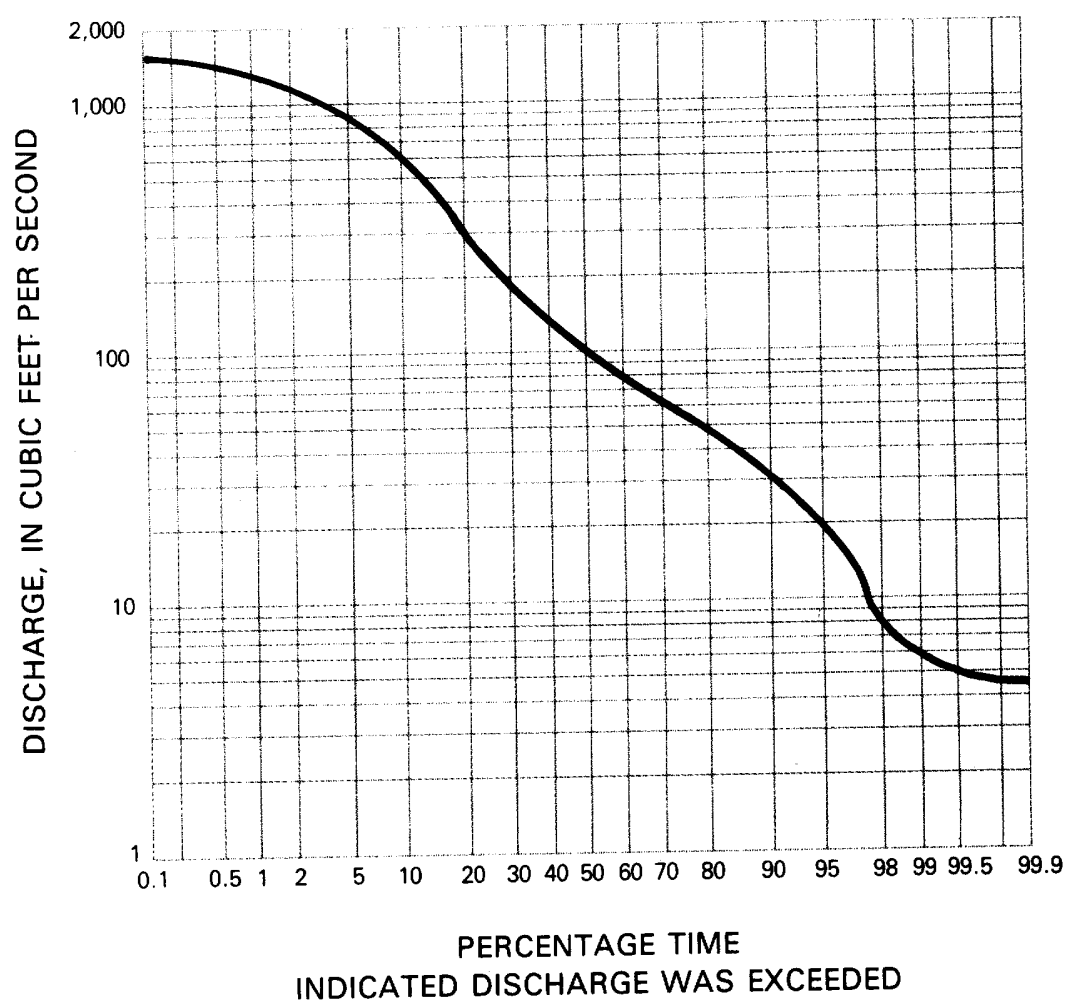



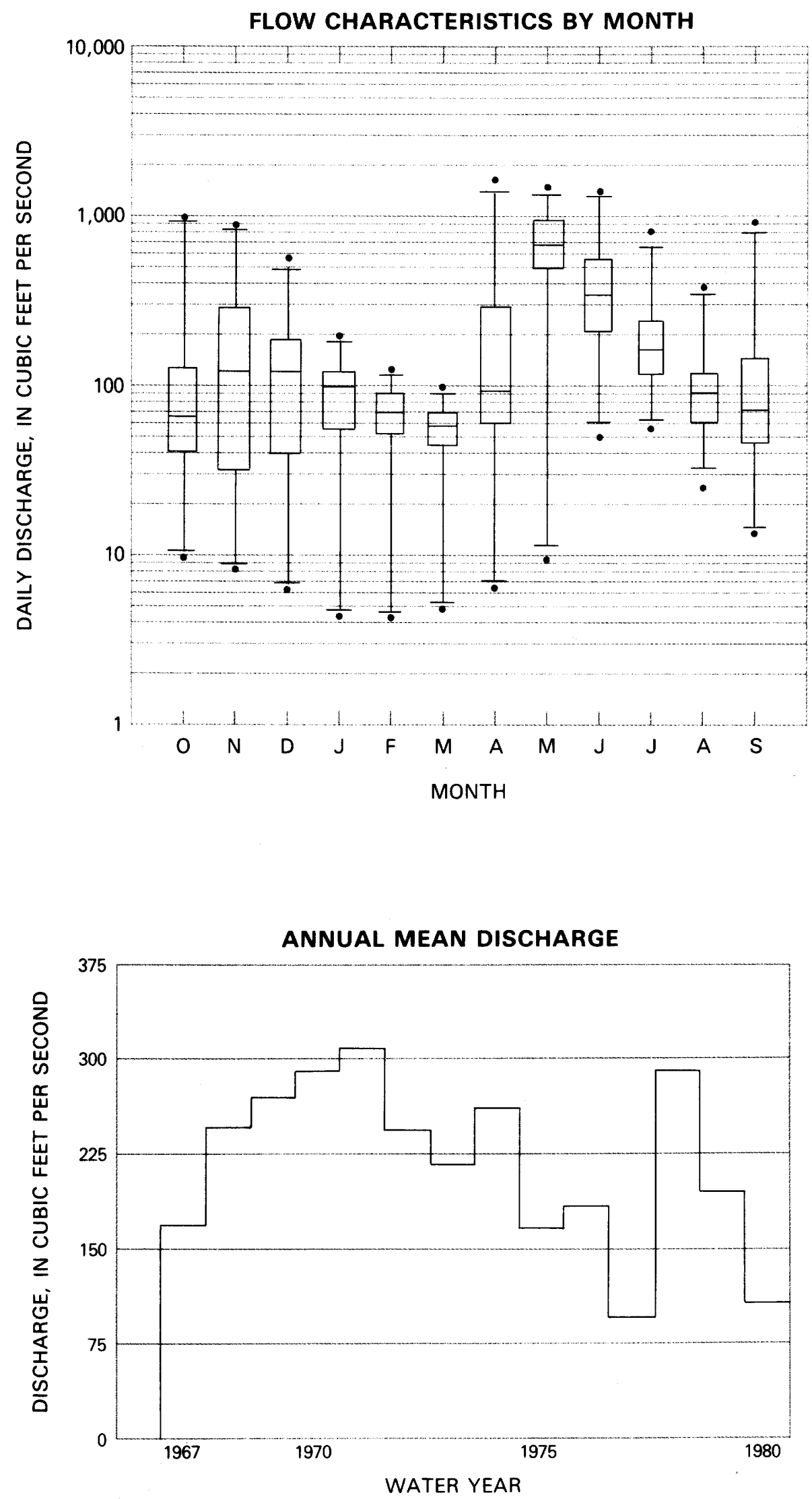
Station 24. - North Fork Whitewater River near Elba, MN (05376000)

Location: Lat $44^{\circ} 05^{\prime} 30^{\prime \prime}$, long $92^{\circ} 03^{\prime} 57^{\prime \prime}$, Winona County, 2.4 mi west of Elba.

Drainage area: $101 \mathrm{mi}^{2}$.

Topography: The land surface in the upper 80 percent of the basin is gently rolling farmland. The lower 20 percent of the basin is characterized by high steep bluffs. The average elevation of the divide is about $1,100 \mathrm{ft}$. Basin elevations range from 770 to $1,300 \mathrm{ft}$. The slope of the main stream is about $15 \mathrm{ft} / \mathrm{mi}$.

Rock type: Sedimentary formations consisting largely of sandstone and dolomite.

Vegetation: The upper 80 percent is agricultural, and the lower 20 percent is generally maple-basswood forests.

Manmade influences: Three small communities are located wholly or partly within the upper part of the basin. Total population in the basin is less than 2,500. There are several roads crossing the basin. Man's major influence is due to agricultural use of the land. Part of the basin is in the Minnesota Memorial Hardwood State Forest.

Period of record: May 1939 to September 1941, July 1967 to September 1980.

Average discharge: $45.2 \mathrm{ft}^{3} / \mathrm{s}$.

Extremes: Maximum discharge, 16,100 ft $\mathrm{ft}^{3} / \mathrm{s}$, June 21, 1974, gage height, $16.32 \mathrm{ft}$ from floodmark; minimum, $11 \mathrm{ft}^{3} / \mathrm{s}$, February 21, 1968.

Serial correlation coefficient for annual mean discharges: 0.487 .

Kendall's tau correlation coefficient for annual mean discharges: 0.359 .

\begin{tabular}{|c|rrrr|}
\hline \multicolumn{5}{|c|}{ FLOOD FREQUENCY } \\
\hline \multicolumn{4}{|c|}{ Peak discharge, in cubic feet per second, for } \\
indicated recurrence interval, in years \\
\hline R. I. & 2 & 5 & 10 & 25 \\
Discharge & 2,540 & 6,100 & 9,550 & 15,300 \\
\hline
\end{tabular}

Standard Deviation (logs): 0.460

Skewness Coefficient (logs): -0.109

\begin{tabular}{|c|cccc|}
\hline \multicolumn{4}{|c|}{ LOW-FLOW FREQUENCY } \\
\hline $\begin{array}{l}\text { Consecutive } \\
\text { day period }\end{array}$ & \multicolumn{3}{|c|}{$\begin{array}{l}\text { Discharge, in cubic feet per second for } \\
\text { indicated recurrence interval, in years }\end{array}$} \\
\hline & 2 & 5 & 10 & 20 \\
\cline { 2 - 5 } 7 & 22 & 17 & 15 & 14 \\
14 & 22 & 18 & 16 & 15 \\
30 & 23 & 19 & 17 & 15 \\
60 & 25 & 19 & 17 & 15 \\
90 & 26 & 20 & 17 & 15 \\
\hline
\end{tabular}

FLOW DURATION

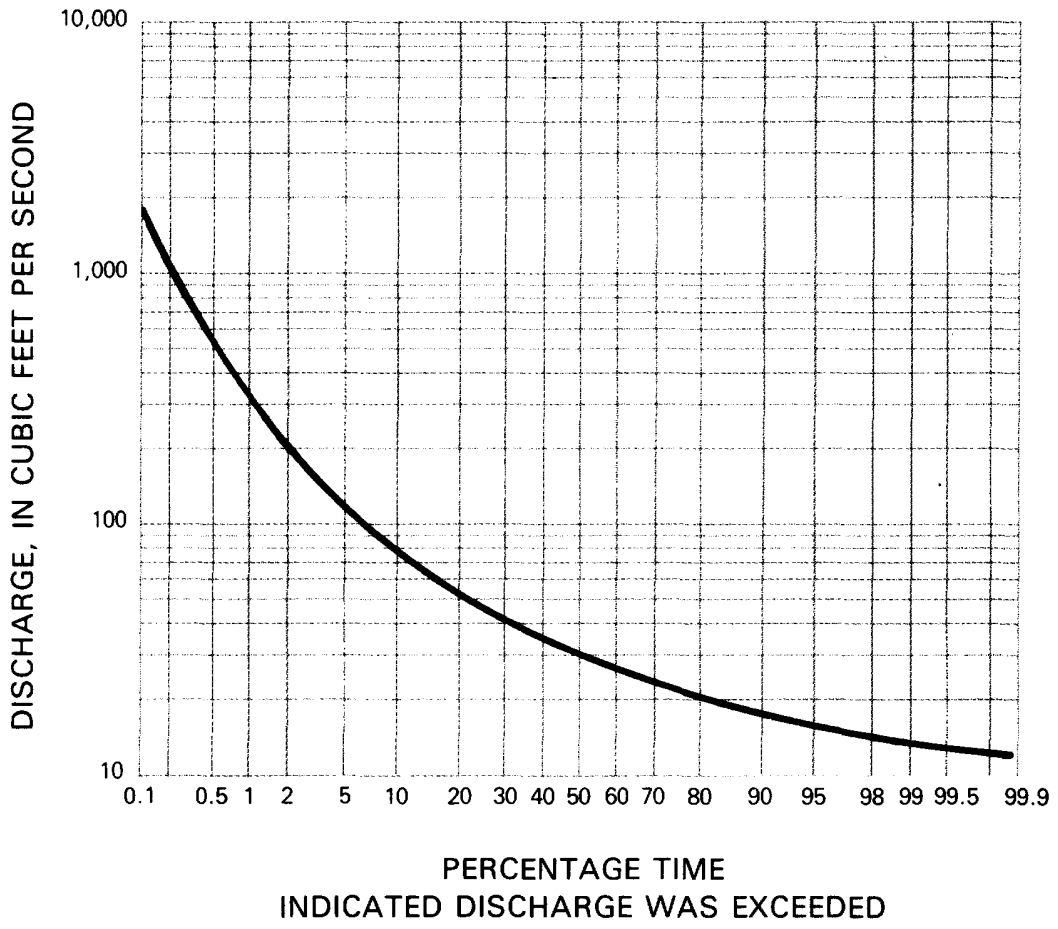


55

FLOW CHARACTERISTICS BY MONTH

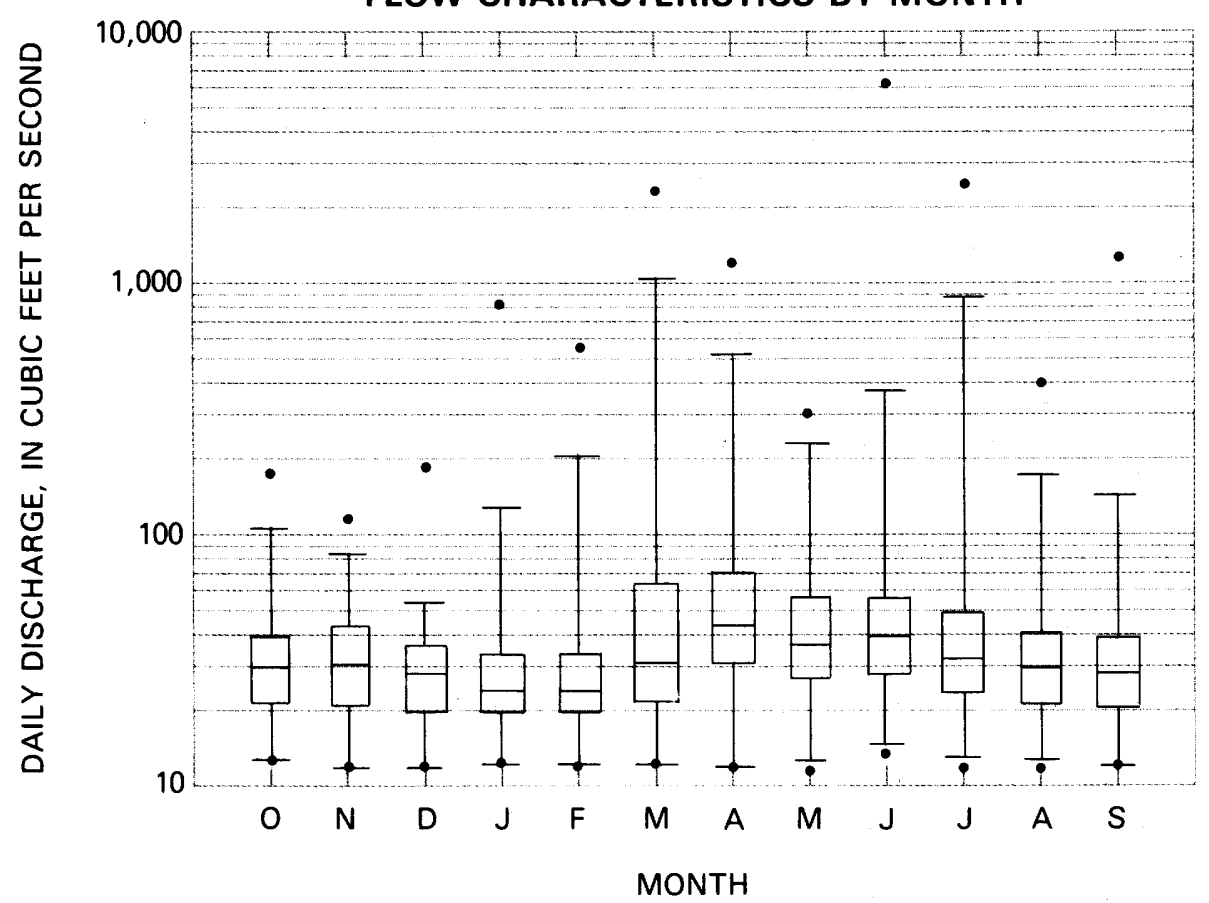

ANNUAL MEAN DISCHARGE

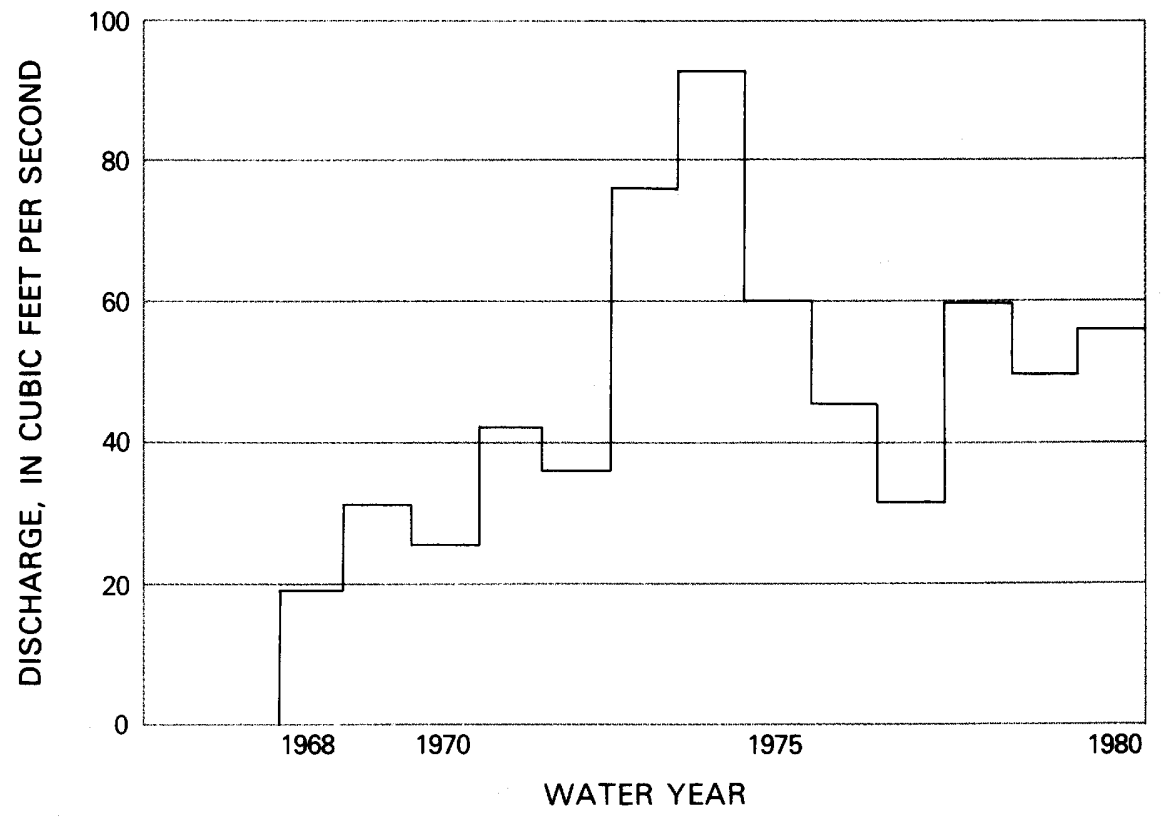


Station 25. - Cypress Creek near Janice, MS (02479155)

Location: Lat $31^{\circ} 01^{\prime} 30^{\prime \prime}$, long $89^{\circ} 01^{\prime} 00^{\prime \prime}$, Perry County, 1.2 mi east of Janice.

Drainage area: $52.6 \mathrm{mi}^{2}$.

Topography: The land surface is generally rolling and has half-mile wide floodplains along the main stream. Swamps cover about $2 \mathrm{mi}^{2}$ in the upper part of the basin. Basin elevations range from 110 to $330 \mathrm{ft}$.

Rock type: Sand-and-gravel deposits form the ridges and sand and clay underlie the remainder of the basin.

Vegetation: Most of the basin is covered with second-growth pine. A few acres along the divide are cultivated and there are some deciduous trees along the streams.

Manmade influences: The basin is in DeSoto National Forest. The upper one-half is a "special use area" for the Mississippi National Guard. Logging is practiced on a sustained-yield basis. A few families occupy land along the drainage divide.

Period of record: October 1966 to September 1980.

Average discharge: $103 \mathrm{ft}^{3} / \mathrm{s}$.

Extremes: Maximum discharge, 12,500 ft³/s, April 4, 1979, gage height, $28.67 \mathrm{ft}$; minimum, $4.5 \mathrm{ft}^{3} / \mathrm{s}$, September 2, 3, 1968.

Serial correlation coefficient for annual mean discharges: 0.653 .

Kendall's tau correlation coefficient for annual mean discharges: 0.648 .

\begin{tabular}{|c|rrrr|}
\hline \multicolumn{5}{|c|}{ FLOOD FREQUENCY } \\
\hline \multicolumn{4}{|c|}{$\begin{array}{l}\text { Peak discharge, in cubic feet per second, for } \\
\text { indicated recurrence interval, in years }\end{array}$} \\
\hline $\begin{array}{c}\text { R. I. } \\
\text { Discharge }\end{array}$ & 2 & 5 & 10 & 25 \\
\hline
\end{tabular}

Standard Deviation (logs): 0.257

Skewness Coefficient (logs): 0.462

\begin{tabular}{|c|cccc|}
\hline \multicolumn{4}{|c|}{ LOW-FLOW FREQUENCY } \\
\hline $\begin{array}{l}\text { Consecutive } \\
\text { day period }\end{array}$ & \multicolumn{3}{|c|}{$\begin{array}{l}\text { Discharge, in cubic feet per second for } \\
\text { indicated recurrence interval, in years }\end{array}$} \\
\hline & 2 & 5 & 10 & 20 \\
\cline { 2 - 5 } 7 & 9.6 & 6.9 & 5.8 & 5.1 \\
14 & 10.8 & 7.4 & 6.1 & 5.3 \\
30 & 13.1 & 8.6 & 6.9 & 5.8 \\
60 & 17.1 & 10.8 & 8.6 & 7.2 \\
90 & 23.8 & 13.4 & 9.9 & 7.7 \\
\hline
\end{tabular}

FLOW DURATION

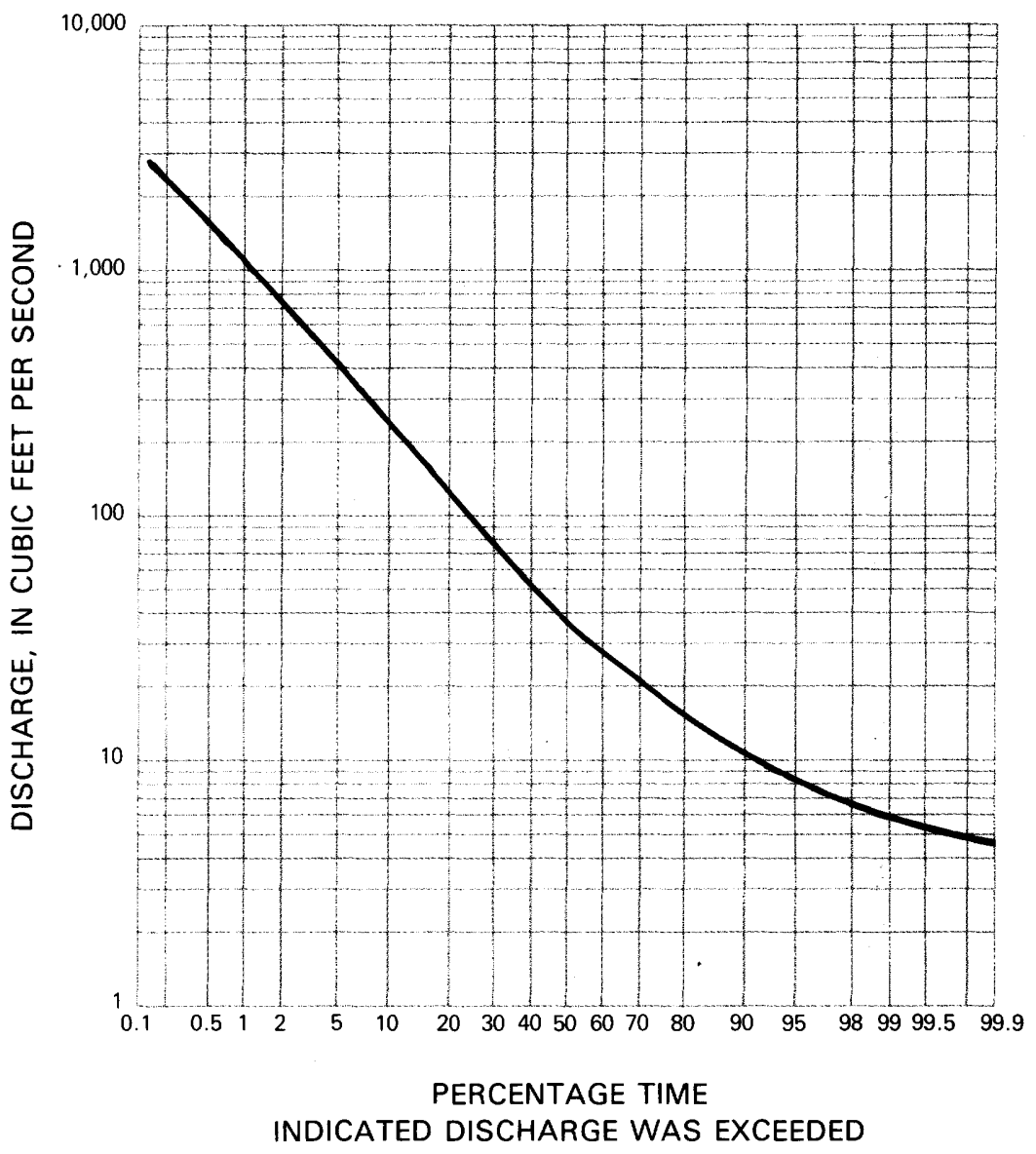



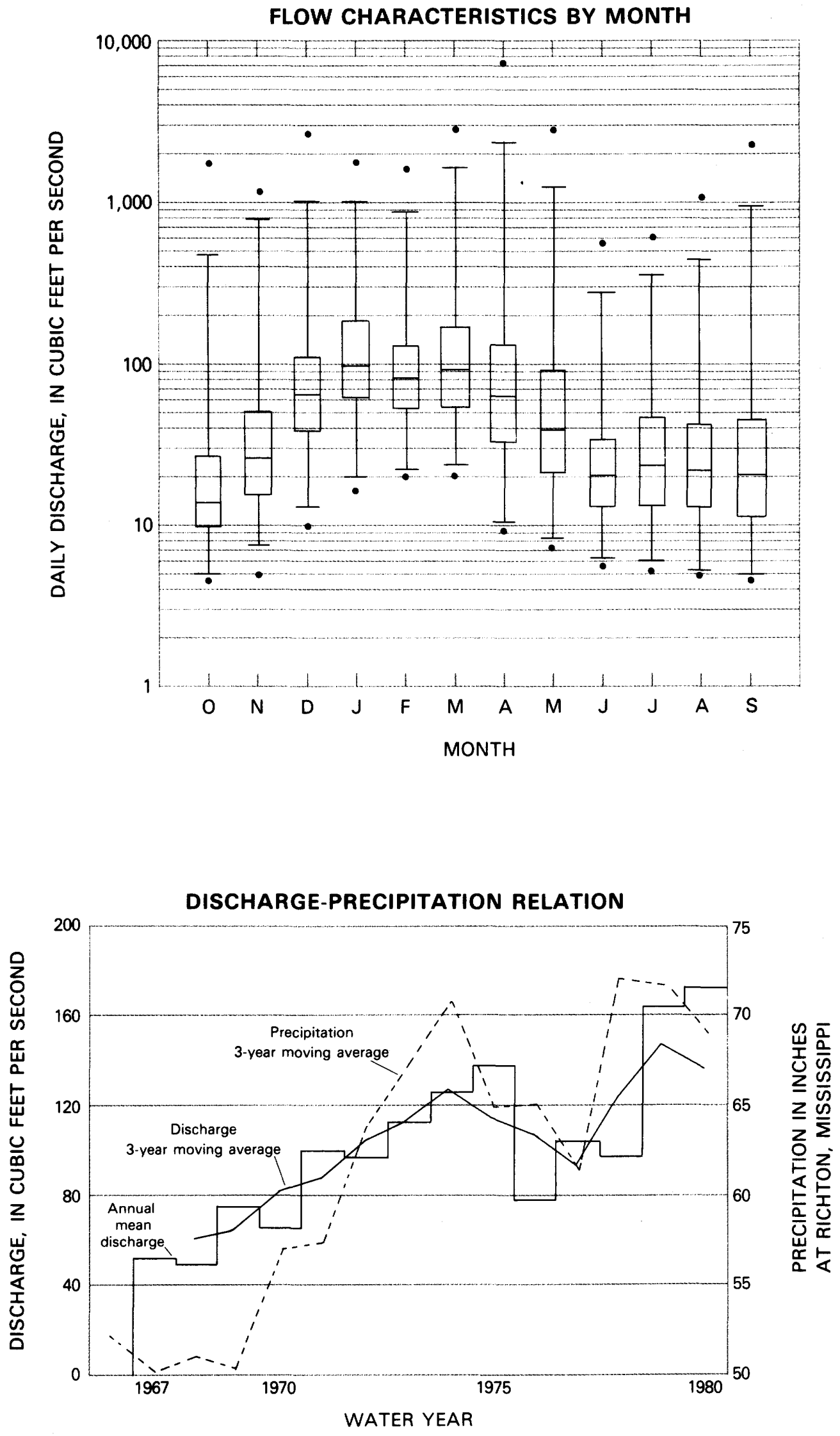
Station 26. - Rock Creek below Horse Creek near International Boundary, MT (06169500)

Location: Lat $48^{\circ} 58^{\prime} 10^{\prime \prime}$, long $106^{\circ} 50^{\prime} 20^{\prime \prime}$, Valley County, 2 mi south of international boundary, 3 mi downstream from Horse Creek and 21 mi northwest of Opheim, Mont.

Drainage area: $328 \mathrm{mi}^{2}$.

Topography: Gentle rolling prairie land ranging in elevation from about 2,500 to $3,200 \mathrm{ft}$, with a mean basin elevation of $2,870 \mathrm{ft}$ and a $12 \mathrm{ft} / \mathrm{mi}$ slope.

Rock type: Rocks in the basin consist of noncalcareous, silty clay shale of the Bearpaw Formation of Upper Cretaceous age. Bed thickness ranges from 0 to $1,370 \mathrm{ft}$.

Vegetation: Prairie grasses cover most of the basin. There is some scattered sagebrush. A few shrubs and several scattered cottonwood groves line some of the stream channel, but for all practical purposes there is no forest cover.

Manmade influences: Most of the basin lies within Canada in the province of Saskatchewan and has been designated as a Provincial Grasslands Park. There are several minor diversions for irrigation above the station.

Period of record: October 1978 to September 1980; seasonal records available 1916-26, 1956-78.

Extremes: Maximum discharge, 4,420 ft ${ }^{3} / \mathrm{s}$, April 7, 1969, gage height, $12.03 \mathrm{ft}$, maximum gage height, $13.40 \mathrm{ft}, \mathrm{March}$ 29, 1978 (backwater from ice); no flow at times most years.

Remarks: This station was designated as a hydrologic bench mark on October 1, 1978. At the same time the hydrologic bench mark, Beauvais Creek near St. Xavier, MT (05288200), was discontinued because of extreme channel erosion and very difficult measuring conditions.

Note: The record is too short to present annual mean discharge.

\section{FLOW DURATION}

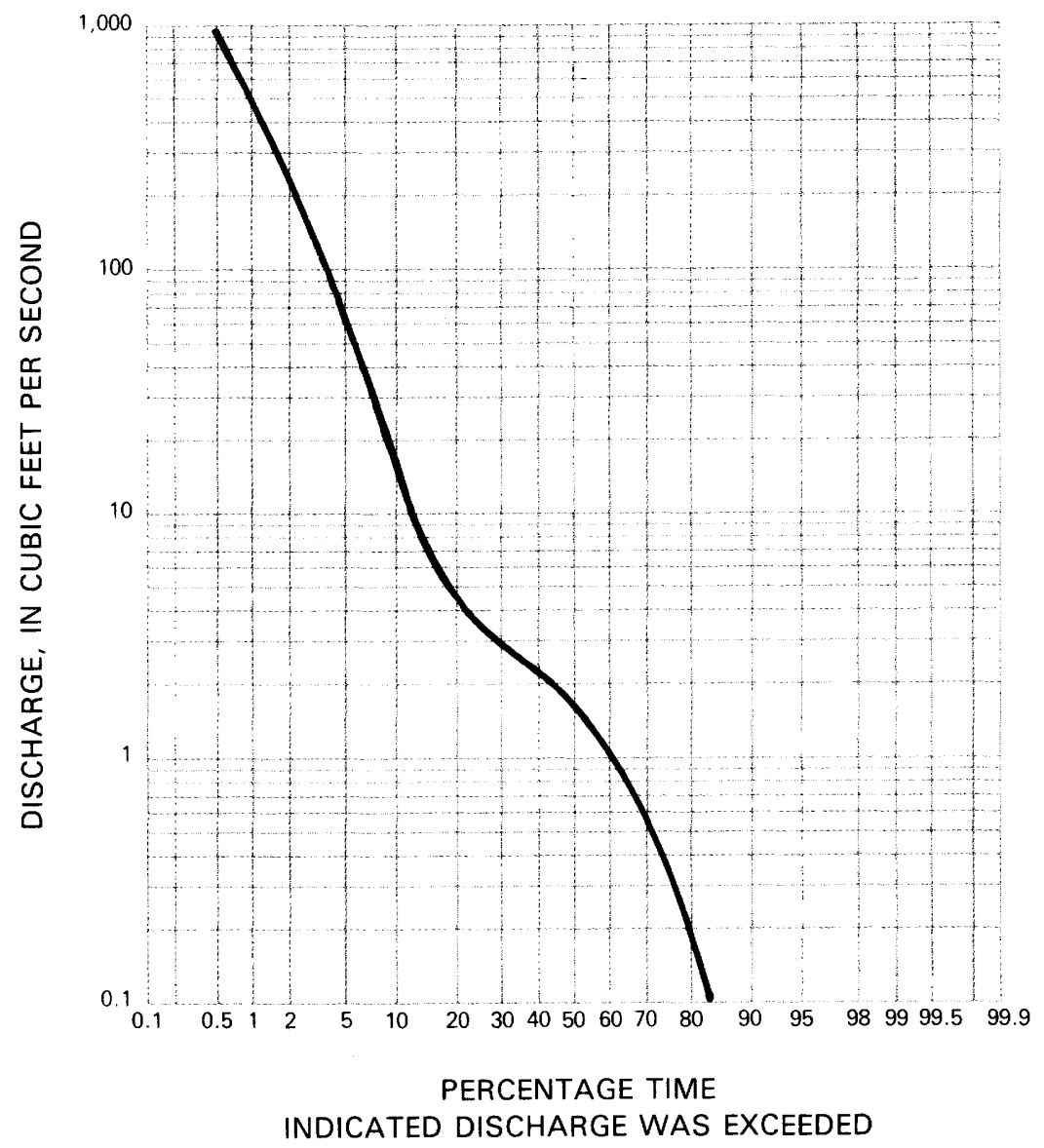




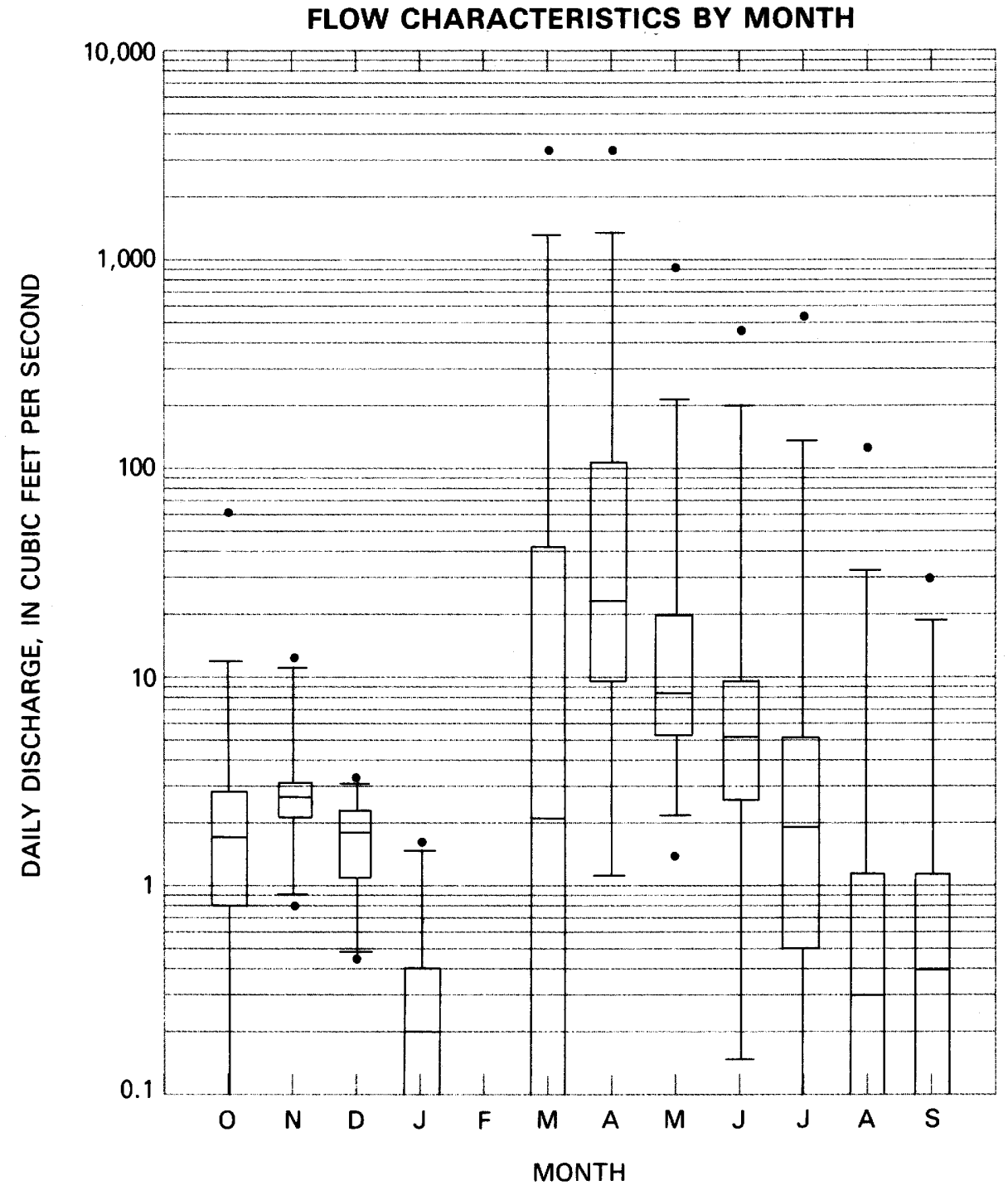


Location: Lat $48^{\circ} 47^{\prime} 57^{\prime \prime}$, long $113^{\circ} 39^{\prime} 21^{\prime \prime}$, Glacier County, at Many Glacier, 11 mi southwest of Babb.

Drainage area: $30.9 \mathrm{mi}^{2}$.

Topography: Steep mountains having many vertical rock exposures. The valleys have been modified by glaciers. Lakes make up about 5 percent of the basin area. Basin elevations range from 5,000 to 10,000 ft. Steep stream gradients are interrupted by four small natural lakes in the basin.

Rock type: Rocks in the basin consist of varicolored argillite, quartzite, and limestone; there are minor amounts of basalt in the headwaters near the Continental Divide.

Vegetation: Coniferous trees, aspen, and various shrubs inhabit the basin. There is very little grass cover. Much of the basin is sparsely covered for lack of a soil mantle.

Manmade influences: The basin is entirely within Glacier National Park. Park administrative and tourist facilities are about $1 \mathrm{mi}$ upstream from the gage. Water supply for these facilities, amounting to about 20 million gallons per year, is taken from the basin upstream from the gage. Sewage-disposal facilities are downstream from the gage.

Period of record: April 1917 to March 1920, March 1958 to September 1980; intermittent record available 1912-16, 1920-57.

Average discharge: $144 \mathrm{ft}^{3} / \mathrm{s}$.

Extremes: Maximum discharge, 6,700 ft $3 / \mathrm{s}$, June 8, 1964, gage height, $10.00 \mathrm{ft}$ from floodmarks from rating curve extended above 1,100 $\mathrm{ft}^{3} / \mathrm{s}$ on basis of computation of peak flow over dam; minimum, no flow November 14-16, 1976 (result of pumping operation).

Serial correlation coefficient for annual mean discharges: -0.319 .

Kendall's tau correlation coefficient for annual mean disharges: -0.065 .

\begin{tabular}{|c|rrrrr|}
\hline \multicolumn{6}{|c|}{ FLOOD FREQUENCY } \\
\hline \multicolumn{5}{|c|}{$\begin{array}{l}\text { Peak discharge, in cubic feet per second, for } \\
\text { indicated recurrence interval, in years }\end{array}$} \\
\hline $\begin{array}{c}\text { R. I. } \\
\text { Discharge }\end{array}$ & 2 & 5 & 10 & 50 & 100 \\
\hline
\end{tabular}

Standard Deviation (logs): 0.172

Skewness Coefficient (logs): 1.112

\begin{tabular}{|c|cccc|}
\hline \multicolumn{5}{|c|}{ LOW-FLOW FREQUENCY } \\
\hline $\begin{array}{c}\text { Consecutive } \\
\text { day period }\end{array}$ & \multicolumn{3}{|c|}{$\begin{array}{l}\text { Discharge, in cubic feet per second for } \\
\text { indicated recurrence interval, in years }\end{array}$} \\
\hline & 2 & 5 & 10 & 50 \\
\cline { 2 - 5 } 7 & 13.1 & 9.6 & 8.0 & 5.5 \\
14 & 14.0 & 11.2 & 10.0 & 8.3 \\
30 & 16.4 & 12.5 & 10.9 & 8.7 \\
60 & 20.2 & 14.6 & 12.4 & 9.5 \\
90 & 22.9 & 16.3 & 14.0 & 11.0 \\
\hline
\end{tabular}

\section{FLOW DURATION}

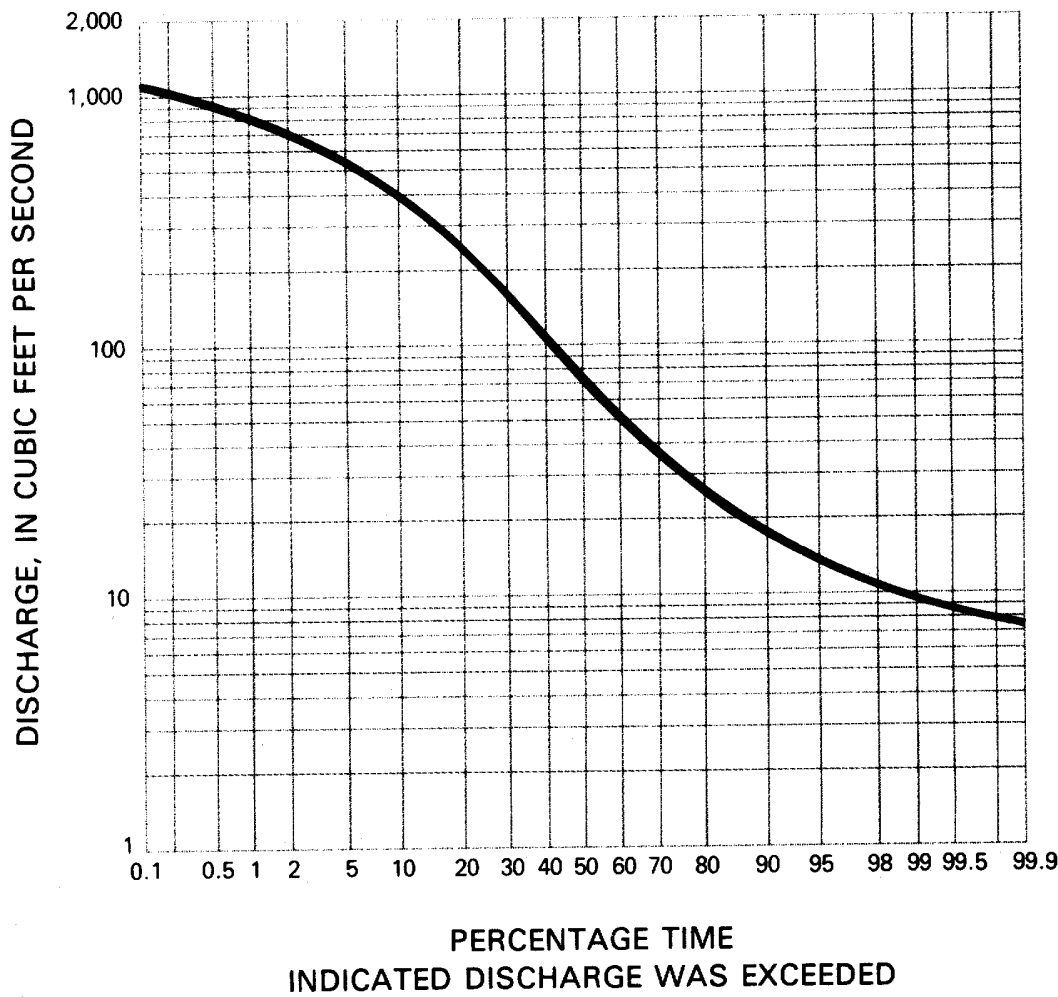



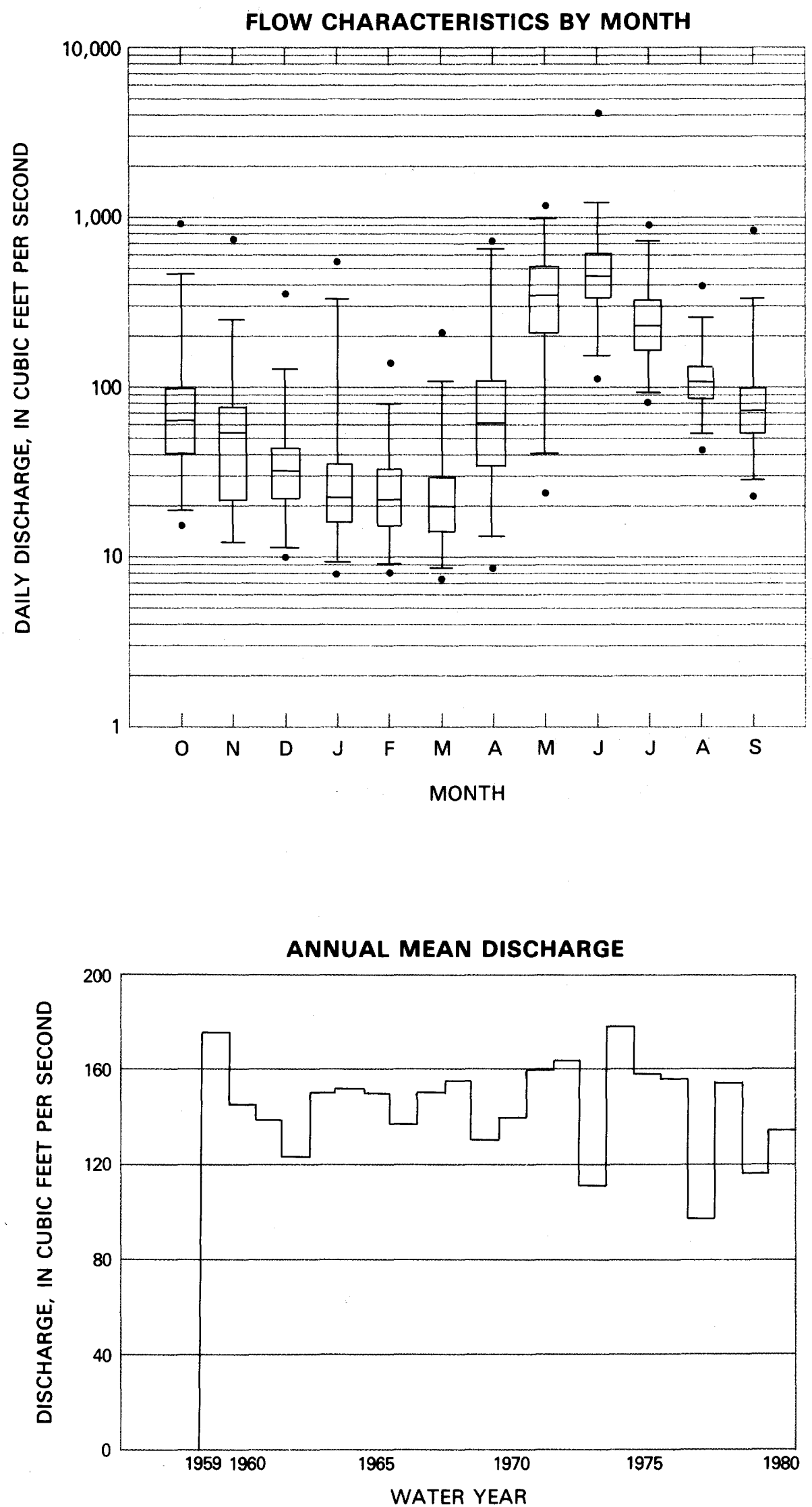
Station 28. - Dismal River near Thedford, NE (06775900)

Location: Lat $41^{\circ} 46^{\prime} 45^{\prime \prime}$, long $100^{\circ} 31^{\prime} 30^{\prime \prime}$, Thomas County, 14 mi south of Thedford.

Drainage area: $960 \mathrm{mi}^{2}$, approximately, of which about $30 \mathrm{mi}^{2}$ contributes directly to surface runoff.

Topography: Rolling to hilly sand hills. The upper end of the basin contains many small lakes. The average elevation of the divide is about $3,600 \mathrm{ft}$. Basin elevations range from 2,800 to $4,000 \mathrm{ft}$. The slope of the main stream is about $6 \mathrm{ft} / \mathrm{mi}$.

Rock type: Sand and siltstone.

Vegetation: The basin is almost entirely rangeland. A few native trees grow along the river and some windbreak tree plantings have been established.

Manmade influences: A few roads and trails traverse the basin. Some sand and gravel is pumped from areas along the river. In the last decade there has been a gradual increase in the number of center-pivot irrigation systems pumping from ground water.

Period of record: October 1966 to September 1980.

Average discharge: $192 \mathrm{ft}^{3} / \mathrm{s}$.

Extremes: Maximum discharge, $335 \mathrm{ft}^{3} / \mathrm{s}$, July 28, 1967, gage height, $2.73 \mathrm{ft}$; maximum gage height, $2.94 \mathrm{ft}$, December 31, 1968, backwater from ice; minimum daily discharge, $156 \mathrm{ft}^{3} / \mathrm{s}$, January 27, 1972.

Serial correlation coefficient for annual mean discharges: 0.058 .

Kendall's tau correlation coefficient for annual mean discharges: 0.187.

\section{FLOW DURATION}

\begin{tabular}{|c|rrrr|}
\hline \multicolumn{5}{|c|}{ FLOOD FREQUENCY } \\
\hline \multicolumn{4}{|c|}{ Peak discharge, in cubic feet per second, for } \\
indicated recurrence interval, in years \\
\hline R. I. & 2 & 5 & 10 & 25 \\
Discharge & 290 & 314 & 327 & 342 \\
\hline
\end{tabular}

Standard Deviation (logs): 0.040

Skewness Coefficient (logs): 0.115

\begin{tabular}{|c|cccc|}
\hline \multicolumn{4}{|c|}{ LOW-FLOW FREQUENCY } \\
\hline $\begin{array}{c}\text { Consecutive } \\
\text { day period }\end{array}$ & \multicolumn{3}{|c|}{$\begin{array}{c}\text { Discharge, in cubic feet per second for } \\
\text { indicated recurrence interval, in years }\end{array}$} \\
\hline & 2 & 5 & 10 & 20 \\
\cline { 2 - 5 } 7 & 173 & 169 & 167 & 165 \\
14 & 175 & 171 & 169 & 168 \\
30 & 178 & 174 & 172 & 170 \\
60 & 181 & 178 & 175 & 174 \\
90 & 183 & 180 & 178 & 177 \\
\hline
\end{tabular}

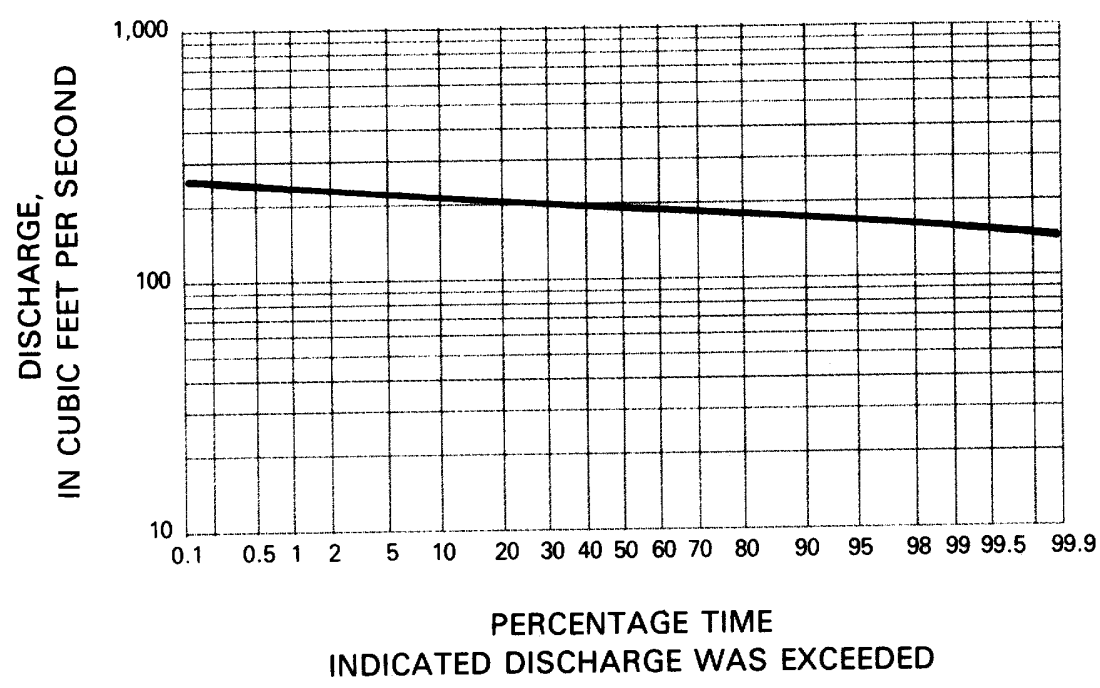



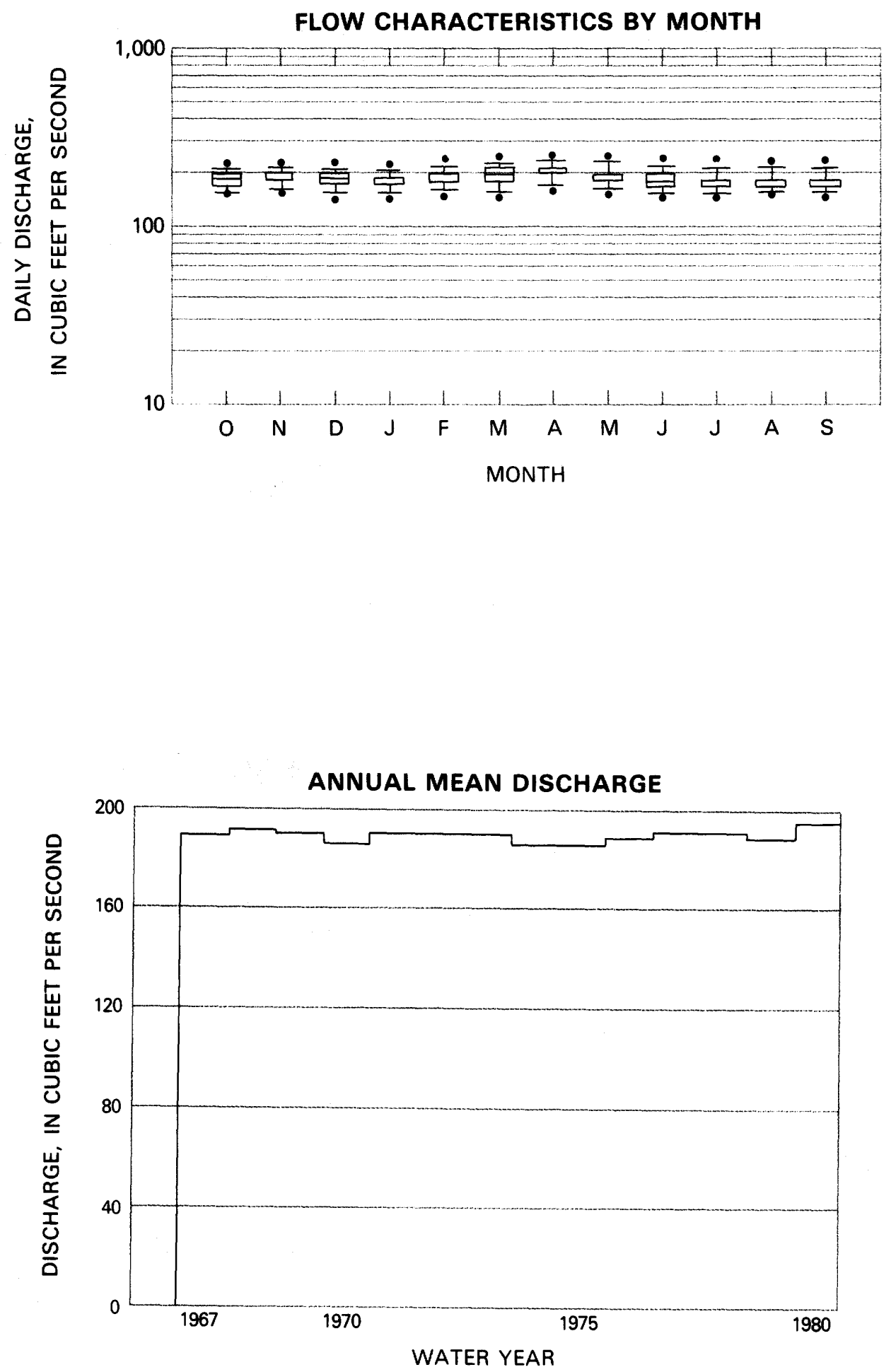
Location: Lat $38^{\circ} 53^{\prime} 15^{\prime \prime}$, long $117^{\circ} 14^{\prime} 40^{\prime \prime}$, Nye County, 15 mi northwest of Round Mountain.

Drainage area: $20 \mathrm{mi}^{2}$, approximately.

Topography: Very rough mountainous terrain that has protruding cliffs and steep slopes. Basin elevations range from 6,400 to $11,800 \mathrm{ft}$. Stream slope is about $350 \mathrm{ft} / \mathrm{mi}$.

Rock type: Consolidated limestone, shales, and undifferentiated intrusives.

Vegetation: Thin cover of pin õn pine and grass. Dense willow and alder thickets grow along the streams.

Manmade influences: Limited cattle grazing takes place in the basin. A small gold mine approximately 3 mi upstream began operation in 1980. An access road with several fords was built in April 1980.

Period of record: August 1965 to September 1980.

Average discharge: $6.6 \mathrm{ft}^{3} / \mathrm{s}$.

Extremes: Maximum discharge, $128 \mathrm{ft} \mathrm{t}^{3} / \mathrm{s}$, June 3, 1975, gage height, $3.69 \mathrm{ft}$; maximum gage height recorded, 4.26 $\mathrm{ft}$, January 30, 1979; minimum, $0.11 \mathrm{ft}^{3} / \mathrm{s}$, September 4, 1972.

Serial correlation coefficient for annual mean discharges: -0.246 .

Kendall's tau correlation coefficient for annual mean discharges: 0.314 .

\begin{tabular}{|c|rrrr|}
\hline \multicolumn{5}{|c|}{ FLOOD FREQUENCY } \\
\hline \multicolumn{4}{|c|}{$\begin{array}{c}\text { Peak discharge, in cubic feet per second, for } \\
\text { indicated recurrence interval, in years }\end{array}$} \\
\hline $\begin{array}{c}\text { R. I. } \\
\text { Discharge }\end{array}$ & 2 & 5 & 10 & 25 \\
\hline
\end{tabular}

Standard Deviation (logs): 0.342

Skewness Coefficient (logs): -0.060

\begin{tabular}{|c|cccc|}
\hline \multicolumn{5}{|c|}{ LOW-FLOW FREQUENCY } \\
\hline $\begin{array}{l}\text { Consecutive } \\
\text { day period }\end{array}$ & \multicolumn{4}{|c|}{$\begin{array}{l}\text { Discharge, in cubic feet per second for } \\
\text { indicated recurrence interval, in years }\end{array}$} \\
\hline & 2 & 5 & 10 & 20 \\
\cline { 2 - 5 } 7 & 1.3 & 0.9 & 0.8 & 0.7 \\
14 & 1.5 & 1.1 & 0.9 & 0.8 \\
30 & 1.6 & 1.2 & 1.0 & 0.9 \\
60 & 1.7 & 1.4 & 1.2 & 1.1 \\
90 & 1.8 & 1.5 & 1.4 & 1.3 \\
\hline
\end{tabular}

FLOW DURATION

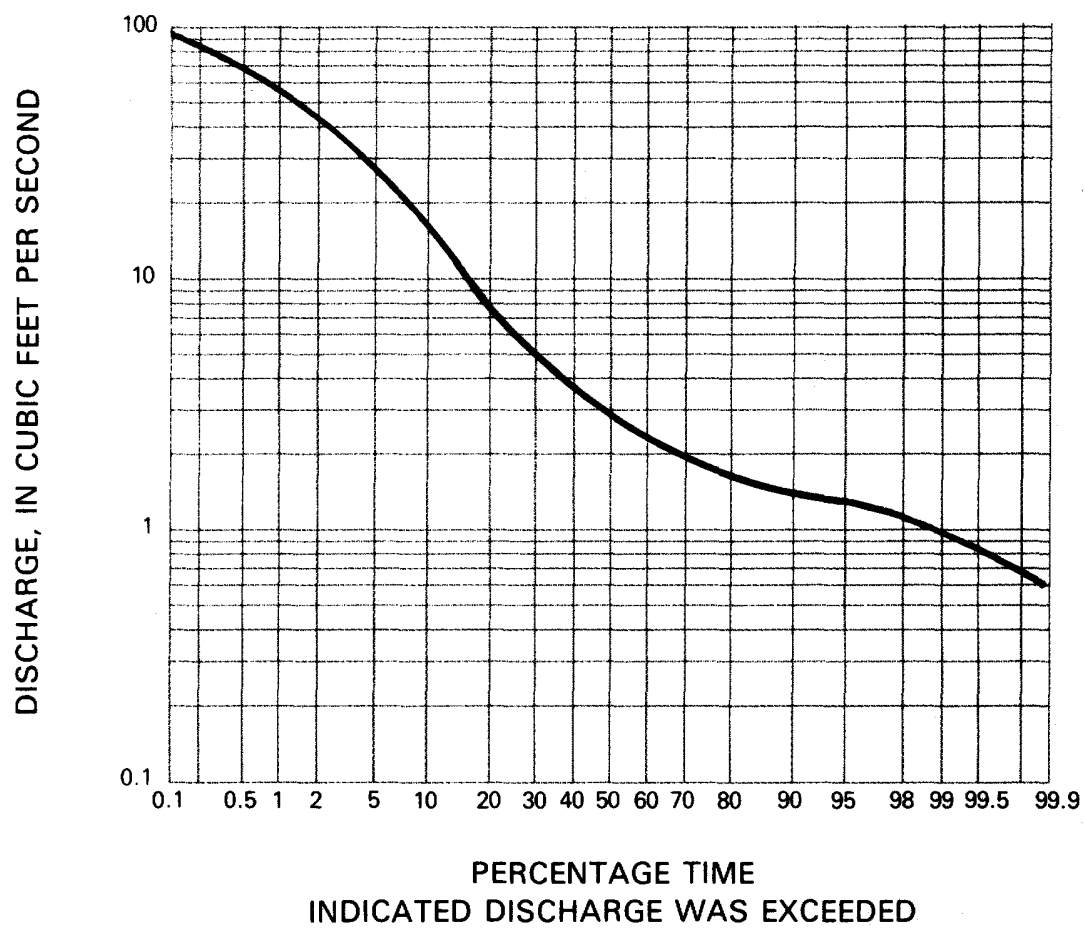



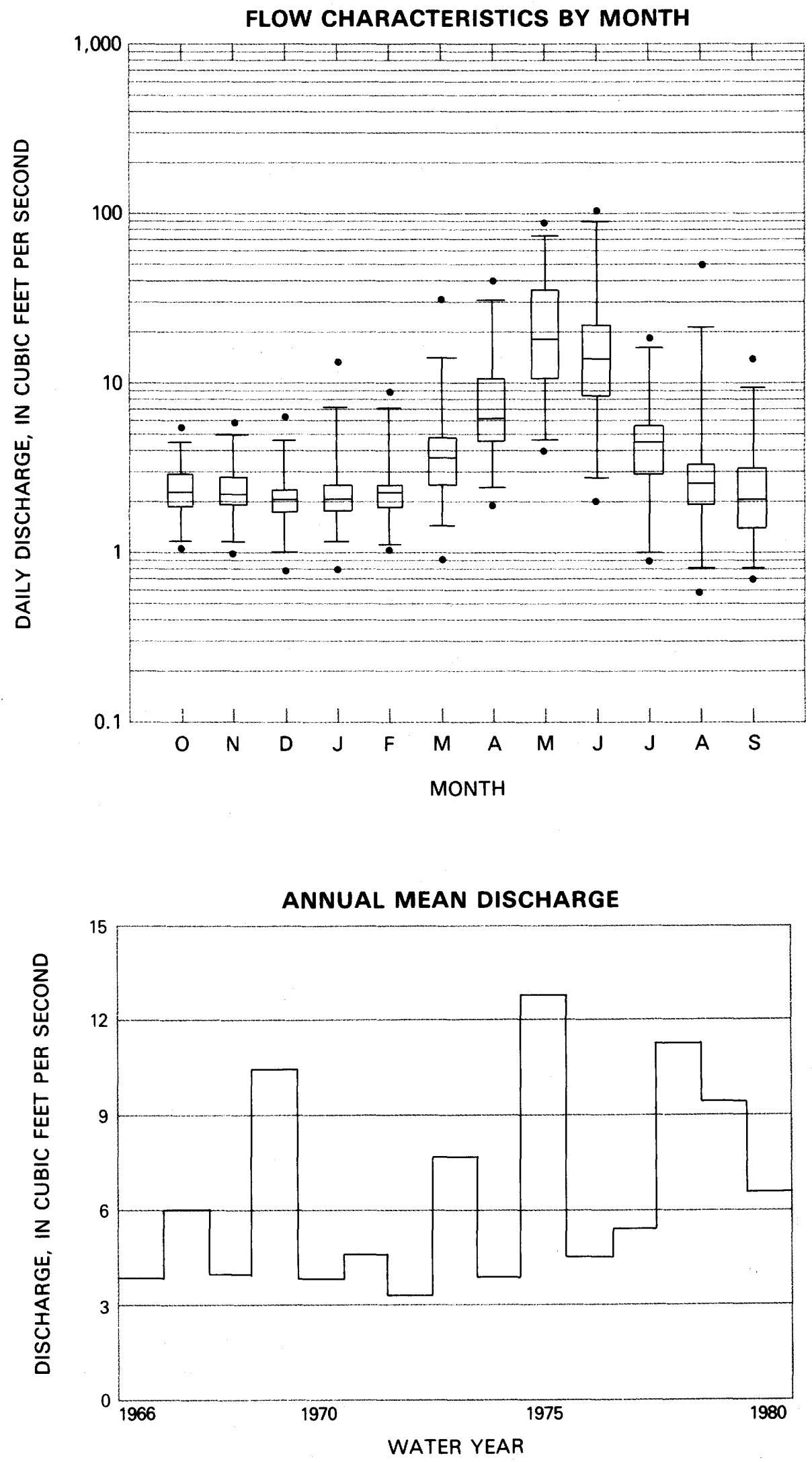
Station 30.-Steptoe Creek near Ely, NV (10244950)

Location: Lat $39^{\circ} 12^{\prime} 05^{\prime \prime}$, long $114^{\circ} 41^{\prime} 15^{\prime \prime}$, White Pine County, 11 mi east-southeast of Ely.

Drainage area: $11.1 \mathrm{mi}^{2}$.

Topography: Steep mountainous terrain. Basin elevations range from 7,440 to $10,900 \mathrm{ft}$. Stream slope is about $370 \mathrm{ft} / \mathrm{mi}$.

Rock type: Formations are primarily limestone and also some dolomite.

Vegetation: Pinõn pines and grass.

Manmade infuences: Sheep and cattle graze on parts of the upper basin. One major gravel road and several secondary roads are in the basin. Improvement of the road downstream from the gage has eased access and increased recreational activity.

Period of record: June 1966 to September 1980.

Average discharge: $7.0 \mathrm{ft}^{3} / \mathrm{s}$.

Extremes: Maximum discharge, $37 \mathrm{ft}^{3} / \mathrm{s}$, June 16, 1978, gage height, $2.69 \mathrm{ft}$; maximum gage height, $2.73 \mathrm{ft}$, June 19, 1967; minimum discharge, $2.0 \mathrm{ft}^{3} / \mathrm{s}$, December 22, 1966, March 3, 1973.

Serial correlation coefficient for annual mean discharges: -0.490 .

Kendall's tau correlation coefficient for annual mean discharges: -0.033 .

FLOW DURATION

\begin{tabular}{|c|rrrr|}
\hline \multicolumn{4}{|c|}{ FLOOD FREQUENCY } \\
\hline \multicolumn{4}{|c|}{ Peak discharge, in cubic feet per second, for } \\
indicated recurrence interval, in years \\
\hline R. I. & 2 & 5 & 10 & 25 \\
Discharge & 20 & 33 & 42 & 54 \\
\hline
\end{tabular}

Standard Deviation (logs): 0.259

Skewness Coefficient (logs): -0.178

\begin{tabular}{|c|cccc|}
\hline \multicolumn{4}{|c|}{ LOW-FLOW FREQUENCY } \\
\hline $\begin{array}{l}\text { Consecutive } \\
\text { day period }\end{array}$ & \multicolumn{3}{|c|}{$\begin{array}{c}\text { Discharge, in cubic feet per second for } \\
\text { indicated recurrence interval, in years }\end{array}$} \\
\hline & 2 & 5 & 10 & 20 \\
\cline { 2 - 5 } 7 & 3.1 & 2.7 & 2.5 & 2.4 \\
14 & 3.2 & 2.8 & 2.6 & 2.5 \\
30 & 3.4 & 2.9 & 2.7 & 2.5 \\
60 & 3.6 & 3.1 & 2.8 & 2.6 \\
90 & 3.6 & 3.1 & 2.9 & 2.6 \\
\hline
\end{tabular}

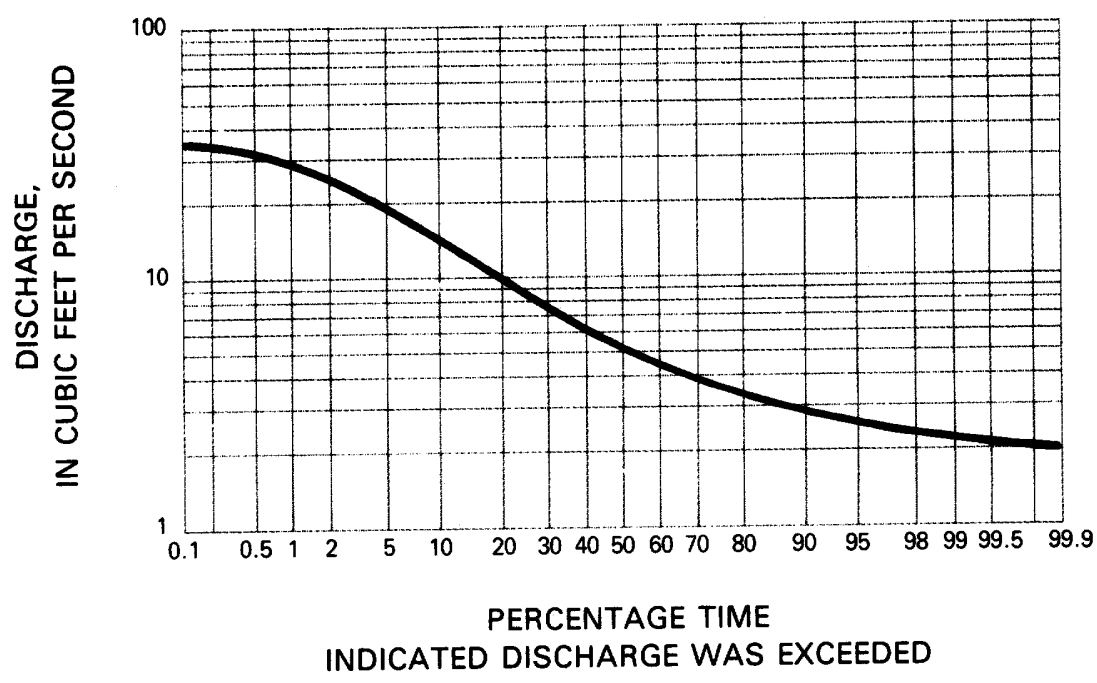



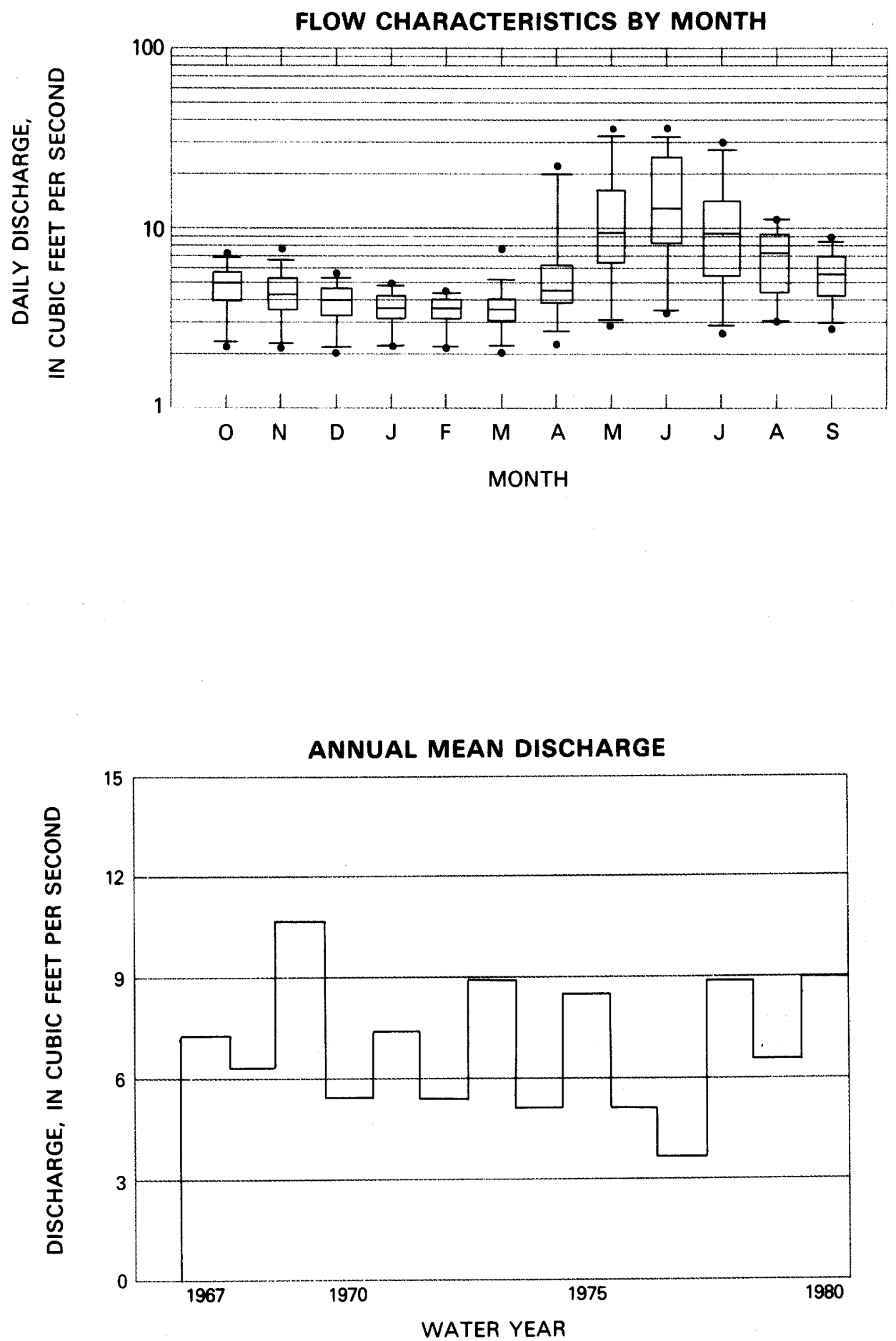
Station 31. - McDonalds Branch in Lebanon State Forest, NJ (01466500)

Location: Lat $39^{\circ} 53^{\prime} 05^{\prime \prime}$, long $74^{\circ} 30^{\prime} 20^{\prime \prime}$, Burlington County in Lebanon State Forest, 7 mi southeast of Browns Mills.

Drainage area: $2.31 \mathrm{mi}^{2}$.

Topography: Rather flat. Basin divides are low, narrow, and interrupted. Basin elevations range from 113 to $210 \mathrm{ft}$. The mean elevation is $152 \mathrm{ft}$. The main stream slope is about $12 \mathrm{ft} / \mathrm{mi}$.

Rock type: Underlying material consists of about 90 percent sand and gravel and about 10 percent clay and silt.

Vegetation: The upper 94 percent of the basin is covered with oak and pine. The lower 6 percent of the basin is covered with southern white cedar and swamp hardwoods.

Manmade influences: Occasional logging has been practiced in the basin. A railroad and a few roads traverse the basin. One gravel pit is operated in the basin. Controlled burning procedures are carried out.

Period of record: October 1953 to September 1980.

Average discharge: $2.4 \mathrm{ft}^{3} / \mathrm{s}$.

Extremes: Maximum discharge, $35 \mathrm{ft}^{3} / \mathrm{s}$, August 25, 1958, gage height, $2.33 \mathrm{ft}$; minimum daily, $0.8 \mathrm{ft}^{3} / \mathrm{s}$, July 6,1967 .

Serial correlation coefficient for annual mean discharges: 0.134 .

Kendall's tau correlation coefficient for annual mean discharges: 0.196 .

FLOW DURATION

\begin{tabular}{|c|c|c|c|c|}
\hline \multicolumn{5}{|c|}{ FLOOD FREQUENCY } \\
\hline \multicolumn{5}{|c|}{$\begin{array}{l}\text { Peak discharge, in cubic feet per second, for } \\
\text { indicated recurrence interval, in years }\end{array}$} \\
\hline $\begin{array}{c}\text { R. I. } \\
\text { Discharge }\end{array}$ & $\begin{array}{r}2 \\
11\end{array}$ & $\begin{array}{r}5 \\
18\end{array}$ & $\begin{array}{l}10 \\
23\end{array}$ & $\begin{array}{l}25 \\
40\end{array}$ \\
\hline
\end{tabular}

Standard Deviation (logs): 0.249

Skewness Coefficient (logs): 0.412

\begin{tabular}{|c|cccc|}
\hline \multicolumn{4}{|c|}{ LOW-FLOW FREQUENCY } \\
\hline $\begin{array}{c}\text { Consecutive } \\
\text { day period }\end{array}$ & \multicolumn{3}{|c|}{$\begin{array}{l}\text { Discharge, in cubic feet per second for } \\
\text { indicated recurrence interval, in years }\end{array}$} \\
\hline & 2 & 5 & 10 & 20 \\
\cline { 2 - 5 } 7 & 1.2 & 1.0 & 1.0 & 0.9 \\
14 & 1.2 & 1.0 & 1.0 & 0.9 \\
30 & 1.3 & 1.1 & 1.0 & 0.9 \\
60 & 1.4 & 1.1 & 1.0 & 0.9 \\
90 & 1.5 & 1.2 & 1.1 & 0.9 \\
\hline
\end{tabular}

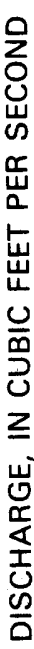

100

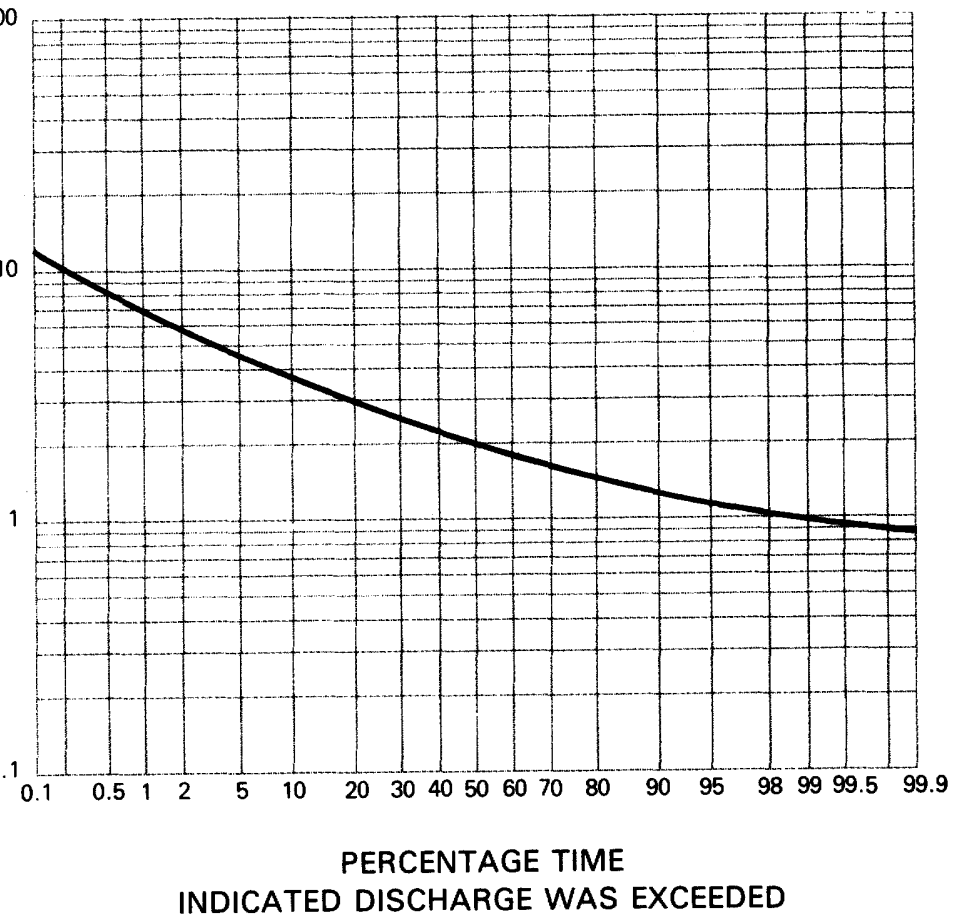



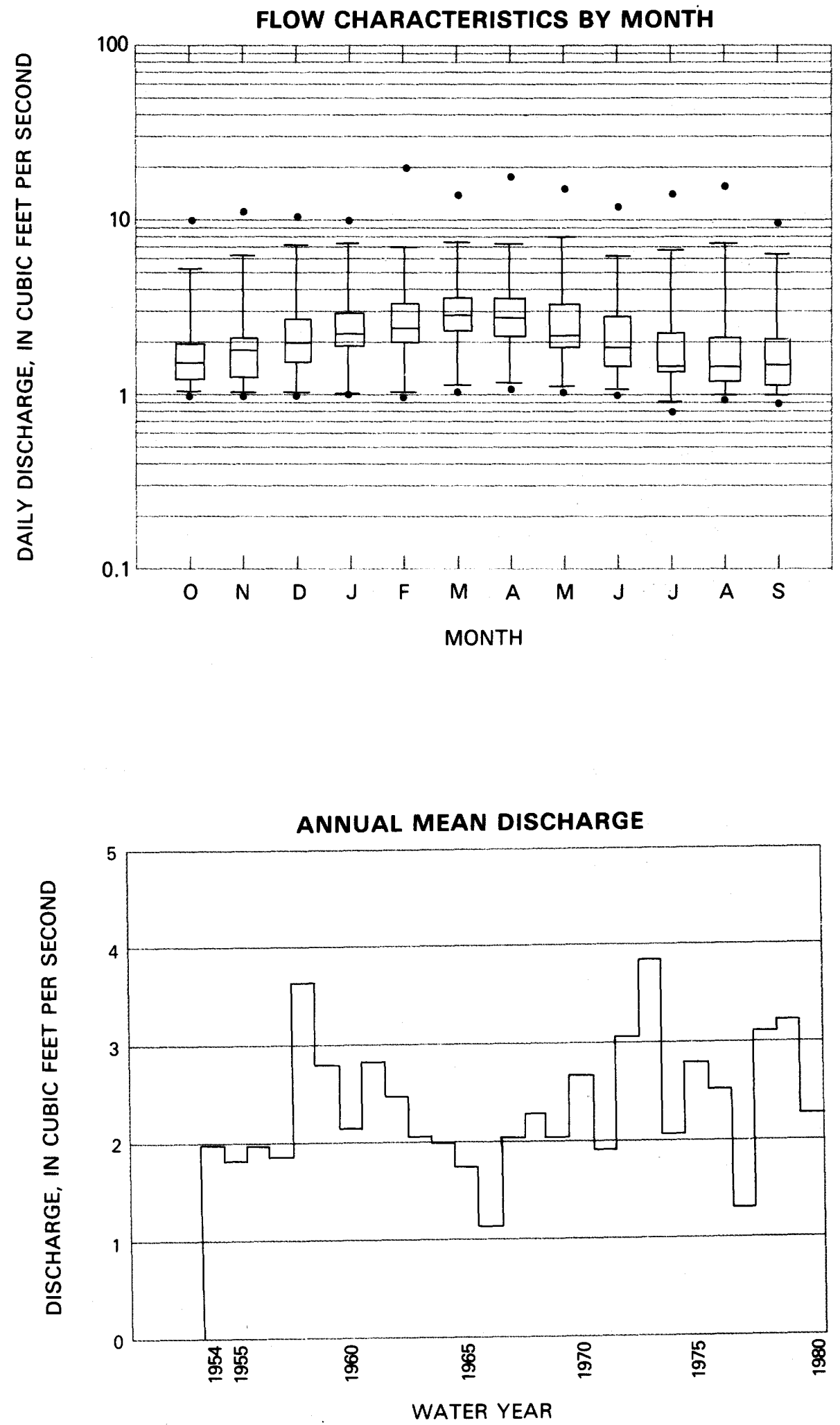
Station 32.-Mogollon Creek near Cliff, NM (09430600)

Location: Lat $33^{\circ} 10^{\prime} 01^{\prime \prime}$, long $108^{\circ} 38^{\prime} 58^{\prime \prime}$, Grant County, 14.0 mi north of Cliff.

Drainage area: $69 \mathrm{mi}^{2}$.

Topography: Steep and mountainous. Basin elevations range from 5,500 to $10,778 \mathrm{ft}$. The stream slope varies from $30 \mathrm{ft} / \mathrm{mi}$ at the gage to about $1,000 \mathrm{ft} / \mathrm{mi}$ upstream from the gage.

Rock type: Volcanic and quartz latites.

Vegetation: Pine and spruce occur at the higher elevations, while juniper, cottonwood, and willow occur at lower elevations. The cover is moderately dense in the upper elevations and very sparse in the lower elevations.

Manmade influences: Man's influence on the basin is insignificant. Most of the basin is in the Gila Wilderness Area.

Period of record: March 1967 to September 1980.

Average discharge: $30.9 \mathrm{ft}^{3} / \mathrm{s}$.

Extremes: Maximum discharge, 10,800 ft ${ }^{3} / \mathrm{s}$, August 12, 1967, gage height, $13.7 \mathrm{ft}$, from floodmarks, from rating curve extended above $220 \mathrm{ft}^{3} / \mathrm{s}$ on basis of slope-area measurement of peak flow; no flow at times.

Serial correlation coefficient for annual mean discharges: -0.074 .

Kendall's tau correlation coefficient for annual mean discharges: 0.179 .

\section{FLOW DURATION}

\begin{tabular}{|c|c|c|c|c|}
\hline \multicolumn{5}{|c|}{ FLOOD FREQUENCY } \\
\hline \multicolumn{5}{|c|}{$\begin{array}{l}\text { Peak discharge, in cubic feet per second, for } \\
\text { indicated recurrence interval, in years }\end{array}$} \\
\hline $\begin{array}{c}\text { R. I. } \\
\text { Discharge }\end{array}$ & $\begin{array}{r}2 \\
1,020\end{array}$ & $\begin{array}{r}5 \\
3,680\end{array}$ & $\begin{array}{r}10 \\
7,070\end{array}$ & $\begin{array}{r}25 \\
14,000\end{array}$ \\
\hline
\end{tabular}

Standard Deviation (logs): 0.679

Skewness Coefficient (logs): -0.146

\begin{tabular}{|c|llll|}
\hline \multicolumn{5}{|c|}{ LOW-FLOW FREQUENCY } \\
\hline $\begin{array}{c}\text { Consecutive } \\
\text { day period }\end{array}$ & \multicolumn{4}{|c|}{$\begin{array}{l}\text { Discharge, in cubic feet per second for } \\
\text { indicated recurrence interval, in years }\end{array}$} \\
\hline & 2 & 5 & 10 & 20 \\
\cline { 2 - 5 } 7 & 0 & 0 & 0 & 0 \\
14 & 0 & 0 & 0 & 0 \\
30 & 0.1 & 0 & 0 & 0 \\
60 & 0.6 & 0.2 & 0 & 0 \\
90 & 1.1 & 0.5 & 0.3 & 0.2 \\
\hline
\end{tabular}

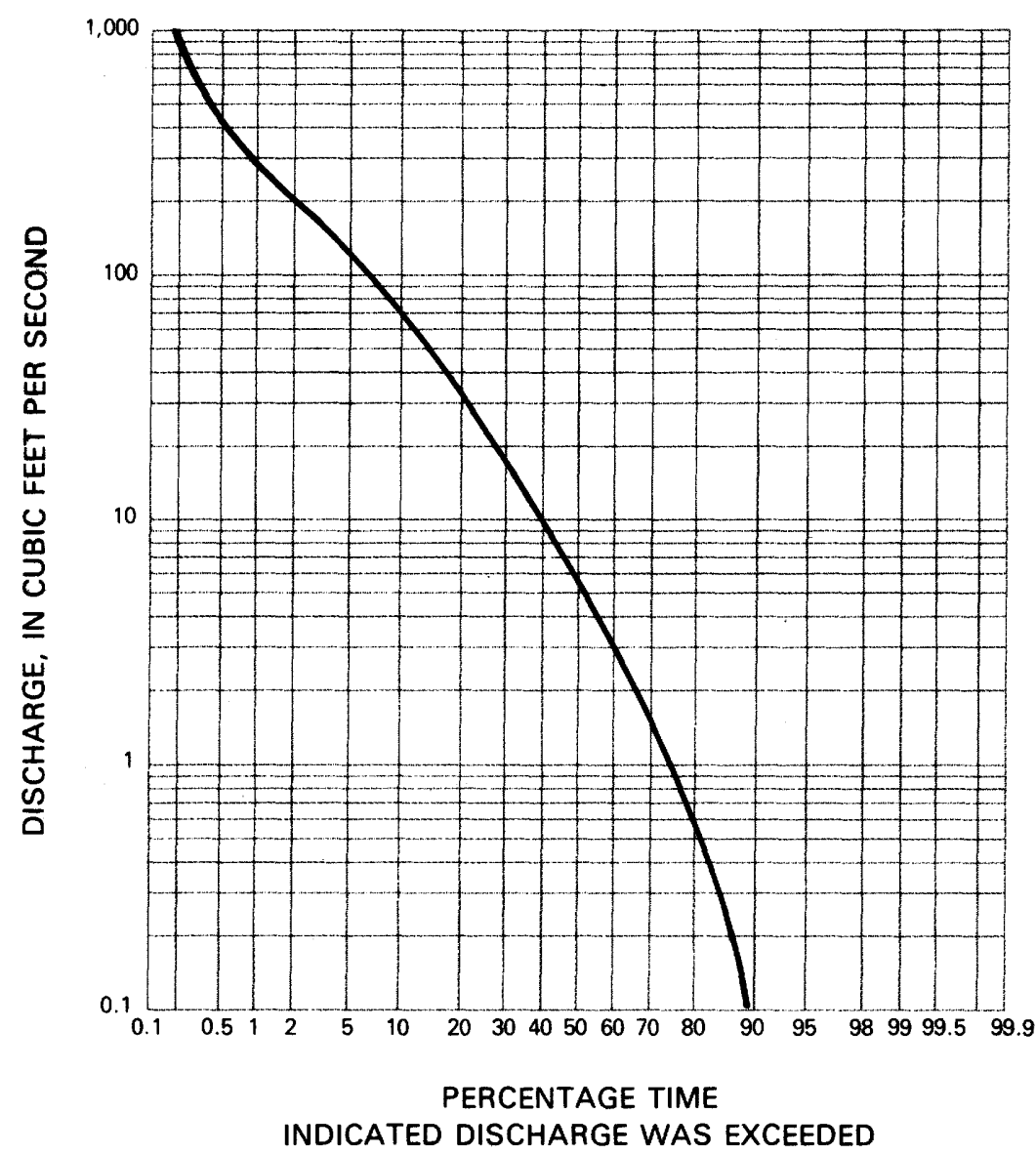



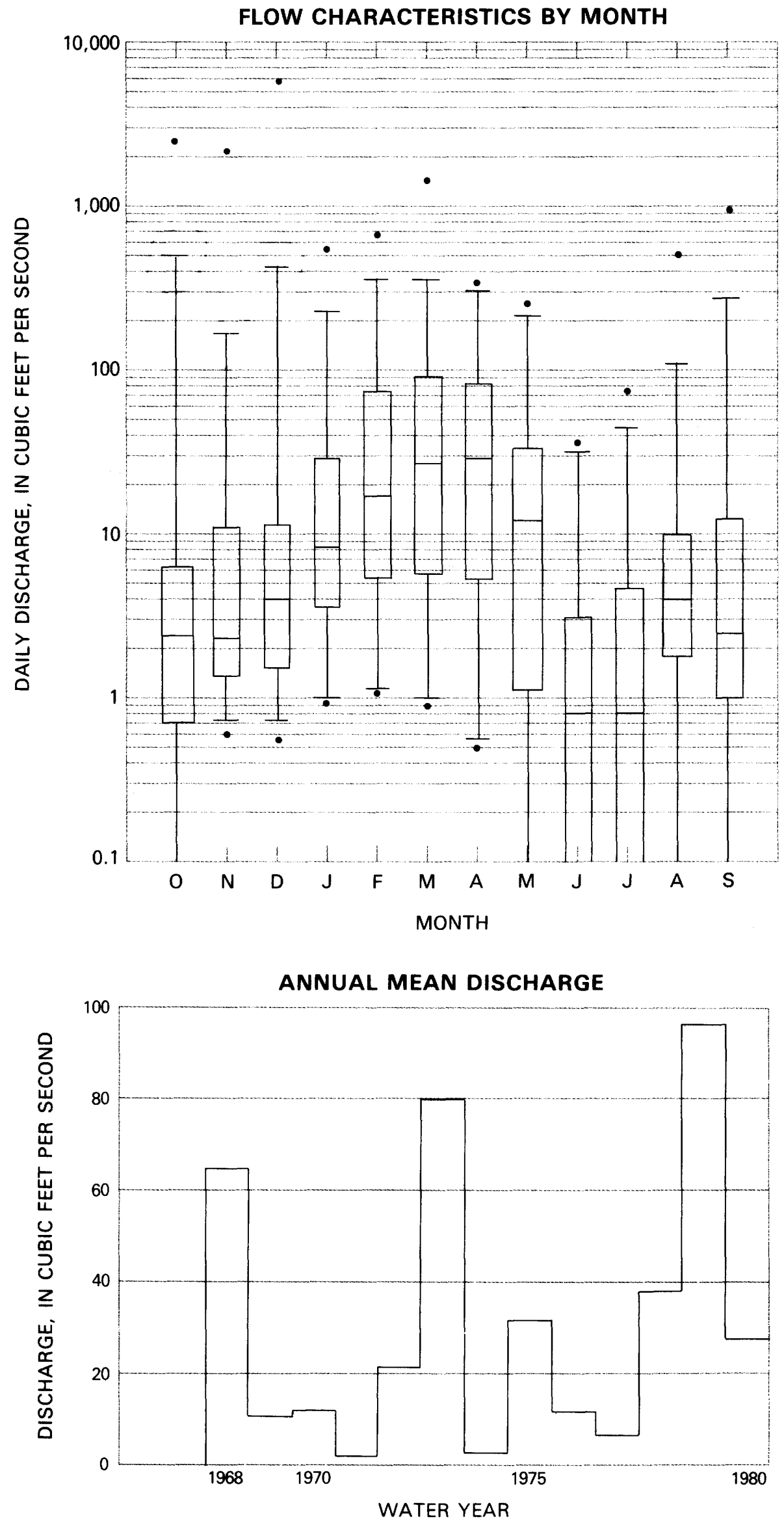
Station 33.-Rio Mora near Tererro, NM (08377900)

Location: Lat $35^{\circ} 46^{\prime} 38^{\prime \prime}$, long $105^{\circ} 39^{\prime} 27^{\prime \prime}$, San Miguel County, 2.6 mi north of Tererro.

Drainage area: $53.2 \mathrm{mi}^{2}$.

Topography: Mountainous. Basin elevations range from 8,000 to $12,944 \mathrm{ft}$. Stream slope varies from $100 \mathrm{ft} / \mathrm{mi}$ in open areas to about $300 \mathrm{ft} / \mathrm{mi}$ in canyon sections.

Rock type: Beds of siltstone, sandstone, shale, and limestone crop out on the slopes of the basin. Coarse alluvium consisting mainly of pebbles and boulders of igneous and metamorphic rocks has accumulated near the mouth of the basin.

Vegetation: About 80 percent of the basin is covered by pine, spruce, and fir. Some large aspen groves occur in the basin. The south slopes of the lower reaches are covered with scrub oak. There are a few high mountain meadows in the upper parts of the basin.

Manmade influences: Backpacking and grazing are the dominant uses within the basin. The limited cattle grazing is only by permit. About 90 percent of the basin is in the Pecos Wilderness Area.

Period of record: October 1963 to September 1980.

Average discharge: $29.0 \mathrm{ft}^{3} / \mathrm{s}$.

Extremes: Maximum discharge, $820 \mathrm{ft}^{3} / \mathrm{s}$, June 8,1979 , gage height, $4.15 \mathrm{ft}$; minimum determined, $0.90 \mathrm{ft}^{3} / \mathrm{s}$, January $12-14,1964$, but may have been less during periods of ice effect.

Serial correlation coefficient for annual mean discharges: -0.326 .

Kendall's tau correlation coefficient for annual mean discharges: 0.015 .

\begin{tabular}{|c|rrrr|}
\hline \multicolumn{5}{|c|}{ FLOOD FREQUENCY } \\
\hline \multicolumn{4}{|c|}{$\begin{array}{c}\text { Peak discharge, in cubic feet per second, for } \\
\text { indicated recurrence interval, in years }\end{array}$} \\
\hline $\begin{array}{rrrrr}\text { R. I. } \\
\text { Discharge }\end{array}$ & 2 & 5 & 10 & 25 \\
\hline
\end{tabular}

Standard Deviation (logs): 0.305

Skewness Coefficient (logs): 0.105

\begin{tabular}{|c|cccc|}
\hline \multicolumn{4}{|c|}{ LOW-FLOW FREQUENCY } \\
\hline $\begin{array}{c}\text { Consecutive } \\
\text { day period }\end{array}$ & \multicolumn{4}{|c|}{$\begin{array}{l}\text { Discharge, in cubic feet per second for } \\
\text { indicated recurrence interval, in years }\end{array}$} \\
\hline & 2 & 5 & 10 & 20 \\
\cline { 2 - 5 } 7 & 3.7 & 3.0 & 2.7 & 2.5 \\
14 & 4.0 & 3.3 & 3.0 & 2.8 \\
30 & 4.3 & 3.6 & 3.3 & 3.1 \\
60 & 4.6 & 3.8 & 3.5 & 3.3 \\
90 & 5.0 & 4.1 & 3.8 & 3.5 \\
\hline
\end{tabular}

FLOW DURATION

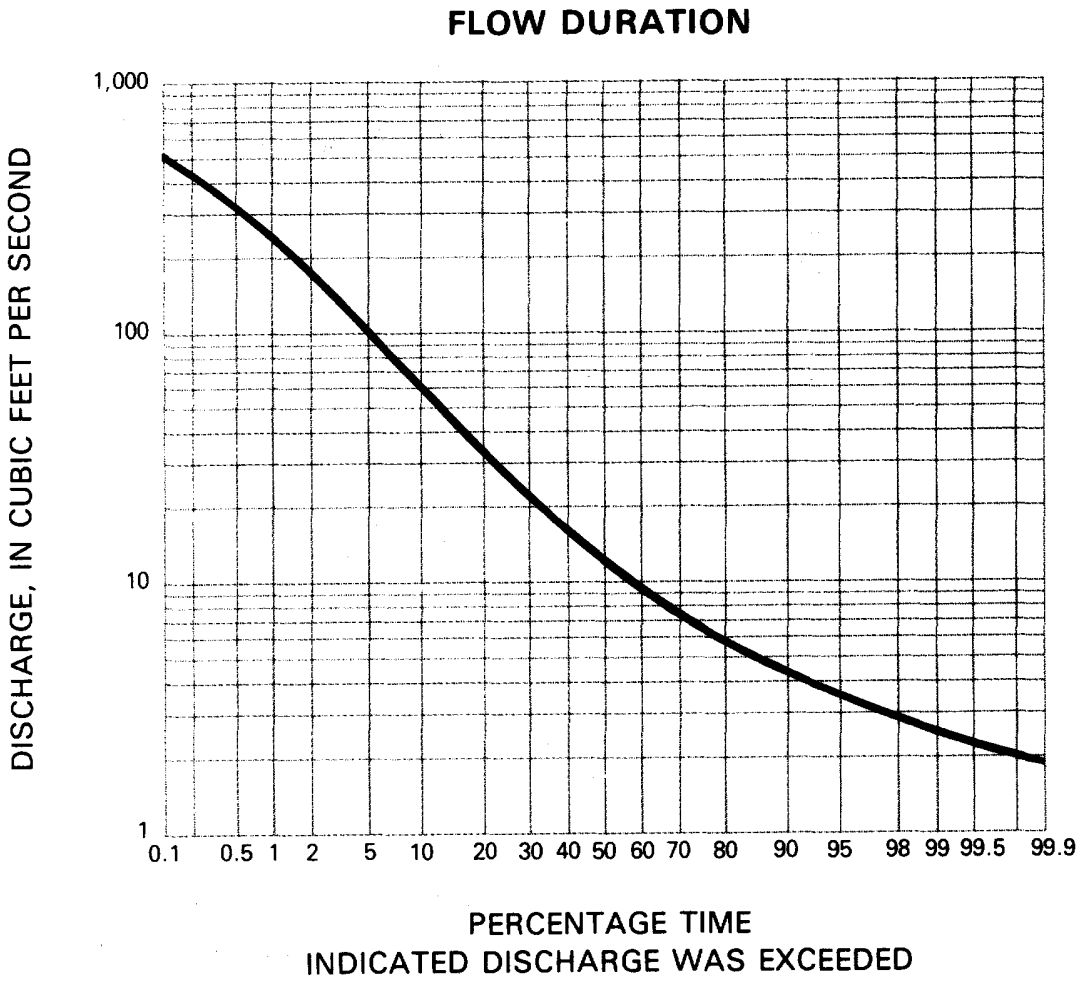



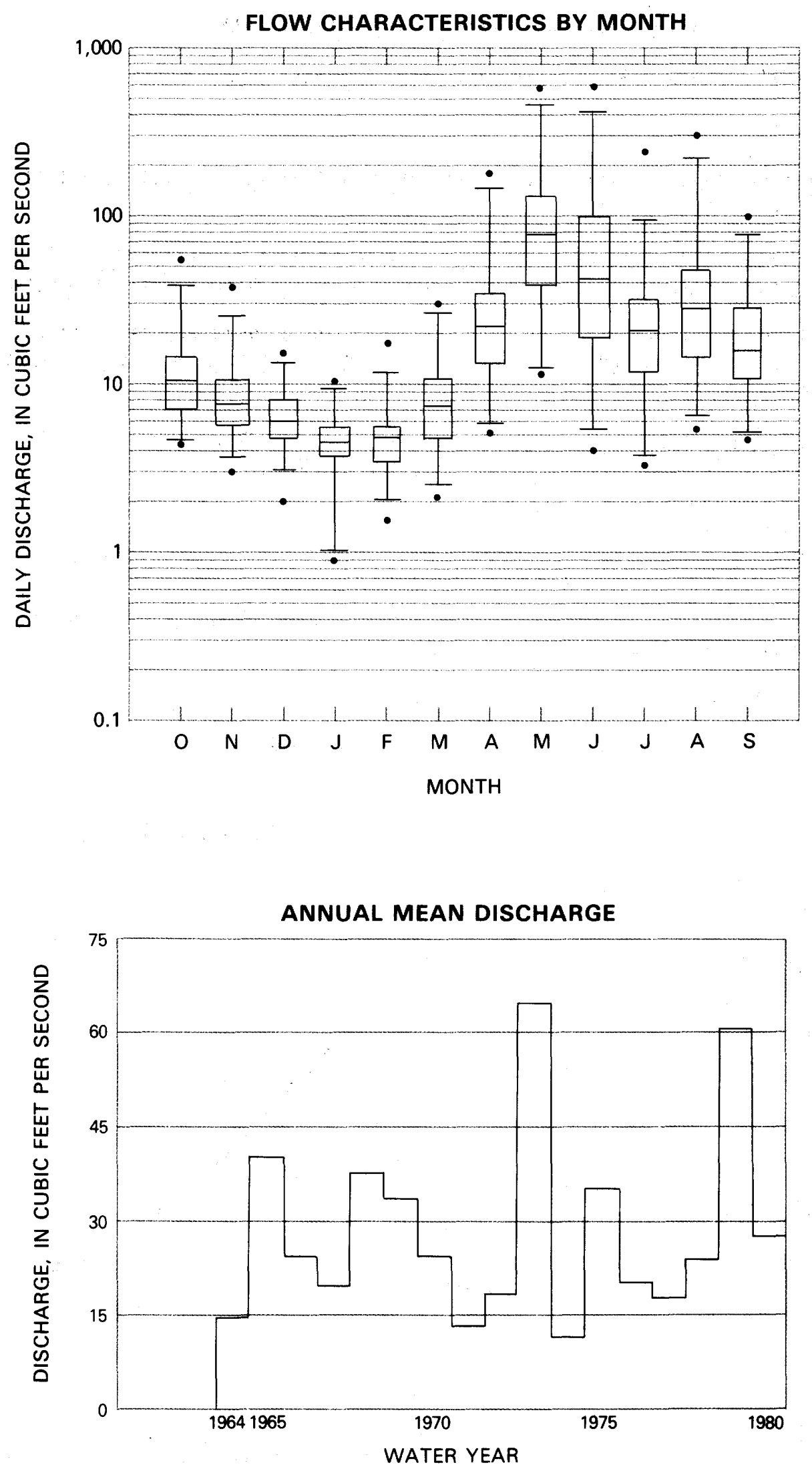
Location: Lat $42^{\circ} 06^{\prime} 59^{\prime \prime}$, long $74^{\circ} 23^{\prime} 20^{\prime \prime}$, Ulster County, at Shandaken.

Drainage area: $59.5 \mathrm{mi}^{2}$.

Topography: Mountainous. Basin elevations range from 1,017 to 3,760 ft. Stream slopes range from 73 to $350 \mathrm{ft} / \mathrm{mi}$.

Rock type: The basin is underlain by a reddish, nonmarine sandstone. Except in the narrow stream valleys, glacial till, 10 to several tens of feet in thickness, covers the sandstone. The valleys contain a variety of glacial and alluvial deposits of Holocene age as much as $200 \mathrm{ft}$ or more in thickness.

Vegetation: Except for a quarter mile cleared strip in the valley of the main stream and the two principal tributaries, the basin is densely forested with conifers and hardwoods.

Manmade influences: Some small communities and many scattered homes are along the streams in the basin. One community maintains a sewage-treatment plant. There is considerable recreational use of water, including the development of offstream ponds, in the basin.

Period of record: October 1963 to September 1980.

Average discharge: $144 \mathrm{ft}^{3} / \mathrm{s}$.

Extremes: Maximum discharge, 15,900 ft $\mathrm{f}^{3} / \mathrm{s}$, March 21, 1980, gage height, $13.00 \mathrm{ft}$ from floodmarks, from rating curve extended above $2,200 \mathrm{ft}^{3} / \mathrm{s}$ on basis of slope-area measurement at gage height $10.88 \mathrm{ft}$; minimum, $2.8 \mathrm{ft}^{3} / \mathrm{s}$, November $22,23,1964$, result of freezeup, gage height, $4.15 \mathrm{ft}$.

Serial correlation coefficient for annual mean discharges: 0.607.

Kendall's tau correlation coefficient for annual mean discharges: 0.559 .

\section{FLOW DURATION}

\begin{tabular}{|c|rrrr|}
\hline \multicolumn{4}{|c|}{ FLOOD FREQUENCY } \\
\hline \multicolumn{4}{|c|}{$\begin{array}{l}\text { Peak discharge, in cubic feet per second, for } \\
\text { indicated recurrence interval, in years }\end{array}$} \\
\hline $\begin{array}{c}\text { R. I. } \\
\text { Discharge }\end{array}$ & 2 & 5 & 10 & 25 \\
\hline
\end{tabular}

Standard Deviation (logs): 0.324

Skewness Coefficient (logs): 0.125

LOW-FLOW FREQUENCY

\begin{tabular}{|r|cccc|}
\hline \multicolumn{5}{|c|}{ LOW-FLOW FREQUENCY } \\
\hline $\begin{array}{l}\text { Consecutive } \\
\text { day period }\end{array}$ & \multicolumn{3}{|c|}{$\begin{array}{l}\text { Discharge, in cubic feet per second for } \\
\text { indicated recurrence interval, in years }\end{array}$} \\
\hline & 2 & 5 & 10 & 20 \\
\cline { 2 - 5 } 7 & 9.0 & 6.1 & 5.0 & 4.2 \\
14 & 10.1 & 6.7 & 5.4 & 4.6 \\
30 & 12.3 & 7.9 & 6.2 & 5.0 \\
60 & 16.3 & 9.8 & 7.3 & 5.7 \\
90 & 22.5 & 12.9 & 9.2 & 6.8 \\
\hline
\end{tabular}

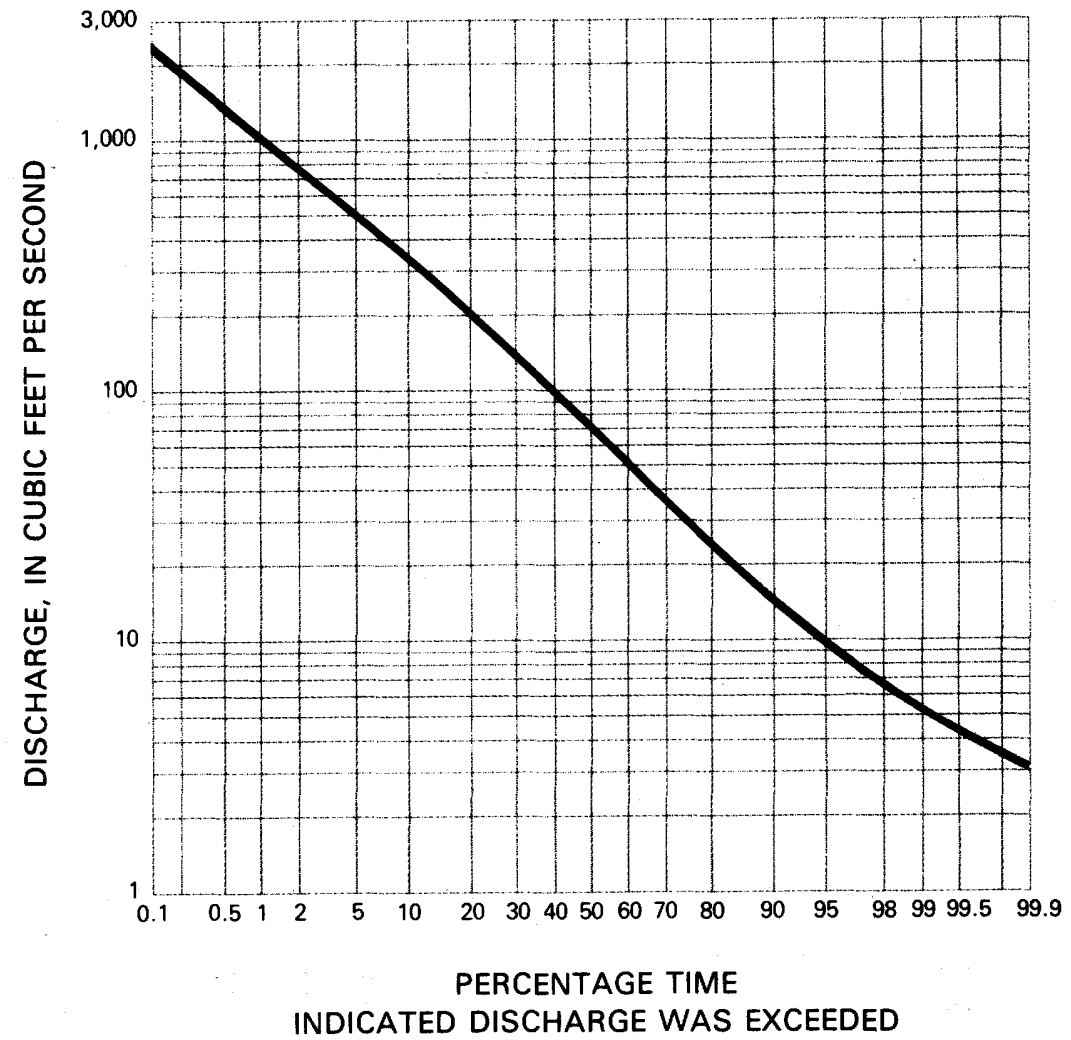



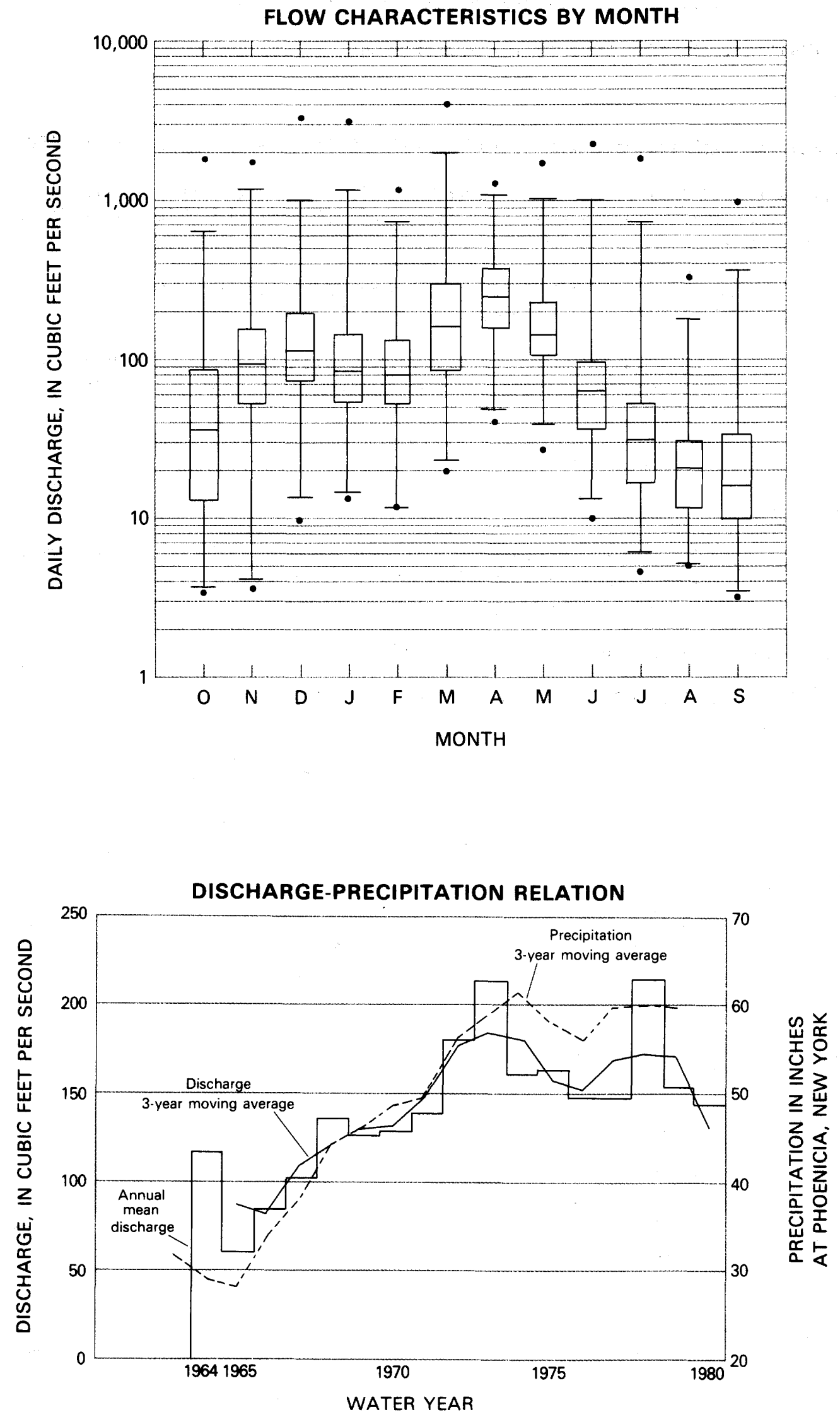
Station 35. - Cataloochee Creek near Cataloochee, NC (03460000)

Location: Lat $35^{\circ} 40^{\prime} 02^{\prime \prime}$, long $83^{\circ} 04^{\prime} 23^{\prime \prime}$, Haywood County, 2 mi north of Cataloochee.

Drainage area: $49.2 \mathrm{mi}^{2}$.

Topography: Mountainous. Basin elevations range from 2,460 to $6,120 \mathrm{ft}$. Stream slope is about $160 \mathrm{ft} / \mathrm{mi}$.

Rock type: Underlying rocks are mainly metamorphosed sandstone and shale. The stream heads in coarse-grained sandstone and crosses alternating beds of feldspathic quartzite, sandstone, and phyllite.

Vegetation: The entire basin is covered with forest. Second-growth oaks, hickory, tulip, hemlock, spruce, and balsam are the dominant trees in the basin. The undergrowth is mainly rhododendron and mountain laurel. The cover over the entire basin is very dense.

Manmade influences: The entire basin lies within the Great Smoky Mountains National Park. The basin was logged and some mining was done during the 1920's. A few roads providing access for recreational use cross the basin.

Period of record: October 1933 to September 1952, October 1962 to September 1980.

Average discharge: $111 \mathrm{ft}^{3} / \mathrm{s}$

Extremes: Maximum discharge, $5,080 \mathrm{ft}^{3} / \mathrm{s}$, March 6, 1963, gage height, $8.08 \mathrm{ft}$; minimum, $9 \mathrm{ft}^{3} / \mathrm{s}$, January 2, 1940, December 17, 24, 1943, gage height, $1.87 \mathrm{ft}$, result of freezeup.

Serial correlation coefficient for annual mean discharges: 0.350 .

Kendall's tau correlation coefficient for annual mean discharges: 0.184.

\section{FLOW DURATION}

\begin{tabular}{|c|rrrrr|}
\hline \multicolumn{7}{|c|}{ FLOOD FREQUENCY } \\
\hline \multicolumn{5}{|c|}{ Peak discharge, in cubic feet per second, for } \\
indicated recurrence interval, in years \\
\hline $\begin{array}{c}\text { R. I. } \\
\text { Discharge }\end{array}$ & 2 & 5 & 10 & 50 & 100 \\
\hline
\end{tabular}

Standard Deviation (logs): 0.195

Skewness Coefficient (logs): 0.063

\begin{tabular}{|c|ccccc|}
\hline \multicolumn{5}{|c|}{ LOW-FLOW FREQUENCY } \\
\hline $\begin{array}{c}\text { Consecutive } \\
\text { day period }\end{array}$ & \multicolumn{4}{|c|}{$\begin{array}{l}\text { Discharge, in cubic feet per second for } \\
\text { indicated recurrence interval, in years }\end{array}$} \\
\hline & 2 & 5 & 10 & 50 & 100 \\
\cline { 2 - 6 } 7 & 31 & 25 & 22 & 18 & 17 \\
14 & 33 & 26 & 23 & 19 & 17 \\
30 & 36 & 28 & 25 & 19 & 17 \\
60 & 41 & 32 & 28 & 22 & 20 \\
90 & 46 & 34 & 30 & 23 & 21 \\
\hline
\end{tabular}

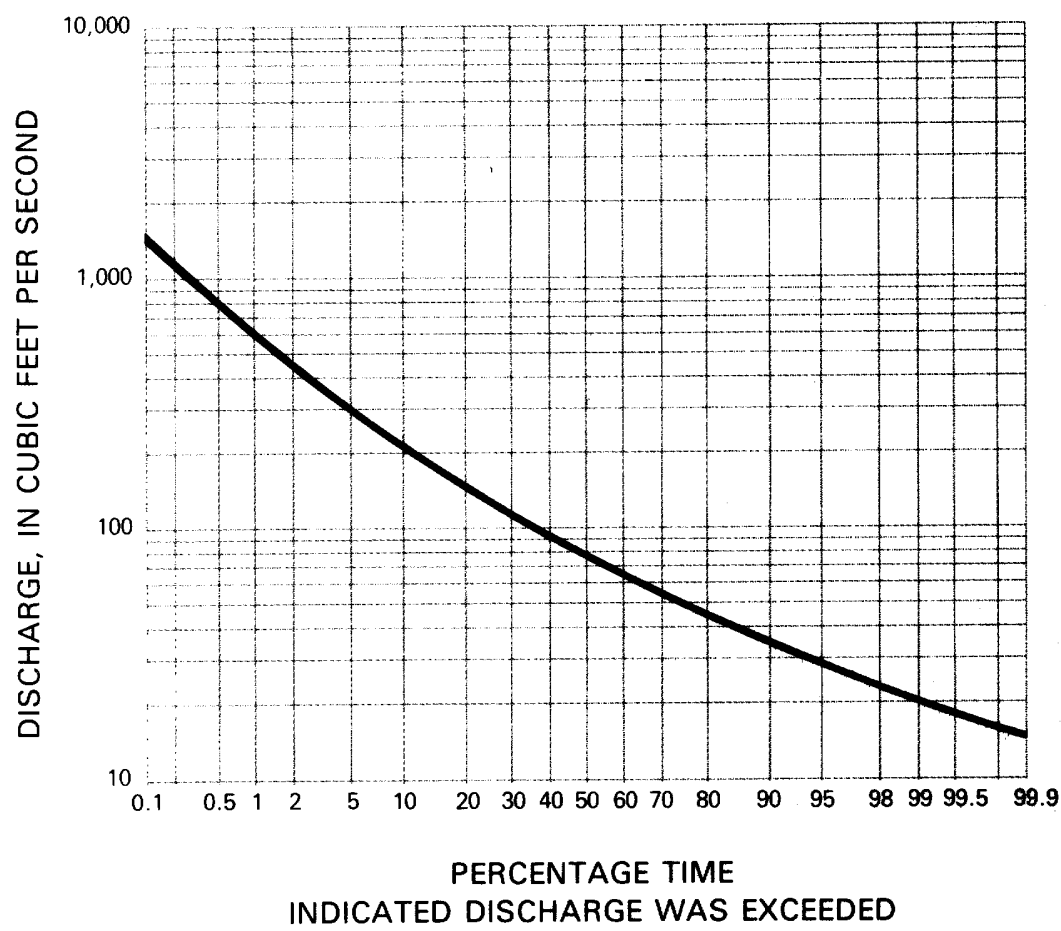



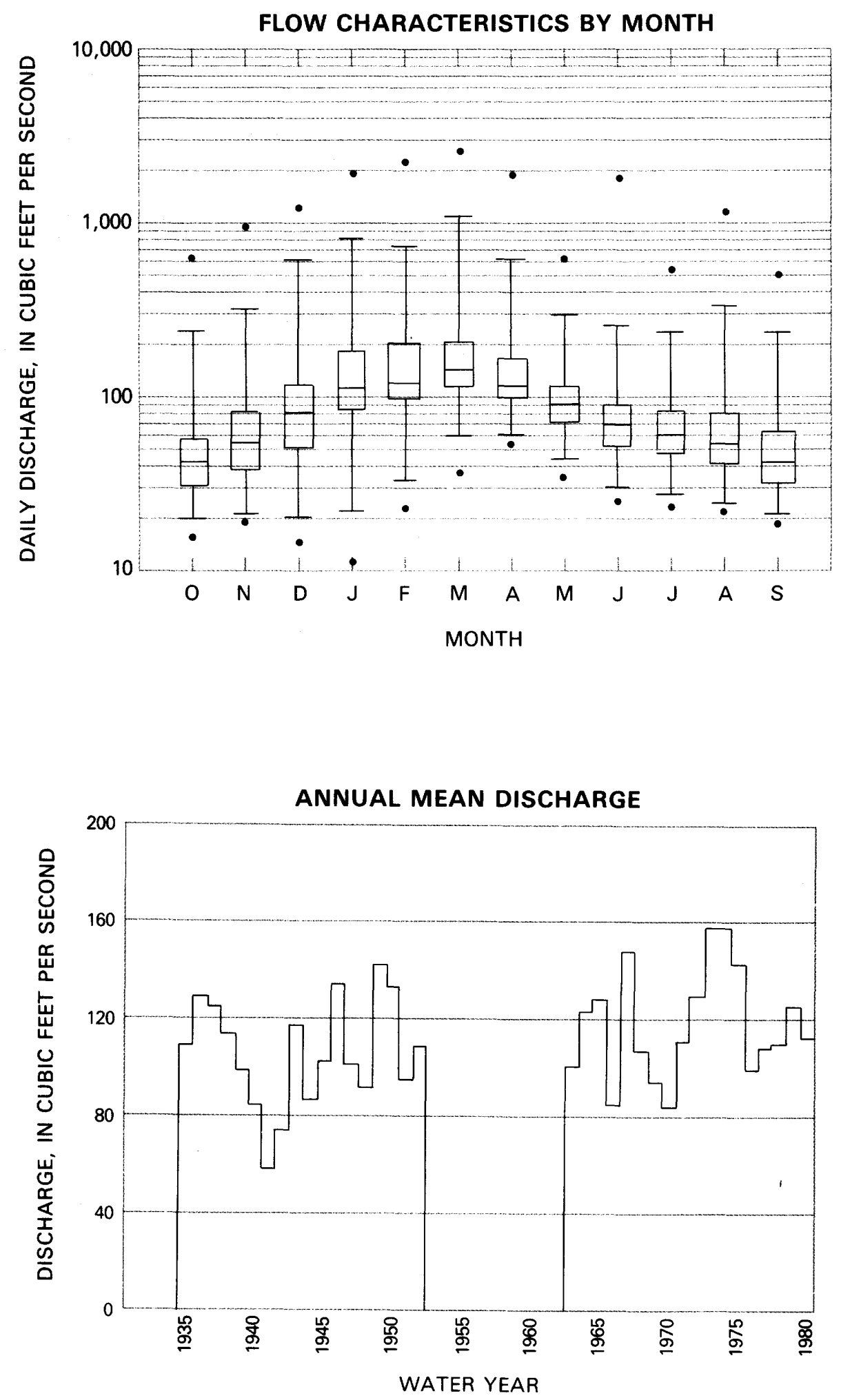
Station 36. - Bear Den Creek near Mandaree, ND (06332515)

Location: Lat $47^{\circ} 47^{\prime} 14^{\prime \prime}$, long $102^{\circ} 46^{\prime} 05^{\prime \prime}$, McKenzie County, 5.5 mi northwest of Mandaree.

Drainage area: $74 \mathrm{mi}^{2}$.

Topography: Most of the basin has rather steep land slopes. The upper part of the basin has gently rolling land surfaces. Basin elevations range from 1,950 to $2,850 \mathrm{ft}$. The divide elevation is generally between 2,400 and $2,700 \mathrm{ft}$.

Rock type: Generally thin interbedded layers of sandy silt, sandstone, silt and clay, and lignite.

Vegetation: About 80 percent of the basin is covered with fairly dense sod formed by native grasses. Small trees occur in coulees and shelter belts. A small part of the basin is used for cultivation of grains.

Manmade influences: The eastern two-thirds of the basin is used for cattle grazing. Cultivation in the western part of the basin covers approximately 20 percent of the total drainage basin. There are about 10 impoundments for stock water. Very few roads are in the area. About 15 oil wells are located in the northwest corner of the basin. About onefourth of the basin is in the Fort Berthold Indian Reservation.

Period of record: June 1966 to September 1980.

Average discharge: $8.8 \mathrm{ft}^{3} / \mathrm{s}$.

Extremes: Maximum discharge, 2,840 ft $3 / \mathrm{s}$, March 13, 1972, gage height, $9.02 \mathrm{ft}$; maximum gage height, $10.03 \mathrm{ft}$, April 6,$1969 ;$ no flow at times most years.

Serial correlation coefficient for annual mean discharges: -0.035 .

Kendall's tau correlation coefficient for annual mean discharges: 0.011 .

FLOW DURATION

\begin{tabular}{|c|rrrr|}
\hline \multicolumn{5}{|c|}{ FLOOD FREQUENCY } \\
\hline \multicolumn{4}{|c|}{ Peak discharge, in cubic feet per second, for } \\
indicated recurrence interval, in years \\
\hline $\begin{array}{c}\text { R. I. } \\
\text { Discharge }\end{array}$ & 2 & 5 & 10 & 25 \\
\hline
\end{tabular}

Standard Deviation (logs): 0.438

Skewness Coefficient (logs): -0.595

\begin{tabular}{|c|c|c|c|c|}
\hline \multicolumn{5}{|c|}{ LOW-FLOW FREQUENCY } \\
\hline $\begin{array}{l}\text { Consecutive } \\
\text { day period }\end{array}$ & \multicolumn{4}{|c|}{$\begin{array}{l}\text { Discharge, in cubic feet per second for } \\
\text { indicated recurrence interval, in years }\end{array}$} \\
\hline & 2 & 5 & 10 & 20 \\
\hline $\begin{array}{r}7 \\
14 \\
30 \\
60 \\
90\end{array}$ & \multicolumn{4}{|c|}{$\begin{array}{l}\text { Long periods of no } \\
\text { flow for most years. }\end{array}$} \\
\hline
\end{tabular}

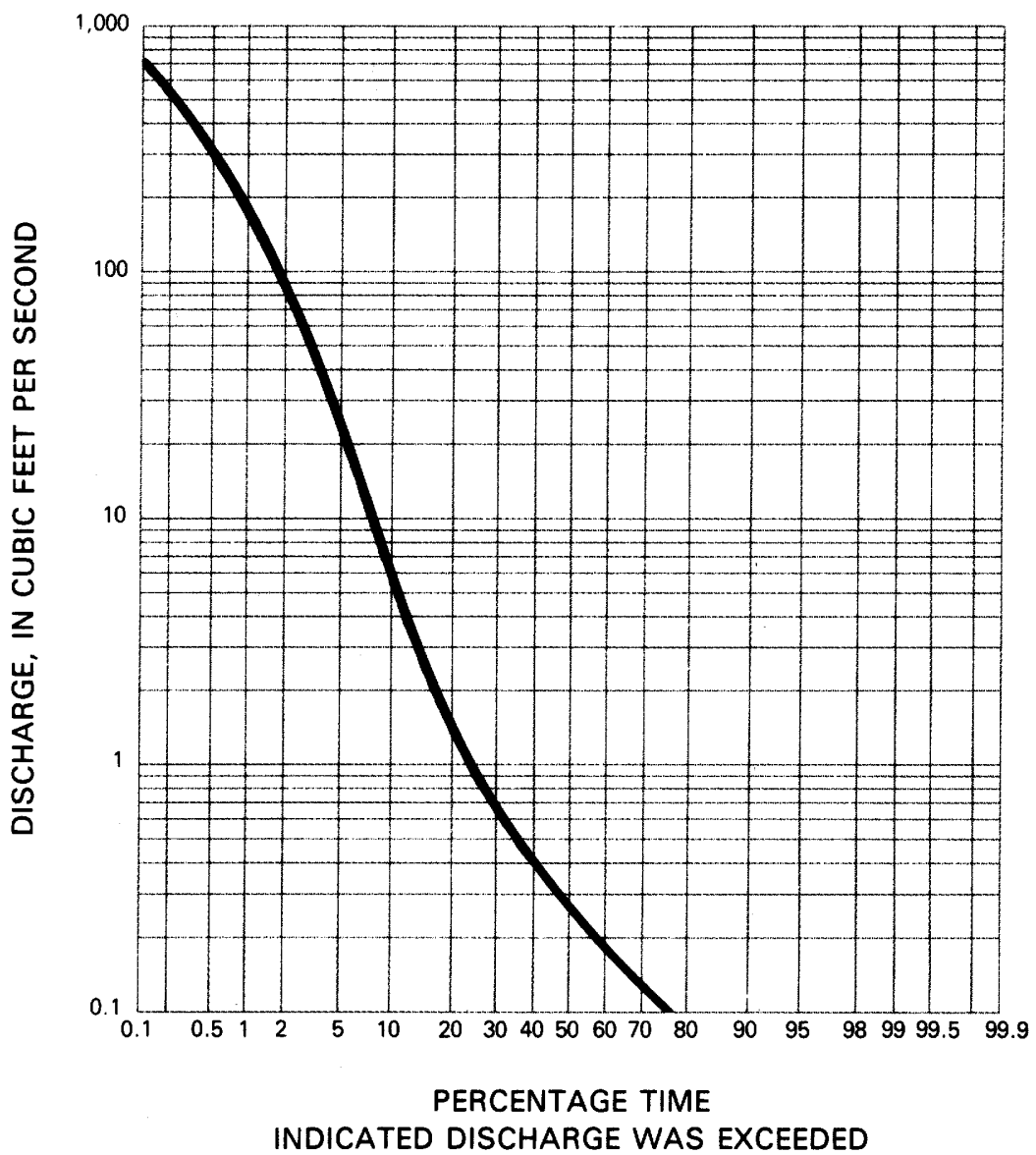



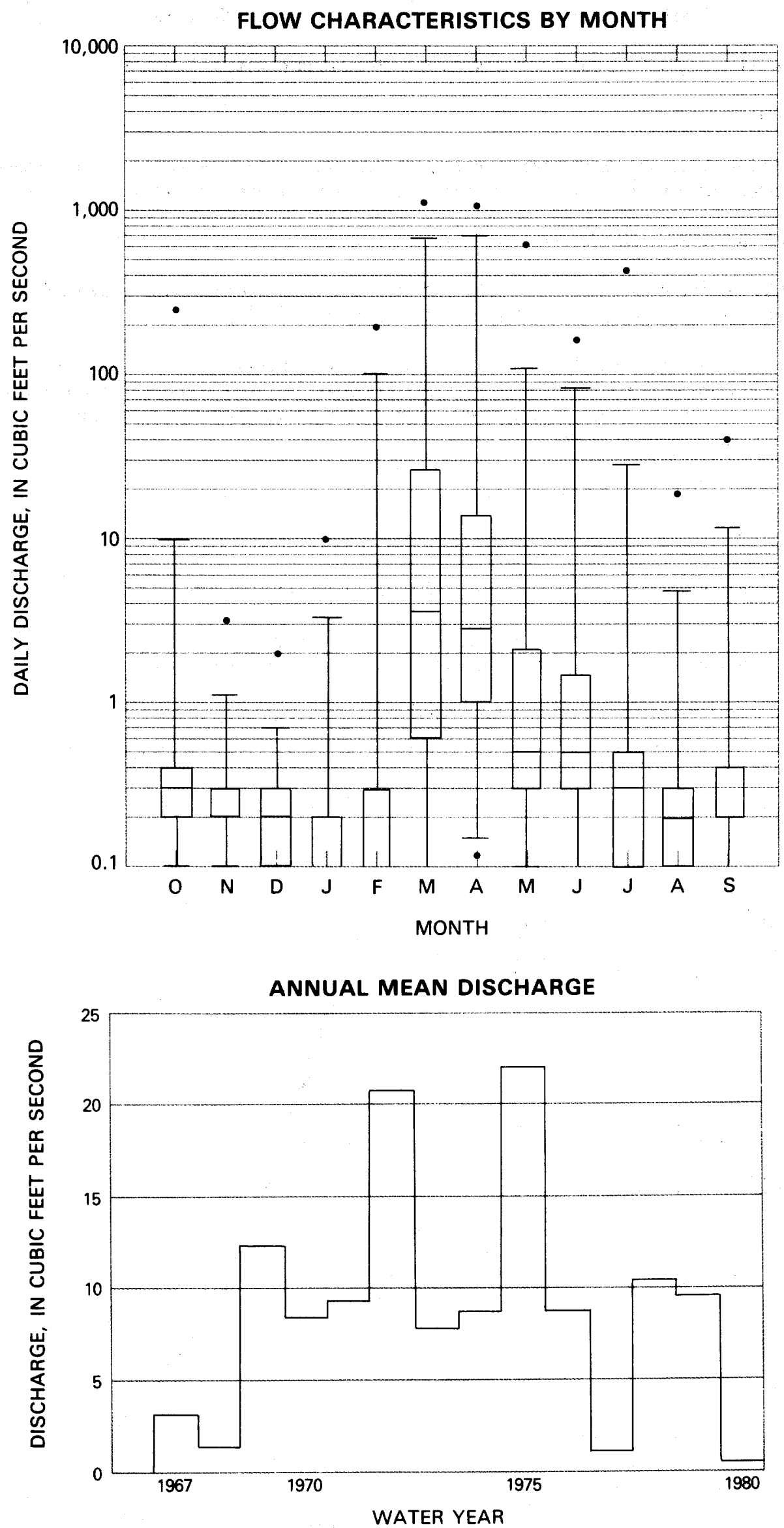
Station 37. - Beaver Creek near Finley, ND (05064900)

Location: Lat $47^{\circ} 35^{\prime} 40^{\prime \prime}$, long $97^{\circ} 42^{\prime} 18^{\prime \prime}$, Steele County, 7 mi northeast of Finley.

Drainage area: $160 \mathrm{mi}^{2}$, approximately.

Topography: Flat to gently rolling terrain. Basin elevations range from 1,170 to $1,520 \mathrm{ft}$. The slope of the main stream is about $15 \mathrm{ft} / \mathrm{mi}$.

Rock type: Clay-rich glacial till covers the shale bedrock to a depth of from 50 to $150 \mathrm{ft}$ in nearly all parts of the basin. Soils are generally very limey loam or clay loam.

Vegetation: Most of the land is under cultivation and small grain crops predominate. Other crops such as corn and potatoes are also raised in the basin. Trees are generally limited to groves around farmsteads and windbreaks along some of the fields. The natural cover is a moderately dense growth of prairie grass.

Manmade influences: Most of the basin is under cultivation. There are several roads. A few stock-water impoundments and a few gravel or borrow pits are in the basin.

Period of record: October 1964 to September 1980.

Average discharge: $9.7 \mathrm{ft}^{3} / \mathrm{s}$.

Extremes: Maximum discharge, 1,900 ft $3 / \mathrm{s}$, April 19, 1979, gage height, $8.35 \mathrm{ft}$, backwater from ice; maximum gage height, $9.70 \mathrm{ft}$, March 14, 1966, backwater from ice; no flow for several months each year.

Serial correlation coefficient for annual mean discharges: -0.316 .

Kendall's tau correlation coefficient for annual mean discharges: -0.167 .

FLOW DURATION

\begin{tabular}{|c|rrrr|}
\hline \multicolumn{5}{|c|}{ FLOOD FREQUENCY } \\
\hline \multicolumn{4}{|c|}{ Peak discharge, in cubic feet per second, for } \\
indicated recurrence interval, in years \\
\hline $\begin{array}{c}\text { R. I. } \\
\text { Discharge }\end{array}$ & 2 & 5 & 10 & 25 \\
\hline
\end{tabular}

Standard Deviation (logs): 0.528

Skewness Coefficient (logs): $\mathbf{- 0 . 6 2 8}$

\begin{tabular}{|c|c|c|c|c|}
\hline \multicolumn{5}{|c|}{ LOW-FLOW FREQUENCY } \\
\hline $\begin{array}{l}\text { Consecutive } \\
\text { day period }\end{array}$ & \multicolumn{4}{|c|}{$\begin{array}{l}\text { Discharge, in cubic feet per second for } \\
\text { indicated recurrence interval, in years }\end{array}$} \\
\hline & 2 & 5 & 10 & 20 \\
\hline $\begin{array}{r}7 \\
14 \\
30 \\
60 \\
90\end{array}$ & & \multicolumn{3}{|c|}{$\begin{array}{l}\text { Long periods of no } \\
\text { flow for all years. }\end{array}$} \\
\hline
\end{tabular}
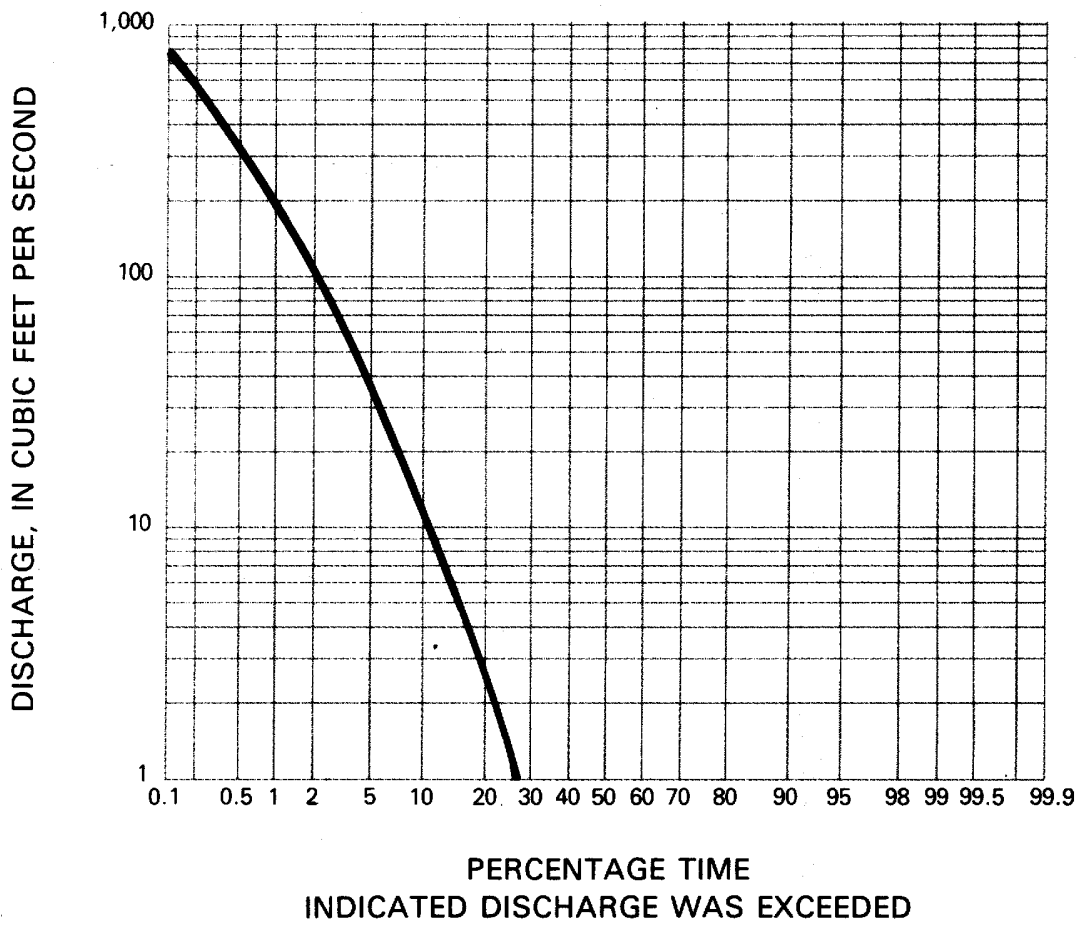

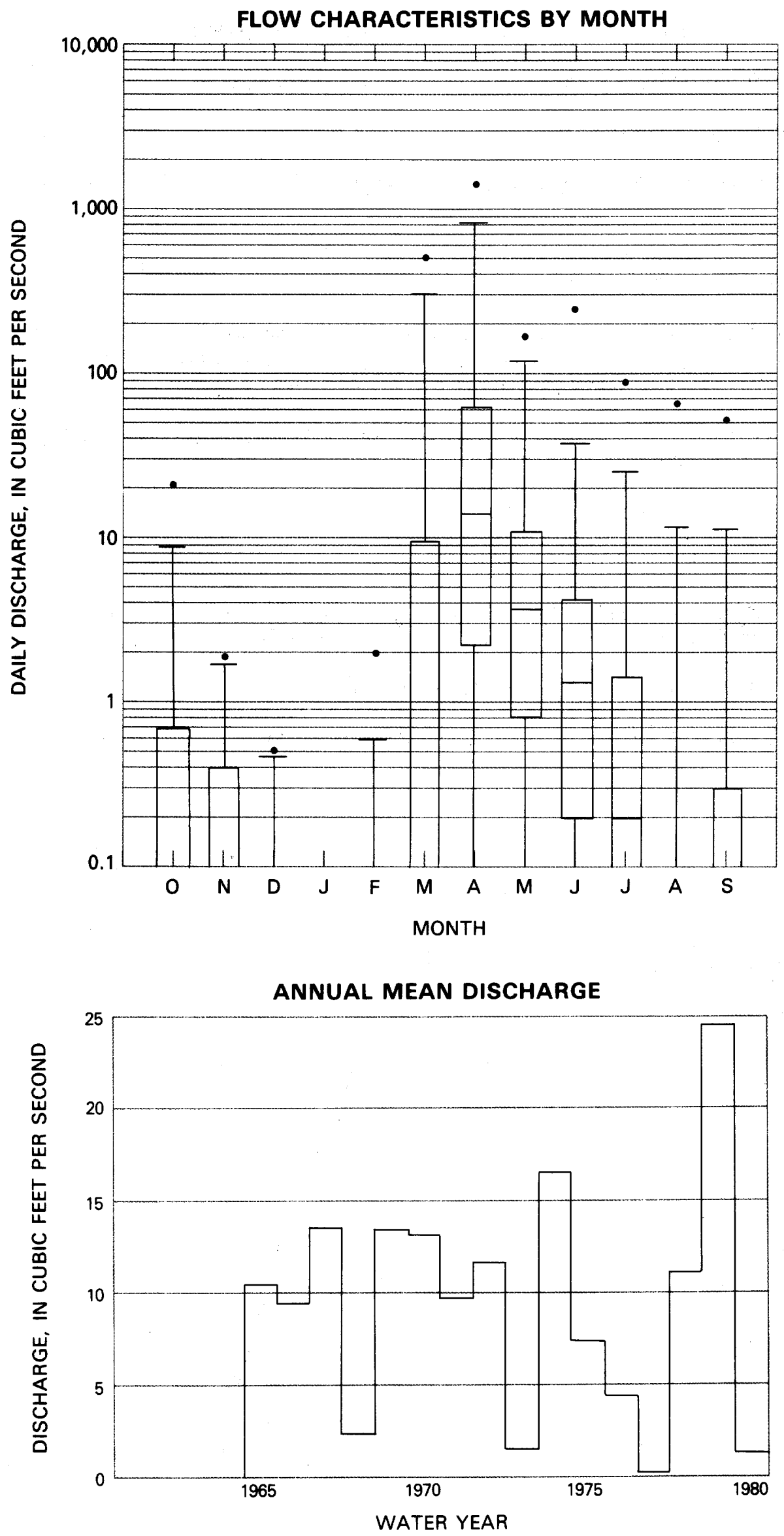
Station 38.-Upper Twin Creek at McGaw, $\mathrm{OH}$ (03237280)

Location: Lat $38^{\circ} 38^{\prime} 37^{\prime \prime}$, long $83^{\circ} 12^{\prime} 57^{\prime \prime}$, Scioto County, 0.7 mi upstream from bridge on U.S. Highway 52 at McGaw and 2.7 mi northeast of Buena Vista. Prior to July 21, 1972, at site 0.7 mi downstream.

Drainage area: $12.2 \mathrm{mi}^{2}$.

Topography: Except for a narrow floodplain, the general land surface is extremely hilly. Basin elevations range from 520 to $1,290 \mathrm{ft}$. The slope of the main stream is about $58 \mathrm{ft} / \mathrm{mi}$.

Rock type: Shales and sandstones outcrop in the basin. Soils are very thin. Valley fill consists of rock and gravel deposits.

Vegetation: The basin generally is covered with a dense second-growth hardwood forest. There are some cultivated lands on the narrow floodplain and on a few scattered farms.

Manmade influences: About 90 percent of the basin is in State Forest land, the remainder being privately owned. Logging practices have been principally on the privately owned land. A few scattered farms and summer cottages are in the basin. One road follows the stream valley. Gravel is removed from the streambed at one site.

Period of record: June 1963 to September 1980.

Average discharge: $14.4 \mathrm{ft}^{3} / \mathrm{s}$.

Extremes: Maximum discharge, 3,500 ft ${ }^{3} / \mathrm{s}$, March 4, 1964, gage height, $9.7 \mathrm{ft}$, in gage well, $10.2 \mathrm{ft}$, from outside highwater mark, from rating curve extended above $300 \mathrm{ft}^{3} / \mathrm{s}$ on basis of slope-area measurement of peak flow; no flow for many days most years.

Serial correlation coefficient for annual mean discharges: 0.239 .

Kendall's tau correlation coefficient for annual mean discharges: 0.338 .

\begin{tabular}{|c|rrrr|}
\hline \multicolumn{5}{|c|}{ FLOOD FREQUENCY } \\
\hline \multicolumn{4}{|c|}{$\begin{array}{c}\text { Peak discharge, in cubic feet per second, for } \\
\text { indicated recurrence interval, in years }\end{array}$} \\
\hline R. I. & 2 & 5 & 10 & 25 \\
Discharge & 970 & 1,800 & 2,420 & 3,260 \\
\hline
\end{tabular}

Standard Deviation (logs): 0.337

Skewness Coefficient (logs): -0.362

\begin{tabular}{|c|cccc|}
\hline \multicolumn{5}{|c|}{ LOW-FLOW FREQUENCY } \\
\hline $\begin{array}{c}\text { Consecutive } \\
\text { day period }\end{array}$ & \multicolumn{3}{|c|}{$\begin{array}{l}\text { Discharge, in cubic feet per second for } \\
\text { indicated recurrence interval, in years }\end{array}$} \\
\hline & 2 & 5 & 10 & 20 \\
\cline { 2 - 5 } & 0.1 & 0 & 0 & 0 \\
7 & 0.1 & 0 & 0 & 0 \\
30 & 0.2 & 0 & 0 & 0 \\
60 & 0.5 & 0.1 & 0.1 & 0 \\
90 & 0.9 & 0.3 & 0.1 & 0.1 \\
\hline
\end{tabular}

FLOW DURATION

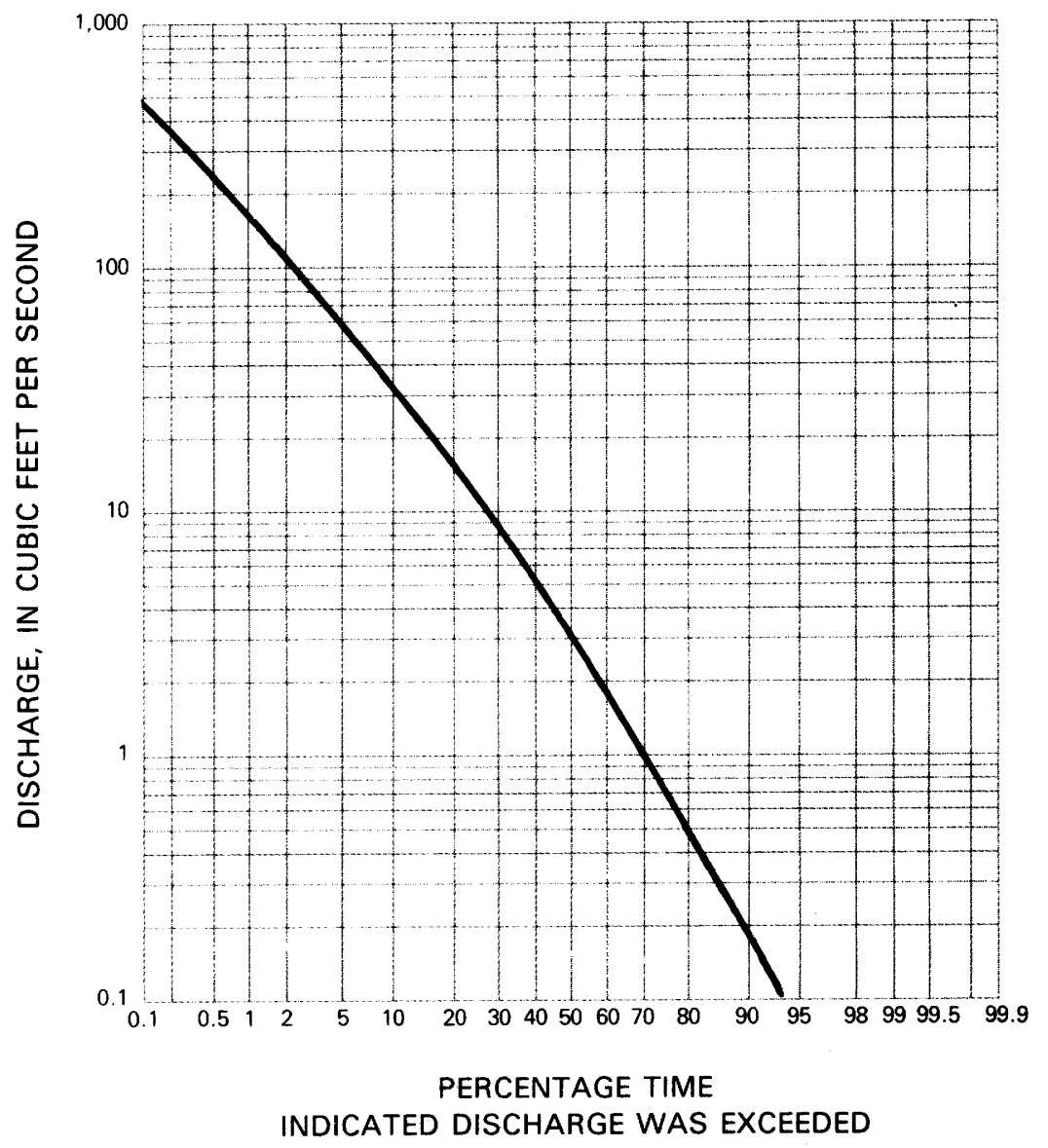



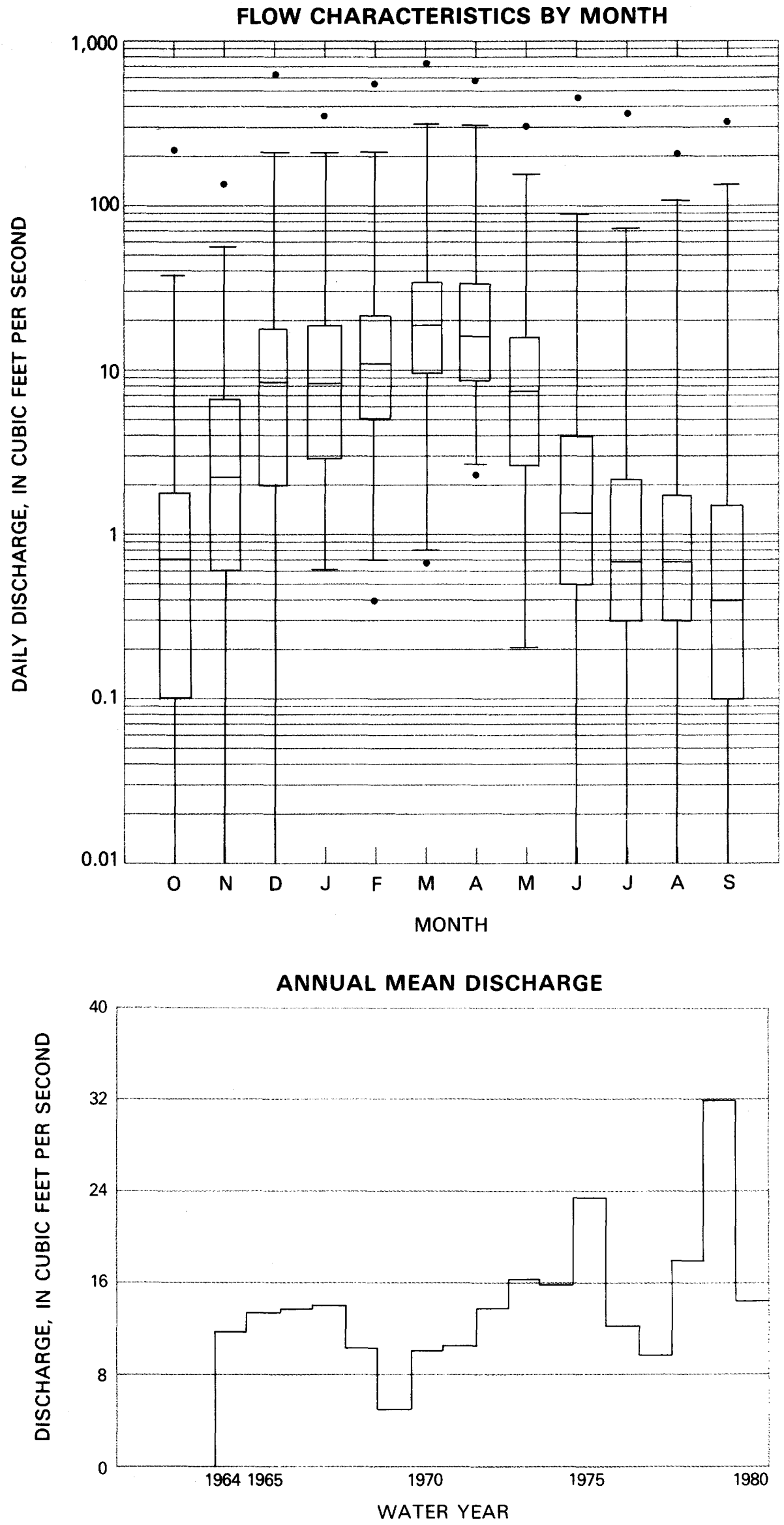
Station 39. - Blue Beaver Creek near Cache, OK (07311200)

Location: Lat $34^{\circ} 37^{\prime} 24^{\prime \prime}$, long $98^{\circ} 33^{\prime} 48^{\prime \prime}$, Comanche County, 4 mi east of Cache.

Drainage area: $24.6 \mathrm{mi}^{2}$.

Topography: Most of the basin is composed of numerous low granite mountains and narrow valleys. Undulating plains form the lower part of the watershed. Basin elevations range from 1,210 to $2,400 \mathrm{ft}$; the elevation of a mean basin divide is about 1,900 ft. The slope of the main stream is about $60 \mathrm{ft} / \mathrm{mi}$ in the mountains and about $25 \mathrm{ft} / \mathrm{mi}$ on the plains.

Rock type: Crystalline rocks, principally granite, underlie the basin. Gabbro and rhyolite are also found in the basin. These rocks are fractured and show exfoliation effects. Large boulder fields cover parts of the basin. Areas of bare rock and boulder fields having no vegetation cover small parts of the drainage.

Vegetation: Most of the watershed is covered with native grass. The basin also contains scattered areas of mostly blackjack and post oak.

Manmade influences: Most of the basin is in the Wichita Mountain Wildlife Refuge or the Fort Sill Military Reservation, which is used for artillery practice. Some roads cross the basin. The main stream contains three small reservoirs having a combined surface area of 130 acres. Evaporation losses are expected to affect the average natural runoff by 10 to 15 percent. Low flows will be most seriously affected.

Period of record: July 1964 to September 1980.

Average discharge: $8.99 \mathrm{ft}^{3} / \mathrm{s}$.

Extremes: Maximum discharge, 13,600 ft $\mathrm{t}^{3} / \mathrm{s}$, August 28, 1977, gage height, $18.02 \mathrm{ft}$ from floodmarks, from rating curve extended above $1,250 \mathrm{ft}^{3} / \mathrm{s}$ on basis of two contracted opening measurements and step-backwater analysis; no flow at times each year.

Serial correlation coefficient for annual mean discharges: 0.033 .

Kendall's tau correlation coefficient for annual mean discharges: 0.217.

\begin{tabular}{|c|rrrr|}
\hline \multicolumn{4}{|c|}{ FLOOD FREQUENCY } \\
\hline \multicolumn{4}{|c|}{ Peak discharge, in cubic feet per second, for } \\
indicated recurrence interval, in years \\
\hline $\begin{array}{c}\text { R. I. } \\
\text { Discharge }\end{array}$ & 2 & 5 & 10 & 25 \\
1,220 & 2,970 & 4,650 & 7,420 \\
\hline
\end{tabular}

Standard Deviation (logs): 0.468

Skewness Coefficient (logs): -0.153

\begin{tabular}{|c|c|c|c|c|}
\hline \multicolumn{5}{|c|}{ LOW-FLOW FREQUENCY } \\
\hline $\begin{array}{l}\text { Consecutive } \\
\text { day period }\end{array}$ & \multicolumn{4}{|c|}{$\begin{array}{l}\text { Discharge, in cubic feet per second for } \\
\text { indicated recurrence interval, in years }\end{array}$} \\
\hline & 2 & 5 & 10 & 20 \\
\hline $\begin{array}{r}7 \\
14 \\
30 \\
60 \\
90\end{array}$ & & \multicolumn{3}{|c|}{$\begin{array}{l}\text { Long periods of no } \\
\text { flow for most years. }\end{array}$} \\
\hline
\end{tabular}

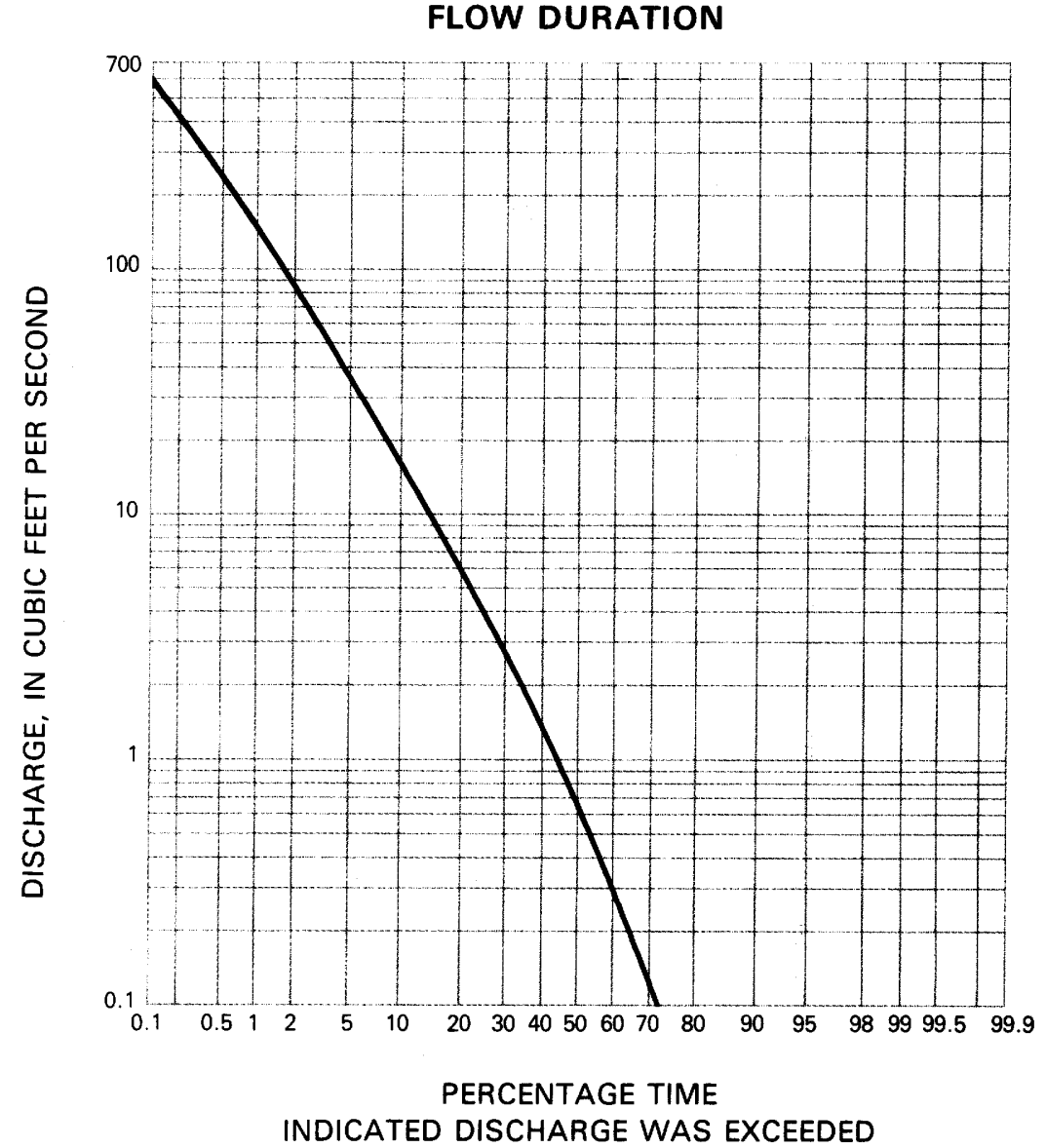



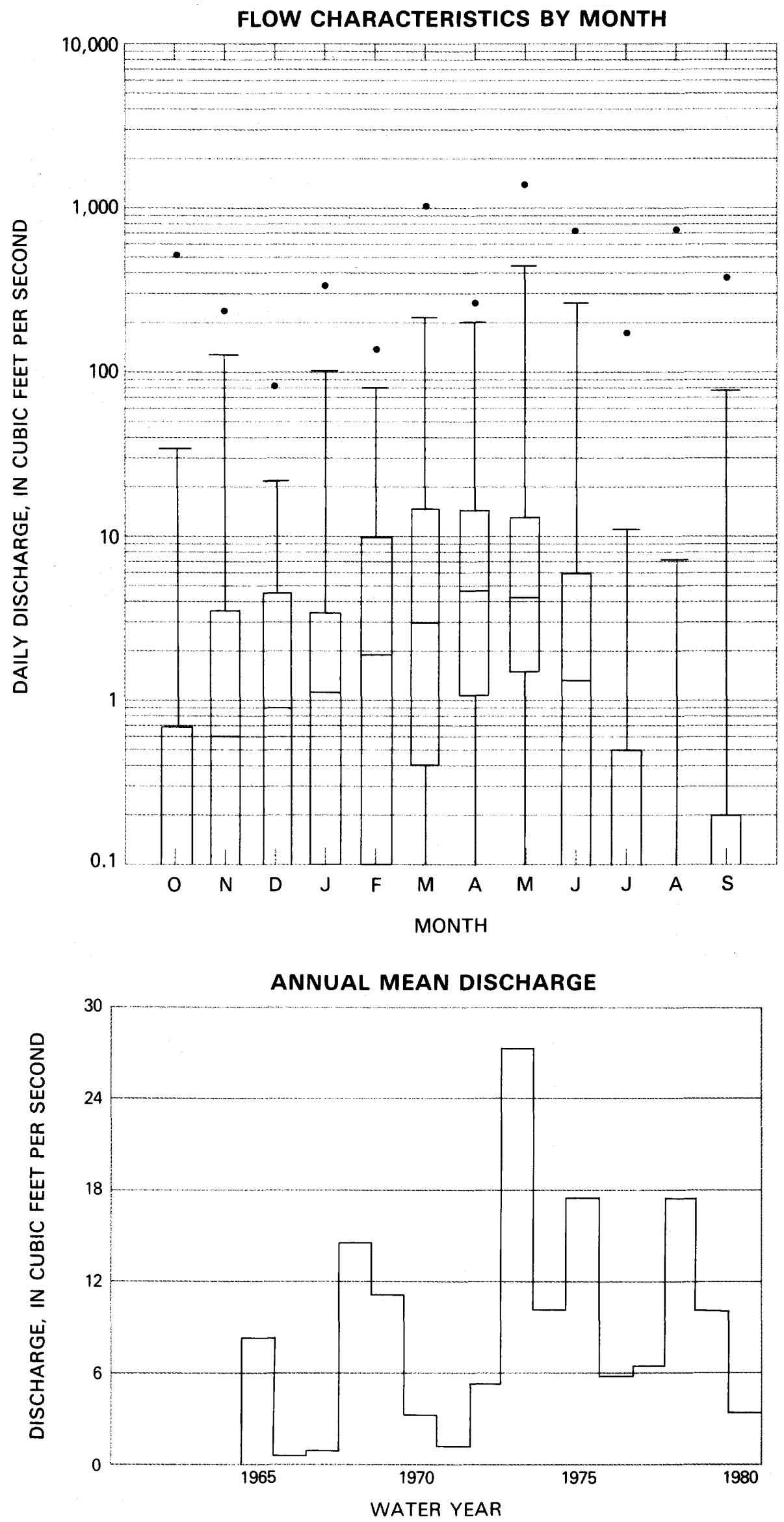
Location: Lat $34^{\circ} 38^{\prime} 18^{\prime \prime}$, long $94^{\circ} 36^{\prime} 45^{\prime \prime}$, LeFlore County, 2.1 mi east of Big Cedar.

Drainage area: $40.1 \mathrm{mi}^{2}$.

Topography: The general surface of the land consists of a half-mile-wide valley between parallel mountain ridges. Basin elevations range from 890 to $2,660 \mathrm{ft}$. The main stream slope is about $60 \mathrm{ft} / \mathrm{mi}$.

Rock type: The underlying formation consists of dark slaty shale, siliceous beds, and well-cemented dark sandstones. The rocks are strongly folded and faulted.

Vegetation: Except for a few square miles of grassland in the valley, the area is covered with pine and hardwood forest of moderate density.

Manmade influences: The entire basin lies within the Ouachita National Forest. A small amount of logging is practiced. Farming in the basin consists of raising cattle and pigs, and corn is grown in a few small plots. Some roads traverse the basin.

Period of record: October 1965 to September 1980.

Average discharge: $74.6 \mathrm{ft}^{3} / \mathrm{s}$.

Extremes: Maximum discharge, 21,500 ft $3 / \mathrm{s}$, December 10, 1971, gage height, $17.08 \mathrm{ft}$, from rating curve extended above $9,000 \mathrm{ft}^{3} / \mathrm{s}$; no flow at times in most years.

Serial correlation coefficient for annual mean discharges: -0.155 .

Kendall's tau correlation coefficient for annual mean discharges: -0.048 .

\begin{tabular}{|c|rrrr|}
\hline \multicolumn{5}{|c|}{ FLOOD FREQUENCY } \\
\hline \multicolumn{4}{|c|}{$\begin{array}{c}\text { Peak discharge, in cubic feet per second, for } \\
\text { indicated recurrence interval, in years }\end{array}$} \\
\hline $\begin{array}{c}\text { R. I. } \\
\text { Discharge }\end{array}$ & 2 & 5 & 10 & 25 \\
\hline
\end{tabular}

Standard Deviation (logs): 0.233

Skewness Coefficient (logs): -0.292

\begin{tabular}{|c|cccc|}
\hline \multicolumn{5}{|c|}{ LOW-FLOW FREQUENCY } \\
\hline $\begin{array}{c}\text { Consecutive } \\
\text { day period }\end{array}$ & \multicolumn{3}{|c|}{$\begin{array}{l}\text { Discharge, in cubic feet per second for } \\
\text { indicated recurrence interval, in years }\end{array}$} \\
\hline & 2 & 5 & 10 & 20 \\
\cline { 2 - 5 } 7 & 0.1 & 0 & 0 & 0 \\
14 & 0.2 & 0 & 0 & 0 \\
30 & 0.3 & 0 & 0 & 0 \\
60 & 0.5 & 0.1 & 0 & 0 \\
90 & 2.3 & 0.2 & 0 & 0 \\
\hline
\end{tabular}

\section{FLOW DURATION}

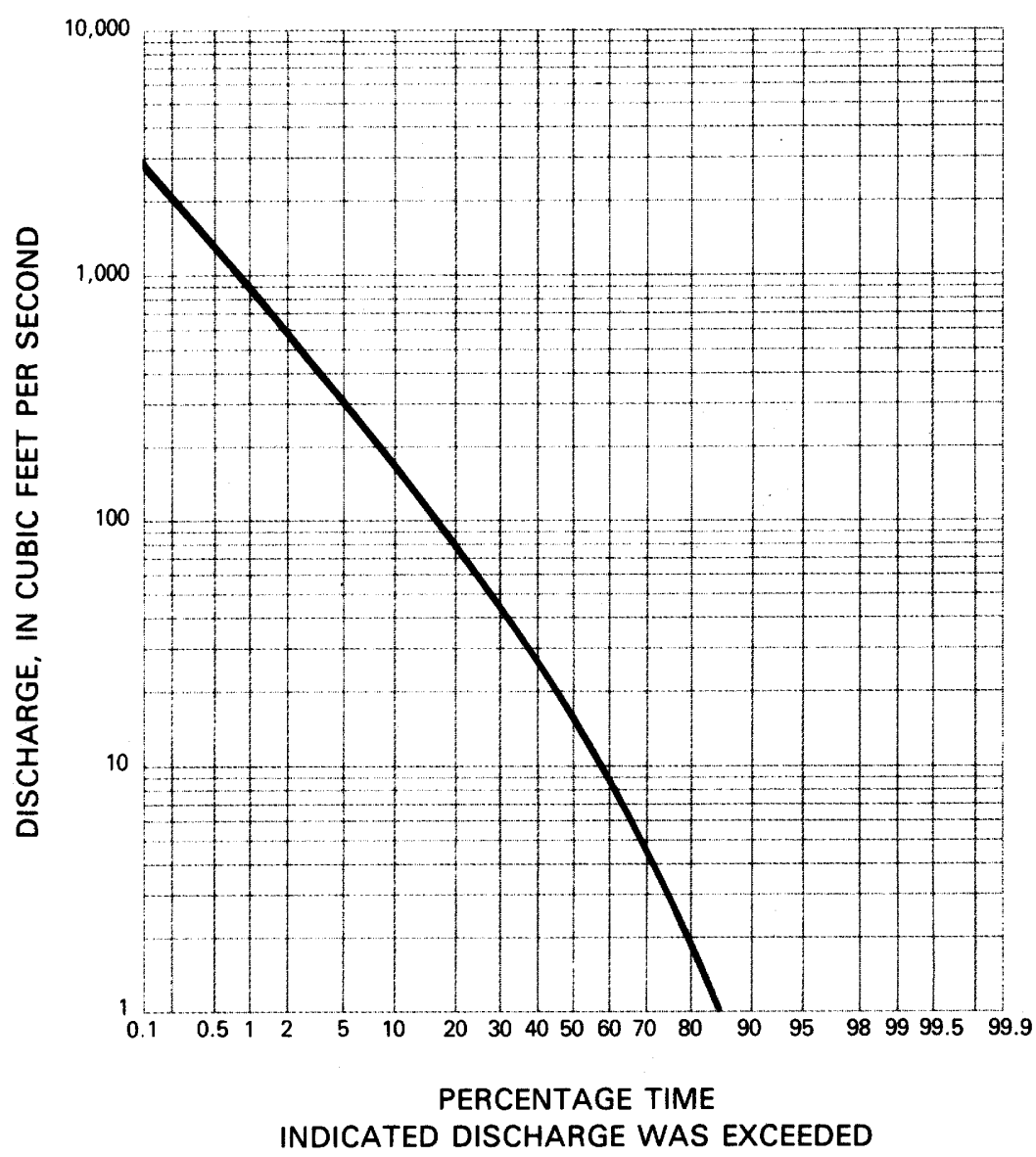



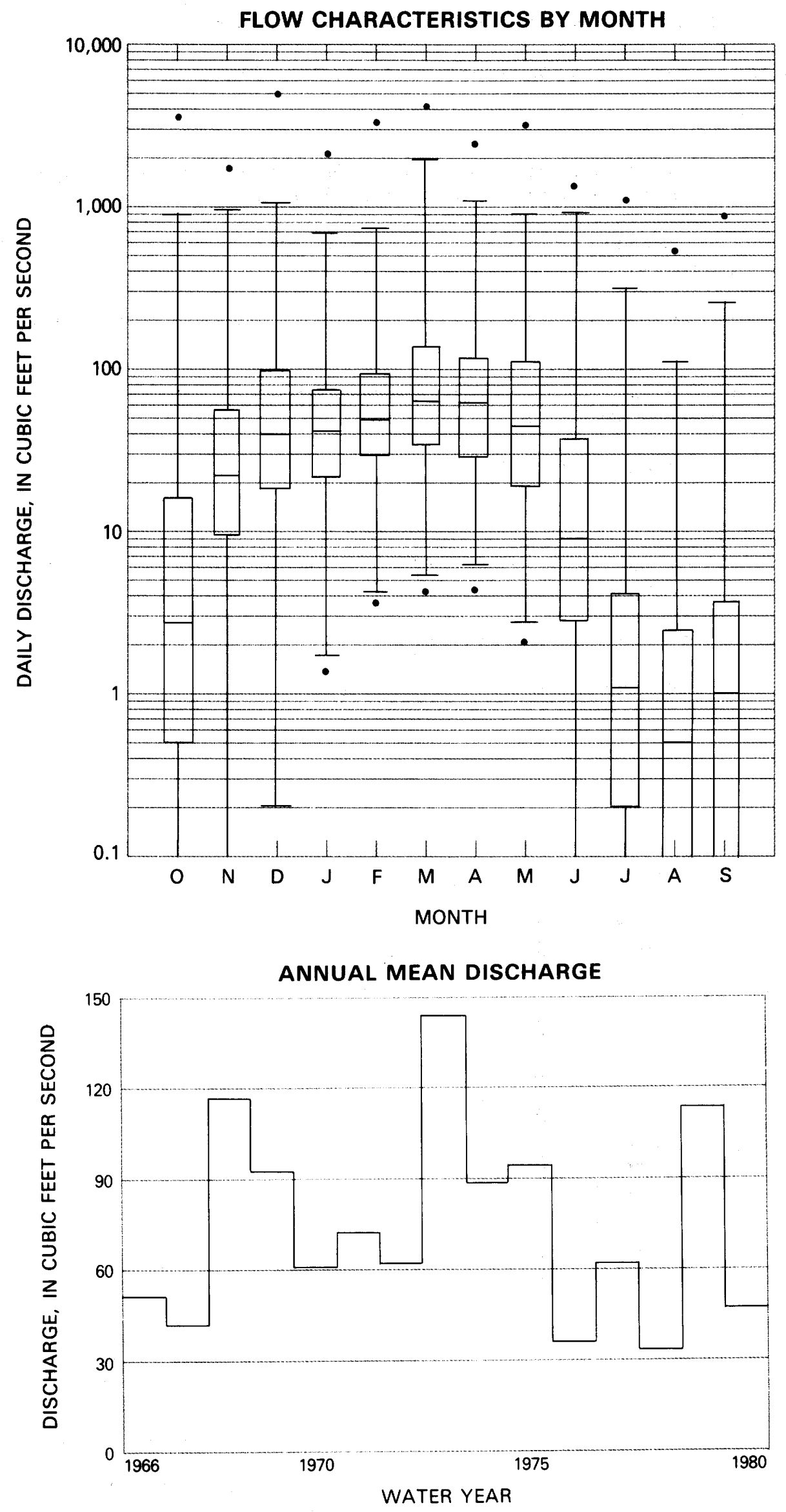
Station 41. - Crater Lake near Crater Lake, OR (11492200)

Location: Lat $42^{\circ} 58^{\prime} 45^{\prime \prime}$, long $122^{\circ} 04^{\prime} 45^{\prime \prime}$, Klamath County, at boat harbor in Cleetwood Cove in Crater Lake National Park, 6 mi northeast of Crater Lake post office.

Drainage area: $26.2 \mathrm{mi}^{2}$, of which $20.5 \mathrm{mi}^{2}$ is lake area at elevation $6,176 \mathrm{ft}$.

Topography: Crater Lake occupies the caldera of prehistoric Mount Mazama. The elevation of the crater rim ranges from 6,650 to $8,160 \mathrm{ft}$, and the lake elevation is about $6,170 \mathrm{ft}$. The walls of the crater are generally very steep.

Rock type: The entire area is underlain by volcanic rocks. The principal types are andesitic lava, basaltic lava, and pumiceous volcanic-flow breccias and tuffs, largely of andesitic composition.

Vegetation: The land area is sparsely covered with various types of pine.

Manmade influences: The basin is entirely within Crater Lake National Park. A highway circles the lake. Most human activity and facilities related to the lake as a scenic attraction are outside the basin.

Period of record: October 1961 to September 1980; fragmentary records available 1878-1961.

Extremes: Maximum observed elevation 6,179.34 ft, March 25, 1975; maximum elevation known, 6, 180.5 ft (date unknown), based on several observations of line of crustose lichens; minimum observed, 6,163.2 ft, September 10, 1942. 
HIGHEST AND LOWEST LEVEL OF CRATER LAKE, OREGON

(observed each year during period of continuous record)

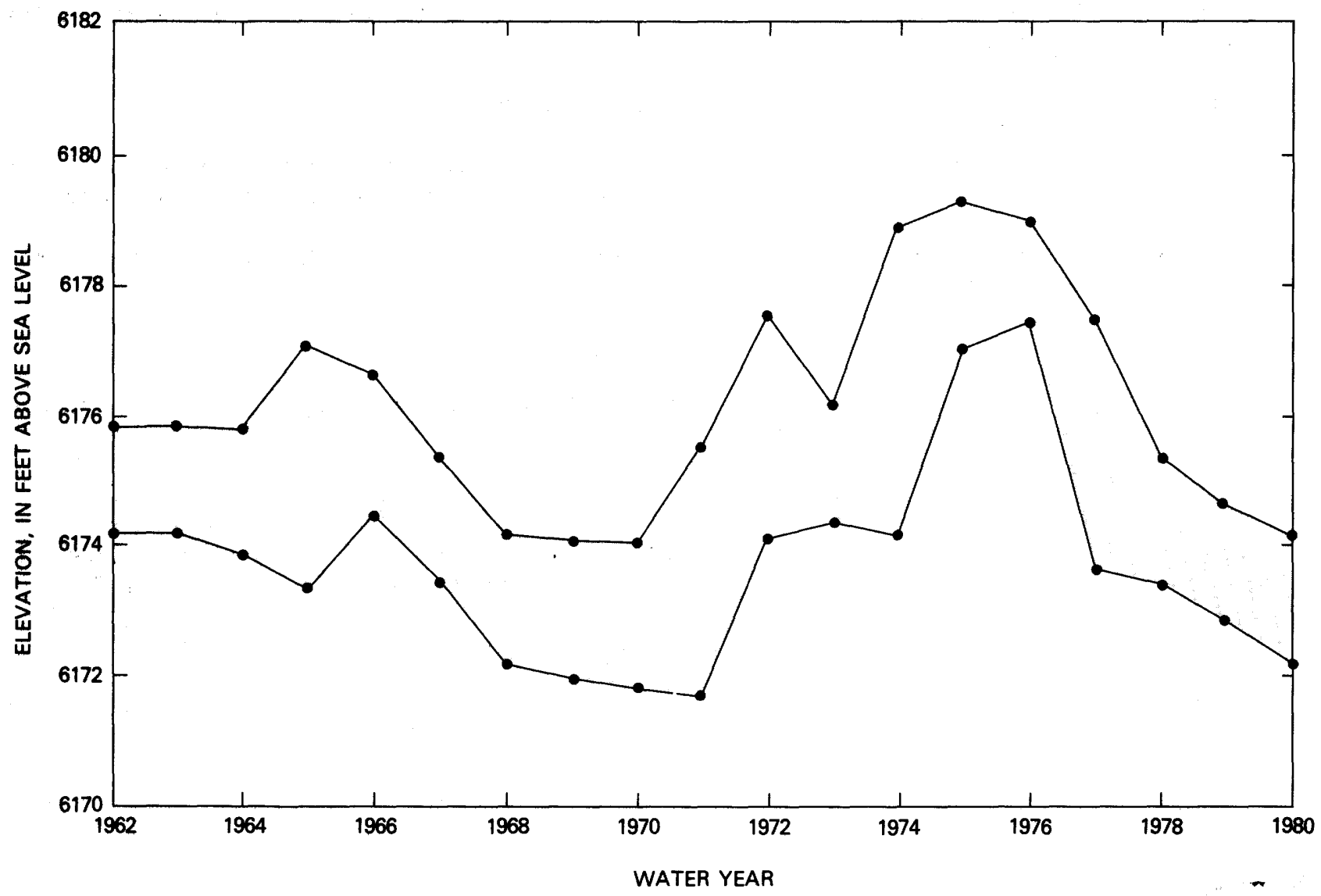


Station 42. - Minam River at Minam, OR (13331500)

Location: Lat $45^{\circ} 37^{\prime} 12^{\prime \prime}$, long $117^{\circ} 43^{\prime} 32^{\prime \prime}$, Wallowa County, 0.3 mi west of Minam.

Drainage area: $240 \mathrm{mi}^{2}$, approximately.

Topography: Complex mountains and dissected volcanic plateaus. Several small lakes occur in the headwaters of the basin. The total surface area of these lakes is about 200 acres. Basin elevations range from 2,540 to about $8,900 \mathrm{ft}$. The slope of the main stream is about $65 \mathrm{ft} / \mathrm{mi}$.

Rock type: Predominantly basalt.

Vegetation: Ponderosa pine is the predominant species in the area to an elevation of 5,500 ft. Above 5,500 ft the forest changes to a mixture of ponderosa pine, lodgepole pine, white fir, and western larch.

Manmade influences: Most of the basin is managed by the U.S. Forest Service as a primitive area. Some sheep and cattle grazing is permitted. There is a private hunting lodge and an airstrip in midbasin. Access by road is limited to the lower $10 \mathrm{mi}$ of the basin.

Period of record: June 1912 to March 1914, September 1965 to September 1980.

Average discharge: $472 \mathrm{ft}^{3} / \mathrm{s}$.

Extremes: Maximum discharge, 6,260 ft ${ }^{3} / \mathrm{s}$, June 16, 1974, gage height, $6.89 \mathrm{ft}$; maximum gage height, $7.3 \mathrm{ft}$, May 28,1913 , datum then in use; minimum discharge, $10 \mathrm{ft}^{3} / \mathrm{s}$, December 6,1972 , January 10,1973 , result of freezeup.

Serial correlation coefficient for annual mean discharges: -0.300 .

Kendall's tau correlation coefficient for annual mean discharges: 0.067 .

\section{FLOW DURATION}

\begin{tabular}{|c|rrrr|}
\hline \multicolumn{5}{|c|}{ FLOOD FREQUENCY } \\
\hline \multicolumn{4}{|c|}{$\begin{array}{l}\text { Peak discharge, in cubic feet per second, for } \\
\text { indicated recurrence interval, in years }\end{array}$} \\
\hline $\begin{array}{r}\text { R. I. } \\
\text { Discharge }\end{array}$ & 2 & 5 & 10 & 25 \\
\hline
\end{tabular}

Standard Deviation (logs): 0.154

Skewness Coefficient (logs): 0.020

\begin{tabular}{|c|cccc|}
\hline \multicolumn{4}{|c|}{ LOW-FLOW FREQUENCY } \\
\hline $\begin{array}{c}\text { Consecutive } \\
\text { day period }\end{array}$ & \multicolumn{3}{|c|}{$\begin{array}{c}\text { Discharge, in cubic feet per second for } \\
\text { indicated recurrence interval, in years }\end{array}$} \\
\hline & 2 & 5 & 10 & 20 \\
\cline { 2 - 5 } 7 & 62 & 41 & 30 & 23 \\
14 & 63 & 47 & 40 & 35 \\
30 & 70 & 57 & 52 & 49 \\
60 & 79 & 63 & 57 & 53 \\
90 & 86 & 67 & 60 & 56 \\
\hline
\end{tabular}

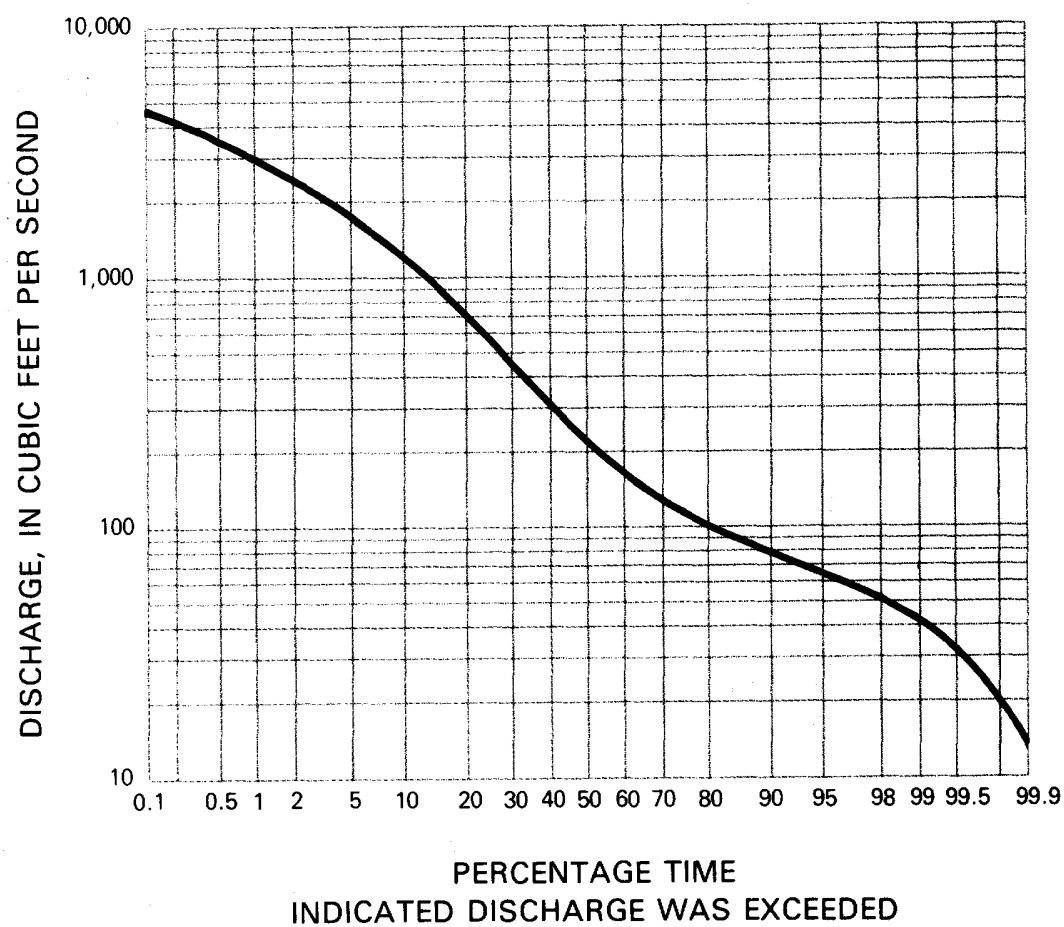



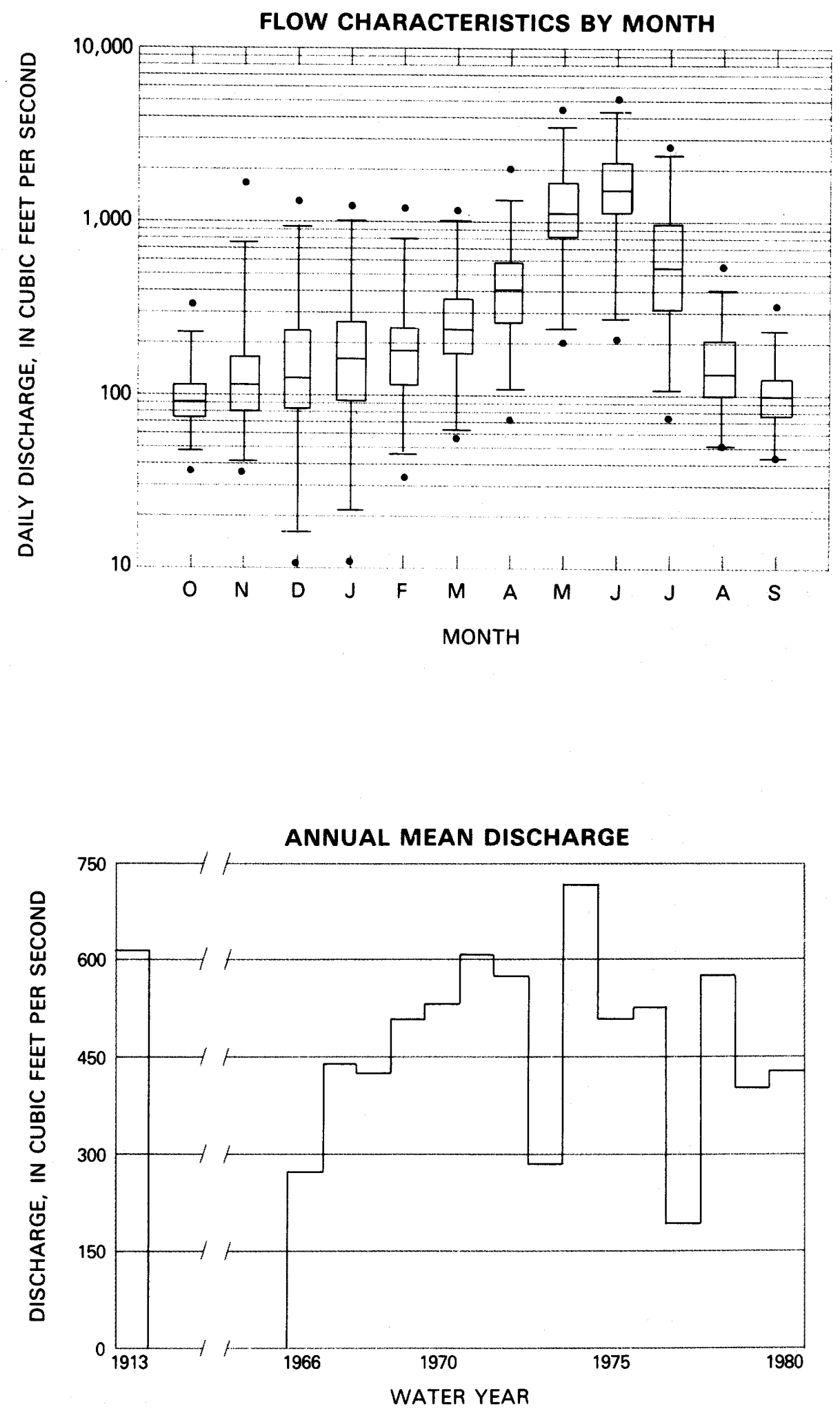
Station 43. - Young Womans Creek near Renovo, PA (01545600)

Location: Lat $41^{\circ} 23^{\prime} 22^{\prime \prime}$, long $77^{\circ} 41^{\prime} 28^{\prime \prime}$, Clinton County, 5 mi northeast of Renovo.

Drainage area: $46.2 \mathrm{mi}^{2}$.

Topography: Broad, flat mountains and narrow, steep-sided valleys. The general elevation of the divide is $1,800 \mathrm{ft}$. Basin elevations range from 780 to $2,180 \mathrm{ft}$. The slope of the main stream is about $100 \mathrm{ft} / \mathrm{mi}$.

Rock type: Predominantly sandstone and shale. Some unconsolidated glacial outwash lines the creek bottom.

Vegetation: The area is covered with northern hardwoods, namely ash, beech, birch, cherry, and maple.

Manmade influences: Two secondary roads and some fire trails traverse the basin.

Period of record: December 1964 to September 1980.

Average discharge: $78.1 \mathrm{ft}^{3} / \mathrm{s}$.

Extremes: Maximum discharge, 5,370 ft ${ }^{3} / \mathrm{s}$, June 23, 1972, gage height, $7.98 \mathrm{ft}$, from rating curve extended above 1,000 $\mathrm{ft}^{3} / \mathrm{s}$ on basis of slope-area measurement of peak flow; minimum, $1.1 \mathrm{ft}^{3} / \mathrm{s}$, September $6,7,1971$; minimum gage height, $1.45 \mathrm{ft}$, August 30, 31, September 1, 1966.

Serial correlation coefficient for annual mean discharges: 0.580 .

Kendall's tau correlation coefficient for annual mean discharges: 0.486 .

\begin{tabular}{|c|rrrr|}
\hline \multicolumn{5}{|c|}{ FLOOD FREQUENCY } \\
\hline \multicolumn{4}{|c|}{$\begin{array}{c}\text { Peak discharge, in cubic feet per second, for } \\
\text { indicated recurrence interval, in years }\end{array}$} \\
\hline $\begin{array}{c}\text { R. I. } \\
\text { Discharge }\end{array}$ & 2 & 5 & 10 & 25 \\
\hline
\end{tabular}

Standard Deviation (logs): 0.307

Skewness Coefficient (logs): 0.603

\begin{tabular}{|c|cccc|}
\hline \multicolumn{4}{|c|}{ LOW-FLOW FREQUENCY } \\
\hline $\begin{array}{l}\text { Consecutive } \\
\text { day period }\end{array}$ & \multicolumn{3}{|c|}{$\begin{array}{l}\text { Discharge, in cubic feet per second for } \\
\text { indicated recurrence interval, in years }\end{array}$} \\
\hline & 2 & 5 & 10 & 20 \\
\cline { 2 - 5 } 7 & 5.0 & 2.8 & 2.0 & 1.5 \\
14 & 5.8 & 3.2 & 2.3 & 1.8 \\
30 & 7.8 & 4.3 & 3.1 & 2.3 \\
60 & 10.5 & 5.6 & 4.0 & 3.1 \\
90 & 13.1 & 7.0 & 5.0 & 3.9 \\
\hline
\end{tabular}

FLOW DURATION

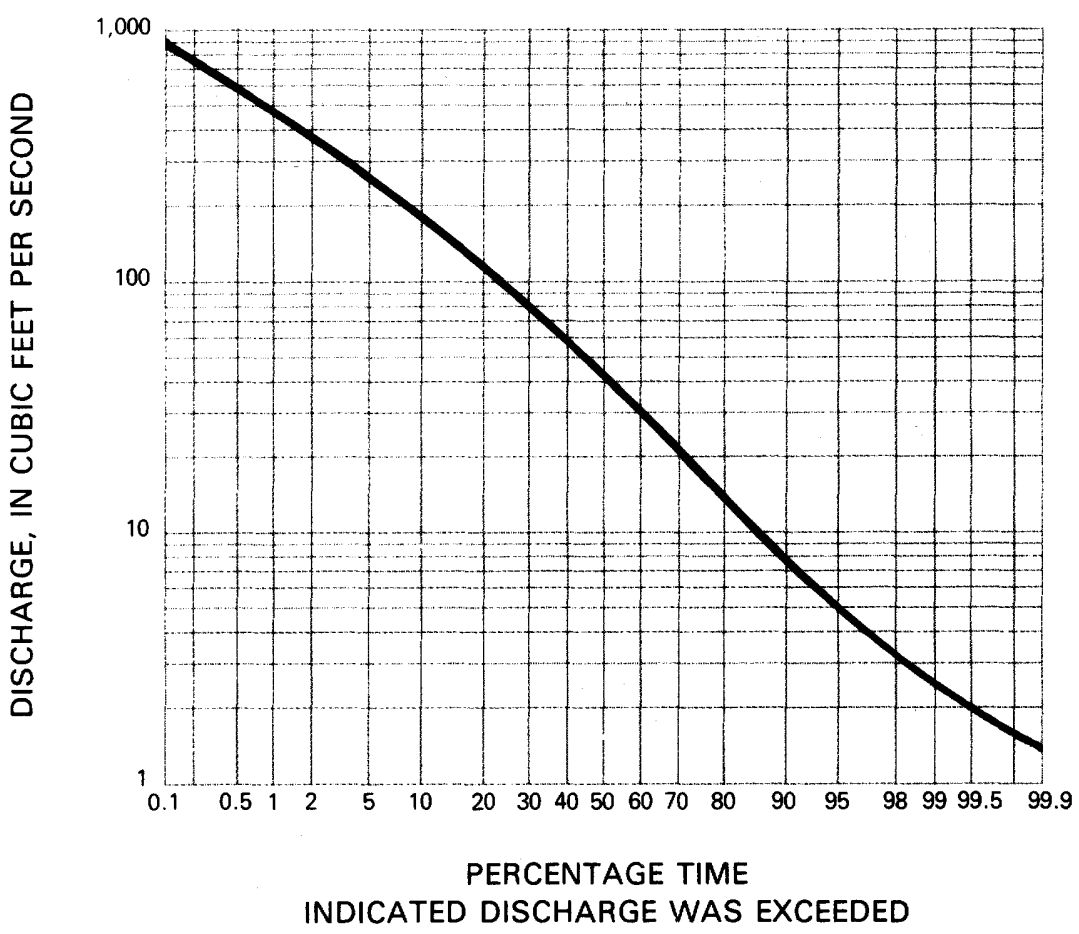



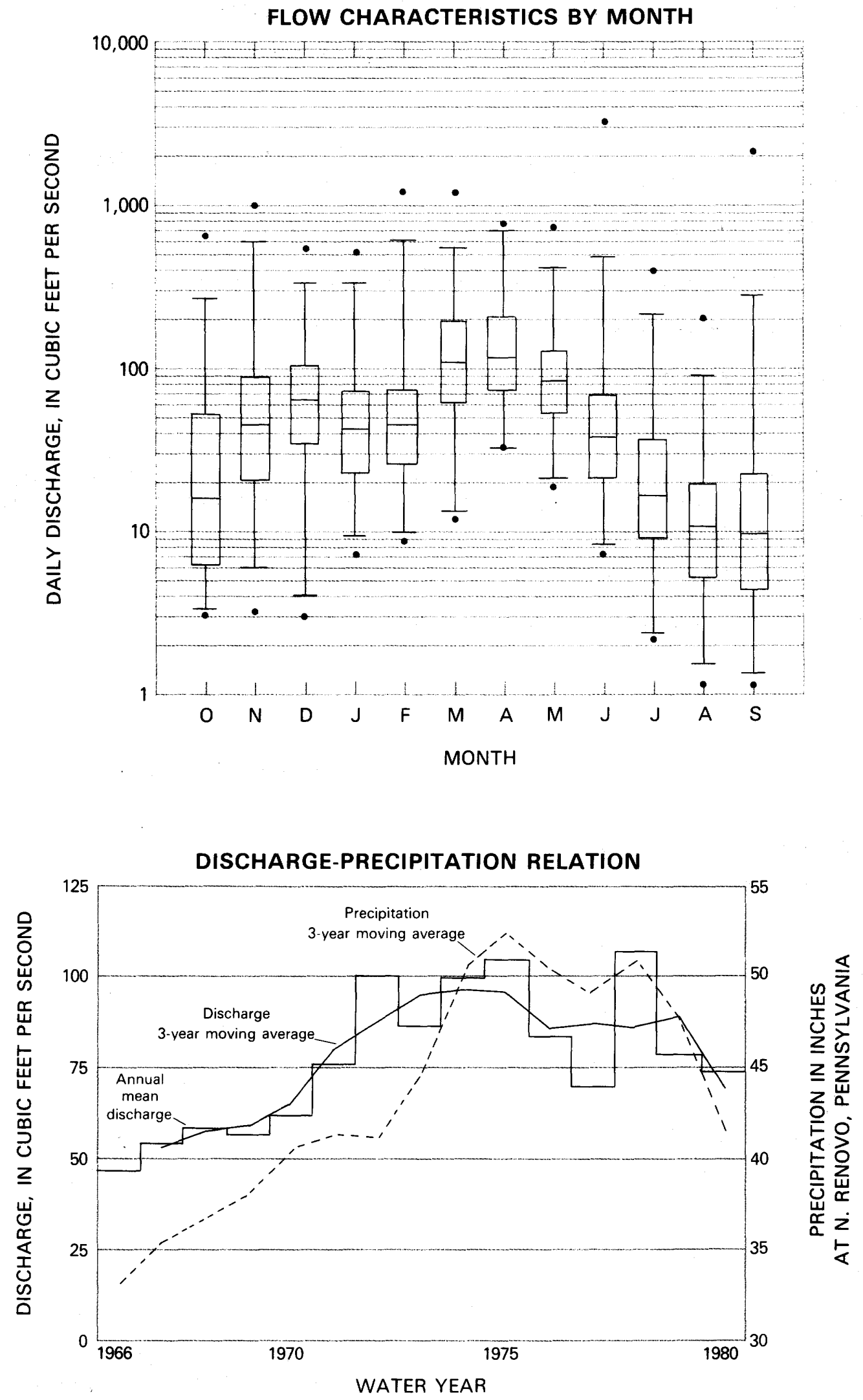
Station 44.-Scape Ore Swamp near Bishopville, SC (02135300)

Location: Lat $34^{\circ} 09^{\prime} 02^{\prime \prime}$, long $80^{\circ} 18^{\prime} 18^{\prime \prime}$, Lee County, 5.8 mi southwest of Bishopville.

Drainage area: $96.0 \mathrm{mi}^{2}$.

Topography: The general surface of the land is composed of sand hills. The general elevation of the divide is about $300 \mathrm{ft}$. The basin elevations range from 220 to $400 \mathrm{ft}$. The slope of the main stream is about $6 \mathrm{ft} / \mathrm{mi}$.

Rock type: Loosely consolidated Cretaceous sedimentary rock composed of layers of silt, sand, clay, and gravel overlain by permeable soils ranging from coarse sand to sandy loam.

Vegetation: About 50 percent of the basin is covered with pine and hardwood forest, and about 50 percent is pasture, orchards, or cultivated land.

Manmade influences: About 50 percent of the basin is agricultural. There are several small ponds. A few roads including Interstate Route 20 traverse the basin. Some seasonal irrigation may occur during severe droughts.

Period of records: July 1968 to September 1980.

Average discharge: $111 \mathrm{ft}^{3} / \mathrm{s}$

Extremes: Maximum discharge, 1,700 ft³/s, September 7, 1979, gage height, $8.54 \mathrm{ft}$; minimum daily, $6.7 \mathrm{ft}^{3} / \mathrm{s}$, July 21, 1970.

Serial correlation coefficient for annual mean discharges: -0.498 .

Kendall's tau correlation coefficient for annual mean discharges: 0.000 .

\begin{tabular}{|c|rrrr|}
\hline \multicolumn{5}{|c|}{ FLOOD FREQUENCY } \\
\hline \multicolumn{4}{|c|}{ Peak discharge, in cubic feet per second, for } \\
indicated recurrence interval, in years \\
\hline $\begin{array}{c}\text { R. I. } \\
\text { Discharge }\end{array}$ & 2 & 5 & 10 & 25 \\
\hline
\end{tabular}

Standard Deviation (logs): 0.207

Skewness Coefficient (logs): -0.002

\begin{tabular}{|r|cccc|}
\hline \multicolumn{4}{|c|}{ LOW-FLOW FREQUENCY } \\
\hline $\begin{array}{r}\text { Consecutive } \\
\text { day period }\end{array}$ & \multicolumn{3}{|c|}{$\begin{array}{l}\text { Discharge, in cubic feet per second for } \\
\text { indicated recurrence interval, in years }\end{array}$} \\
\hline & 2 & 5 & 10 & 20 \\
\cline { 2 - 5 } 7 & 19 & 13 & 11 & 8.4 \\
14 & 23 & 15 & 12 & 9.0 \\
30 & 30 & 20 & 16 & 12 \\
60 & 40 & 26 & 20 & 16 \\
90 & 47 & 32 & 26 & 22 \\
\hline
\end{tabular}

\section{FLOW DURATION}

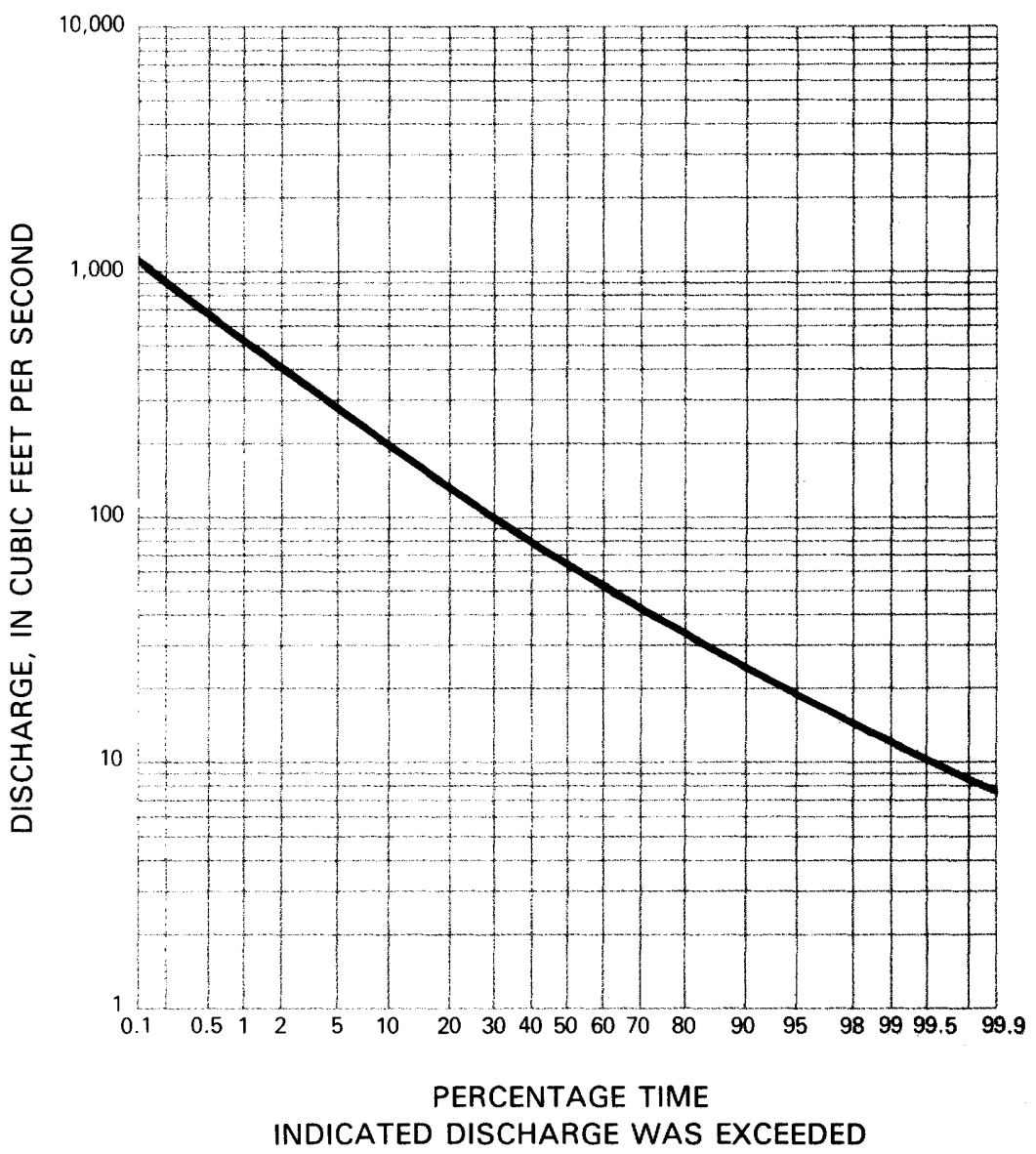



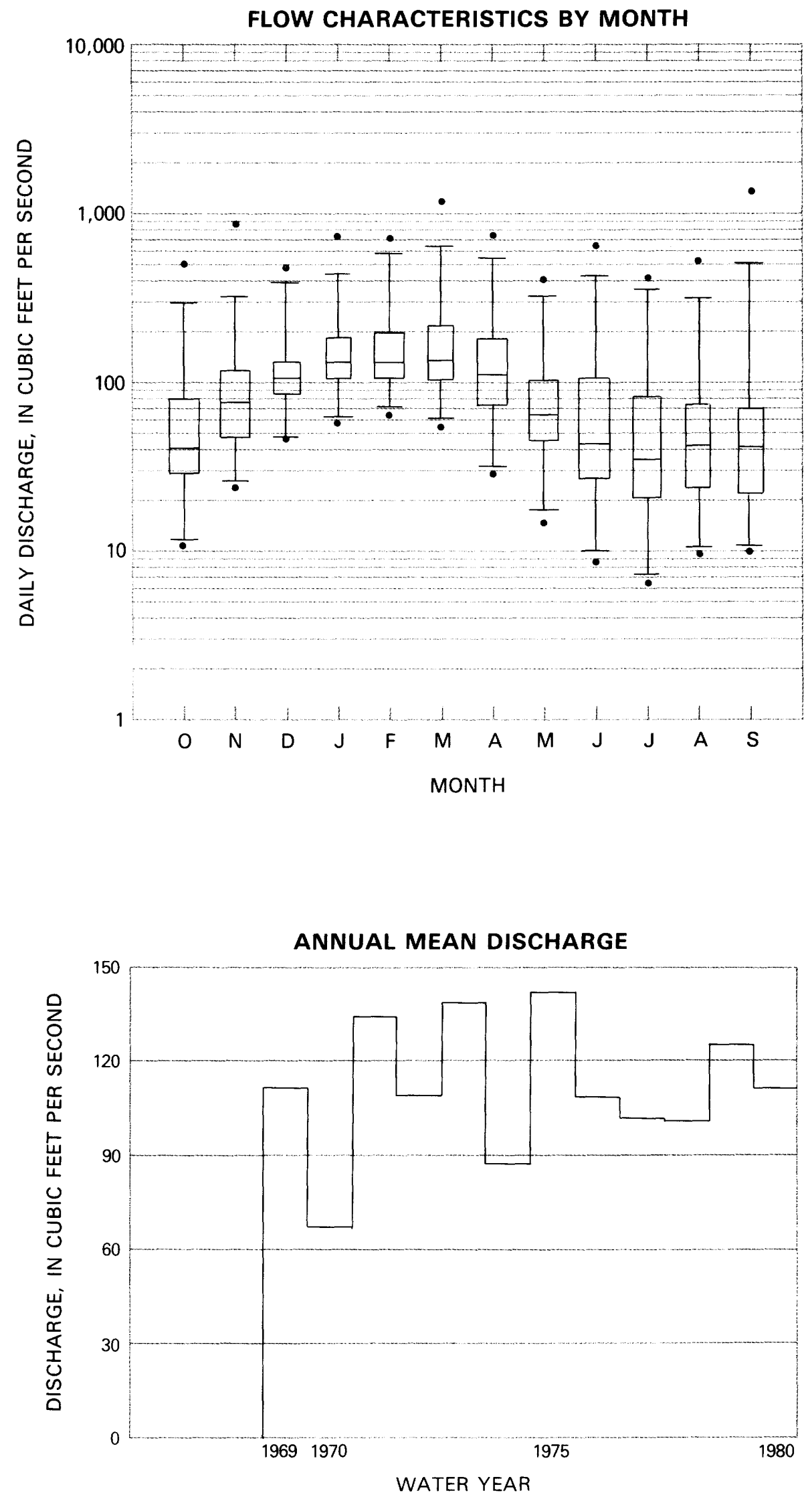
Station 45.-- Upper Three Runs near New Ellenton, SC (02197300)

Location: Lat $33^{\circ} 23^{\prime} 05^{\prime \prime}$, long $81^{\circ} 37^{\prime} 00^{\prime \prime}$, Aiken County, 4.6 mi southeast of New Ellenton.

Drainage area: $87 \mathrm{mi}^{2}$.

Topography: Sand hills are the dominant feature of the land surface. The general elevation of the divide is about 400 $\mathrm{ft}$. Basin elevations range from 230 to $500 \mathrm{ft}$. The slope of the main stream is about $15 \mathrm{ft} / \mathrm{mi}$.

Rock type: Loosely consolidated Cretaceous sedimentary rock composed of layers of silt, sand, clay, and gravel overlain by permeable soils ranging from coarse sand to sandy loam.

Vegetation: About 90 percent of the basin is covered with pine and hardwood forests, and about 10 percent is pasture, orchards, or cultivated land.

Manmade influences: Farms and rural homes make up about 10 percent of the basin. There are several small ponds. A few surfaced roads traverse the basin.

Period of record: June 1966 to September 1980.

Average discharge: $112 \mathrm{ft}^{3} / \mathrm{s}$.

Extremes: Maximum discharge, $420 \mathrm{ft}^{3} / \mathrm{s}$, August 17, 1971, gage height, $8.00 \mathrm{ft}$; minimum, $66 \mathrm{ft}^{3} / \mathrm{s}$, September 14,1969 .

Serial correlation coefficient for annual mean discharges: 0.461 .

Kendall's tau correlation coefficient for annual mean discharges: 0.209.

\begin{tabular}{|c|rrrr|}
\hline \multicolumn{5}{|c|}{ FLOOD FREQUENCY } \\
\hline \multicolumn{4}{|c|}{$\begin{array}{l}\text { Peak discharge, in cubic feet per second, for } \\
\text { indicated recurrence interval, in years }\end{array}$} \\
\hline $\begin{array}{c}\text { R. I. } \\
\text { Discharge }\end{array}$ & 2 & 5 & 10 & 25 \\
\hline
\end{tabular}

Standard Deviation (logs): 0.082

Skewness Coefficient (logs): -0.046

\begin{tabular}{|c|cccc|}
\hline \multicolumn{5}{|c|}{ LOW-FLOW FREQUENCY } \\
\hline $\begin{array}{l}\text { Consecutive } \\
\text { day period }\end{array}$ & \multicolumn{3}{|c|}{$\begin{array}{l}\text { Discharge, in cubic feet per second for } \\
\text { indicated recurrence interval, in years }\end{array}$} \\
\hline & 2 & 5 & 10 & 20 \\
\cline { 2 - 5 } 7 & 90 & 81 & 76 & 71 \\
14 & 92 & 83 & 77 & 73 \\
30 & 95 & 86 & 80 & 76 \\
60 & 99 & 89 & xx & 79 \\
90 & 101 & 92 & 86 & 82 \\
\hline
\end{tabular}

\section{FLOW DURATION}

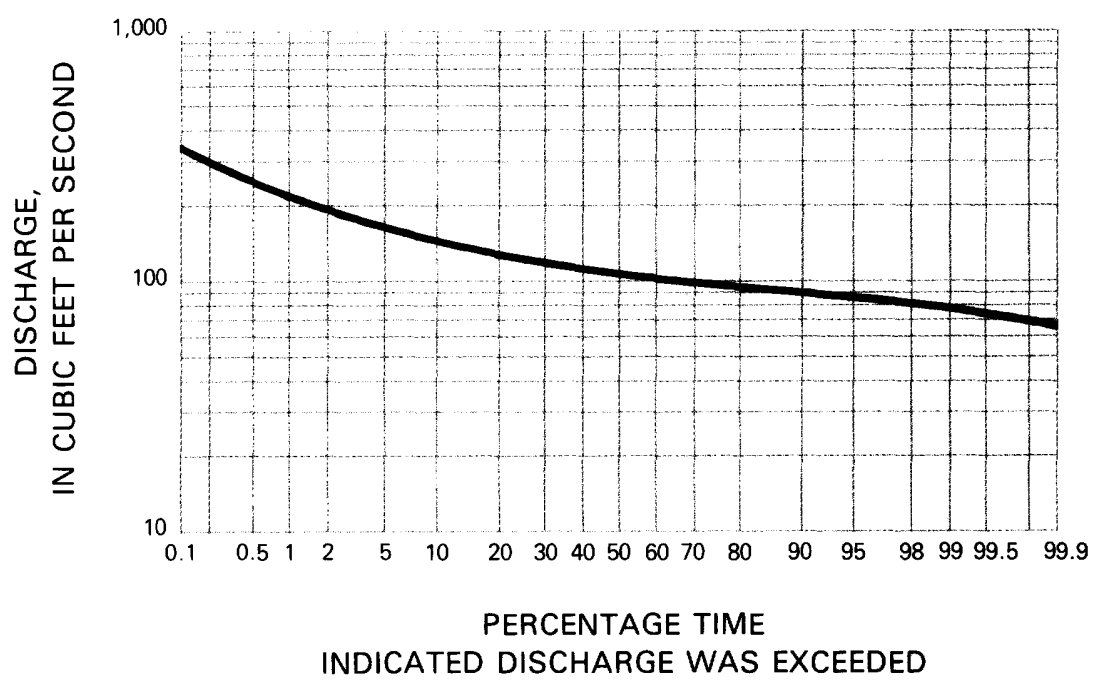



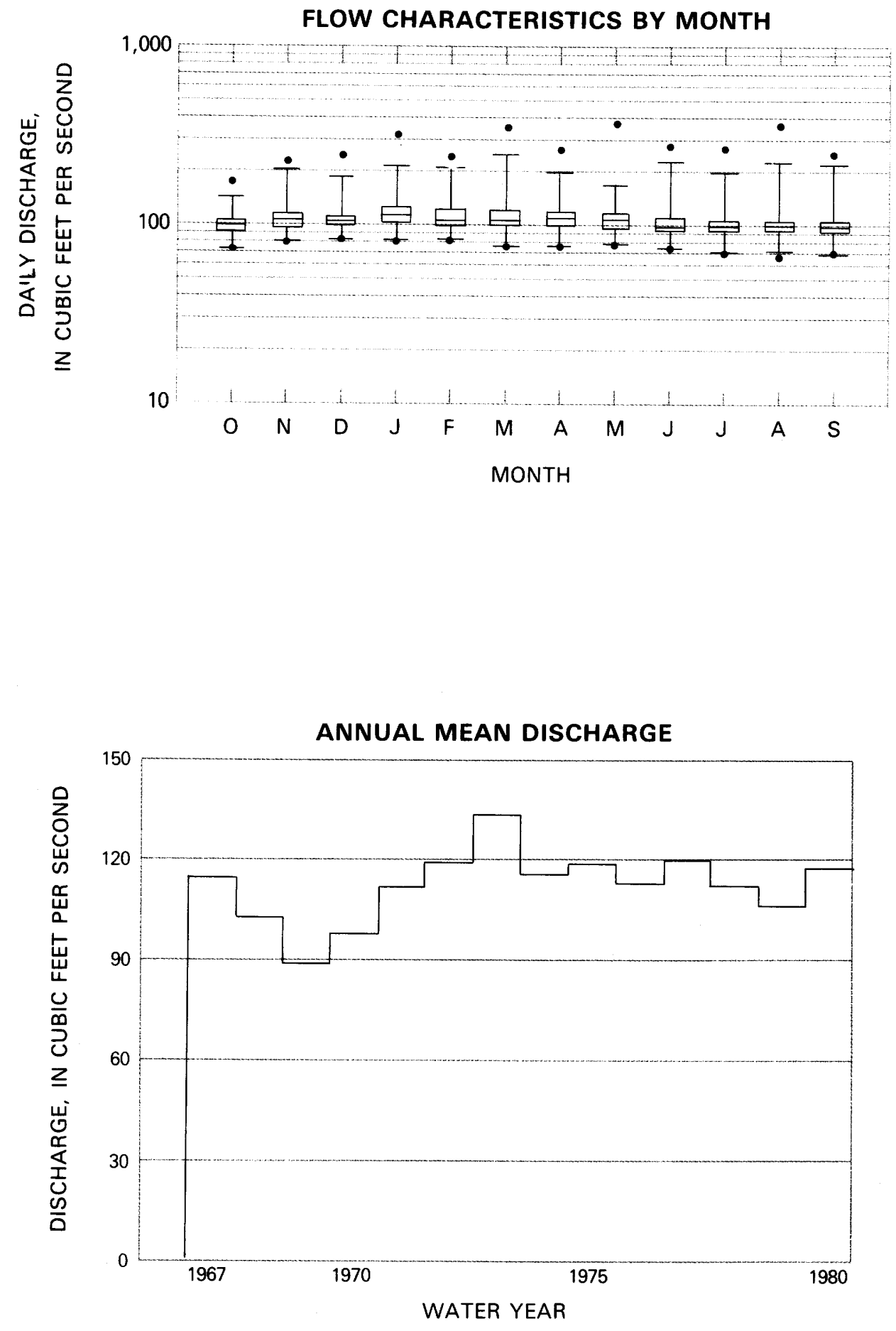
Station 46. - Castle Creek near Hill City, SD (06409000)

Location: Lat $44^{\circ} 00^{\prime} 49^{\prime \prime}$, long $103^{\circ} 49^{\prime} 48^{\prime \prime}$, Pennington County, 14 mi northwest of Hill City.

Drainage area: $83 \mathrm{mi}^{2}$, approximately.

Topography: Maturely dissected domed mountains. Basin elevations range from 5,910 to about 7,130 ft. The main stream slope is about $65 \mathrm{ft} / \mathrm{mi}$.

Rock type: Predominantly limestone.

Vegetation: About 90 percent of the basin is covered by a moderately dense forest of predominantly ponderosa pine. There are also some spruce, aspen, and willows, as well as other small types of trees and brush, particularly in the valley areas.

Manmade influences: The basin is in the Black Hills National Forest. Mature timber has been harvested one or more times throughout the basin. Hay and grains are grown in some of the narrow valley meadows. Grazing is permitted. A few stock-water ponds and several roads and trails are in the basin.

Period of record: June 1948 to September 1980.

Average discharge: $10.3 \mathrm{ft}^{3} / \mathrm{s}$.

Extremes: Maximum discharge, 1,120 ft $\mathrm{f}^{3} / \mathrm{s}$, May 22, 1952, gage height, $5.81 \mathrm{ft}$, from rating curve extended above slopearea measurement at gage height, $5.67 \mathrm{ft}$; minimum, $1.2 \mathrm{ft}^{3} / \mathrm{s}$, April 25, 1969; minimum gage height, $1.35 \mathrm{ft}$, November 12, 1949, February 19, 1954, March 7, 1957, March 29, 1961.

Serial correlation coefficient for annual mean discharges: 0.770 .

Kendall's tau correlation coefficient for annual mean discharges: 0.282.

\begin{tabular}{|c|c|c|c|c|c|}
\hline \multicolumn{6}{|c|}{ FLOOD FREQUENCY } \\
\hline \multicolumn{6}{|c|}{$\begin{array}{l}\text { Peak discharge, in cubic feet per second, for } \\
\text { indicated recurrence interval, in years }\end{array}$} \\
\hline $\begin{array}{c}\text { R. I. } \\
\text { Discharge }\end{array}$ & $\begin{array}{c}2 \\
53.7\end{array}$ & $\begin{array}{r}5 \\
123\end{array}$ & $\begin{array}{r}10 \\
202\end{array}$ & $\begin{array}{r}50 \\
545\end{array}$ & $\begin{array}{l}100 \\
801\end{array}$ \\
\hline
\end{tabular}

Standard Deviation (logs): 0.395

Skewness Coefficient (logs): 0.736

\begin{tabular}{|c|ccccc|}
\hline \multicolumn{5}{|c|}{ LOW-FLOW FREQUENCY } \\
\hline $\begin{array}{l}\text { Consecutive } \\
\text { day period }\end{array}$ & \multicolumn{4}{|c|}{$\begin{array}{l}\text { Discharge, in cubic feet per second for } \\
\text { indicated recurrence interval, in years }\end{array}$} \\
\hline & 2 & 5 & 10 & 50 & 100 \\
\cline { 2 - 6 } 7 & 6.2 & 4.6 & 3.8 & 2.6 & 2.3 \\
14 & 6.6 & 4.9 & 4.0 & 2.7 & 2.3 \\
30 & 7.0 & 5.3 & 4.4 & 3.0 & 2.6 \\
60 & 7.3 & 5.6 & 4.8 & 3.6 & 3.2 \\
90 & 7.6 & 5.8 & 5.0 & 3.7 & 3.3 \\
\hline
\end{tabular}

\section{FLOW DURATION}

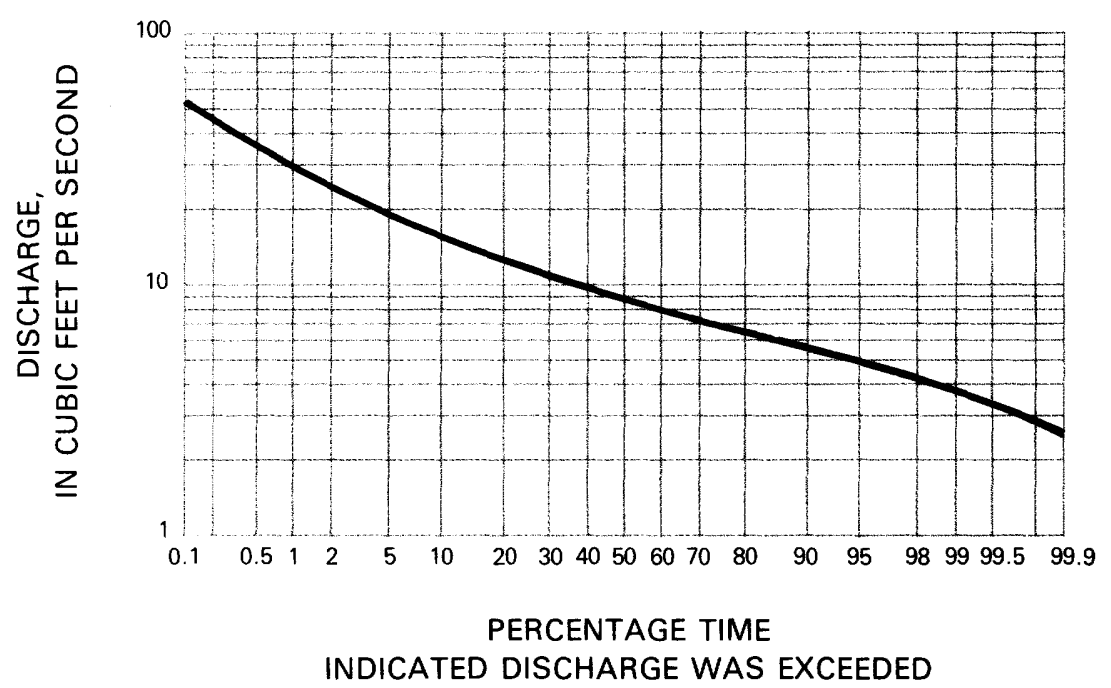



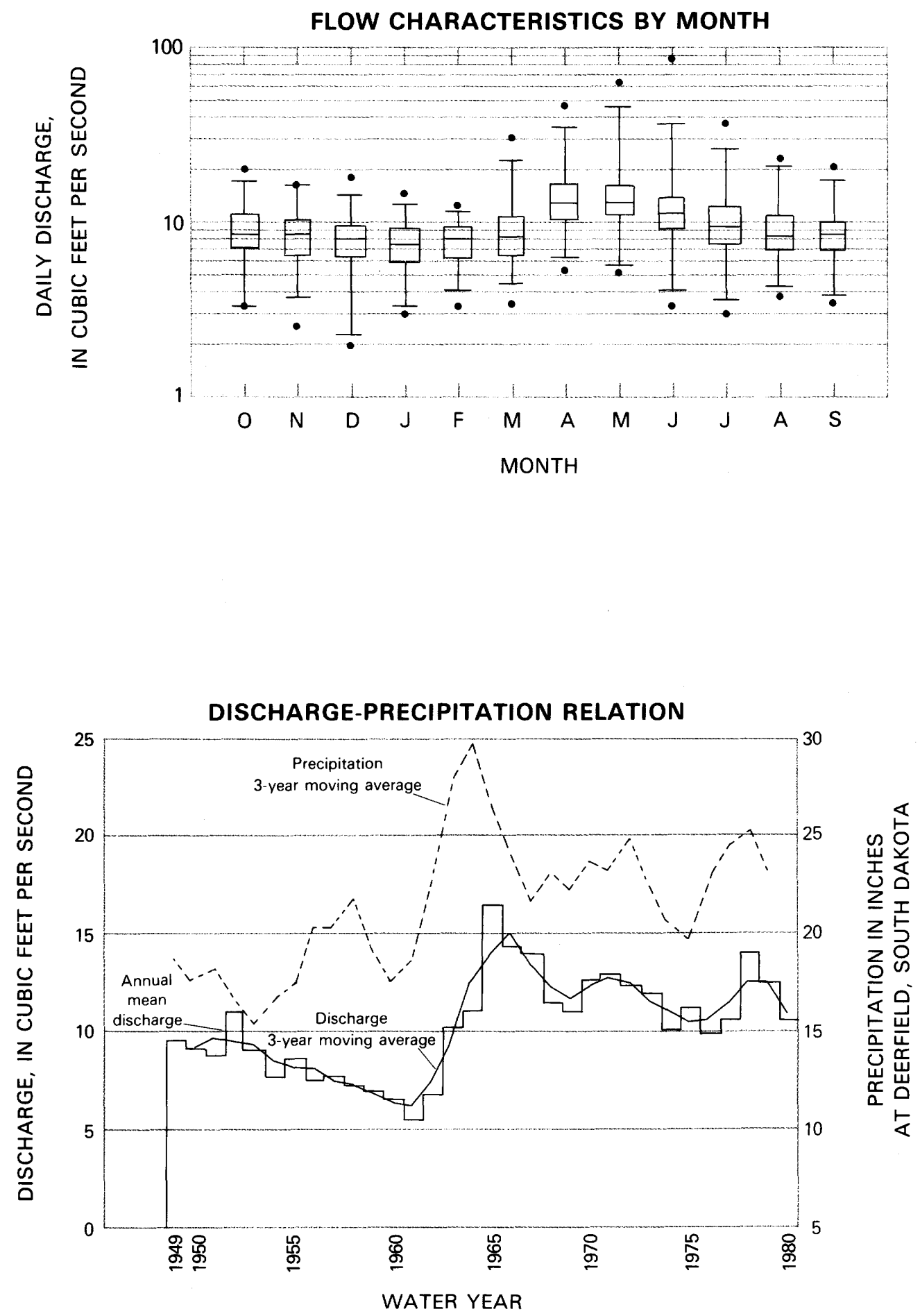
Location: Lat $43^{\circ} 47^{\prime} 40^{\prime \prime}$, long $92^{\circ} 22^{\prime} 02^{\prime \prime}$, McCook County, 5.2 mi northeast of Salem.

Drainage area: $51 \mathrm{mi}^{2}$, approximately.

Topography: Rather flat, young glaciated plain. Basin elevations range from 1,530 to 1,630 ft. The slope of the main stream is about $6 \mathrm{ft} / \mathrm{mi}$.

Rock type: Thin alluvium in valley over glacial till. The bedrock is quartzite beneath about $200 \mathrm{ft}$ of drift.

Vegetation: About 10 percent of the basin is covered with a moderately dense growth of prairie grass. About 90 percent of the basin is under cultivation, grains are the main crops. The only trees of significance are shelterbelts associated with farmsteads.

Manmade influences: The entire basin is devoted to agriculture. Most of it is cultivated, with some grazing. There are a few small stock ponds. Many graded roads traverse the basin.

Period of record: September 1966 to September 1980.

Average discharge: $2.11 \mathrm{ft}^{3} / \mathrm{s}$.

Extremes: Maximum discharge, $676 \mathrm{ft}^{3} / \mathrm{s}$, March 21, 1978, gage height, $7.79 \mathrm{ft}$; maximum gage height, $8.53 \mathrm{ft}$, April 5, 1969 (backwater from ice); no flow for many days each year.

Serial correlation coefficient for annual mean discharges: 0.125.

Kendall's tau correlation coefficient for annual mean discharges: 0.044 .

\begin{tabular}{|c|rrrr|}
\hline \multicolumn{5}{|c|}{ FLOOD FREQUENCY } \\
\hline \multicolumn{4}{|c|}{ Peak discharge, in cubic feet per second, for } \\
indicated recurrence interval, in years \\
\hline R. I. & 2 & 5 & 10 & 25 \\
Discharge & 41 & 283 & 689 & 1,630 \\
\hline
\end{tabular}

Standard Deviation (logs): 1.092

Skewness Coefficient (logs): -0.535

\begin{tabular}{|c|c|c|c|c|}
\hline \multicolumn{5}{|c|}{ LOW-FLOW FREQUENCY } \\
\hline $\begin{array}{l}\text { Consecutive } \\
\text { day period }\end{array}$ & \multicolumn{4}{|c|}{$\begin{array}{l}\text { Discharge, in cubic feet per second for } \\
\text { indicated recurrence interval, in years }\end{array}$} \\
\hline & 2 & 5 & 10 & 20 \\
\hline $\begin{array}{r}7 \\
14 \\
30 \\
60 \\
90\end{array}$ & & \multicolumn{3}{|c|}{$\begin{array}{l}\text { Long periods of no } \\
\text { flow for all years. }\end{array}$} \\
\hline
\end{tabular}

\section{FLOW DURATION}

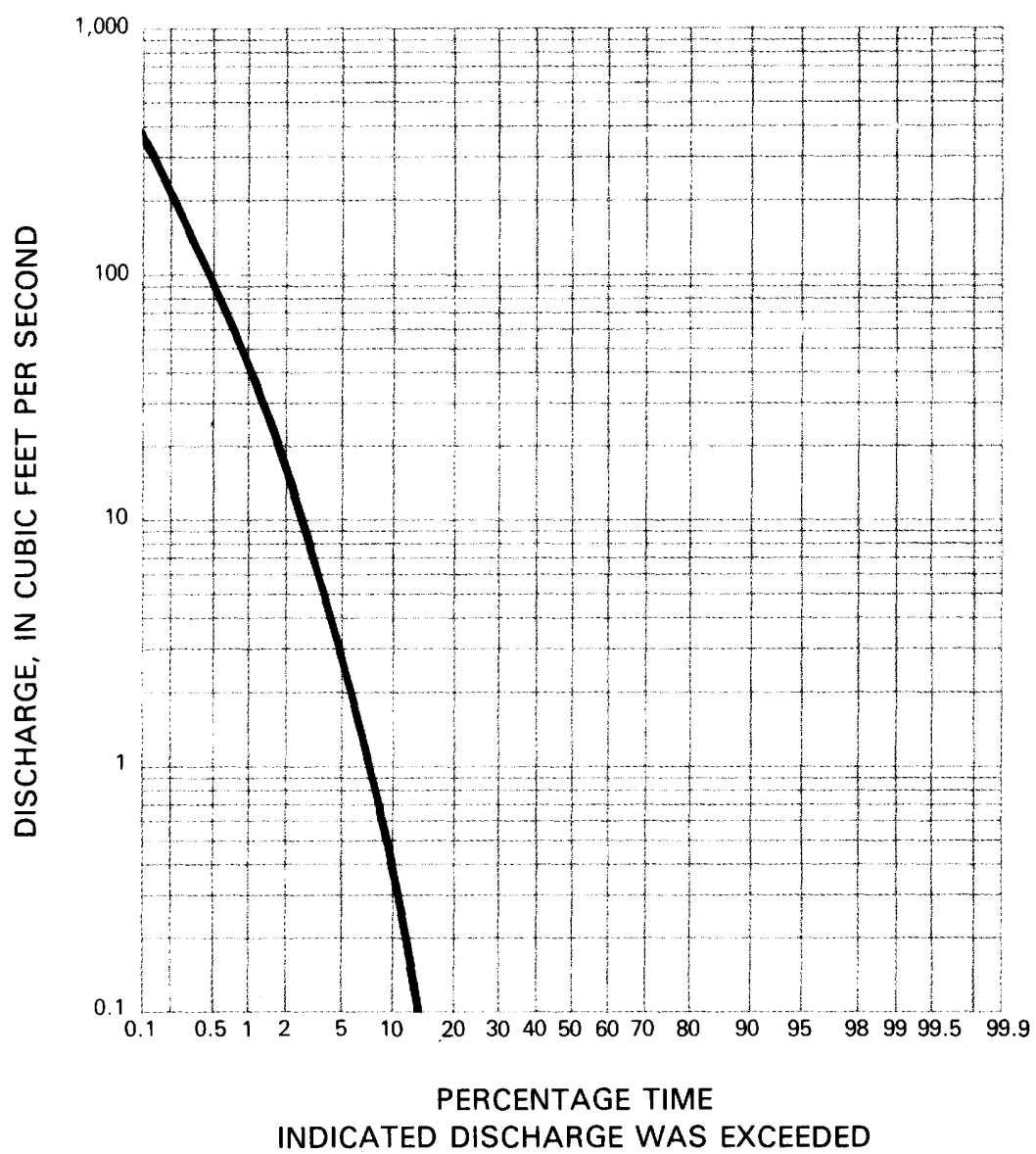



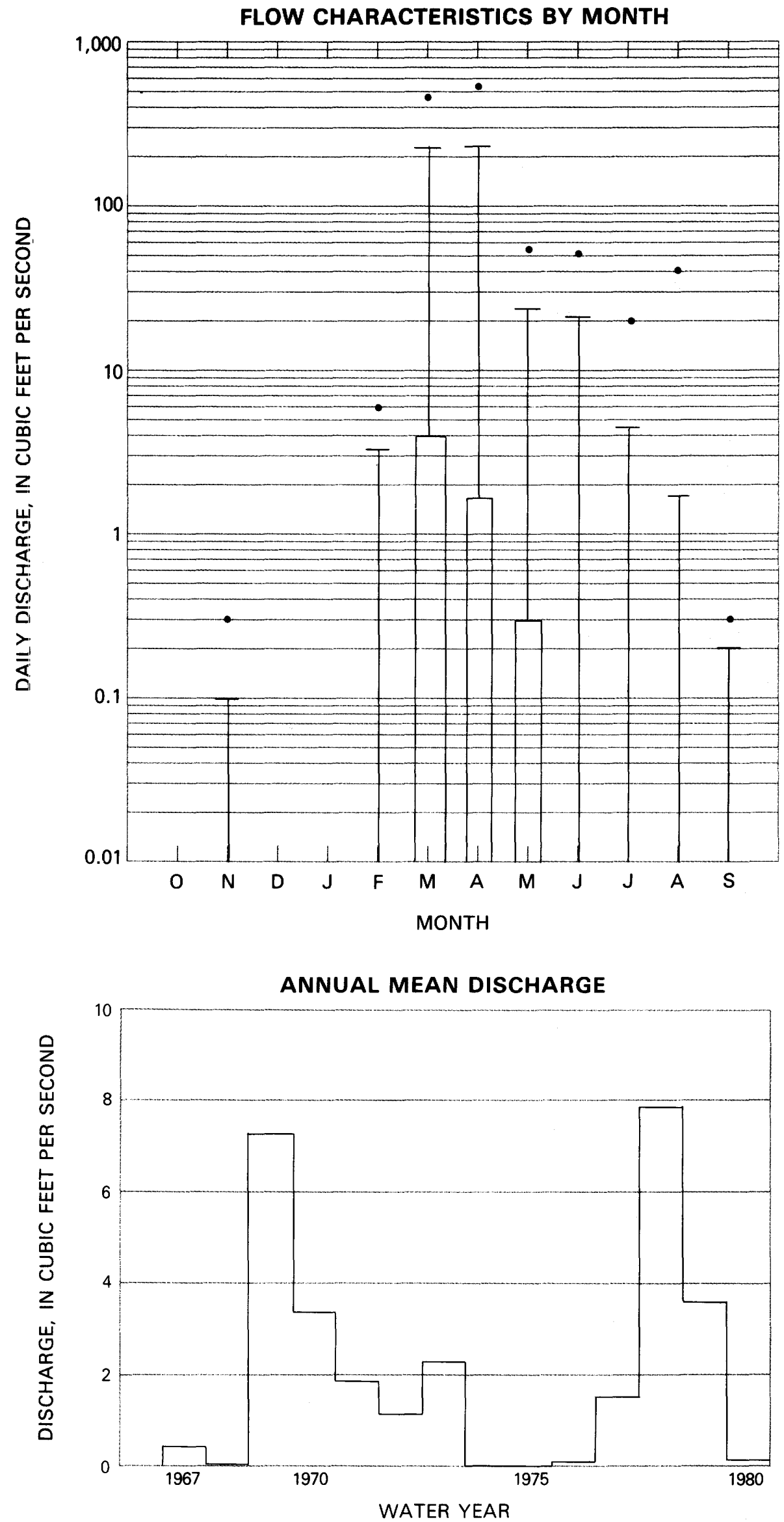
Station 48. - Buffalo River near Flat Woods, TN (03604000)

Location: Lat $35^{\circ} 29^{\prime} 45^{\prime \prime}$, long $87^{\circ} 49^{\prime} 58^{\prime \prime}$, Perry County, 1.3 mi north of Flat Woods.

Drainage area: $447 \mathrm{mi}^{2}$.

Topography: Buffalo River meanders in an alluvial valley, 0.25 to $1 \mathrm{mi}$ in width. Valley slopes are moderately steep. Basin elevations range from 514 to about $1,000 \mathrm{ft}$.

Rock type: The principal surface rock is chert. In the stream valleys downstream from Grinder's Creek, there are small outcrops of limestone, shale, and sandstone.

Vegetation: About 65 percent of the basin is forested, principally with hardwoods, but with a scattering of pine and cedar. The forest is very dense in ravines and valleys and moderately dense to sparse along the ridges. About 25 percent of the area is cleared land, mostly in the wider valleys. The cleared land is split between cropland (15 percent) and pastureland (10 percent).

Manmade influences: Waynesboro (population 2,109) and several smaller communities are in the basin. Hohenwold (population 3,922) is on the northern drainage divide, with part of the town outside of the area. Two small impoundments, Laurel Hill Lake and Napier Lake, are located in the basin. Several roads traverse the basin. During the past 20 years there has been a decrease of about 20 percent in farm acreage. Part of the basin is classified as a State Scenic River area. Canoeing has become a popular recreational use of the river.

Period of record: May 1920 to September 1980.

Average discharge: $757 \mathrm{ft}^{3} / \mathrm{s}$.

Extremes: Maximum discharge, $90,000 \mathrm{ft} / \mathrm{s}$, February 13, 1948, gage height, $32.0 \mathrm{ft}$, from high-water mark in gage house, from rating curve extended above $50,000 \mathrm{ft}^{3} / \mathrm{s}$ on basis of slope-area and contracted-opening measurements of peak flow and rainfall-runoff study; minimum, $65 \mathrm{ft}^{3} / \mathrm{s}$, September $9,1925$.

Serial correlation coefficient for annual mean discharges: 0.250.

Kendall's tau correlation coefficient for annual mean discharges: 0.132 .

\begin{tabular}{|c|rrrrr|}
\hline \multicolumn{7}{|c|}{ FLOOD FREQUENCY } \\
\hline \multicolumn{5}{|c|}{ Peak discharge, in cubic feet per second, for } \\
indicated recurrence interval, in years \\
\hline $\begin{array}{c}\text { R. I. } \\
\text { Discharge }\end{array}$ & 2 & 5 & 10 & 50 & 100 \\
\hline
\end{tabular}

Standard Deviation (logs): 0.284

Skewness Coefficient (logs): 0.230

\begin{tabular}{|c|ccccr|}
\hline \multicolumn{5}{|c|}{ LOW-FLOW FREQUENCY } \\
\hline $\begin{array}{c}\text { Consecutive } \\
\text { day period }\end{array}$ & \multicolumn{4}{|c|}{$\begin{array}{l}\text { Discharge, in cubic feet per second for } \\
\text { indicated recurrence interval, in years }\end{array}$} \\
\hline & 2 & 5 & 10 & 50 & 100 \\
\cline { 2 - 6 } 7 & 149 & 118 & 105 & 87 & 82 \\
14 & 155 & 124 & 111 & 93 & 87 \\
30 & 171 & 136 & 122 & 102 & 96 \\
60 & 190 & 153 & 138 & 118 & 112 \\
90 & 209 & 167 & 150 & 128 & 122 \\
\hline
\end{tabular}

\section{FLOW DURATION}

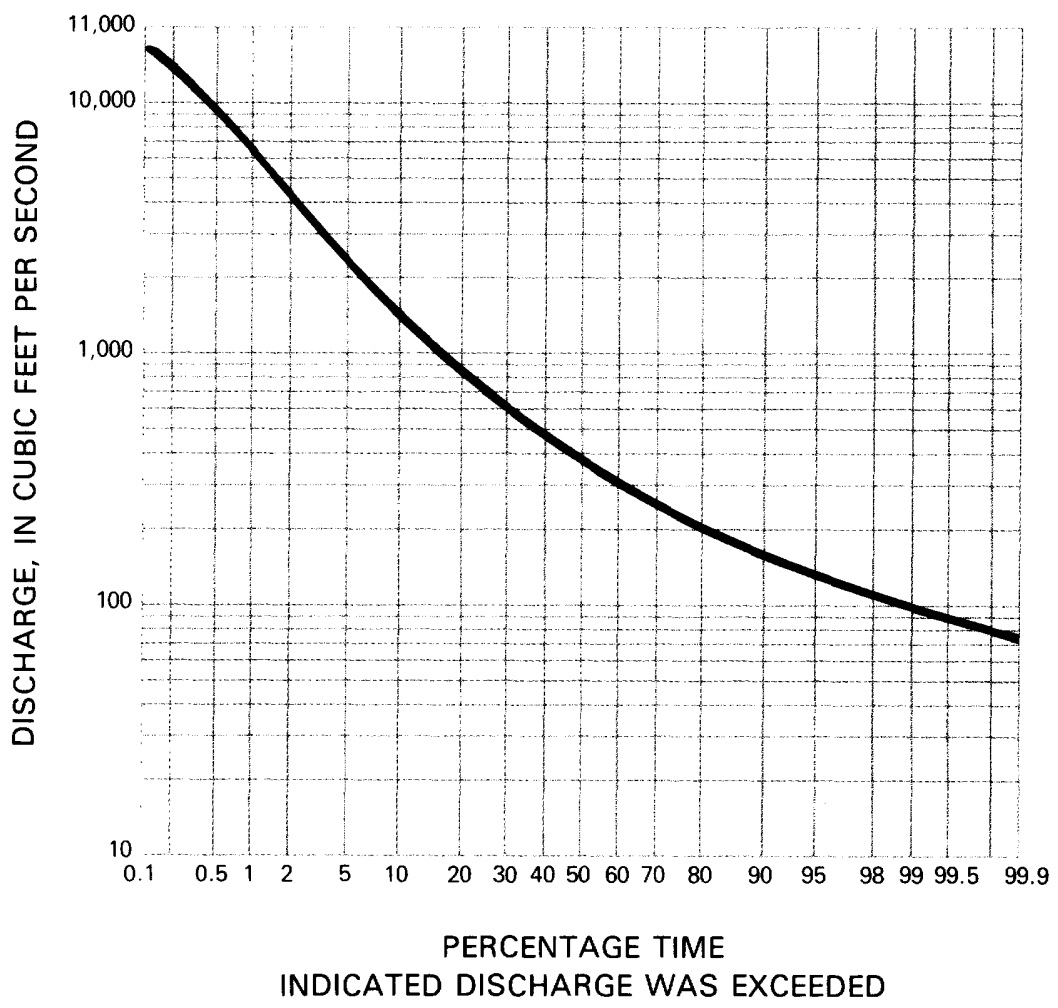



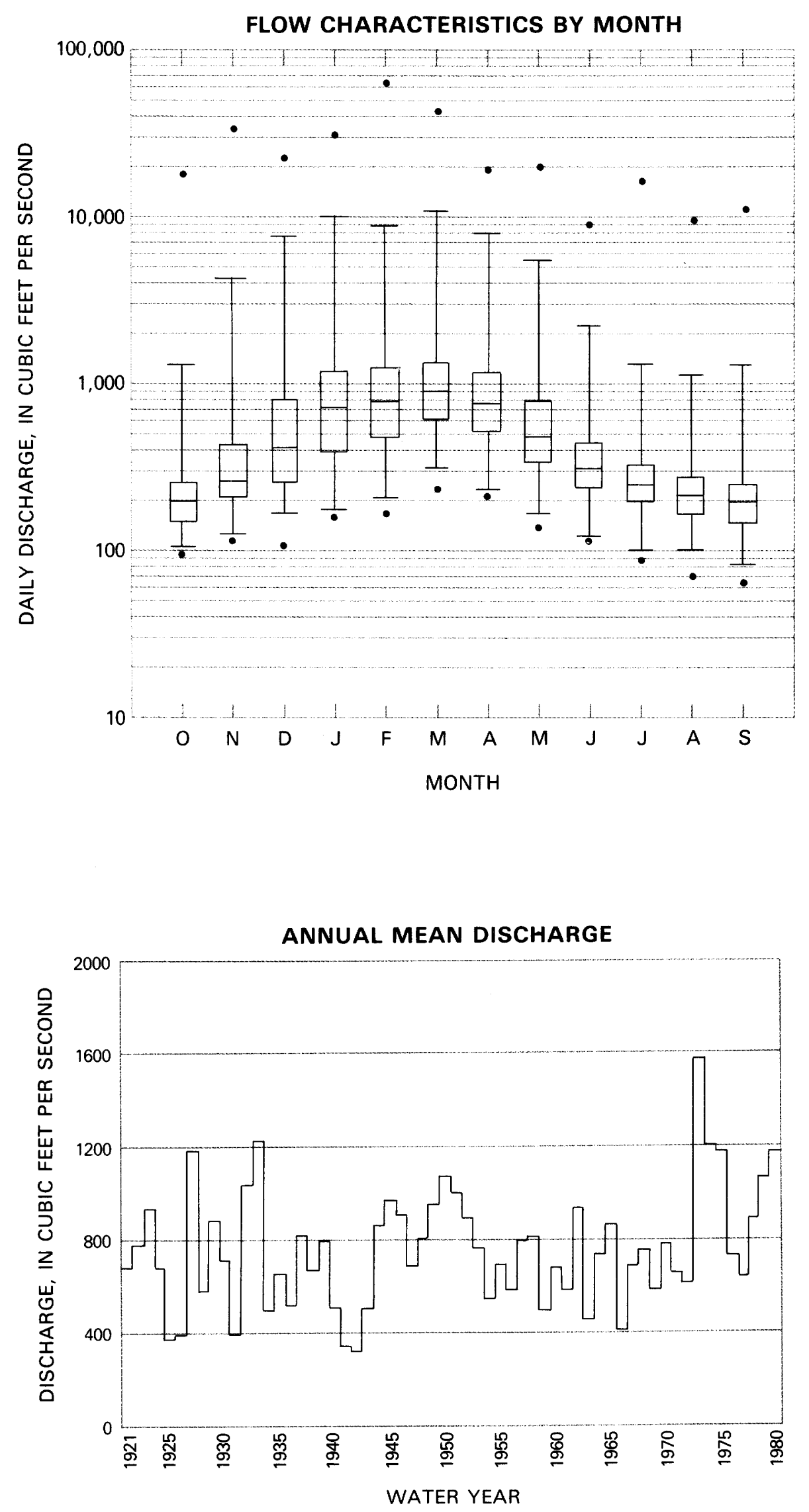
Station 49. - Little River above Townsend, TN (03497300)

Location: Lat $35^{\circ} 39^{\prime} 52^{\prime \prime}$, long $83^{\circ} 42^{\prime} 41^{\prime \prime}$, Blound County, 2.2 mi southeast of Townsend.

Drainage area: $106 \mathrm{mi}^{2}$.

Topography: Very mountainous terrain. Divides are high and valleys are narrow. Basin elevations range from 1,110 to $6,640 \mathrm{ft}$.

Rock type: The basin is underlain by partly metamorphosed shale, siltstone, sandstone, and conglomerate.

Vegetation: Forests of mixed hardwoods completely cover the basin up to about 5,000 ft. Above this elevation a forest of spruce and fir dominates.

Manmade influences: The basin is entirely within the Great Smoky Mountains National Park. Facilities involving human occupancy include several permanent residences, an Environmental Education Camp, two large campgrounds, and a few small picnic areas. Many of these facilities have been established or enlarged since 1963. One highway, a few access roads, and several nature trails traverse the basin.

Period of record: October 1963 to September 1980.

Average discharge: $294 \mathrm{ft}^{3} / \mathrm{s}$.

Extremes: Maximum discharge, 16,000 ft $3 / \mathrm{s}$, March 16, 1973, gage height, $12.30 \mathrm{ft}$; minimum, $28 \mathrm{ft}^{3} / \mathrm{s}$, September 17 , 1980, minimum gage height, $1.18 \mathrm{ft}$, September 17, 1980.

Serial correlation coefficient for annual mean discharges: 0.243 .

Kendall's tau correlation coefficient for annual mean discharges: 0.103.

FLOW DURATION

\begin{tabular}{|c|rrrr|}
\hline \multicolumn{4}{|c|}{ FLOOD FREQUENCY } \\
\hline \multicolumn{4}{|c|}{$\begin{array}{c}\text { Peak discharge, in cubic feet per second, for } \\
\text { indicated recurrence interval, in years }\end{array}$} \\
\hline R. I. & 2 & 5 & 10 & 25 \\
Discharge & 7,590 & 12,000 & 15,000 & 19,000 \\
\hline
\end{tabular}

Standard Deviation (logs): 0.242

Skewness Coefficient (logs): -0.204

\begin{tabular}{|r|rrrr|}
\hline \multicolumn{5}{|c|}{ LOW-FLOW FREQUENCY } \\
\hline $\begin{array}{r}\text { Consecutive } \\
\text { day period }\end{array}$ & \multicolumn{3}{|c|}{$\begin{array}{l}\text { Discharge, in cubic feet per second for } \\
\text { indicated recurrence interval, in years }\end{array}$} \\
\hline & \multicolumn{1}{|c}{2} & 5 & 10 & 20 \\
\cline { 2 - 5 } 7 & 54 & 42 & 37 & 33 \\
14 & 61 & 47 & 41 & 37 \\
30 & 75 & 55 & 47 & 41 \\
60 & 91 & 66 & 56 & 48 \\
90 & 111 & 78 & 65 & 56 \\
\hline
\end{tabular}

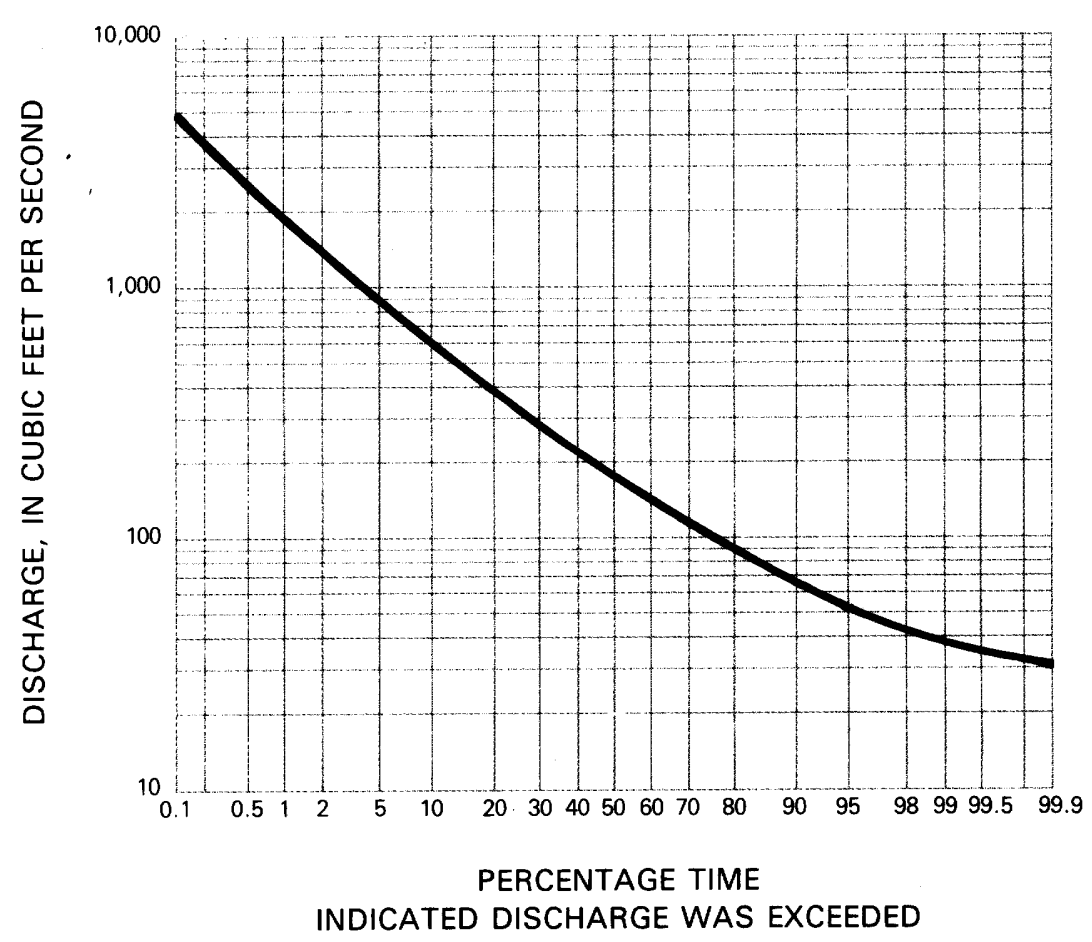


FLOW CHARACTERISTICS BY MONTH
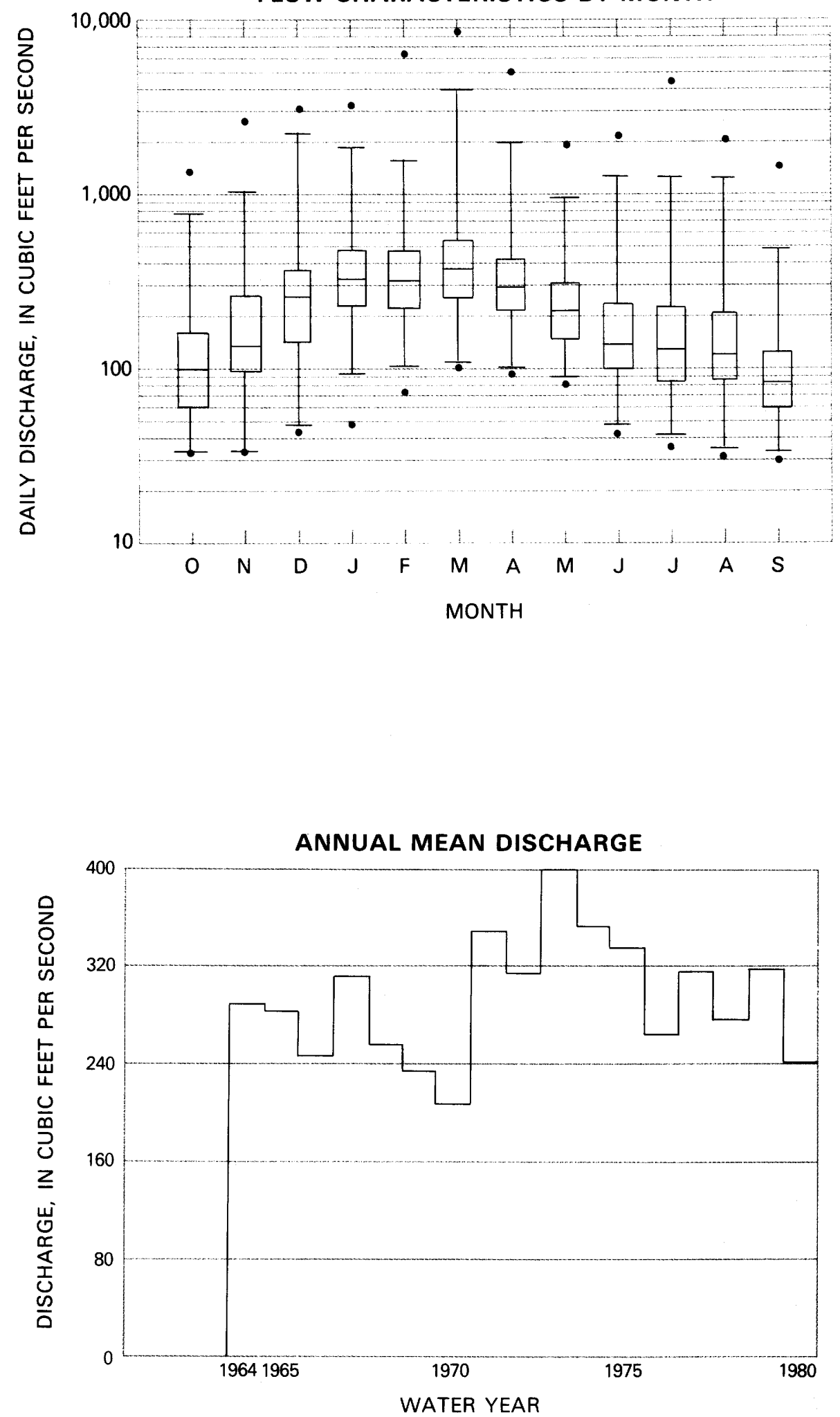
Location: Lat $30^{\circ} 36^{\prime} 48^{\prime \prime}$, long $104^{\circ} 00^{\prime} 04^{\prime \prime}$, Jeff Davis County, 6.8 mi west of Fort Davis.

Drainage area: $52.4 \mathrm{mi}^{2}$.

Topography: Mountainous. The general elevation of the divide is about 7,500 $\mathrm{ft}$. Basin elevations range from 5,200 to $8,300 \mathrm{ft}$. The slope of the main stream is about $118 \mathrm{ft} / \mathrm{mi}$.

Rock type: The area is underlain by volcanic rocks, most of which are andesites and basalts. Thin alluvial deposits of boulders, gravel, and sand occur in the stream channel.

Vegetation: Phreatophytes-such as cottonwood, willow, and saltcedar-occur along the stream channels. Oak, hackberry, and other trees sparsely cover the higher parts of the basin. Cacti, weeds, and native grasses cover most of the basin.

Manmade influences: The basin is essentially undisturbed by man. There are a few roads in the basin.

Period of record: October 1965 to September 1980.

Average discharge: $2.8 \mathrm{ft}^{3} / \mathrm{s}$.

Extremes: Maximum discharge, 3,420 ft $3 / \mathrm{s}$, September 25, 1978, gage height, $12.63 \mathrm{ft}$, present datum, from rating curve extended above $150 \mathrm{ft}^{3} / \mathrm{s}$ on basis of slope-area measurements of $1,130,1,560$, and 2,630 $\mathrm{ft}^{3} / \mathrm{s}$; no flow at times each year.

Serial correlation coefficient for annual mean discharges: -0.301 .

Kendall's tau correlation coefficient for annual mean discharges: 0.187 .

\begin{tabular}{|c|rrrr|}
\hline \multicolumn{5}{|c|}{ FLOOD FREQUENCY } \\
\hline \multicolumn{4}{|c|}{$\begin{array}{l}\text { Peak discharge, in cubic feet per second, for } \\
\text { indicated recurrence interval, in years }\end{array}$} \\
\hline $\begin{array}{c}\text { R. I. } \\
\text { Discharge }\end{array}$ & 2 & 5 & 10 & 25 \\
\hline
\end{tabular}

Standard Deviation (logs): 0.759

Skewness Coefficient (logs): -0.283

\begin{tabular}{|c|c|c|c|c|}
\hline \multicolumn{5}{|c|}{ LOW-FLOW FREQUENCY } \\
\hline $\begin{array}{l}\text { Consecutive } \\
\text { day period }\end{array}$ & \multicolumn{4}{|c|}{$\begin{array}{l}\text { Discharge, in cubic feet per second for } \\
\text { indicated recurrence interval, in years }\end{array}$} \\
\hline & 2 & 5 & 10 & 20 \\
\hline $\begin{array}{r}7 \\
14 \\
30 \\
60 \\
90\end{array}$ & & \multicolumn{3}{|c|}{$\begin{array}{l}\text { Long periods of no } \\
\text { flow for most years. }\end{array}$} \\
\hline
\end{tabular}

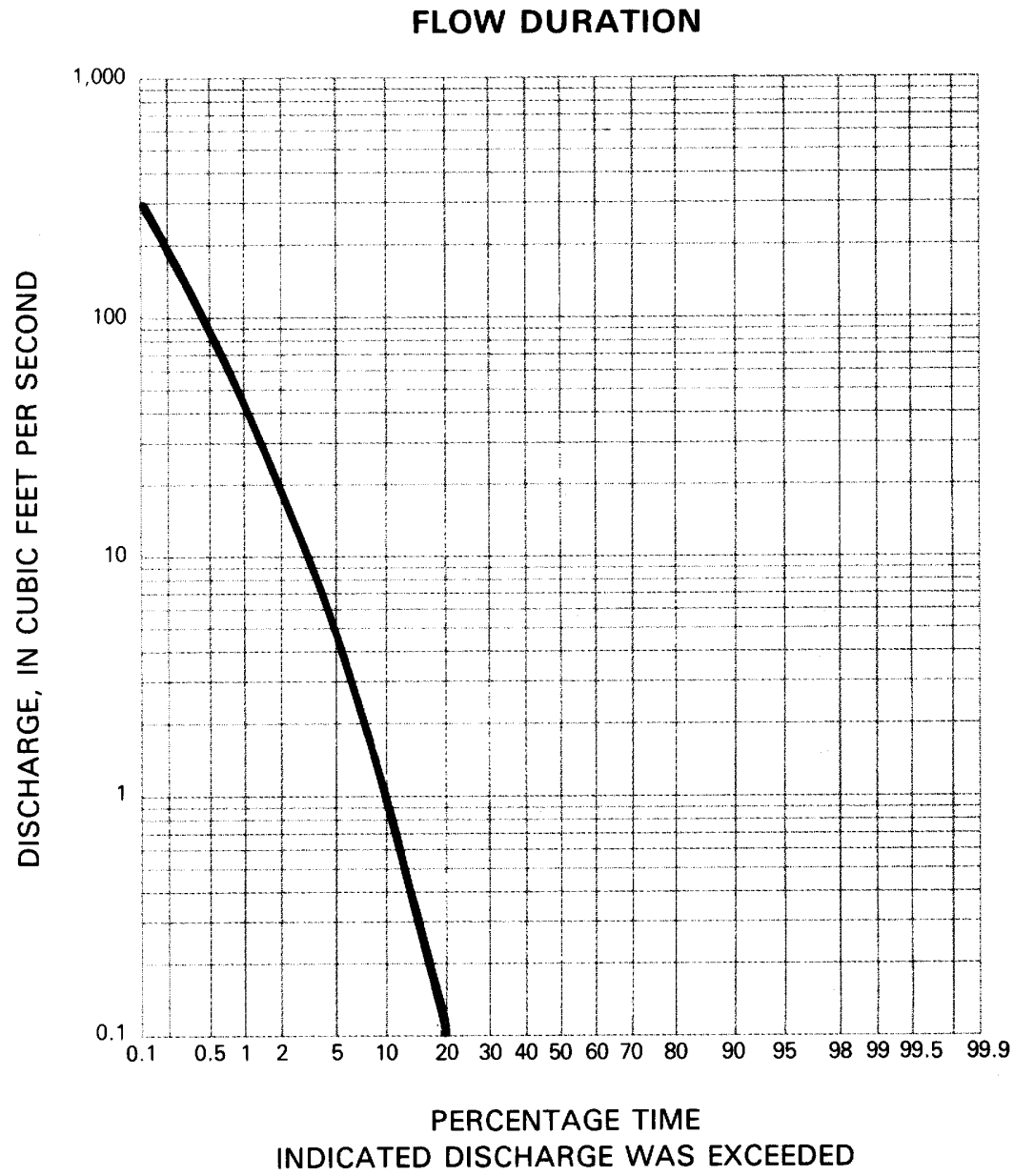



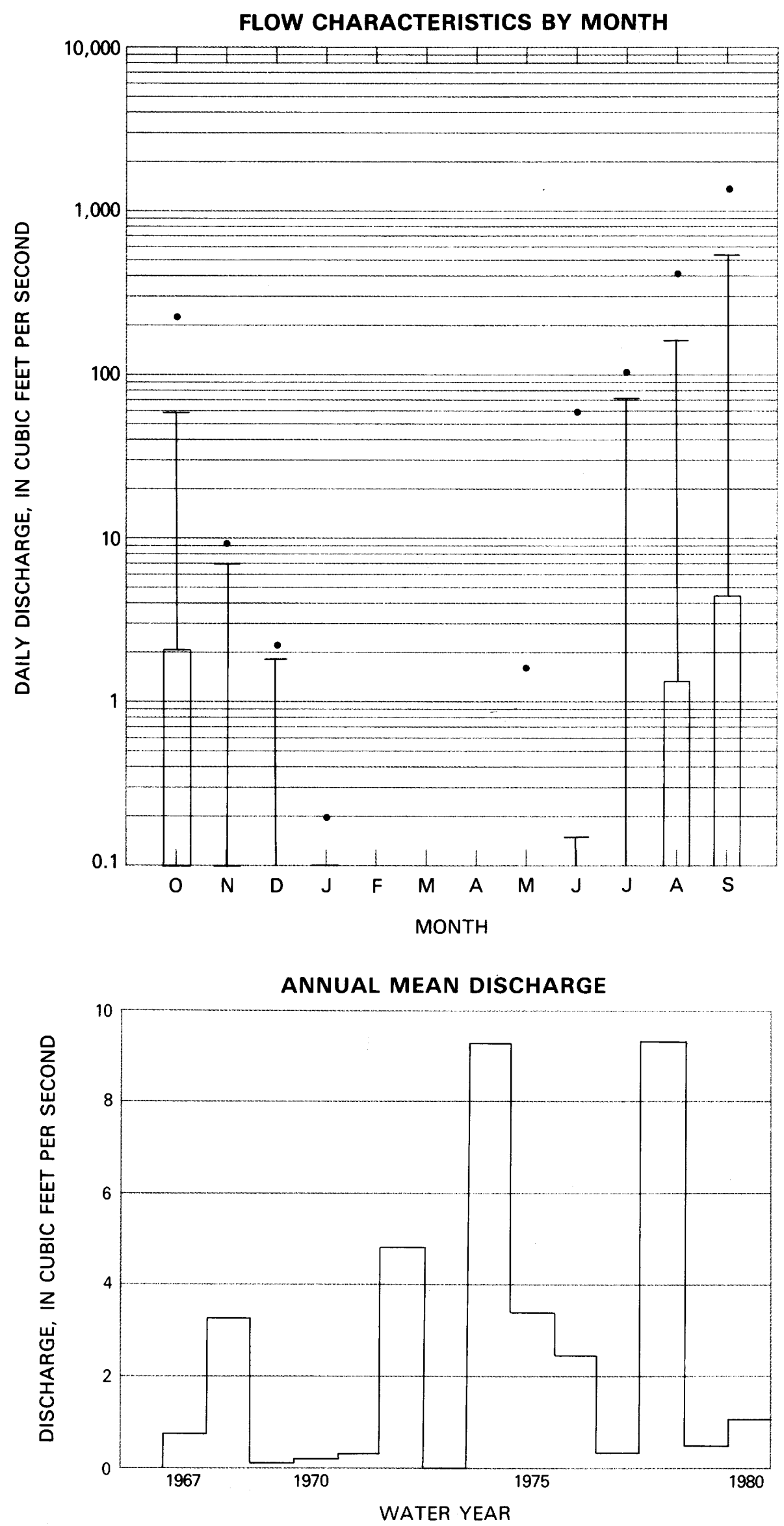
Station 51. - South Fork Rocky Creek near Briggs, TX (08103900)

Location: Lat $30^{\circ} 54^{\prime} 41^{\prime \prime}$, long $98^{\circ} 02^{\prime} 12^{\prime \prime}$, Burnet County, 7 mi west of Briggs.

Drainage area: $33.3 \mathrm{mi}^{2}$.

Topography: Rough topography. There are flat ridges and sloping canyon walls that in places rise on a $1.10 \mathrm{ft}$ slope for more than $100 \mathrm{ft}$ above the streambeds. Basin elevations range from 956 to about 1,150 ft. The stream slope is about $35 \mathrm{ft} / \mathrm{mi}$.

Rock type: The area is underlain by alternating beds of limestone and marl. The bedrock is covered in places by a thin mantle of black clay soil. There are alluvial deposits, less than $15 \mathrm{ft}$ thick, in the stream valley.

Vegetation: Approximately 80 percent of the basin has a grass cover and 2 percent contains crops. The remainder is wooded with oak, elm, hackberry, willow, and sycamore trees principally along the streams and valley floors. Dense brush occurs along the smaller tributaries.

Manmade influences: Some cultivated tracts have been returned to range land. Human habitation is sparse and insignificant. There are about 30 farm and ranchhouses and five county roads in the basin.

Period of record: April 1963 to September 1980.

Average discharge: $11.7 \mathrm{ft}^{3} / \mathrm{s}$.

Extremes: Maximum discharge, $31,200 \mathrm{ft}^{3} / \mathrm{s}$, June 19, 1976, gage height, $22.70 \mathrm{ft}$, from rating curve extended above $1,000 \mathrm{ft}^{3} / \mathrm{s}$ on basis of slope-area measurements of 3,580 and $8,510 \mathrm{ft}^{3} / \mathrm{s}$ and conveyance-slope study; no flow for many days each year for 1963-74 and 1976-80. Maximum stage since at least 1904, $22.70 \mathrm{ft}$, June 19, 1976.

Serial correlation coefficient for annual mean discharges: -0.135 .

Kendall's tau correlation coefficient for annual mean discharges: 0.059.

\begin{tabular}{|c|rrrr|}
\hline \multicolumn{5}{|c|}{ FLOOD FREQUENCY } \\
\hline \multicolumn{4}{|c|}{$\begin{array}{c}\text { Peak discharge, in cubic feet per second, for } \\
\text { indicated recurrence interval, in years }\end{array}$} \\
\hline $\begin{array}{c}\text { R. I. } \\
\text { Discharge }\end{array}$ & 2 & 5 & 10 & 25 \\
\hline
\end{tabular}

Standard Deviation (logs): 0.708

Skewness Coefficient (logs): -0.686

\begin{tabular}{|c|c|c|c|c|}
\hline \multicolumn{5}{|c|}{ LOW-FLOW FREQUENCY } \\
\hline $\begin{array}{l}\text { Consecutive } \\
\text { day period }\end{array}$ & \multicolumn{4}{|c|}{$\begin{array}{l}\text { Discharge, in cubic feet per second for } \\
\text { indicated recurrence interval, in years }\end{array}$} \\
\hline & 2 & 5 & 10 & 20 \\
\hline $\begin{array}{r}7 \\
14 \\
30 \\
60 \\
90\end{array}$ & & \multicolumn{3}{|c|}{$\begin{array}{l}\text { Long periods of no } \\
\text { flow for most years. }\end{array}$} \\
\hline
\end{tabular}

\section{FLOW DURATION}

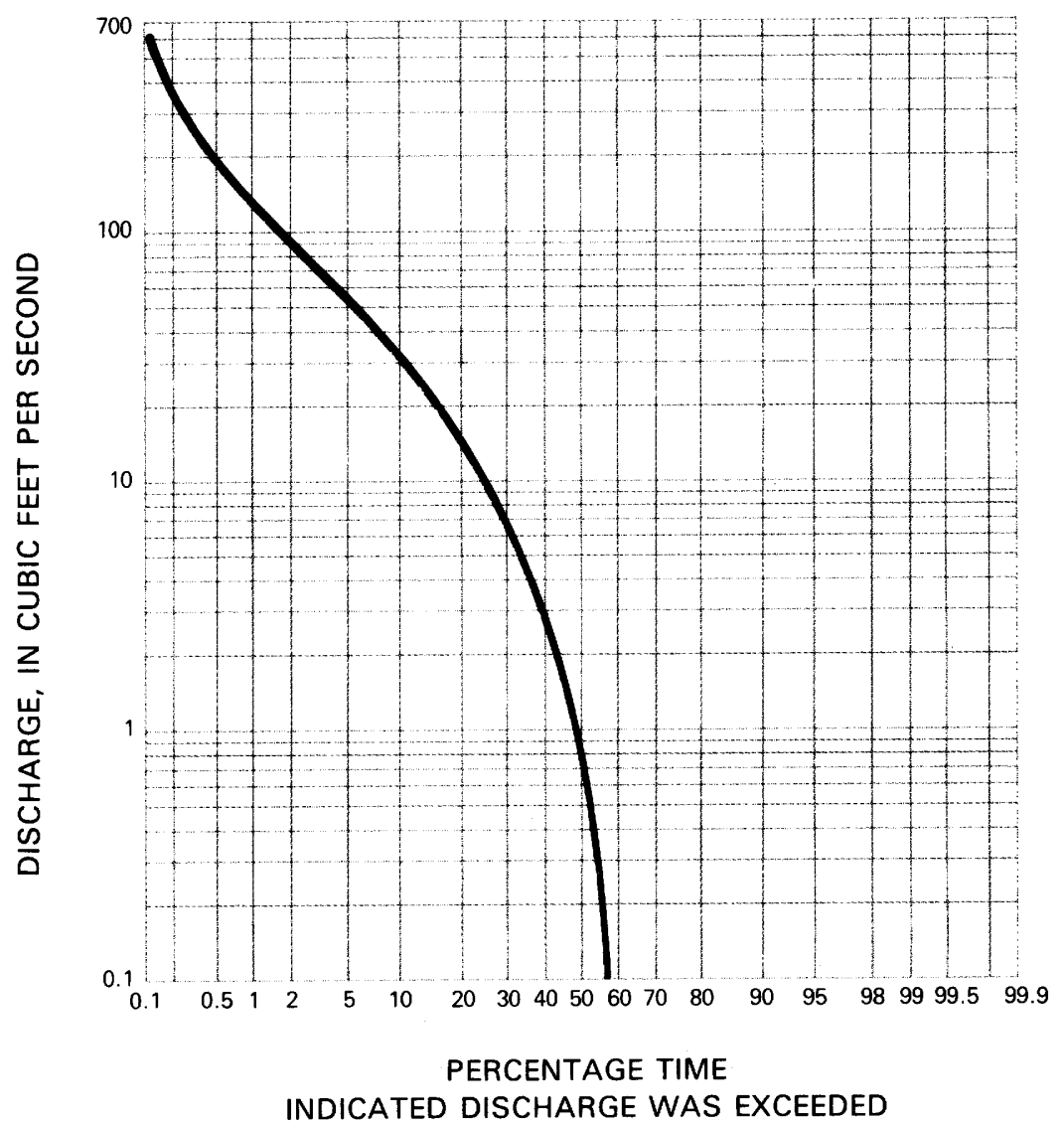



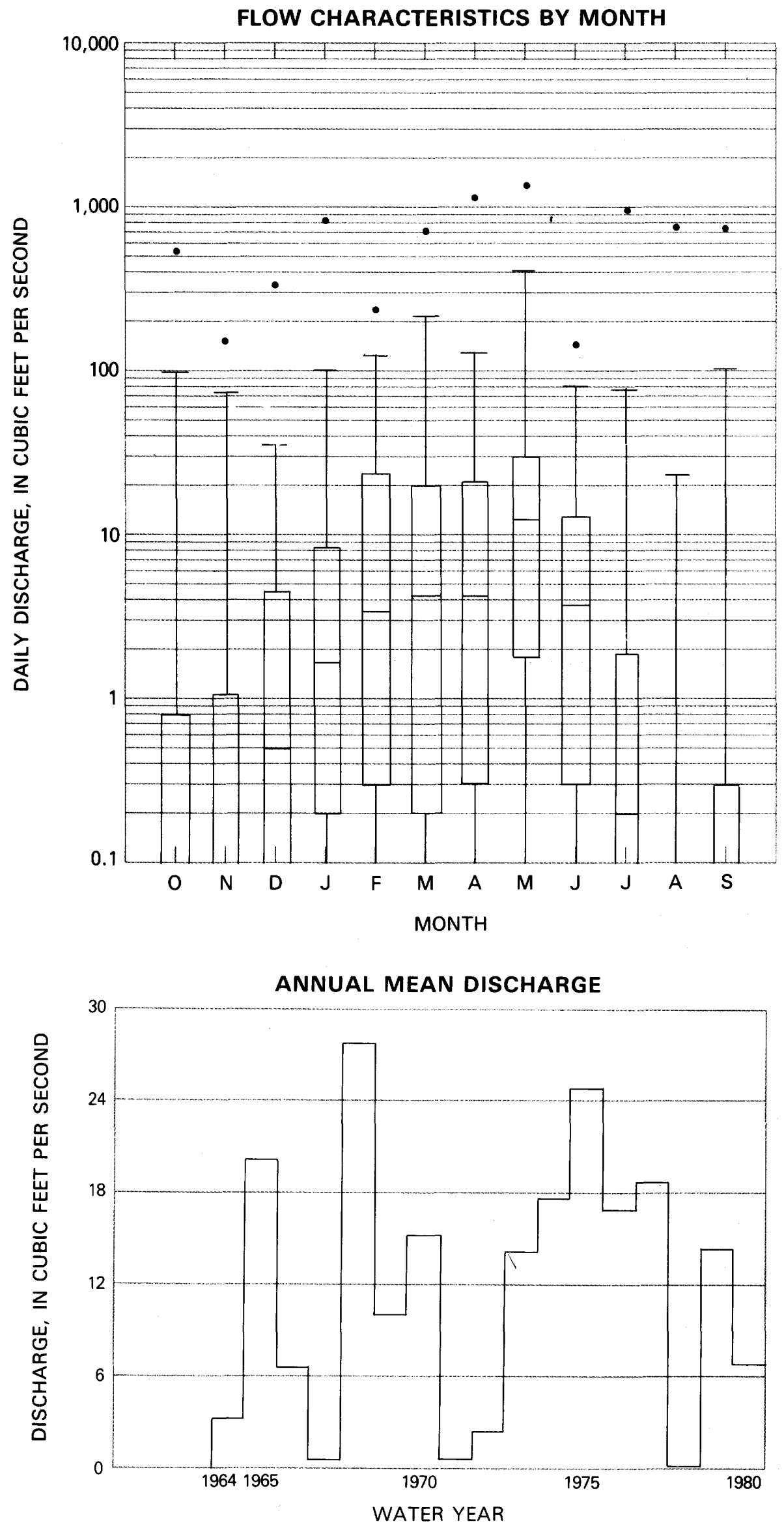
Location: Lat $40^{\circ} 46^{\prime} 48^{\prime \prime}$, long $111^{\circ} 48^{\prime} 19^{\prime \prime}$, Salt Lake County, 1.7 mi northeast of Fort Douglas and 4.7 mi east of Salt Lake City post office.

Drainage area: $7.25 \mathrm{mi}^{2}$.

Topography: Mountainous. Slopes are steep and have few rock outcrops. Basin elevations range from 5,400 to 8,240 $\mathrm{ft}$. The slope of the main stream is about $250-300 \mathrm{ft} / \mathrm{mi}$.

Rock type: The basin is underlain by southeastward-dipping beds of limestone, shale, and sandstone. Alluvium occurs along the streams but is only a few feet thick in most places.

Vegetation: The basin is thickly covered with oak brush, a few scattered clumps of evergreens, and a few small clumps of aspen. A thick growth of weeds, willows, and small maples inhabit the streambanks.

Manmade influences: The watershed is preserved to furnish water for Fort Douglas. Red Butte Reservoir (capacity 430 acre-feet) is just downstream from the gage. A fire-control road, one cabin, and a rock quarry, no longer used, are in the basin. Logging is nil and grazing is insignificant. Mud slides in 1975 are hydrologically insignificant.

Period of record: October 1963 to September 1980.

Average discharge: $4.1 \mathrm{ft}^{3} / \mathrm{s}$.

Extremes: Maximum discharge, $60 \mathrm{ft}{ }^{3} / \mathrm{s}$, May 18, 1975, gage height, $3.50 \mathrm{ft}$; minimum, $0.23 \mathrm{ft}^{3} / \mathrm{s}$, December $22,1976$.

Serial correlation coefficient for annual mean discharges: 0.218.

Kendall's tau correlation coefficient for annual mean discharges: 0.103.

\begin{tabular}{|c|cccc|}
\hline \multicolumn{5}{|c|}{ FLOOD FREQUENCY } \\
\hline \multicolumn{4}{|c|}{$\begin{array}{c}\text { Peak discharge, in cubic feet per second, for } \\
\text { indicated recurrence interval, in years }\end{array}$} \\
\hline R. I. & 2 & 5 & 10 & 25 \\
Discharge & 16.4 & 27.7 & 36.3 & 48.3 \\
\hline
\end{tabular}

Standard Deviation (logs): 0.271

Skewness Coefficient (logs): -0.043

\begin{tabular}{|c|cccc|}
\hline \multicolumn{5}{|c|}{ LOW-FLOW FREQUENCY } \\
\hline $\begin{array}{c}\text { Consecutive } \\
\text { day period }\end{array}$ & \multicolumn{3}{|c|}{$\begin{array}{l}\text { Discharge, in cubic feet per second for } \\
\text { indicated recurrence interval, in years }\end{array}$} \\
\hline & 2 & 5 & 10 & 20 \\
\cline { 2 - 5 } 7 & 1.5 & 1.1 & 1.0 & 0.8 \\
14 & 1.5 & 1.2 & 1.0 & 0.9 \\
30 & 1.6 & 1.2 & 1.1 & 0.9 \\
60 & 1.7 & 1.3 & 1.1 & 1.0 \\
90 & 1.8 & 1.4 & 1.2 & 1.1 \\
\hline
\end{tabular}

\section{FLOW DURATION}

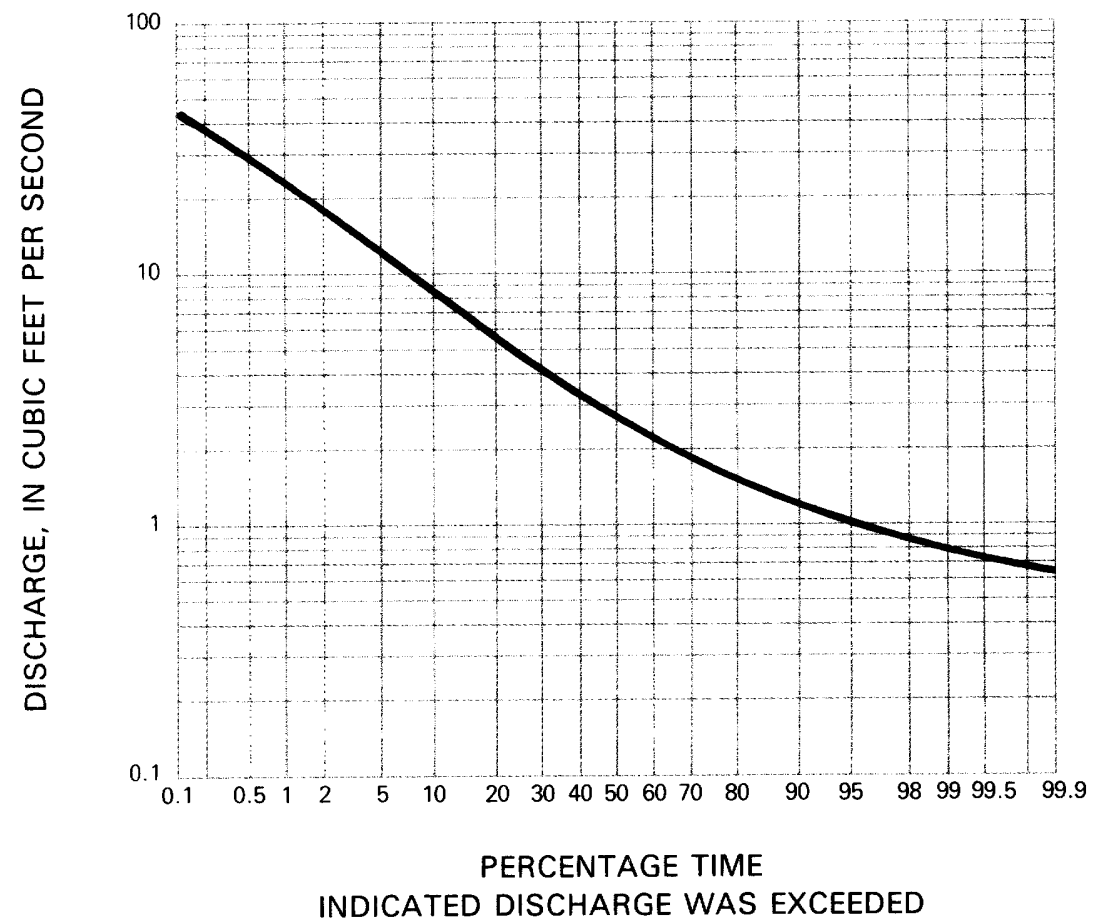


111

FLOW CHARACTERISTICS BY MONTH

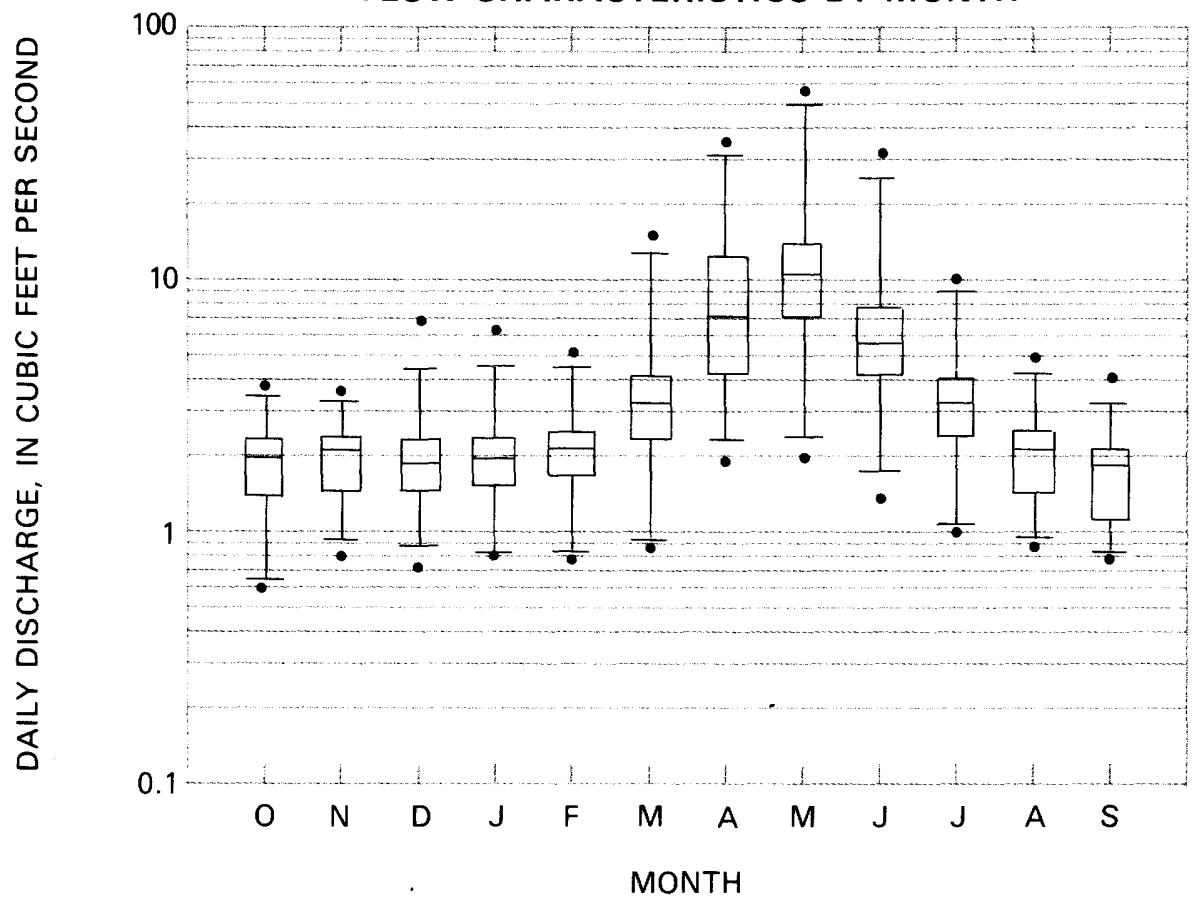

ANNUAL MEAN DISCHARGE

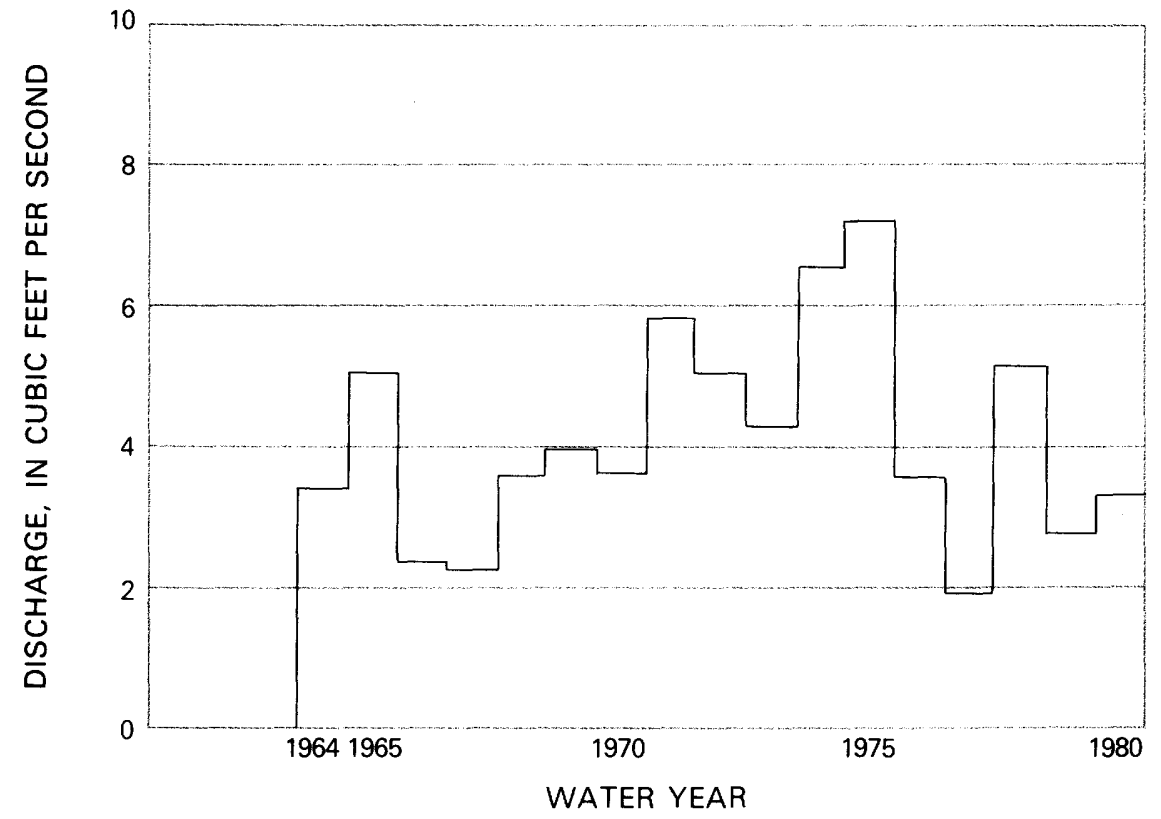


Station 53. - Holiday Creek near Andersonville, VA (02038850)

Location: Lat $37^{\circ} 24^{\prime} 55^{\prime \prime}$, long $78^{\circ} 38^{\prime} 10^{\prime \prime}$, Appomattox County, 5.2 mi southwest of Andersonville.

Drainage area: $8.53 \mathrm{mi}^{2}$.

Topography: Rolling hills. The general elevation of the divide is about $700 \mathrm{ft}$. Basin elevations range from 475 to 920 $\mathrm{ft}$. The slope of the main stream is about $60 \mathrm{ft} / \mathrm{mi}$.

Rock type: The basin is underlain by metamorphosed sedimentary rocks, primarily quartzite, kyanite schist, and shelton granite gneiss.

Vegetation: A managed hardwood forest covers most of the basin. A few stands of pine have been recently planted.

Manmade influences: The basin is almost wholly within the Appomattox-Buckingham State Forest. There have been cutting, thinning, and planting operations. Several roads and fire trails traverse the basin.

Period of record: April 1966 to September 1980.

Average discharge: $9.85 \mathrm{ft}^{3} / \mathrm{s}$.

Extremes: Maximum discharge, 9,640 ft $\mathrm{ft}^{3} / \mathrm{s}$, June 21, 1972, gage height, $14.64 \mathrm{ft}$, from high-water mark in gage house, from rating curve extended above $4,200 \mathrm{ft}^{3} / \mathrm{s}$ on basis of slope-area measurement of peak flow; minimum, $0.10 \mathrm{ft}^{3} / \mathrm{s}$, September 11, 12, 1966; minimum gage height, $0.75 \mathrm{ft}$, July 28,1966.

Serial correlation coefficient for annual mean discharges: 0.621 .

Kendall's tau correlation coefficient for annual mean discharges: 0.231 .

\begin{tabular}{|c|rrrr|}
\hline \multicolumn{5}{|c|}{ FLOOD FREQUENCY } \\
\hline \multicolumn{4}{|c|}{ Peak discharge, in cubic feet per second, for } \\
indicated recurrence interval, in years \\
\hline R. I. & 2 & 5 & 10 & 25 \\
Discharge & 569 & 1,870 & 3,820 & 8,770 \\
\hline
\end{tabular}

Standard Deviation (logs): 0.571

Skewness Coefficient (logs): 0.697

\begin{tabular}{|l|cccc|}
\hline \multicolumn{5}{|c|}{ LOW-FLOW FREQUENCY } \\
\hline $\begin{array}{l}\text { Consecutive } \\
\text { day period }\end{array}$ & \multicolumn{3}{|c|}{$\begin{array}{l}\text { Discharge, in cubic feet per second for } \\
\text { indicated recurrence interval, in years }\end{array}$} \\
\hline & 2 & 5 & 10 & 20 \\
\cline { 2 - 5 } 7 & 1.8 & 1.0 & 0.5 & 0.1 \\
14 & 2.0 & 1.1 & 0.6 & 0.2 \\
30 & 2.3 & 1.2 & 0.8 & 0.5 \\
60 & 2.7 & 1.5 & 1.0 & 0.7 \\
90 & 3.3 & 1.7 & 1.2 & 0.8 \\
\hline
\end{tabular}

\section{FLOW DURATION}

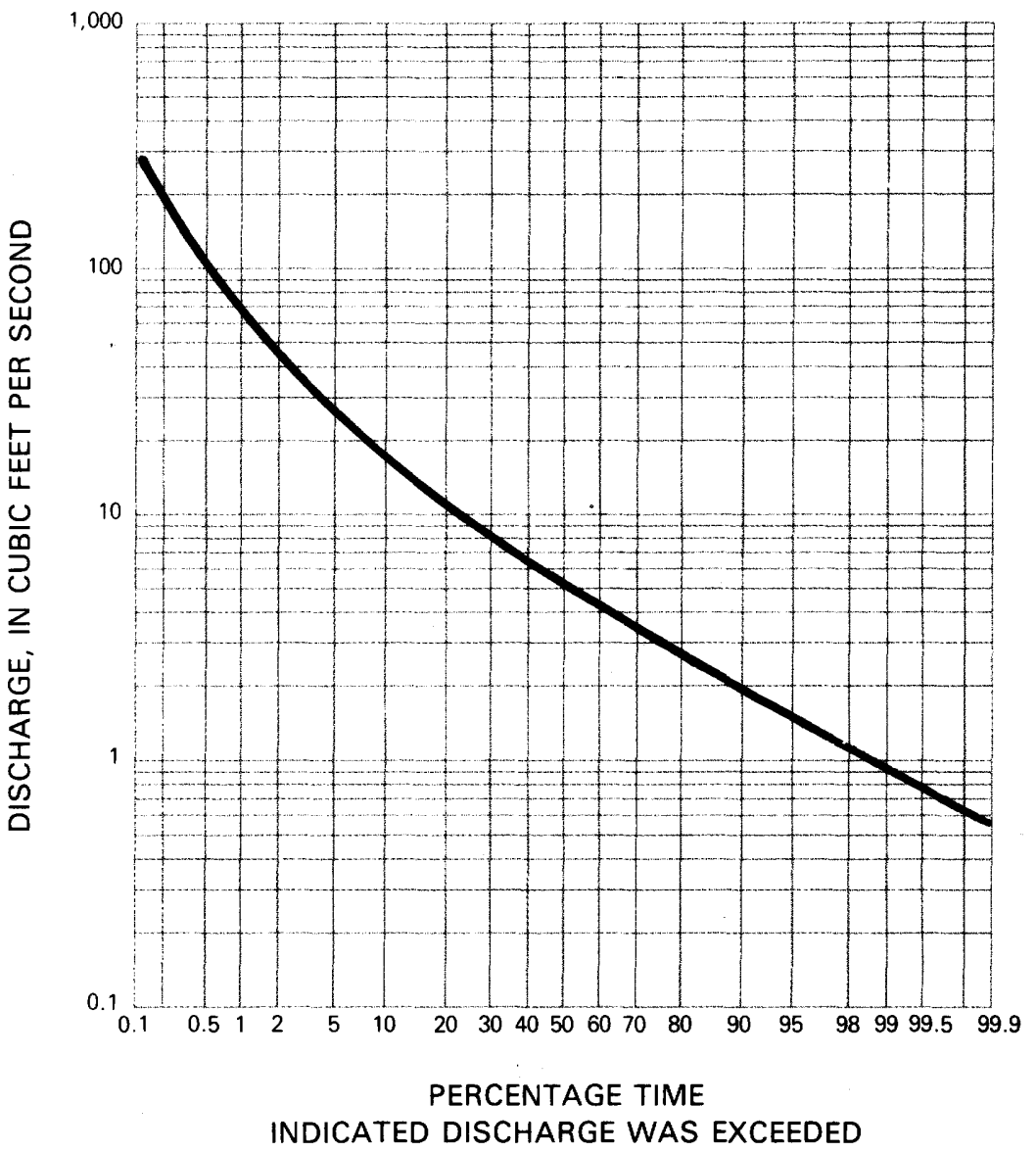



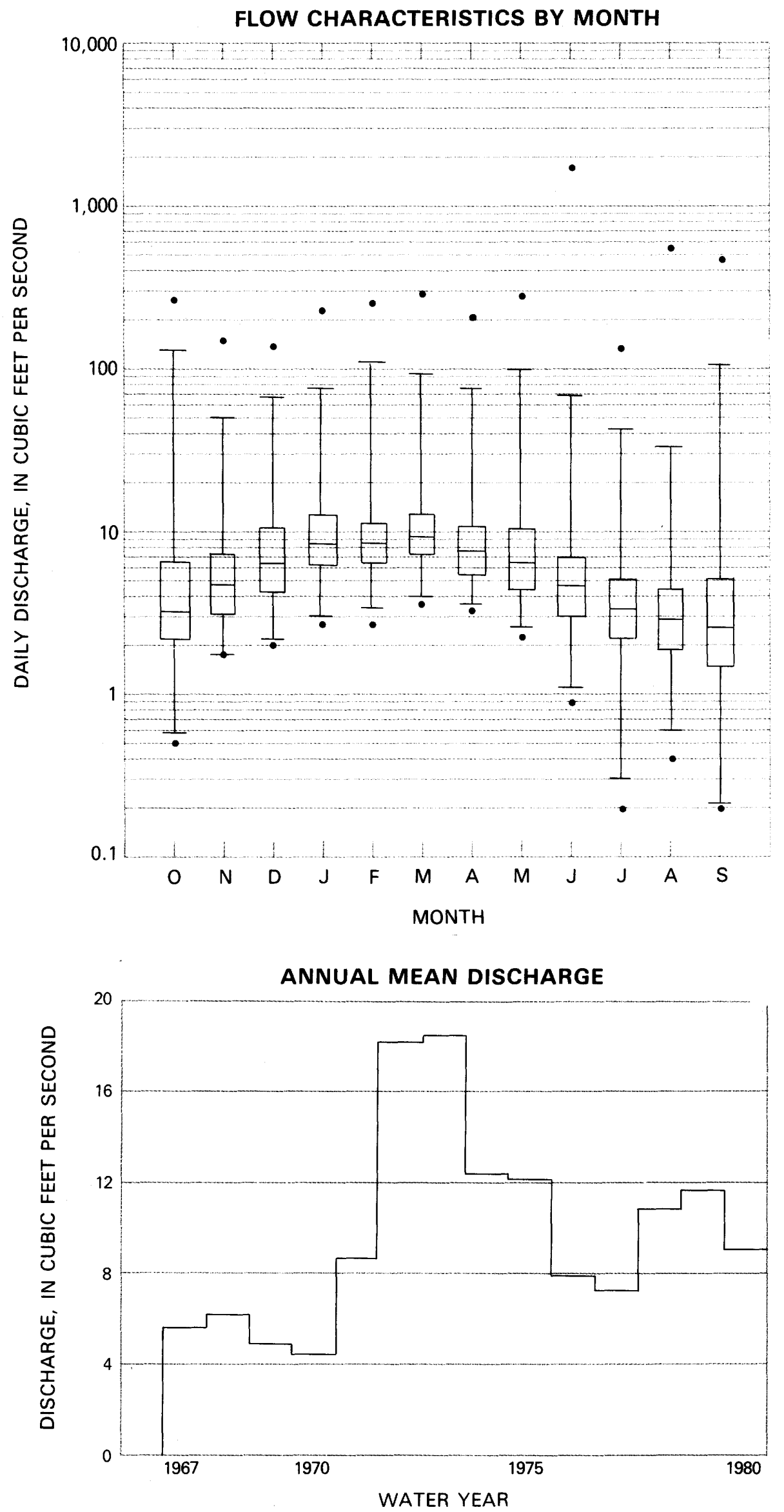
Station 54.-Andrews Creek near Mazama, WA (12447390)

Location: Lat $48^{\circ} 49^{\prime} 23^{\prime \prime}$, long $120^{\circ} 08^{\prime} 41^{\prime \prime}$, Okanogan County, 20 mi northeast of Mazama.

Drainage area: $22.1 \mathrm{mi}^{2}$.

Topography: Rugged mountains. Basin elevations range from 4,300 to 8,700 ft. The slope of the main stream is steep and consists of a continuous series of rapids and small waterfalls.

Rock type: Largely granite rocks overlain by fluvial glacial sediment.

Vegetation: The basin is covered with a moderately dense forest of fir, cedar, hemlock, and undergrowth.

Manmade influences: The entire drainage is within the Pasayten Wilderness Area. One main and three intermediate forest trails traverse the basin.

Period of record: June 1968 to September 1980.

Average discharge: $33.1 \mathrm{ft}^{3} / \mathrm{s}$.

Extremes: Maximum discharge, 1,120 ft $3 / \mathrm{s}$, June 10, 1972, gage height, $4.00 \mathrm{ft}$, from rating curve extended above 440 $\mathrm{ft}^{3} / \mathrm{s}$; minimum, $1.2 \mathrm{ft}^{3} / \mathrm{s}$, November 4, 1968, November 20, 1970, April 7, 1975; minimum gage height, $0.27 \mathrm{ft}$, March 25-29, April 6, 7, 1975.

Serial correlation coefficient for annual mean discharges: -0.384 .

Kendall's tau correlation coefficient for annual mean discharges: -0.152 .

\begin{tabular}{|c|rrrr|}
\hline \multicolumn{5}{|c|}{ FLOOD FREQUENCY } \\
\hline \multicolumn{4}{|c|}{$\begin{array}{c}\text { Peak discharge, in cubic feet per second, for } \\
\text { indicated recurrence interval, in years }\end{array}$} \\
\hline $\begin{array}{c}\text { R. I. } \\
\text { Discharge }\end{array}$ & 2 & 5 & 10 & 25 \\
\hline
\end{tabular}

Standard Deviation (logs): 0.234

Skewness Coefficient (logs): 0.205

\begin{tabular}{|c|cccc|}
\hline \multicolumn{5}{|c|}{ LOW-FLOW FREQUENCY } \\
\hline $\begin{array}{c}\text { Consecutive } \\
\text { day period }\end{array}$ & \multicolumn{3}{|c|}{$\begin{array}{l}\text { Discharge, in cubic feet per second for } \\
\text { indicated recurrence interval, in years }\end{array}$} \\
\hline & 2 & 5 & 10 & 20 \\
\cline { 2 - 5 } 7 & 2.2 & 1.7 & 1.5 & 1.3 \\
14 & 2.4 & 1.8 & 1.6 & 1.4 \\
30 & 2.7 & 2.1 & 1.8 & 1.6 \\
60 & 2.9 & 2.3 & 2.1 & 1.9 \\
90 & 3.1 & 2.5 & 2.2 & 2.0 \\
\hline
\end{tabular}

FLOW DURATION

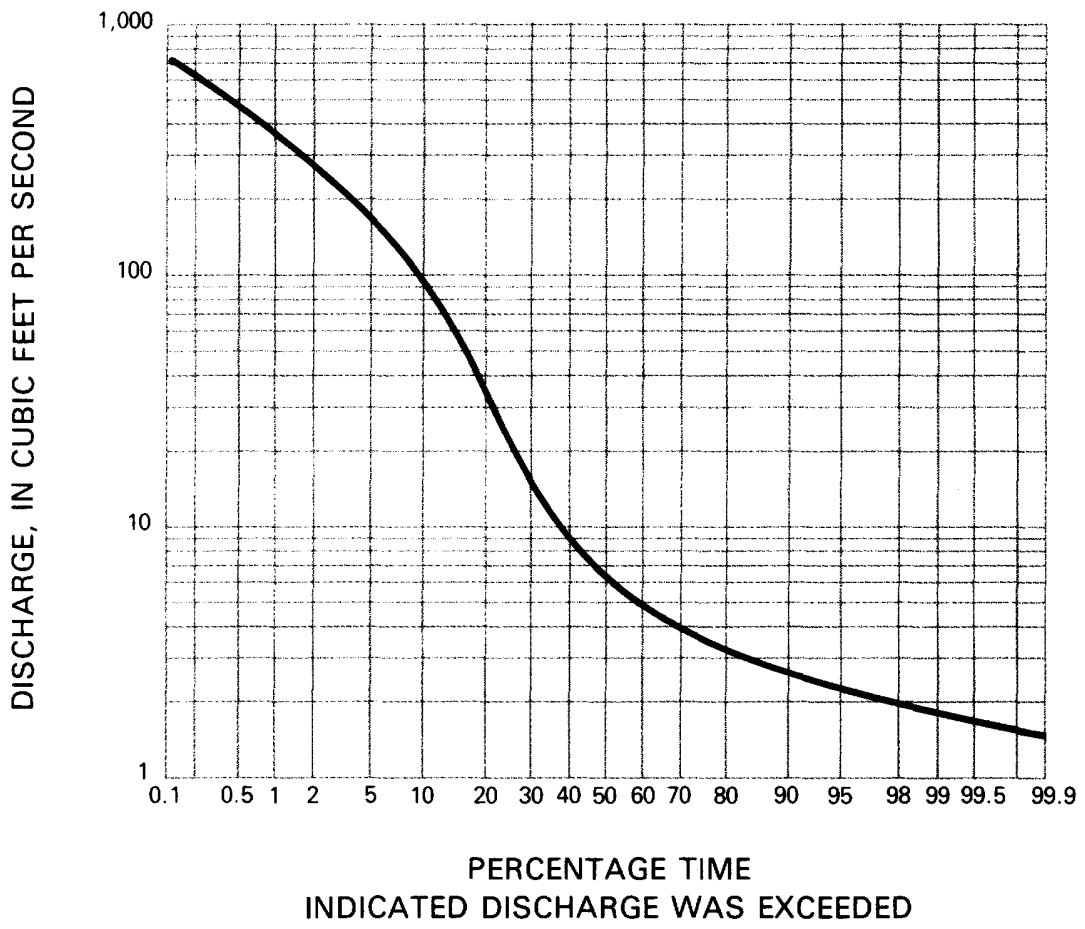



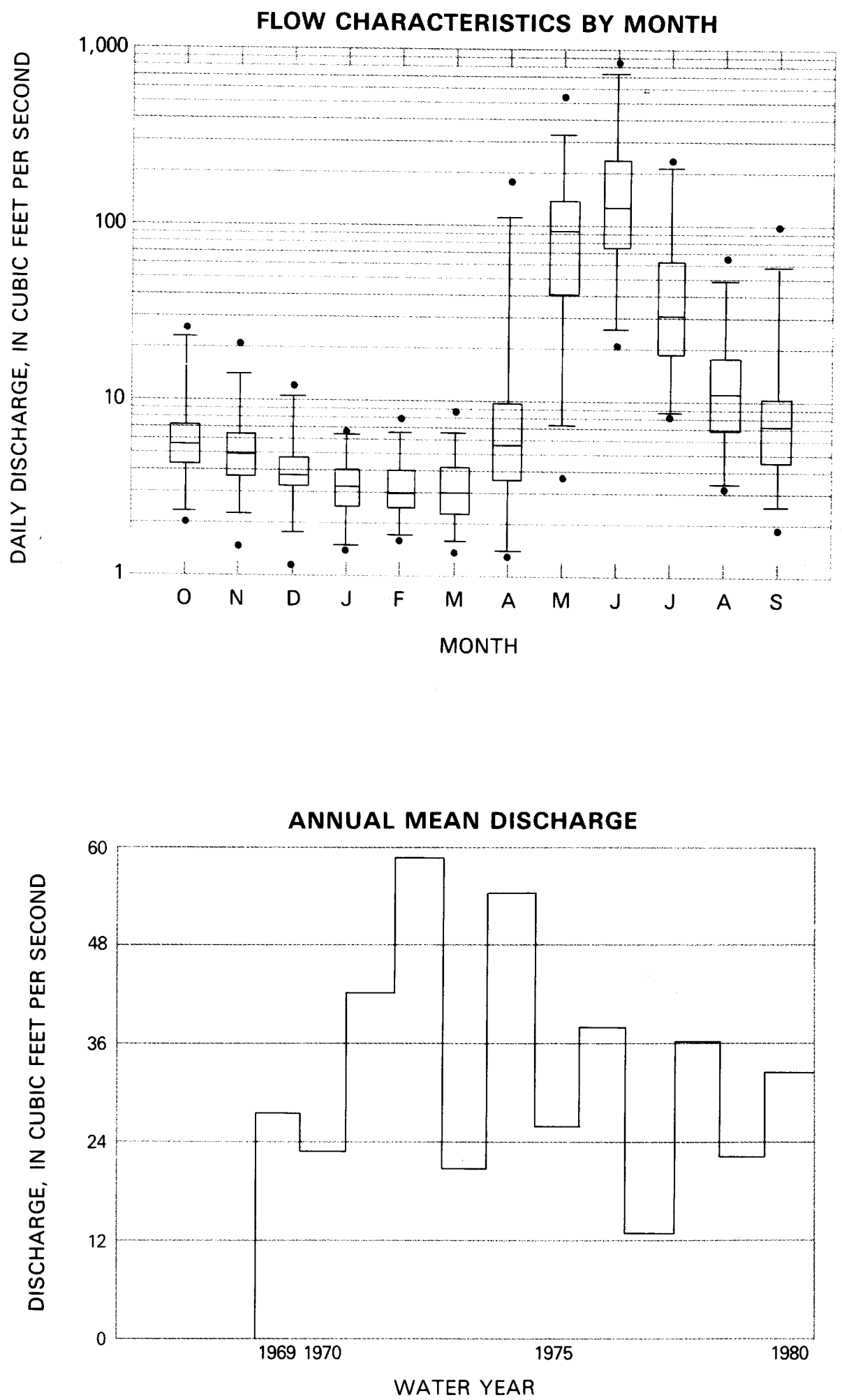
Station 55. - North Fork Quinault River near Amanda Park, WA (12039300)

Location: Lat $47^{\circ} 35^{\prime} 46^{\prime \prime}$, long $123^{\circ} 37^{\prime} 23^{\prime \prime}$, Jefferson County, 18 mi northeast of Amanda Park.

Drainage area: $74.1 \mathrm{mi}^{2}$.

Topography: Rugged mountains. Basin elevations range from 620 to $6,250 \mathrm{ft}$. The slope of the main stream is about $200 \mathrm{ft} / \mathrm{mi}$.

Rock type: Dark-gray massive or poorly bedded slate is overlain on the north side of the channel by glacial deposits and a thick mantle of soil.

Vegetation: Heavy to moderate stands of virgin hemlock, fir, spruce, and cedar grow to an elevation of about 3,500 $\mathrm{ft}$. Alpine-type growth occurs between 3,500 and $5,000 \mathrm{ft}$. Bare rock is predominant above $5,000 \mathrm{ft}$.

Manmade influences: The basin lies entirely within Olympic National Park and has been proposed for designation as wilderness under the terms of the Wilderness Act of 1964. Two trails traverse the basin, otherwise it is pristine.

Period of record: November 1964 to September 1980.

Average discharge: $865 \mathrm{ft}^{3} / \mathrm{s}$.

Extremes: Maximum discharge, 26,800 ft $3 / \mathrm{s}$, November 1, 1977, gage height, $13.76 \mathrm{ft}$, from rating curve extended above $4,200 \mathrm{ft}^{3} / \mathrm{s}$; minimum, $103 \mathrm{ft}^{3} / \mathrm{s}$, October 3, 1965; gage height, $1.93 \mathrm{ft}$.

Serial correlation coefficient for annual mean discharges: -0.481 .

Kendall's tau correlation coefficient for annual mean discharges: -0.143 .

\begin{tabular}{|c|rrrr|}
\hline \multicolumn{5}{|c|}{ FLOOD FREQUENCY } \\
\hline \multicolumn{4}{|c|}{$\begin{array}{l}\text { Peak discharge, in cubic feet per second, for } \\
\text { indicated recurrence interval, in years }\end{array}$} \\
\hline $\begin{array}{c}\text { R. I. } \\
\text { Discharge }\end{array}$ & 14,600 & 20,500 & 24,500 & 29,500 \\
\hline
\end{tabular}

Standard Deviation (logs): 0.177

Skewness Coefficient (logs): -0.027

\begin{tabular}{|c|cccc|}
\hline \multicolumn{5}{|c|}{ LOW-FLOW FREQUENCY } \\
\hline $\begin{array}{c}\text { Consecutive } \\
\text { day period }\end{array}$ & \multicolumn{3}{|c|}{$\begin{array}{l}\text { Discharge, in cubic feet per second for } \\
\text { indicated recurrence interval, in years }\end{array}$} \\
\hline & 2 & 5 & 10 & 20 \\
\cline { 2 - 5 } & 158 & 133 & 123 & 115 \\
7 & 174 & 145 & 133 & 123 \\
30 & 209 & 169 & 151 & 138 \\
60 & 290 & 231 & 205 & 185 \\
90 & 367 & 294 & 264 & 243 \\
\hline
\end{tabular}

\section{FLOW DURATION}

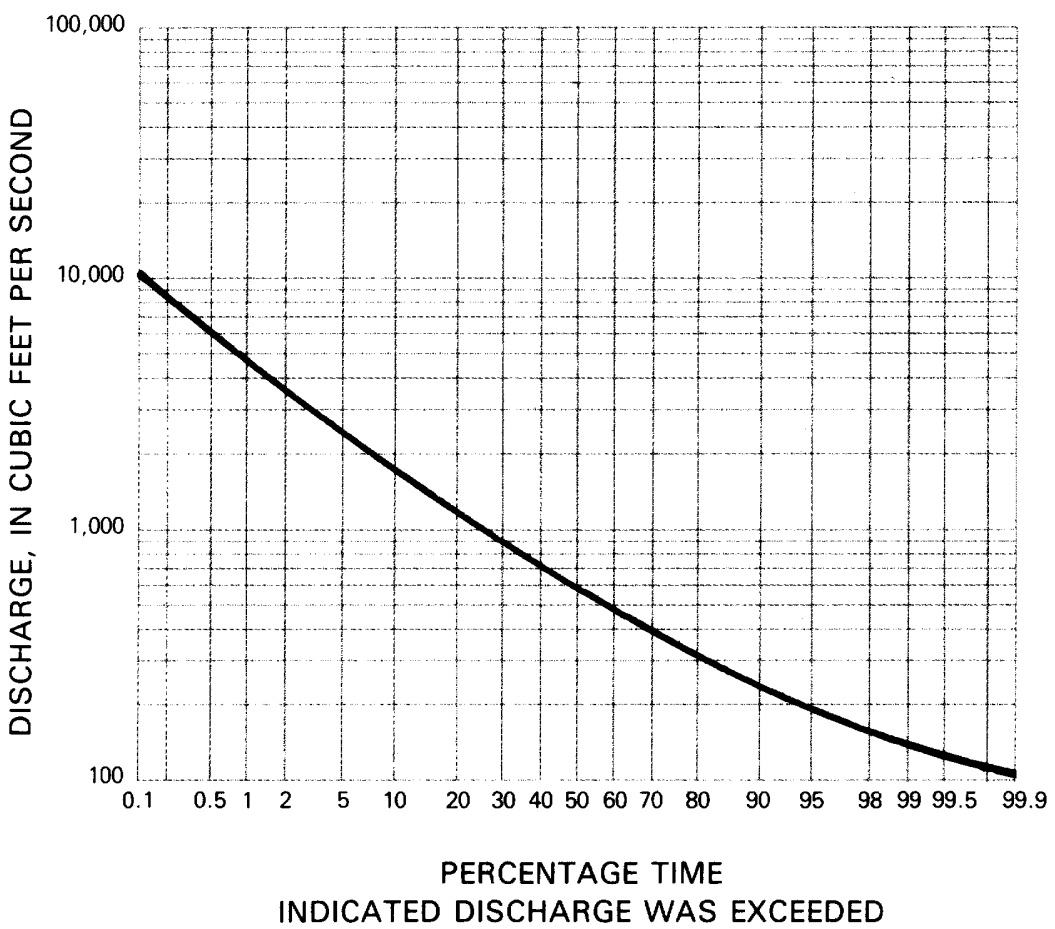



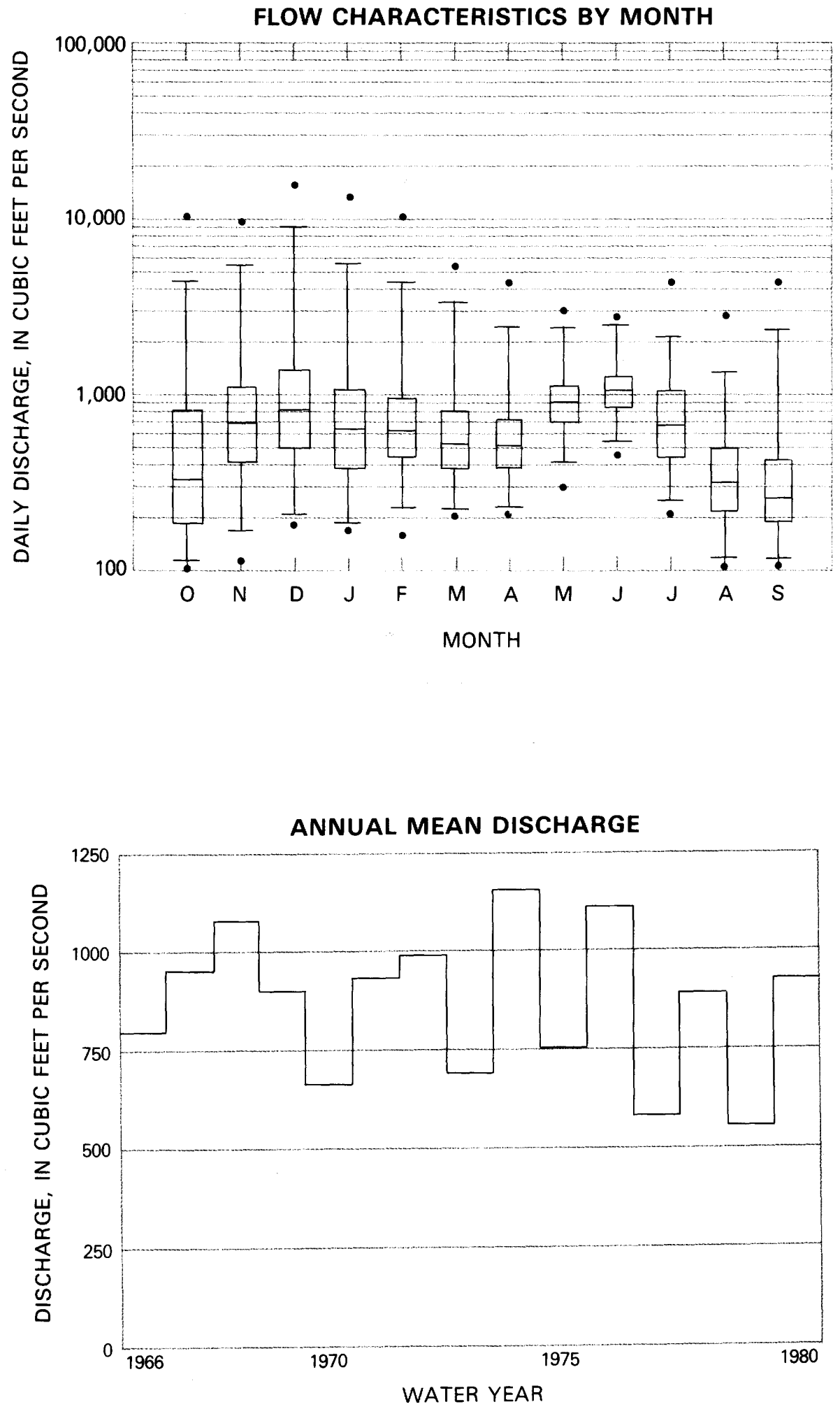
Location: Lat $45^{\circ} 45^{\prime} 49^{\prime \prime}$, long $88^{\circ} 27^{\prime} 47^{\prime \prime}$, Florence County, $20 \mathrm{ft}$ upstream from U.S. Forest Service Road 2159 , and $2.6 \mathrm{mi}$ northwest of Fence.

Drainage area: $139 \mathrm{mi}^{2}$.

Topography: Gently rolling terrain that has some flat terraces. Basin elevations range from 1,410 to 1,600 ft. The slope of the main stream is about $10 \mathrm{ft} / \mathrm{mi}$ and there are occasional riffles at rock outcrops.

Rock type: Glacial deposits are underlain by igneous and metamorphic crystalline rocks, generally granite, schist, and greenstone. The glacial drift ranges in thickness from 0 to $80 \mathrm{ft}$ and is primarily composed of outwash sand and sandy gravel.

Vegetation: Rather dense coniferous and deciduous forest covers about 95 percent of the basin. The forest is primarily made up of aspen, northern hardwoods, pine, and swamp trees. The remainder of the basin consists of scattered active or abandoned farms and the area in and around the community of Newald.

Manmade influences: Newald (population about 175), in the south-central part of the basin, has neither public watersupply nor public waste-disposal systems. A small amount of farming is practiced in the basin. Several roads traverse the basin. The Popple River basin is part of a State wild-river area.

Period of record: October 1963 to September 1980.

Average discharge: $124 \mathrm{ft}^{3} / \mathrm{s}$.

Extremes: Maximum discharge, 1,640 $\mathrm{ft}^{3} / \mathrm{s}$, April 25, 1979, gage height, $4.52 \mathrm{ft}$; minimum discharge, $5.9 \mathrm{ft}^{3} / \mathrm{s}, 0 \mathrm{ctober}$ 28,1976 , gage height, $0.75 \mathrm{ft}$, result of temporary storage from beaver dam.

Serial correlation coefficient for annual mean discharges: 0.111 .

Kendall's tau correlation coefficient for annual mean discharges: 0.081 .

\section{FLOW DURATION}

\begin{tabular}{|c|rrrr|}
\hline \multicolumn{5}{|c|}{ FLOOD FREQUENCY } \\
\hline \multicolumn{4}{|c|}{$\begin{array}{l}\text { Peak discharge, in cubic feet per second, for } \\
\text { indicated recurrence interval, in years }\end{array}$} \\
\hline \begin{tabular}{c|rrrr} 
R. I. \\
Discharge
\end{tabular} & 2 & 5 & 10 & 25 \\
\hline
\end{tabular}

Standard Deviation (logs): 0.162

Skewness Coefficient (logs): 0.192

\begin{tabular}{|c|cccc|}
\hline \multicolumn{4}{|c|}{ LOW-FLOW FREQUENCY } \\
\hline $\begin{array}{l}\text { Consecutive } \\
\text { day period }\end{array}$ & \multicolumn{3}{|c|}{$\begin{array}{l}\text { Discharge, in cubic feet per second for } \\
\text { indicated recurrence interval, in years }\end{array}$} \\
\hline & 2 & 5 & 10 & 20 \\
\cline { 2 - 5 } 7 & 31 & 24 & 21 & 19 \\
14 & 32 & 26 & 23 & 21 \\
30 & 35 & 27 & 24 & 22 \\
60 & 40 & 32 & 30 & 28 \\
90 & 44 & 35 & 32 & 30 \\
\hline
\end{tabular}

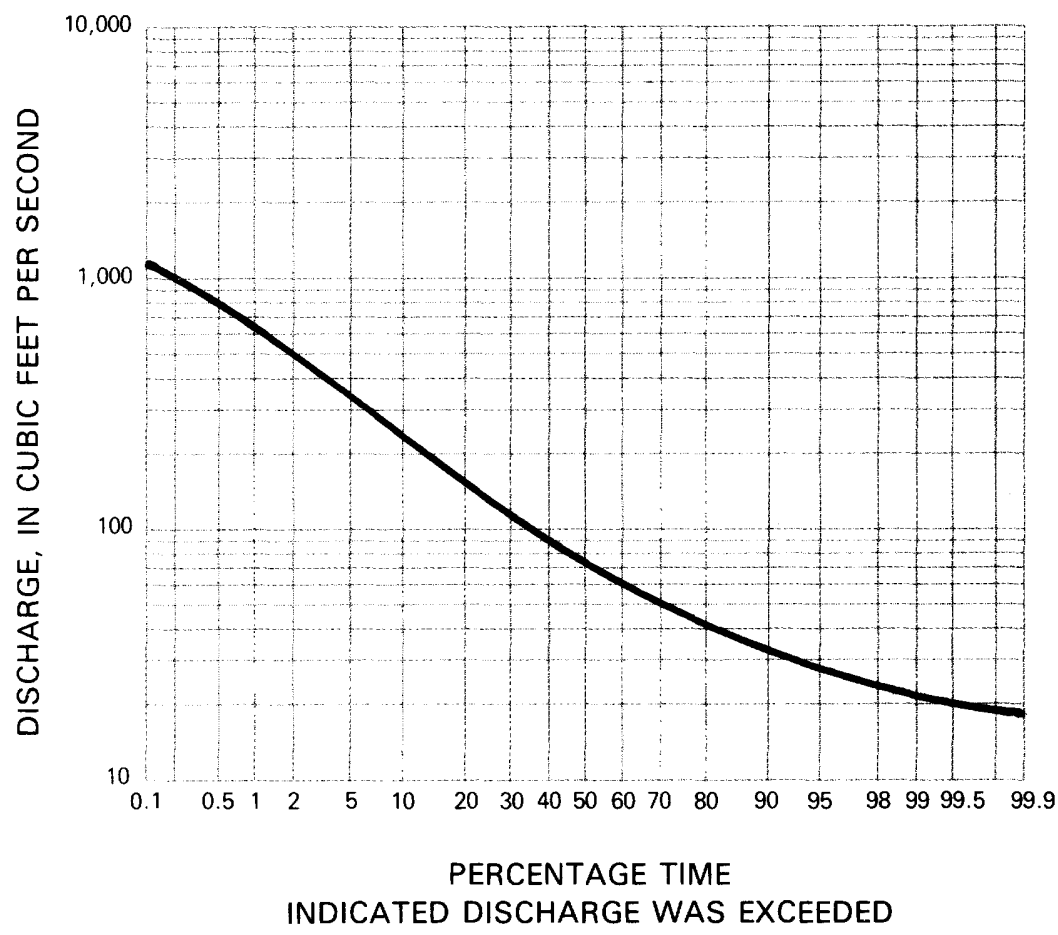



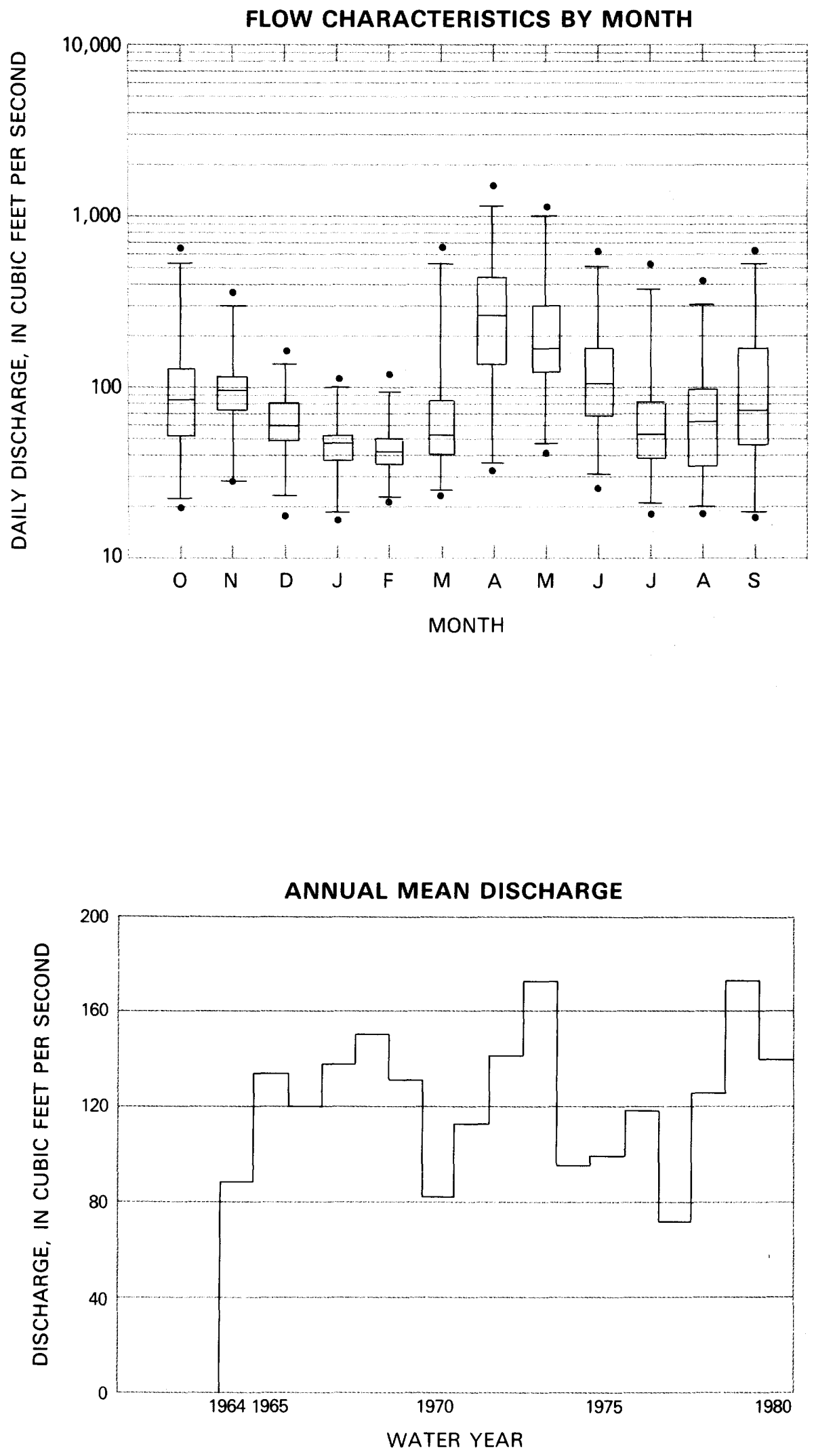
Station 57.-Cache Creek near Jackson, WY (13018300)

Location: Lat $43^{\circ} 27^{\prime} 08^{\prime \prime}$, long $110^{\circ} 42^{\prime} 12^{\prime \prime}$, Teton County, 2.4 mi southeast of Jackson.

Drainage area: $10.6 \mathrm{mi}^{2}$.

Topography: Mountains and canyons. The general divide elevation is about $9,000 \mathrm{ft}$. Basin elevations range from 6,800 to $10,300 \mathrm{ft}$. The slope of the main stream is about $300 \mathrm{ft} / \mathrm{mi}$.

Rock type: Sandstone and shale are covered with alluvium in the lower valleys.

Vegetation: Forests of pine, fir, and spruce cover about 80 percent of the north slopes and about 50 percent of the south slopes. Grass and brush covers the remaining area up to timberline.

Manmade influences: The area is used seasonally for recreation. One road enters the basin and one pack trail traverses the basin.

Period of record: June 1962 to September 1980.

Average discharge: $13.6 \mathrm{ft}^{3} / \mathrm{s}$.

Extremes: Maximum discharge, $225 \mathrm{ft}^{3} / \mathrm{s}$, June 24, 1971, gage height, $3.90 \mathrm{ft}$; maximum gage height, $3.97 \mathrm{ft}$, June 7, 1972; minimum daily discharge, $2.1 \mathrm{ft} 3 / \mathrm{s}$, January $1,1978$.

Serial correlation coefficient for annual mean discharges: -0.103 .

Kendall's tau correlation coefficient for annual mean discharges: -0.059 .

\begin{tabular}{|c|c|c|c|c|}
\hline \multicolumn{5}{|c|}{ FLOOD FREQUENCY } \\
\hline \multicolumn{5}{|c|}{$\begin{array}{l}\text { Peak discharge, in cubic feet per second, for } \\
\text { indicated recurrence interval, in years }\end{array}$} \\
\hline R. I. & 2 & 5 & 10 & 25 \\
\hline Discharge & 84 & 123 & 152 & 190 \\
\hline
\end{tabular}

Standard Deviation (logs): 0.193

Skewness Coefficient (logs): 0.143

\begin{tabular}{|c|cccc|}
\hline \multicolumn{5}{|c|}{ LOW-FLOW FREQUENCY } \\
\hline $\begin{array}{c}\text { Consecutive } \\
\text { day period }\end{array}$ & \multicolumn{3}{|c|}{$\begin{array}{l}\text { Discharge, in cubic feet per second for } \\
\text { indicated recurrence interval, in years }\end{array}$} \\
\hline & 2 & 5 & 10 & 20 \\
\cline { 2 - 5 } & 3.4 & 3.0 & 2.7 & 2.5 \\
7 & 3.5 & 3.1 & 2.8 & 2.6 \\
30 & 3.7 & 3.2 & 3.0 & 2.7 \\
60 & 4.0 & 3.5 & 3.2 & 2.9 \\
90 & 4.2 & 3.7 & 3.3 & 3.1 \\
\hline
\end{tabular}

FLOW DURATION

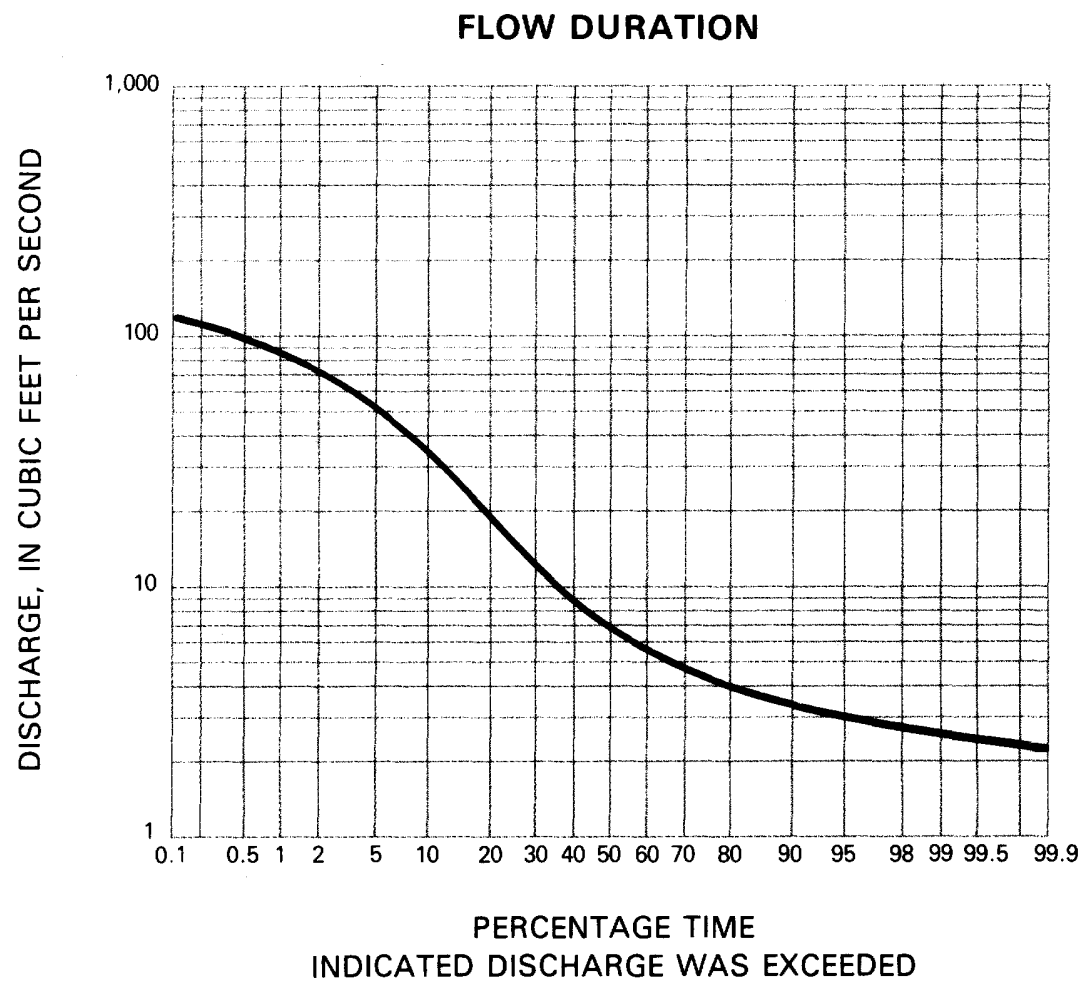



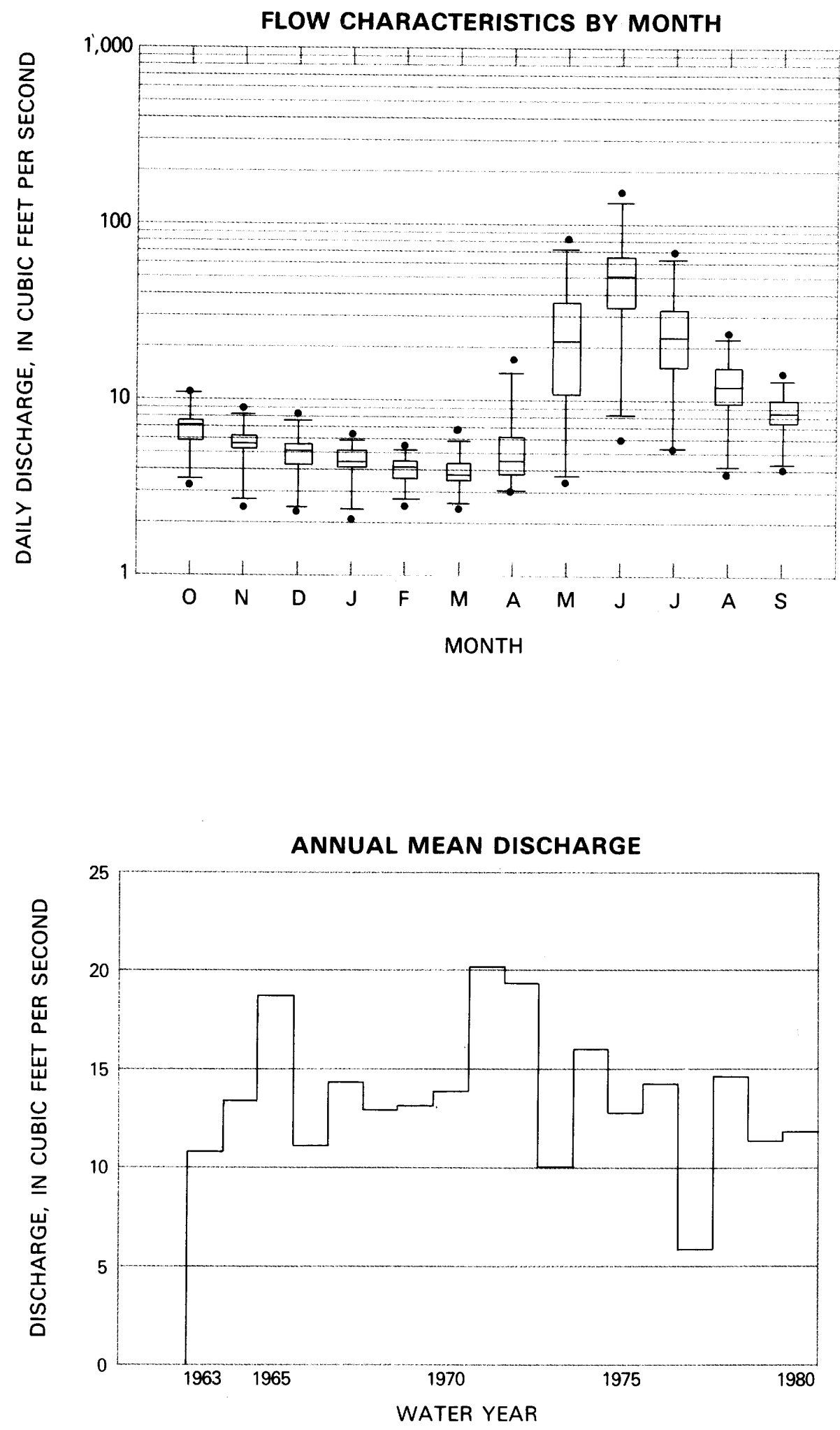
Station 58.-Encampment River near Encampment, WY (06623800)

Location: Lat $41^{\circ} 01^{\prime} 25^{\prime \prime}$, long $106^{\circ} 49^{\prime} 27^{\prime \prime}$, Carbon County, 13 mi south of Encampment.

Drainage area: $72.7 \mathrm{mi}^{2}$.

Topography: Mountainous. The general divide elevation is about $10,000 \mathrm{ft}$. Basin elevations range from 8,270 to more than $11,400 \mathrm{ft}$. The slope of the main stream is about $100 \mathrm{ft} / \mathrm{mi}$.

Rock type: Crystalline rocks, chiefly granite, and lesser amounts of metasedimentary rocks are in the basin.

Vegetation: Most of the basin is covered with forest consisting primarily of lodgepole pine, fir, and spruce. Part of the basin is bare ground above timberline. The remainder of the basin consists of grass-covered openings and meadows in the valleys.

Manmade influences: The basin is used for seasonal recreation. Pack trails traverse the basin. There is commercial logging in the headwaters of a tributary, Damfino Creek.

Period of record: October 1964 to September 1980.

Average discharge: $114 \mathrm{ft}^{3} / \mathrm{s}$.

Extremes: Maximum discharge, 1,680 ft $3 / \mathrm{s}$, about June 13, 1965 (gage height not determined), from slope-area measurement of peak floe; minimum daily, $9.5 \mathrm{ft}^{3} / \mathrm{s}$, December 31, 1968.

Serial correlation coefficient for annual mean discharges: 0.013 .

Kendall's tau correlation coefficient for annual mean discharges: 0.233.

\begin{tabular}{|c|rrrr|}
\hline \multicolumn{5}{|c|}{ FLOOD FREQUENCY } \\
\hline \multicolumn{4}{|c|}{ Peak discharge, in cubic feet per second, for } \\
indicated recurrence interval, in years \\
\hline R. I. & 2 & 5 & 10 & 25 \\
Discharge & 1,020 & 1,290 & 1,450 & 1,640 \\
\hline
\end{tabular}

Standard Deviation (logs): 0.127

Skewness Coefficient (logs): -0.218

\begin{tabular}{|c|cccc|}
\hline \multicolumn{4}{|c|}{ LOW-FLOW FREQUENCY } \\
\hline $\begin{array}{c}\text { Consecutive } \\
\text { day period }\end{array}$ & \multicolumn{3}{|c|}{$\begin{array}{l}\text { Discharge, in cubic feet per second for } \\
\text { indicated recurrence interval, in years }\end{array}$} \\
\hline & 2 & 5 & 10 & 20 \\
\cline { 2 - 5 } 7 & 14.7 & 12.0 & 10.9 & 10.1 \\
14 & 15.1 & 12.3 & 11.0 & 10.2 \\
30 & 16.0 & 13.1 & 11.7 & 10.7 \\
60 & 16.8 & 13.7 & 12.3 & 11.3 \\
90 & 17.6 & 14.4 & 12.9 & 11.8 \\
\hline
\end{tabular}

FLOW DURATION

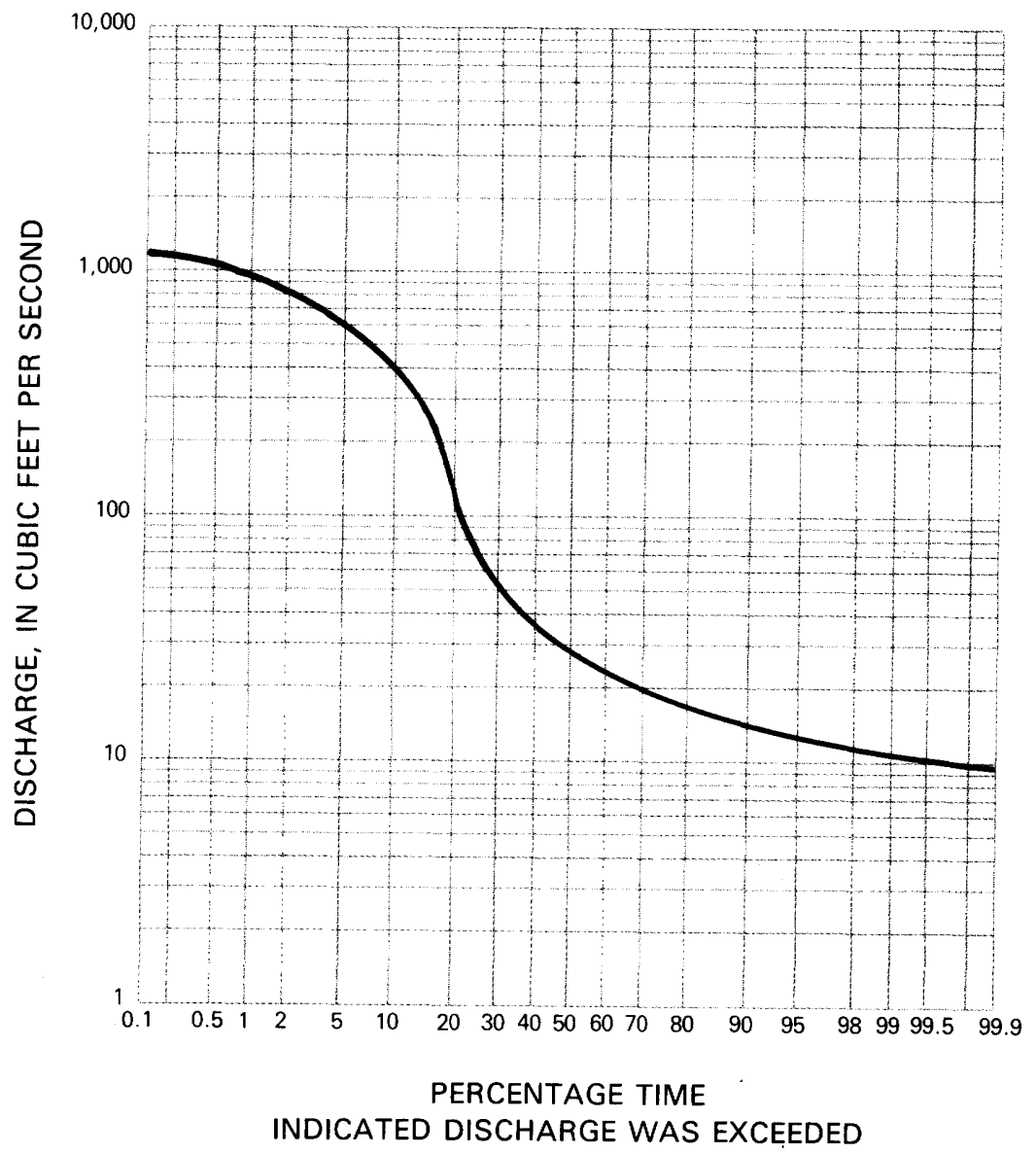



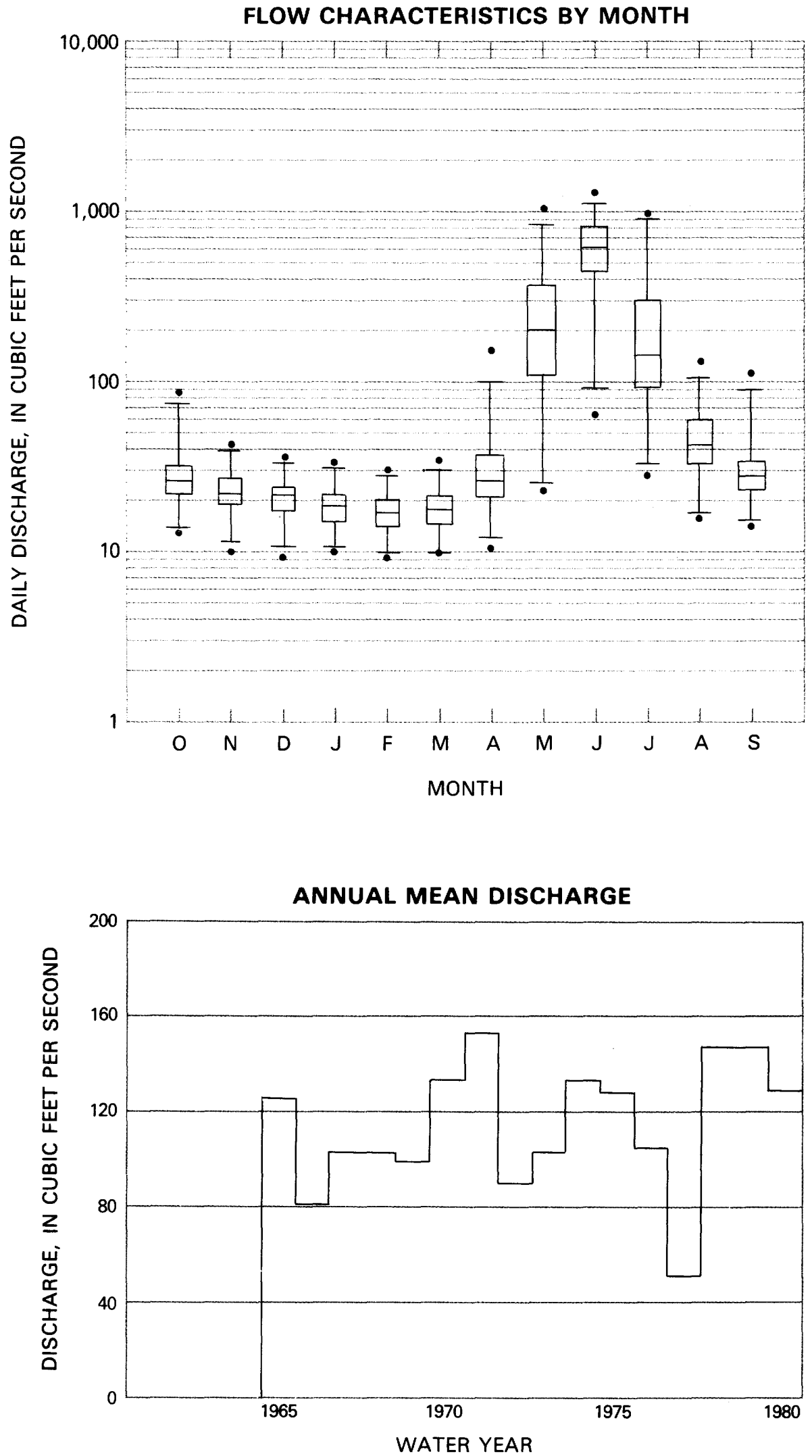

